University of Louisville

ThinkIR: The University of Louisville's Institutional Repository

Electronic Theses and Dissertations

$5-1997$

\title{
A program evaluation of the Louisville Enterprise Zone : a study of local planning and economic development.
}

Thomas E. Lambert 1959-

University of Louisville

Follow this and additional works at: https://ir.library.louisville.edu/etd

\section{Recommended Citation}

Lambert, Thomas E. 1959-, "A program evaluation of the Louisville Enterprise Zone : a study of local planning and economic development." (1997). Electronic Theses and Dissertations. Paper 788.

https://doi.org/10.18297/etd/788

This Doctoral Dissertation is brought to you for free and open access by ThinkIR: The University of Louisville's Institutional Repository. It has been accepted for inclusion in Electronic Theses and Dissertations by an authorized administrator of ThinkIR: The University of Louisville's Institutional Repository. This title appears here courtesy of the author, who has retained all other copyrights. For more information, please contact thinkir@louisville.edu. 
A PROGRAM EVALUATION OF THE LOUISVILLE ENTERPRISE ZONE A Study of Local Planning and Economic Development

\title{
BY
}

Thomas E. Lambert

B.A. University of Louisville, 1980

M.B.A., University of Louisville, 1986

M.S., University of Kentucky, 1993

\author{
A Dissertation \\ Submitted to the Faculty of the \\ Graduate School of the University of Louisville \\ in Partial Fulfillment of the Requirements \\ for the Degree of
}

Doctor of Philosophy
College of Business and Public Administration University of Louisville
Louisville, Kentucky


To the Graduate Council:

I am submitting herewith a dissertation written by Thomas $E$. Lambert entitled "A Program Evaluation of the Louisville Enterprise Zone." I have examined the final copy of this dissertation for form and content and recommend that it be accepted in partial fulfillment of the requirements for the degree of Doctor of Philosophy, with a major in Urban and Public Affairs.

Dr. Scott Cummings, Major Professor

We have read this dissertation

and recammend its acceptance:

Dr, Paul coomes

Dr. Thomas Lyons

Dr. John Nelson

Dr. Jay Vahaly

Accepted for the Council:

Dean of the Graduate School 


\section{DEDICATION}

This dissertation is dedicated to my mother, Doris E. Lambert, my brother, Gerald S. Lambert and to the memory of my father, Shirley R. Lambert (1922-1985). 


\section{ACKNOWLEDGMENTS}

The author wishes to thank Professors scott Cummings, Paul Coomes, John Nelson, Jay Vahaly, and Thomas Lyons for their support, patience and valuable consultation in the creation and completion of this document. I would also like to acknowledge the assistance of Dr. Ken Singleton who had already collected and compiled some of the data used in this paper. 


\section{ABSTRACT}

Multiple analytic methods are used to provide an analysis and evaluation of specific economic and neighborhood development policies undertaken by and continued by the Commonwealth of Kentucky, the City of Louisville, and Jefferson County since the early to mid-1980s. Such policies were initiated under the 1982 Kentucky Revised Statute 154.45 (KRS 154.45), which introduced enterprise zones to the Commonwealth and its urban areas. The policy goals of KRS 154.45 that are examined include: 1) the improvement of the quality of life of individuals that reside within the Louisville and Jefferson County Enterprise Zone (EZ); 2) the encouragement of economic activity through business formation, job creation, and job retention within the EZ; and 3) the elimination of blighted and deteriorated areas within the EZ. Several primary and general methods of analysis are utilized: direct comparisons of descriptive statistics, surveys, shift-share analysis, cost-benefit analysis and quasi-experimentation. The politics and history surrounding Louisville and Jefferson County's Enterprise Zone will also be discussed and examined. Political considerations appear to have played a key role in the evolution of the Ez program. The study shows that the EZ program cannot be considered a total success based upon the goals and objectives of KRS 154.45. It is estimated that nearly $\$ 218$ million in foregone tax revenues and fees were used to create jobs and investment 
that would probably have been generated regardless of incentives. In fact, job and investment growth in the $\mathrm{EZ}$ did not come close to the growth experienced in other parts of Jefferson County that did not have Ez incentives as well as to that experienced by Jefferson County as a whole during the same time period. This is true even when controlling for government incentives that may have existed in other parts of Jefferson County.

This study addresses the issues of local economic development policies and planning. A lack of planning and focus is identified as one reason why the EZ did not meet expectations. Other reasons why the EZ did not fully succeed will be discussed as well as possible alternative economic development programs that could have benefited the area targeted by the EZ program. 
I. Introduction and Overview . . . . . . . . . . 1

II. The Emergence of Enterprise Zones as an Urban Policy... . . . . . . . . . . . . . 6

1. Background . . . . . . . . . . . 6

2. The Rise of Supply-Side Politics and Economics, and the Emergence of Enterprise Zone Policy . . . . . . . . . 9

3. Critics of Enterprise Zone Policy . . . 15

4. The Performance of Enterprise Zones . . 22

III. A Narrative History of Louisville's Enterprise Zone

1. Louisville's Urban Problems. . . . . 33

2. Louisville's EZ: The Politics of EZ Development . . . . . . . . . . . 37

3. The Zone Comes under Scrutiny . . . . 50

4. Summary . . . . . . . . . . . . 56

IV. Methodologies for Evaluation . . . . . . . . . 59

1. Introduction . . . . . . . . . . . 59

2. Methods to be Used... . . . . . . . 62

3. Summary . . . . . . . . . . . . 72

V. Louisville EZ Performance Evaluation: Neighborhood Revitalization . . . . . . . . . . . . . 74

1. Overview . . . . . . . . . . . . . . 74

2. Evaluating Neighborhood Revitalization using Census Data . . . . . . . . . . 75

3. Evaluating Neighborhood Revitalization using Home Mortgage Disclosure Act Data . 89

4. Evaluating Neighborhood Revitalization using County Property Valuation Administration Records . . . . . . . . 93

5. Summary . . . . . . . . . . . 98

VI. Louisville Ez Performance Evaluation: Job Creation and Retention.................. 99

1. Overview . . . . . . . . . . . . . . 99

2. Job Creation in the Original EZ versus the County, 1980 to 1990 and 1981 to 1994 . . . . . . . . . . . . . . . . . 110

3. Job Creation in the Full-size EZ versus the County, 1980 to 1990 and 1981 to 1994 
4. Job Creation in the Airport area versus the County, 1980 to 1990 and 1981 to

1994 . . . . . . . . . . . . . . 125

5. Summary . . . . . . . . . . . . . 133

VII. Job Creation in Control and Comparison

Communities . . . . . . . . . . . . . 134

1. Job Creation in the Newburg Area versus

the County, 1980 to 1990 and 1981 to

1994 . . . . . . . . . . . . . . . . . . 134

2. Job Creation in the Jeffesontown-Bluegrass

Industrial Park Area versus the County,

1980 to 1990 and 1981 to 1994 . . . . 143

3. Summary . . . . . . . . . . . . 154

VIII. A Cost-Benefit Analysis of the EZ and an Analysis of How Well it Helped Disadvantaged Workers.................. 156

1. Introduction . . . . . . . . . . . 156

2. EZ Program Costs... . . . . . . . 158

3. EZ Program Benefits . . . . . . . . . 174

4. Caveats on EZ Job Creation and Retention as well as EZ Capital Investment . . . . 179

5. The EZ and Disadvantaged Workers . . . 187

6. Summary . . . . . . . . . . . . 189

IX. Conclusion . . . . . . . . . . . . . . . . 190

1. Review of Findings: Implications for Research, Theory, and Public Policy . . 190

2. Contributions of the Research to Economic Development Theory and Public Policy . . . . . . . . . . . . 197

BIBLIOGRAPHY • . . . . . . . . . . . . . . . . . 211

APPENDIX (cOPY of KRS 154.45). . . . . . . . . . 225

VITA . . . . . . . . . . . . . . . . . . 226 


\section{IIST OF TABIES}

TABLE

PAGE

1. Occupations . . . . . . . . . . . . 77

2. Housing Ownership Profiles. . . . . . . . 79

3. Housing Conditions . . . . . . . . . . . 81

4. Demographics and Education... . . . . . . 84

5. Unemployment Statistics . . . . . . . . . 86

6. Economic . . . . . . . . . . . . . 88

7. Shift-Share Analysis: Jefferson County and the United States Economy . . . . . . . . 101

8. National Growth Effect and Industry Mix Effect, Jefferson County, 1981 to 1994 ....... 102

9. Employment and Components of Employment Change, Jefferson County, 1981 to 1994 . . . . . . . 103

10. Shift-Share Analysis: Original EZ and Jefferson County, 1980 to 1990 . . . . . . . . . . . . . 111

11. Jefferson County Growth Effect and Industry Mix Effect, Original EZ, 1980 to 1990 . . . . . . . 112

12. Employment and Components of Employment Change, Original EZ, 1980 to 1990 . . . . . . . . . . 113

13. Shift-Share Analysis: Original EZ and Jefferson County, 1981 to 1994 . . . . . . . . . . . . . 115

14. Jefferson County Growth Effect and Industry Mix Effect, Original EZ, 1981 to 1994 . . . . . . 116

15. Employment and Components of Employment Change, Original EZ, 1981 to 1994 . . . . . . . . . . . 118

16. Shift-Share Analysis: Full-size Ez and Jefferson County, 1980 to 1990 . . . . . . 120

17. Jefferson County Growth Effect and Industry Mix Effect, Full-size EZ, 1980 to 1990 . . . . . 121

18. Employment and Components of Employment Change, Full-size EZ, 1980 to 1990 . . . . . . . . . 122

19. Shift-Share Analysis: Full-size Ez and Jefferson County, 1981 to 1994 . . . . . . 123 
20. Jefferson County Growth Effect and Industry

Mix Effect, Full-size EZ, 1981 to 1994. . . . 124

21. Employment and Components of Employment Change, Full-size EZ, 1981 to 1994 . . . . . . . . . . 125

22. Shift-Share Analysis: Airport and Jefferson County, 1980 to 1990 . . . . . . . . . . . 126

23. Jefferson County Growth Effect and Industry Mix Effect, Airport, 1980 to 1990 . . . . . . . . 127

24. Employment and Components of Employment Change, Airport, 1980 to 1990 . . . . . . . . . . . . 129

25. Shift-Share Analysis: Airport and Jefferson County, 1981 to 1994 . . . . . . . . . . . . . 130

26. Jefferson County Growth Effect and Industry Mix Effect, Airport, 1981 to 1994 . . . . . . . . 131

27. Employment and Components of Employment Change, Airport, 1981 to 1994 . . . . . . . . . . . . 132

28. Shift-Share Analysis: Newburg and Jefferson County, 1980 to 1990 ............ 136

29. Jefferson County Growth Effect and Industry Mix Effect, Newburg Area, 1980 to 1990 . . . . 136

30. Employment and Components of Employment Change, Newburg, 1980 to 1990 . . . . . . . . . . . . 137

31. Shift-Share Analysis: Newburg and Jefferson County, 1981 to 1994 . . . . . . . . . . . . . 139

32. Jefferson County Growth Effect and Industry Mix Effect, Newburg Area, 1981 to 1994 . . . . . 140

33. Employment and Components of Employment Change, Newburg, 1981 to 1994 . . . . . . . . . . 141

34. Shift-Share Analysis: Bluegrass Industrial Park Area and Jefferson County, 1980 to 1990 . . . 145

35. Jefferson County Growth Effect and Industry Mix Effect, Bluegrass Industrial Park Area, 1980 to 1990 . . . . . . . . . . . . . . 146

36. Employment and Components of Employment Change, Bluegrass Industrial Park Area, 1980 to 1990 . 147

37. Shift-Share Analysis: Bluegrass Industrial Park Area and Jefferson County, 1981 to 1994 . . . . 147 
38. Jefferson County Growth Effect and Industry Mix Effect, Bluegrass Industrial Park Area, 1981 to 1994 . . . . . . . . . . . . . . . 148

39. Employment and Components of Employment Change, Bluegrass Industrial Park Area, 1981 to 1994. 149

40. Estimated Taxes Lost to Capital Gains Exemptions... . . . . . . . . . . . . . 160

41. Estimated Net Operating Loss Carryforward . . . 161

42. Estimated Motor Vehicle Usage Taxes Foregone . 164

43. Estimated Sales Taxes Lost due to Exemptions on the Purchase of Building Materials, Equipment and Machinery... . . . . . . . . . . 166

44. Kentucky Economic Development Bonds used in the Enterprise Zone Area . . . . . . . . . . 167

45. Estimates of Building Permit Fees Foregone . . 169

46. Estimated Total Enterprise Zone Costs, 1983-96.171

47. Enterprise Zone Job Creation and Retention . . 174

48. Private Capital Investment . . . . . . . 178

49. USI Survey Results of 851 EZ certified firms . 180 


\section{IIST OF FIGURES}

FIGURE

PAGE

1. Original Enterprise Zone, 1983. . . . . . . . . . .41

2. Intermediate Enterprise Zone. . . . . . . . . . . .44

3. Current Enterprise Zone, 1986. . . . . . . . . . . 47

4. Enterprise Zone relative to Jefferson County. . . . .48

5. Lending as a Percentage of Total Loans. . . . . . .90

6. Growth Rates of Mortgage Lending. . . . . . . . . . .91

7. Ratio of Average Loan in Current EZ to Average Loan Amount in Other Areas. . . . . . . . . . . . . 92 


\section{CHAPTER I}

\section{Introduction and Overview}

This dissertation evaluates the efficacy of the Louisville and Jefferson County Enterprise Zone since its inception in 1983. No previous comprehensive evaluation of the Enterprise Zone (EZ hereafter) has been attempted despite the fact that the program is now over 13 years old. The importance of doing such an evaluation is critical because of the enormous potential costs and benefits of the $\mathrm{EZ}$ as a local economic development tool. The central questions that need to be addressed are whether the program achieved its stated goals, and whether the program had any other un-predicted or unanticipated effects on the local economy.

The EZ evaluation is important because of the continuing use of and emphasis on state and local initiatives to solve urban problems, and to encourage local economic growth. This is a trend that was started in the 1980 s and continues to this day. Despite the fact that the federal government has again become a partner in urban and community development through such initiatives as Empowerment zones and Enterprise Communities, these programs still leave much, if not most, of local economic development planning and promotion in the hands of local officials, with the federal government providing mostly financial assistance. This dissertation topic is a timely one because localities are still trying to generate solutions to their problems by promoting homegrown economic 
growth and prosperity in order to solve urban problems and to encourage local economic growth.

There have been previous evaluations of enterprise zones throughout the nation. This study is unique in that the Louisville and Jefferson County EZ is the largest in the nation, encompassing 45.7 square miles. In 1983, the zone originally only covered 3.75 square miles and was designed as an urban economic development program for disadvantaged and low income residents and the long-term unemployed. However, the zone grew twice over the next three years and took in many residential and commercial areas that would not normally have been considered distressed or economically depressed. Why the size of the zone was changed and why its focus changed will also be addressed in this dissertation because of the impact that such changes had on EZ goals as well as EZ benefits and costs.

This dissertation includes a narrative history of the EZ and will show the Ez's evolution in terms of both size and goals. National and local political and economic events preceding the birth of the EZ are examined. The history of the EZ shows the motivation for its origin and growth. Political factors are shown to be important in explaining the expansion of the EZ.

This study discusses the theoretical underpinnings of the Ez concept and the reasons why such programs were conceived and implemented. The frustration of national and local policy makers with traditional economic development 
programs is discussed along with the attractiveness of the $\mathrm{EZ}$ concept to those in the economic development community as a potential and viable alternative.

Since EZ programs and policies have varied from state to state and from locality to locality (there was not a national enterprise zone policy developed in the 1980s), no one program evaluation stands out as the definitive study of EZ success or failure. Around 37 states and the District of Columbia have, or have had, EZ programs. Since each jurisdiction has used a different mixture of tax and regulatory incentives in their EZs, a national study of the effectiveness of EZs has virtually been impossible because of a lack of comparability among state and local programs.

This dissertation cites and uses findings from previous EZ evaluations done throughout the nation. This is helpful since the dissertation takes a multi-method approach in evaluating the Louisville-Jefferson County EZ. There exists an abundance of literature on EZ evaluation that dates back to the early 1980s. Most evaluations take different approaches (surveys, shift-share analysis, cost-effectiveness analysis, etc.). All these methods are used to assess the performance of the Louisville-Jefferson County EZ.

A multi-method approach is used to provide a policy analysis and program evaluation of specific economic development policies undertaken and continued by the Commonwealth of Kentucky and Jefferson County, Kentucky since 1983. Such policies were initiated under the 1982 Kentucky 
Revised Statute 154.45 (KRS 154.45), and thereby introduced EZs to the Commonwealth's urban areas. The policies examined and evaluated include improvement of the quality of life of individuals that reside within Louisville and Jefferson County's EZ; encouragement of economic activity within the EZ; and elimination of blighted and deteriorated areas within the EZ .

The following methods of analysis are utilized to evaluate the success of EZ policy interventions: direct comparisons of descriptive statistics, survey results, shift-share analysis, cost-benefit analysis and quasi-experimentation. The politics and history surrounding Louisville and Jefferson County's Enterprise Zone is also discussed and examined. It is shown that political considerations played a key role in the development, evolution and implementation of Louisville's EZ program.

The evidence shows that the EZ program was at best marginally successful. It is estimated that nearly $\$ 218$ million in foregone tax revenues and fees were used to create jobs and investment that, for the most part, would probably have been generated regardless of incentives. In fact, job and investment growth in the EZ did not come close to the growth experienced in other parts of Jefferson County that did not have $\mathrm{EZ}$ incentives as well as to that experienced by Jefferson County as a whole during the same time period (1983 to the present).

The dissertation concludes with an analysis of local 
economic development policies and planning. Why the Ez has not been a full success will be discussed as well as possible alternative economic development programs that could have benefited the area targeted by the EZ program. The implications for future development policy are discussed. A central policy question that needs to be addressed is the efficacy of placing economic development into the hands of local government. Finally, recommendations for future research about EZs and their effectiveness is also discussed. 


\section{CHAPTER II}

\section{The Emergence of Enterprise Zones as an Urban Policy}

\section{Background}

There is an abundance of literature on the fate of U. S. cities after the end of World War II. The late $1940 \mathrm{~s}$ throughout the 1950 s saw people leaving neighborhoods that were close to central business districts in favor of newer neighborhoods and homes that were some distance from downtown areas. As post-war prosperity and government legislation (assisted by VA and FHA loans, and home mortgage interest tax deductions) encouraged a housing boom on the outskirts of most major cities, suburbanization swept across America.

With rising incomes, middle-class families could not only afford newer and larger housing, but also the automobiles that would allow them to travel back and forth to work. New federal and state highways as well as the beginning of the federal interstate system facilitated the suburbanite's ability to travel. Because location was critical to retailing success, shopping centers developed along the major thoroughfares of most new suburban areas.

At the same time, because of a growing economy, manufacturers needed more space in order to expand production. The horizontal layout of assembly-line work and mass production meant that larger parcels of land were needed. 
Such land was not readily available in the already developed inner cities. Plant expansion was often hindered and made impossible by a fixed and already built environment. On the other hand, the open and undeveloped land near suburban locations was ideal. The land was cheap, and many current employees had already moved into the outlying areas, or new employees could be recruited from nearby neighborhoods. What happened to cities during this time period? History points out that disinvestment on a deep and wide-scale basis occurred (Bluestone and Harrison, 1982; Ames, Brown, Callahan, Cummings, Smock, and Ziegler, 1992; and Wilson, 1966). With manufacturers, retailers, and residents leaving town, space and facilities that had at one time enjoyed extensive and intensive use now became abandoned and undesirable. With the exception of professional and technical jobs, many forms of work simply "disappeared" from the inner city and there began a spatial mismatch between available employment and those who wanted to work (Wilson, 1987, 1996). Those who could not afford new housing and those without transportation and/or certain skills and education would be left behind in quickly deteriorating neighborhoods (Wilson, 1987). Particularly hard-hit by these trends were minorities, especially African-Americans.

The fiscal coffers of America's cities were also hardhit. As more and more property owners left the city for unincorporated areas around the city, property tax revenues began to decline (Mikesell, 1982; Stiglitz, 1988; and Rosen, 
1992, pp. 543-545). The property tax had always been the backbone of municipal finance. As the revenues shrank, so did the ability of cities to finance day-to-day operations and services as well as big ticket projects such as infrastructure improvements, maintenance and replacement.

In an attempt to remedy this situation, urban renewal was started during the Eisenhower Administration. Deteriorated neighborhoods with dilapidated housing were replaced with new public housing facilities and roadways that connected the inner city to interstate highways (Ames, et al, 1992). Throughout the 1950 s and 1960s, one blighted neighborhood after another succumbed to massive rebuilding projects that completely changed the urban landscape for better or worse (Anderson, 1964). Yet poverty still remained a problem in America's urban areas.

In the 1960s and 1970s, the federal government tried to rehabilitate ailing cities through President Johnson's Great Society programs and President Nixon's New Federalism. The expansion of the social safety net for the poor and the elderly as well as federal revenue sharing were basically redistribution programs aimed at providing relief for urban poverty and their symptomatic problems-crime, crumbling infrastructure, etc. There were also attempts to provide job training for inner city residents through the Comprehensive Employment Training Act (CETA). Presidents Ford and Carter pretty much continued and maintained these policies despite increasing political pressure for federal fiscal restraint. 
The amelioration of economic hardship along with increasing

the skills of urban residents were seen as a two-pronged

strategy for revitalizing cities and their neighborhoods.

However, despite the support for various urban programs throughout the 1950s, $1960 \mathrm{~s}$ and 1970s, there were many critics of American urban policy during this time period. These critics spanned the political and ideological spectrum. They observed that, despite best efforts, cities were still filled with pockets of poverty and high unemployment. In fact, some claimed that a new "underclass" had developed within America's urban areas (Wilson, 1987). Most of all, according to Ames, et al (1992):

Community development programs, many contended, were implemented in an uncoordinated and sporadic manner. In the face of long-term urban development trends, neither the Community Development Block Grant program nor Urban Development Action Grant funds could alter the growing polarization between city and suburb. Nor could they reverse the outward migration of people and capital to the suburbs. Federal revitalization programs were poorly conceived in Washington, badly coordinated between various governmental jurisdictions, and inadequately monitored at the local level (Pressman and Wildavsky, 1980). Funds often were spent on questionable projects or maneuvered into programs not initially authorized by federal legislation (Tabb and Sawers, 1978). (p. 208).

\section{The Rise of Supply-Side Politics and Economics, and the Emergence of Enterprise Zone Policy}

During the 1970s, many local and national American

leaders were challenged by gloomy economic conditions:

periods of high unemployment and high inflation. Along with

the continuing problems of urban areas, many leaders felt that 
something new had to be tried in order to solve declining U.S. economic growth, especially declining growth in American cities. It was believed by many that previous government programs had failed to revive both national as well as local economic vitality and that new policies were in order. The 1980 elections seemed to confirm these sentiments as conservative Republicans captured the White House and the U.S. Senate.

The 1970s saw Keynesian and activist government policies fall into disfavor. The federal government was seen as the cause of U. S. economic problems, not the solution (Friedman, 1962; Feldstein, 1969 and 1977; and Laffer, 1979). This view was also held by those who were critical of federal efforts to help cities and the poor (Anderson, 1964; and Murray, 1984).

Like the U. S., Great Britain was also experiencing economic hardship, especially in its older, urban centers. In the late 1970s, under the Thatcher regime, an attempt to revive urban economic growth was already underway. A British planner, Peter Hall, put forth the idea that perhaps the only way to revitalize deteriorating urban areas and to reduce urban unemployment was to create urban "enterprise zones" (Hall, 1977). An urban enterprise zone would be a specific, targeted area within a city where businesses would be exempt from many taxes and regulations--"freeports" (Hall, 1977) of trade in the inner city. In theory, these zones would be attractive to new firms because the costs of doing business 
would be greatly reduced. ${ }^{1}$ According to Hall, much of the success of Pacific-Rim countries such as Hong Kong, Singapore and Malaysia was due to the fact that such nations had low taxes and little business regulation. The solution to urban stagnation and decline was not more government programs, but fewer government programs and less government interference in both business and local government decision making. However, Hall did warn that such policies should only be relied upon as a last resort (Hall, 1977).

Hall was well aware that what was applicable to far eastern nations may not be applicable to western nations whose people had experienced unionization and some form of welfare state. Advanced industrial nations had already gone through the extreme laissez faire conditions of the 19 th century that now existed in 20 th century Asian miracle economies. However, because many inner city residents lacked the skills and training for newly emerging high-tech and service jobs, Hall's ideas did not seem too far-fetched to many economists and politicians. After all, many of the developing economies of the far east had an ample number of low to un-skilled workers. Urban areas were desperate to replace employers who had moved to suburbia (Hall, 1982). Given the severely depressed level of economic activity of the inner city, Hall felt it unfeasible for cities to attempt economic development that required a lot of high technology, such as

1 It should be noted that Hall had some initial reservations about his ideas. He later declared the implementation of his theory to be insufficient for urban regeneration. 
science based industries and research and development facilities. The costs of retraining un-skilled and low-skilled inner city residents also seemed prohibitive given the fiscal constraints that faced national, state and local governments. On-the-job training done by the private sector, however, was feasible if businesses were given the right incentives to provide it.

Hall (1982) envisioned the enterprise zone concept as one way of possibly bringing inner-city residents into the new world of technical jobs. If taxes, tariffs, and government regulation were removed from an area, entrepreneurs would invest there. The first employers to invest in the EZs would need the services of un-skilled workers. One obstacle to hiring such workers would be the minimum wage, so therefore, these freeports would have to be exempt from minimum wage laws. The removal of the minimum wage would also make it much cheaper to train these workers.

Hall's ideas were adopted by many British economic development advocates who saw his proposal as an alternative to the urban policies of that time period. The British experiment with EZs also did not go unnoticed by U. S. proponents of supply-side economics. Even before Ronald Reagan's election to the presidency, proposals for U. S. urban enterprise zones had been introduced in the Congress (Butler, 1991). The newly elected President made enterprise zones his major, if not his only, urban initiative. Traditional urban 
programs, such as revenue sharing, Community Development Block Grants (CDBGs) and Urban Development Action Grants (UDAGs) would either be dramatically curtailed or eliminated. Other programs that affected urban constituencies--summer jobs for youth, welfare and food stamps--were also targeted for dramatic spending reductions. Enterprise zones would then have to provide employment and new sources of local government revenues in order to mitigate the decline of federal programs $(\mathrm{Tabb}, 1984)$.

Despite achieving victories in rolling back the role of the federal government in urban areas, the Reagan Administration was unsuccessful in getting a federal enterprise zone program approved by the Congress. Much of the resistance was based upon doubts about how effective such a program would be and about how much it would cost the federal government in lost tax revenues. The federal budget deficit had increased dramatically after the 1981 tax cuts and the 1981-82 recession. More importantly the fairness of the program was questioned by Democrats and moderate Republicans since the Administration proposed either abolishing the minimum wage or creating a sub-minimum wage in the zones so as to make labor cheaper and more attractive to employers. Congress and the public were not ready for such proposals (Tabb, 1984).

Despite critics and reservations, Britain's experiment with EZs would soon be imported into the U. S. Given the severity of the 1981-82 recession (the worse since the Great 
Depression (Ruffin and Gregory, 1994, p. 104)) and the inability of the Reagan administration to enact a national enterprise zone policy, many states decided that something had to be done to stem the decline of their urban areas. The 1980s, whether by design or by default, saw the federal government become more and more disengaged from urban policy. Federal tax cuts, an increase in military expenditures and business deregulation became the central pieces of the Reagan administration's macroeconomic policies. But as far as local and regional policies were concerned there were really none in existence (Ames, et al, 1992; Gaffikin and Warf, 1993).

Because the Reagan enterprise zone proposals were never enacted, many state governments decided to take independent initiative on the enterprise zone concept. With the nation suffering a severe recession in 1981 and 1982, and with some states not yet fully recovering from the recession's aftermath, the 1980s saw many states trying to solve their own economic and urban problems. Since Washington had decided to play a smaller role in local economic development and public welfare (Ames, et al, 1992; Gaffikin and Warf, 1993; and Tabb, 1984) most states decided to undertake these tasks. By 1988, over 37 states and the District of Columbia had implemented some form of an enterprise zone program. Many states had multiple EZ locations. EZ incentives varied widely across and within these states (Green, 1991). 


\section{Critics of Enterprise Zone Policy}

Despite widespread implementation, the political and economic criticisms of the EZ concept, both in the U. K. and the U. S., were many. The biggest issue was whether development incentives would be effective in arresting and reversing urban decay. Proponents of EZs argued that such development incentives were necessary to encourage investment in areas perceived as poor risks (Hall, 1977, 1982; Butler, 1981, 1992; U. S. Chamber of Commerce 1981; Kemp 1982, 1989, 1992; Weiner 1984; Congressional Digest 1985; and Cowden, 1992). However, even Hall (1982) admitted that deregulation, low taxes and low wages would not by themselves solve urban unemployment and underemployment. Some type of public reinvestment in blighted communities would also be necessary to make EZs work (Gunther and Leathers, 1987).

Additionally, other critics pointed out, Ezs would not necessarily attract high-tech industries. If Hall had fashioned his model after emerging Asian economies, why would sweatshops or other exploitative economic arrangements that developed in these economies not arise in the inner cities of the U. S. and Europe as well (Harrison, 1982)? In other words, what guarantees were there that companies locating in an EZ would be high-tech? What if EZs only attracted low-tech, low-wage, dead-end jobs?

Also there was the potential problem of EZs creating a zero-sum competitive climate among EZ-designated areas as well 
as EZ versus non-EZ designated areas (Peirce, Hagstrom and Steinbach, 1979; Clarke, 1982; Massey, 1982; and Blair, 1995, pp. 174-181). That is, EZs could lead to the spatial redistribution of existing jobs from one $\mathrm{EZ}$ to another or from a non-EZ region to an EZ-designated area rather than create new jobs and businesses. EZs could place companies outside of the designated area at a competitive disadvantage compared to firms in the area through lower costs of production (cheaper labor, tax breaks for capital investment, etc.). Firms that found themselves in direct competition with EZ firms could decide to relocate into an EZ that offered them less regulation and lower taxes than the jurisdiction in which they were currently located. Or a firm in an existing Ez could still move to another EZ if the latter promised even better tax incentives and deregulation for business firms.

The possible migration of firms could be from either one location in a city to another location that had EZ status in the same city, or firms could migrate into the Ez from even greater distances. Either way, although there could be the potential for the creation of new jobs in an EZ, the potential for the redistribution of existing jobs seemed to be stronger because of cut-throat competition among regions (Massey, 1982). As O'Sullivan (1993, pp. 68-69) and Bartik (1991) point out, most new jobs created in metropolitan areas are filled by newcomers to the region. Therefore, if new job creation did occur, there could be no guarantee that the people for whom the EZ was to benefit would actually be helped 
in finding employment.

Another group of critics seriously questioned whether incentives such as tax and regulatory relief would have any impact at all on investment or business location decisions, as well as job creation and retention efforts (Harrison and Kanter, 1978; Peirce, Hagstrom and Steinbach, 1979; Vaughn, 1979; Jacobs and Wasylenko, 1981; Schmenner 1982; Hawkins, 1984; Rubin and Zorn, 1985). These critics argued that the limited savings provided by incentives were too small in proportion to the overall costs of a firm in order for them to affect employment and investment decisions. According to this line of thought, those jobs that would be created by EZs would probably be low-paying and provide little job security (Clarke, 1982; and Goldsmith, 1982).

Another school of thought on EZs focused upon the direct and indirect costs associated with them. It is argued that their incentives in the form of foregone tax revenues and possibly more public capital spending increase the tax burdens for nonzone firms and residents by shifting these higher tax burdens onto the non-EZ firms and residents (Armstrong, 1981; Humberger, 1981; Mounts, 1981; Clarke, 1982; and Hawkins, 1984). Also, according to critics, the zones might only tend to transfer capital investment from one location to another, rather than creating new investment (Peirce, Hagstrom and Steinbach, 1979; Clarke, 1982; Massey, 1982; and Blair, 1995, pp. 174-181). Finally, some critics argued that Ezs indirectly lower government aid in distressed communities, and 
that more resources, not less, should be focused on programs such as education and job training for urban residents (Birdsong, 1989; Estes and Hamond, 1992; and Levitan and Miller, 1992).

Additionally, political and economic arguments for and against EZs were developed by critics centering around the appropriate roles of the federal, state and local governments. Public choice advocates generally argued that local jurisdictions, not the federal government, should be the driving force behind local economic development and quality of life issues (Buchanan, 1960 and 1965; Tiebout, 1956; Butler 1991; and Peterson, 1981). Federal programs that focused on redistribution policies (e.g., UDAGS, CDBGS, and revenue sharing) were seen as encouraging cities and other underdeveloped regions not to change. That is, similar to conservative arguments made against AFDC, food stamps and other forms of welfare to individuals and families, these programs did nothing to encourage localities to become selfsufficient. If anything, these programs were seen as encouraging cities not to promote economic development and revitalization.

The alternative was to either cut back or end these programs, and by doing so, promote competition among localities and regions. A competitive environment among local jurisdictions, just as with a perfectly competitive environment among business firms, would make cities stronger and more self-reliant. Otherwise, cities that did not strive 
to better themselves and "pull themselves up by the bootstraps" would wither away. According to this logic, by competing against each other, state and local governments would be forced to offer the appropriate levels of taxation and services necessary to promote economic growth and a high quality of life for their residents. Local governments that failed to satisfy local constituents--residents and businesses alike--might suffer the consequences of constituents "voting with their feet" and moving to another jurisdiction within the same region. No longer would the federal government subsidize city and local government spending. Local governments would be forced to offer better services at lower costs (due to having to lower their taxes) if they wanted to attract capital and to bring back middle class residents. Cities would have to become leaner yet stronger when it came to fiscal and service delivery matters. Lastly, it was believed that local officials could better handle economic redevelopment because they were in more direct contact with their constituencies than the federal government. It is easy then to see how Ezs could become the tools of local governments trying to enhance their competitive advantage vis a vis other local governments. In an age of federal fiscal austerity, the public choice view became an attractive philosophy.

Nevertheless, there are still many who believe that exclusively putting economic development into the hands of local governments is still a bad idea and that the national government can still best pursue policies that are in the 
interests of distressed urban and rural areas (Ladd and Doolittle, 1982; and Gaffikin and Warf, 1993).

Counter to public choice ideas, many advocates took the view that economic development and economic growth for depressed regions (whether urban or rural) is and always should be a task for the federal government. According to the advocates of an activist federal government role, the historical record of local governments trying to encourage economic development and trying to help depressed and impoverished areas was always substandard at best (Musgrave, 1959, pp. 181-182; Oates, 1977; and Hughes and Cain, Ch. 25, 1994). Even some public choice advocates admitted that it was not in the best interests of state and local governments to help their poor (Peterson, 1981). It was for this reason (and others) that President Roosevelt's New Deal policies put regional economic development and poverty relief into the hands of the federal government (Brock, 1988; Spulber, 1989; and Stein, 1996). In an advanced industrial society, state and local governments did not have the power, information, capacity and in many cases the inclination to plan and produce a national economic recovery much less the capability to improve their most impoverished areas (Musgrave, 1959; Oates, 1977; Galbraith, 1976; Schlesinger, Jr., 1958, Ch. 16; Stiglitz, 1988; Ladd and Doolittle, 1982; Gaffikin and Warf, 1993) .

At the heart of federal activist policies was the influence of Keynesian economics. John Maynard Keynes (1936) 
believed that economic growth and prosperity could best be achieved by national economic policies. It was felt by Keynes and other "Keynesians" (Musgrave, 1959; Heller, 1966; Hicks, 1967; Solow, 1970; Samuelson, 1975; and Okun, 1981) that the national government could stabilize the extreme "ups and downs" of the national business cycle as well as provide assistance to those areas of the nation that were structurally depressed (e.g., the Tennessee Valley Authority, the Works Program Administration, etc.) either through direct federal programs or federal grants. Local governments would have input on local economic development, but the federal government would provide leadership.

Those who held the belief that the federal government should be the leader in assisting underdeveloped cities and regions argued that EZ programs would lead to zero-sum competition among localities (Bluestone and Harrison, 1982; and Harrison, 1982). Jurisdictions that were already poor to begin with could not compete against wealthier ones no matter how many incentives the poorer areas offered to potential new residents and businesses. Besides, these jurisdictions had very little money to offer substantive incentives anyway. Wealthier localities would continue to become wealthier while poorer areas would continue to become poorer. It was also argued that many families and businesses made location decisions based on more than just tax considerations. The EZ experiment was seen as a band-aid approach for cities that needed intensive care because of their critical condition 
(Massey, 1982).

On a different front, some argued that it has never been, and never should be, the job of local government to be in the arena of economic development. Instead, according to some legal scholars (Rubin, 1993 and 1994), from a legal and constitutional point of view, it has been the duty of states and municipalities to offer basic government services (police protection, sanitation, schooling, etc.) and not to embark on what some policy critics label "smokestack-chasing" and industry recruitment activities. Such activities do not meet the legal criteria of either a public purpose or public benefit. That is to say, tax dollars paid at the local level have always been, from a traditional legal point of view, solely for the purpose of carrying out basic and essential public services--no more, no less.

\section{The Performance of Enterprise Zones}

In light of various criticisms of EZ policy, numerous evaluations of their performance have been initiated. Generally, the literature on U. S. EZs seems to show wide variation as to whether EZs are successful (Rubin and Wilder, 1996). The growth in employment and capital investment due to

EZs shows a record of uneven performance. Among the most important issues in the evaluation literature is whether increases in the number of jobs created or retained as well as the capital formation that takes place in an EZ can be 
ascribed to the incentives offered to companies located within them or to companies considering the move into an EZ. Unfortunately, the literature does not have as much to say about the evaluation of EZs when it comes to private business and capital formation as it does with regard to employment (Rubin and Wilder, 1996). Incentives that encourage capital formation are not as carefully scrutinized as those that are supposed to promote job creation. Perhaps this is because it is assumed by EZ proponents that capital formation leads to job creation. Therefore, evaluating the ability of Ezs to create jobs becomes an indirect way of evaluating capital formation (Rubin and Wilder, 1996). That is, if an EZ program was successful in creating or retaining jobs, then it must have been successful in creating or retaining capital in a targeted area.

With regard to job creation, the provisions of the Maryland statewide enterprise program, examined over the 1983 to 1984 period, were not seen as helpful to businesses hiring new employees. Because of the way the Maryland state enterprise zone was written, there was a two year time delay between the reporting of a business income tax credit for hiring a new employee and the business receiving the tax credit (Funkhouser and Lorenz, 1987, p. 68). This made the tax credit pretty much ineffective when it came to job creation. Moreover, the authors found that few workers remained on the job permanently and that the cost per job created was approximately $\$ 57,000$ (Funkhouser and Lorenz, 
1987, p. 75).

In the same way, Dabney (1989, p. 135) found that financial incentives in the Texas EZ program had very little impact on job creation because the incentives did not address the most important concerns of firms: transportation, insurance, and access to raw materials. Any decrease in costs from the EZs was offset by an increase in the costs of these factors. Other research measures changes in employment through the number of unemployment claims or the unemployment rate. Some research indicates that enterprise zones actually lower unemployment in EZ designated areas. Papke (1994) found that the business income tax credit incentive for hiring new employees decreased the number of unemployment claims 19\%, or 1500 claims, in Indiana over the 1981 to 1989 period. Also, Sridhar (1996) found that Illinois' EZ program helped to reduce unemployment in moderate and high unemployment areas in most EZ designated areas.

However, another article by Papke (1993) that compared enterprise zones to similar non-enterprise zone control areas found virtually no difference in changes in the unemployment rates among the areas. Data were presented on the differences between zones (15) and non-zones (24) through an analysis of 1980 and 1990 Census block group data. Though there was an improvement in zones compared to non-zones with regard to unemployment, the differences were very small. Rubin and Wilder (1989) utilized the method of shift-share analysis in order to assess the effectiveness of 
Evansville's (Indiana) Ez program in creating new jobs. Their study found that of the 1,430 jobs created in Evansville over the 1983-1986 period, only 327 would not have been created without the enterprise zone. However, the authors note that the remaining 1,193 jobs would have probably been created somewhere in the Evansville metro area anyway, but not in the enterprise zone. Shift-share analysis is a tool which has limitations, and these limits, as well as shift-share's pluses, will be discussed later in the dissertation because it is used in analyzing Louisville and Jefferson County's Ez. An econometric study of EZs in Indiana (Seyfried 1990) similarly found that the incentive packages of EZs had very little impact on employment. Seyfried found that the elasticity of employment with respect to the tax credits of EZs is highly inelastic, and hence have little impact on job creation.

Two studies provide an analysis of the impact of EZs on employment growth across the U. S. (O'Huallachain and Satterthwaite, 1992; Glover 1993). Examining 100 EZs across the country, Glover (1993, p. 98) found that Ezs created or retained an average of 559 jobs per zone. In an examination of job growth in some 264 MSAs over the 1977 to 1984 period, O'Huallachain and Satterthwaite found that the presence of EZs had very, very little impact on job growth. Instead, results indicated that localization economies, urbanization, and local labor market conditions (how skilled is the local labor force) are the most important determinants of job growth. 
One study that sought to isolate the impact of EZs by asking businesses the primary or exclusive reason for their new location or expansion decisions found mediocre results (Rubin 1990). In an examination of New Jersey EZs over the 1987 to 1988 period, Rubin found that 3,948 jobs were created because of the characteristics of the EZs. This was at a total cost of $\$ 51.6$ million, or $\$ 13,070$ per job. The cost-effectiveness of this was that $\$ 0.70$ "was generated in New Jersey state and local taxes for every $\$ 1.00 "$ in EZ incentives received. However, the study was done for an entire state, and in addition to business income tax credits, EZ incentives included a rebate on unemployment insurance taxes.

Sridhar's (1996) study of Illinois EZs found that program costs were greatly outweighed by program benefits. Using a concept of a "reservation wage" for unemployed workers, she found that even in cases where EZs had caused firms to relocate from one locality to another (rather than cause new firms to open in the EZ), tax incentive costs were small in comparison to the net benefits yielded by Ez economic development and job creation. However, Sridhar's strict set of assumptions could be said to bias her conclusions. One of her assumptions is "[I]t is assumed that employment generated in these zones is attributable to zone incentives. There is also an assumption that jobs created in such zones will be filled by the local unemployed, primarily to justify local expenditure" (Sridhar, 1996, p. 70). Sridhar, therefore, 
automatically assumes that all zone incentives would have a direct and positive impact upon employment and investment.

An empirical study of Indiana's EZs showed that the largest increase in jobs occurred in services, retailing, wholesaling, finance, insurance and real estate and transportation (Papke, 1993). So far this is the only U. S. study of the effects that $\mathrm{EZ}$ incentives have on types of employment. Papke noted that during the course of his research, manufacturing employment declined considerably while employment in these other sectors rose (as was the case throughout most of the U.S. during the 1980s). Despite the fact that many proponents of EZs saw the programs as leading to the revitalization of manufacturing within inner cities, Indiana's EZ programs do not seem to have stemmed the decline of manufacturing in the state.

Rubin and wilder (1989) found that the largest increases in employment in the Evansville, Indiana EZ were in transportation, wholesaling, retailing and services. There was a decline or stagnation in each of eight categories of manufacturing. One common element among the sectors with the greatest growth was the "presence of generally high levels of finished product inventories" (Rubin and Wilder, 1989, p. 422). Since the biggest incentive in the Evansville Ez program was an inventory tax credit, this is not surprising. In fact, much of the job growth in the zone was attributed to the opening of a new warehouse and distribution center. More recently, Dowall (1996) found that most of 
California's 13 Enterprise Zone programs did not even come close to producing the jobs that state development officials had hoped for. Instead, most of the 13 EZs suffered job losses between 1986 and 1990 even when controlling for national and industry-specific economic trends. Dowall's method of using County Business Patterns data at the zip code level was useful in his analysis and will be used in this dissertation to assess the Louisville EZ. Further elaboration on this method will be provided in a later chapter.

What very little research there has been on EZs with regard to capital formation, creation and/or retention seems to be focused on whether EZs cause firms to relocate from one area to another because of $\mathrm{EZ}$ incentives. As mentioned earlier, opponents of the EZ concept argue that EZs will simply relocate businesses, either from within or outside a local region with no new business expansion, in a zero-sum manner. An EZ located in one part of a city, it is argued, will simply attract capital and jobs away from other parts of the city. There does seem to be some empirical evidence on the impact of EZs in Great Britain that support this argument (Bromley and Rees, 1988; Bromley and Morgan, 1985; Talbott, 1988). According to this evidence, about half of the jobs created were the result of relocation. However, relocation seemed to occur more because of abundant and cheap commercial real estate in the zone area than because of financial incentives. Bartik (1991) also shows that firms in the U. S. are less sensitive to the costs of intra-metropolitan 
movements than to the costs of inter-metropolitan movements, thereby giving some credence to the relocation argument.

Many critics (Jacobs and Wasylenko, 1981; Clarke, 1982; Mier, 1982; Walton, 1982; Glickman, 1984; and Hawkins, 1984) have argued that EZs would favor capital formation over job creation, and that the biggest winners with regard to EZ incentives would be large, national and/or multinational firms with few loyalties to local communities. Yet Erickson and Friedman (1991) found that in 35 states EZs helped to create many new jobs by encouraging the start-up and growth of many small, newly formed, businesses. Very few firms in their study were large, capital-intensive establishments that had located from outside of the zone because of zone incentives. Jones (1985 and 1987) compared the number of property transfers and building permits issued within the Bridgeport, Connecticut and Decatur, Illinois EZs to those in similar but non-Ez areas and found either marginal differences in transfer and building activities between the EZ and non-EZ areas or found that differences could easily be explained due to factors other than EZ incentives.

In 1986, the U. S. Department of Housing and Urban Development (HUD) conducted interviews with over 200 state and local officials in an effort to gauge $E Z$ effects on communities in nine states. Survey results revealed that 263 E2 firms were deemed to be responsible for the creation or retention of 7,348 jobs and over $\$ 147$ million in new investment by new and expanding firms. EZ incentives had some 
influence on the expansion decisions of existing firms, but played less of a role in the location decisions of new firms. However, HUD declared that it had had difficulty in getting good data on EZ impact effects and concluded that the study's outcomes for jobs and investment could not be attributed solely to EZ incentives. Critics of the HUD study also maintain that simply relying upon interviews with state and local officials who have a vested interest in EZ successes potentially biased and diminished the results of the HUD report. Incidentally, one of the zones examined was Louisville's EZ.

A 1985 study done by the state of Connecticut (done independently of Jones (1985)) claimed that in addition to 4,300 new jobs created and 4,200 jobs retained due to the state's $6 \mathrm{EZ}$ areas, over $\$ 113 \mathrm{million}$ in new investment was brought into the Ezs through mostly existing firms.

Nelson and Whelan (1988) found through surveying firms that Louisiana's EZs were supposed to have created $\$ 27.4$ million in investment and 1,036 new jobs. In contrast to previous studies, the majority of respondents said that incentives were more important in location decisions than in expansion or new capital investment decisions. However, only 19 firms participated in the survey. Erickson, Friedman and McCluskey (1989) used data from the 1986 HUD study and found that in 357 zones across 17 states, EZs created an average of 333 new jobs and $\$ 23.4$ million in new investment per zone. This was done mostly by new or existing firms. Also, Rubin 
and Armstrong (1989) did a survey of EZ firms in 10 New Jersey zones that claimed that 9,193 jobs had been created in the zones between 1985 to 1988 and that $\$ 803$ million of new investment had taken place during the same time period. The majority of the 478 New Jersey firms surveyed said that incentives had influenced location or expansion decisions (approximately $70 \%$ ).

Litster (1990) did a survey of California businesses in EZs from 1986 to 1988. Of the 137 firms surveyed, Litster estimated that 2,518 new jobs were created and that $54 \%$ of the new jobs created were generated by new, start-up businesses. However, $55 \%$ of business owners did not regard incentives as important in making location decisions. Two years later, a report released by the Indiana Department of Commerce showed that from 1989 to 1990, 12 Indiana EZs created 2,024 new jobs and generated $\$ 199$ million in investment and $\$ 272$ million in new state and local tax revenues for only $\$ 20.6$ million in program costs (Rubin, Brooks, and Buxbaum, 1992).

Overall, studies of $\mathrm{EZ}$ incentives with regard to job creation or retention and capital formation and movement appear incomplete and often contradictory. As Rubin and Wilder (1996) write in regard to the effectiveness of most EZs:

...[P] rogram experience has made two realities clear: enterprise zones have not lived up to the broad panacea-like imagery conjured up by early federal proposals and rhetoric.; neither, however, have they brought about the massive dislocations and dominance of large industries predicted by enterprise zone critics. The answer to the enterprise zone riddle is far 
more complex than either its promoters or detractors suggest. (pp. 473-474).

The authors believe that the conflicting evaluations of EZ efficacy is due to the poor planning and oversight that most states have done in creating and implementing EZs. That is, because state and local governments often failed a priori to specify Ez goals and objectives as well as to put together data bases to monitor the progress of EZs, it is not surprising to find studies that when taken as a whole are contradictory and inconclusive.

Kentucky's experience with EZs is similar to those of other states. The history of the Louisville zone is examined in the following chapter. Political issues and controversies affected the design and implementation of the Louisville EZ and significantly affected its overall impact on the local economy. 


\section{CHAPTER III}

\section{A Narrative History of Louisville's Enterprise Zone}

\section{Louisville's Urban Problems}

Prior to the national economic problems of the 1970 s and 1980s, the Louisville area's economy was very robust. Like many other metro areas in its region of the country, Louisville and its home county, Jefferson, had a high concentration of jobs in manufacturing. In fact, Louisville probably had a higher than the national average percentage of jobs concentrated in manufacturing--25 to $33 \%$ locally compared to the nation's 22\% (Massey, 1985). Most of these jobs were high paying and required very few skills. A few manufacturers were very large employers--General Electric's Appliance Park, Ford Motor Company's two vehicle assembly plants as well as International Harvester. In fact, during the early 1970s, General Electric at one time had over 22,000 employees (Ward, 1996). It now only employs approximately 7,000 workers.

But there were also deep underlying problems that were developing during these times. The city and Jefferson county had many residents who were labor union members. Because of frequent "wildcat strikes" (those not authorized by national union headquarters) and because of continuous labor-management conflicts, Louisville and Jefferson County became labeled "Striketown USA," a nickname that stuck for quite some time 
(Koebel and Remington, 1988). Because unions were so prevalent in the area, many existing businesses either did not expand or left town. Many potential new businesses, especially manufacturers like Toyota, decided against locating in Louisville because of its reputation as a strike-prone city (Shafer, 1985).

There were also tensions between the city and the county. These tensions were not just between the leaders of each government, but among the people of each jurisdiction. During the late 1950 s and 1960s, western Louisville experienced a massive amount of "white flight" with many residents moving out of the city and into various parts of the county. According to Cummings and Price (1990, p. 6), the percentage of Louisville residents who were African American remained fairly static from 1870 to 1950. Then from 1950 to 1980, the percentage of blacks living in the city grew from $15.6 \%$ to $28.2 \%$ as the population of the city declined from 390,639 in 1960 to 298,451 in 1980 . Also from 1950 to 1960, the percentage of whites living in the City of Louisville fell from $84.3 \%$ to $71.1 \%$ whereas Jefferson County outside of Louisville's boundaries saw its population increase from 220,308 in 1960 to 386,553 in 1980 (Cummings and Price, 1990, p. 9). During this time, one reason why the city's minority population went up percentage wise as well as numerically was because of the migration of Southern blacks into the community who had hopes of finding better job opportunities. Such was the case in many "border" states and Midwestern states during 
this period (Hughes and Cain, 1994, Ch. 29). Later in 1975, racial hostilities exploded with the advent of forced busing throughout Jefferson County.

Around the same time that racial realignments were occurring within the city and county, many businesses left the city in favor of other locations in the region. New suburbs and small incorporated cities also began to proliferate in the county. Large, new suburban shopping centers, industrial parks and office complexes developed in Jefferson county. These developments took income and sources of capital away from many downtown Louisville businesses.

With many middle and upper income whites leaving the city and taking their business elsewhere, the city's fiscal health began to suffer. Meanwhile, Louisville's minority population could not find enough jobs, partially because of discrimination and because many businesses were leaving the city just at the time that the minority population was increasing. Since many blacks who had migrated to Louisville were poor to begin with, their situation did not improve. All these events promoted conflict and competition between city and county governments, an issue that continues at the present time (Savitch and Vogel, 1996).

Many in the city began to blame the county for the city's problems (Schulman, 1987). City leaders saw the county as draining its people and businesses away while at the same time using its central business district as a major employer and provider of governmental administrative services. In the 
1960 s and 1970s, the City of Louisville had some success in annexing adjoining parts of the county. However, most attempts at annexation were met with hostility and defeat. Finally in the early 1980s, city and county leaders decided that a merger between city and county government should be attempted. However, two referendums were narrowly defeated. For the city, the future did not look bright.

When "deindustrialization" hit the Louisville area, the results were very harsh (Norman and Hershberg, 1984). According to the Kentucky Department for Manpower Services, plant closings and permanent layoffs contributed to a loss of 35,000 jobs in the metro area from 1974 to 1983 (Norman and Hershberg, 1984). In 1974, the Louisville area had around 120,000 manufacturing jobs. By 1983, it was down to around 85,000, a level which has since fallen over the last 12 years. For every heavy manufacturing job lost, probably 2 to 4 other jobs were lost (Norman and Hershberg, 1984). This meant that the total number of jobs eliminated could have ranged from 105,000 to 175,000 throughout the metro area (which would include surrounding Kentucky counties and counties in southern Indiana).

Unemployment levels in the area were above those of the national average throughout most of the 1980s, a period that saw an outward migration of over 50,000 people from Jefferson County ( 1980 and 1990 Census of Population and County-City Data Book, 1983 and 1988 editions). Overall employment for Jefferson County reached a peak in 1979 (304,068 jobs). After 
taking a tumble, that employment peak was not surpassed until eight years later--in 1987 total employment reached 304,082 (County Business Patterns for Kentucky, 1970 to 1990 editions).

Some factory jobs such as those at the Brown and Williamson cigarette plant were moved out of town because of the city's bad labor climate even though the company's headquarters remained behind (Norman and Hershberg, 1984). Millions of dollars in local tax revenues were lost thereby straining the ability of the city to fund many services.

In summary, Louisville and Jefferson County suffered from several maladies. A fragmented government structure made economic development decisions cumbersome and difficult. The local area was divided along class, geographical, and racial lines. Because of a high reliance upon manufacturing employment, the Louisville economy was hit hard by recessions and plant relocations. Outward migration was becoming a problem. The challenge for local leaders was coming up with local economic development tools to fix the problem.

\section{Louisville's EZ: The Politics of EZ Development}

Events in Kentucky mirrored national economic trends. In 1979, John Y. Brown, Jr. was elected Kentucky's Governor on a platform of making the state more hospitable to business. Since his administration coincided with the trough of the recession, there was a feeling of urgency in the state capitol 
to do something about the state's suffering economy. Governor Brown appointed a task force to look into enterprise zone ideas. Other states had already started their own zones as an economic development tool for urban areas, although some of the targeted areas were not actually urban (Bartik, 1991). In 1982, the Kentucky General Assembly passed House Bill 505 (which later became KRS 154.45), a law allowing for the creation of enterprise zones in Louisville as well as other cities throughout the state. Zones were to be created geographically by using contiguous census tracts. Under the law, the average unemployment rate in a proposed zone had to be at least 1.5 times greater than the national average for an 18-month period. Also, seventy percent of the people in the zone were to have incomes below 80 percent of the city's median income, or the area must have lost 10 percent of its population between 1970 and 1980 (Stewart, 1983).

House Bill 505 allowed tax breaks for businesses in a zone that met specific criteria. To be certified as a "new to the zone" EZ business and in order to qualify for tax breaks, a new EZ firm had to draw at least 25\% of its work force from:

1) residents in the zone,

2) individuals unemployed for 90 days or more,

3) individuals receiving public assistance for 90 days or more, or

4) a combination of the above.

Firms already in the zone and conducting business in the EZ prior to its designation could be certified by making capital investments of at least $20 \%$ on net fixed assets (land, 
buildings, machinery, equipment or lease hold improvements), or by increasing its total number of employees by at least $20 \%$ with 25\% of those employees coming from the targeted workforce-people falling into one or all of the categories listed above. Firms already in the zone were to complete any "new activity" within 18 months after the date of filing an application for certification. The law also stated that subsidiaries or franchises of a new or existing business may be certified if their new site was within the zone and they maintained separate bookkeeping for business activity conducted within the zone.

In return, certified businesses were to be exempt from paying state taxes on profits from the sale of property in the zone, and exempted from all state taxes on interest payments on loans to qualified businesses in a zone, including mortgage loans. This latter provision was designed to encourage lending and capital formation. Also certified businesses would not have to pay motor-vehicle usage taxes, and they would not have to pay sales or use taxes on building materials if they remodeled. Sales and use taxes were also exempt on new and used equipment bought by businesses in a zone, and the businesses could carry forward a "net operating loss" against its current income for as long as the zone existed. In Louisville, many city fees and permits would be discounted while some local regulations were streamlined. Louisville's zone was scheduled to start in June 1983 and would terminate in July 2003 (House Bill 505 and Stewart, 1983). 
Mayor Harvey Sloane and the Louisville Board of Aldermen ultimately decided that the Ez would initially cover only 3.75 square miles west and south of Louisville's central business district. The EZ would consist of nine census tracts based on 1980 census tract boundaries and would comprise western Louisville's Station Park industrial complex, over 100 industrial employers, and 12,396 residents in about eight neighborhoods where about half of the available housing was public housing. The area was bounded by the Ohio River to the north and by portions of 15 th and 21 st streets as well as 18 th Street/Dixie Highway on the west. The southern boundary was composed of the Algonquin Parkway area (up to Shively), Colorado Avenue and over to a portion of $L$ \& $N$ railroad tracks leading down to Dakota Avenue in south central Louisville. Its eastern boundaries varied but included Crittenden Drive, Interstate 65, Fourth, Fifth and Sixth Streets and Roy Wilkins Boulevard (Figure 1, next page, shows approximately the geographic area initially included in the Louisville Ez using 1990 census tract boundaries). ${ }^{2}$ This area lost more than 18.8\% of its population between 1970 and 1980, and its unemployment rate between June 1981 and December 1982 was estimated at $24.5 \%$ (Stewart, 1983).

2 Between 1980 and 1990 census tract boundaries changed with some of the 1980 tracts being combined with others because many parts of Louisville and Jefferson County lost population between 1980 and 1990 . 


\section{Original Enterprise Zone (1983)}

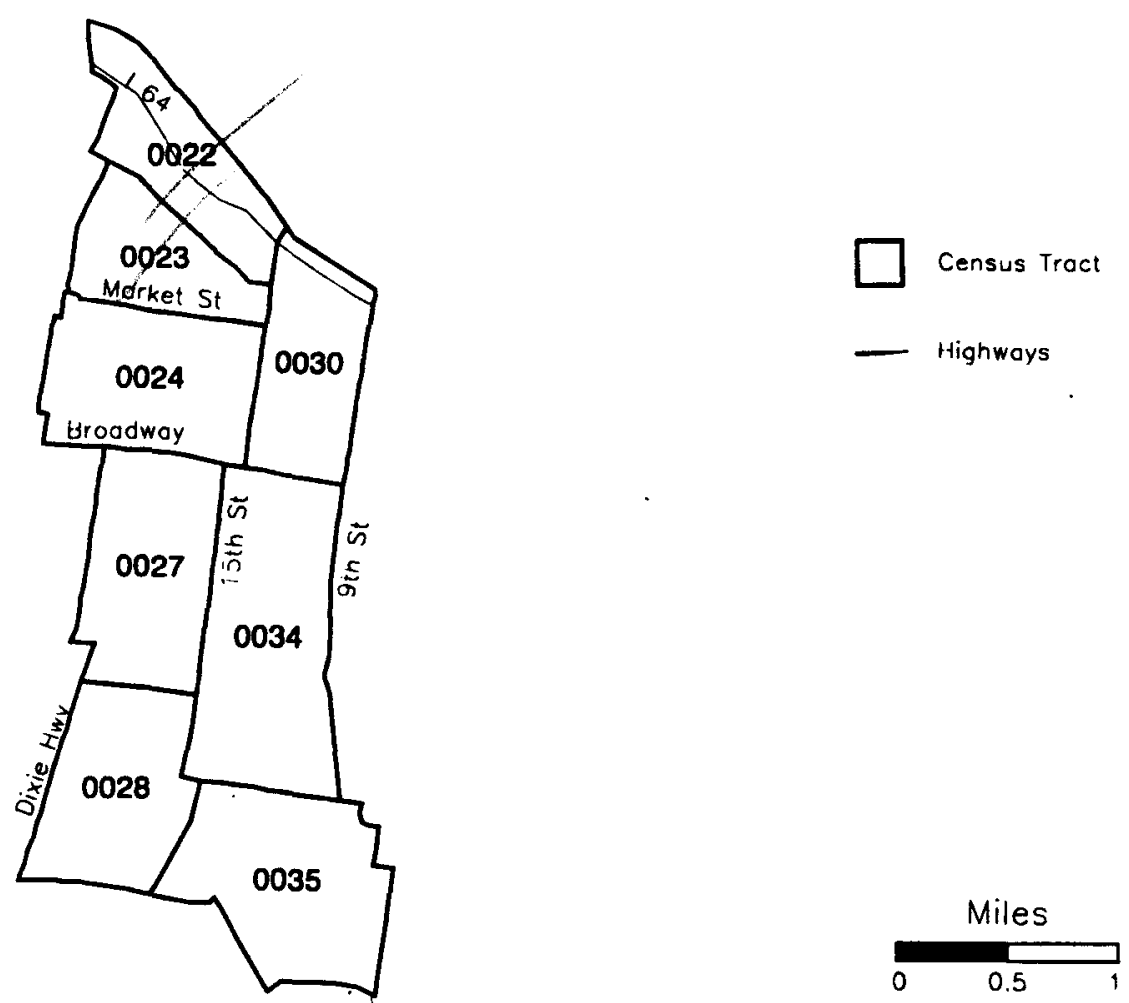

Figure 1

Source: Kentucky State Data Center 
According to Bendick and Rasmussen (1986), in an early appraisal of the original EZ, the Louisville EZ had spent or was committed to spending more than $\$ 57$ million in physical rehabilitation, land clearance and upgrading, and infrastructure development in the zone. The city was also to create a $\$ 30$ million investment pool of long-term financing in order to help businesses located within the zone (Bendick and Rasmussen, 1986, pp. 115-116).

Clearly, under the definitions of the law, and according to the original intentions of enterprise zone advocates, this part of the City of Louisville would seem to have been a good candidate for enterprise zone designation. It was clearly an economically disadvantaged area in need of help. But concentration on this area would only last until 1985. Ironically, the praise that Bendick and Rasmussen gave to Louisville's EZ was based on the compactness of its size and its focus on a blighted area (Bendick and Rasmussen, 1986). The initial focus, however, shifted radically as the geographic area encompassed by the zone changed twice over the next few years.

In February 1984, Louisville officials received permission from the Kentucky Enterprise Zone Authority to expand the zone (Davidson, 1992). The new EZ would take in the previous 9 census tracts but also add enough new tracts so that roughly 10 percent of the entire city's land would be in the new EZ (Shafer, 1984). The size of the EZ went from 3.75 square miles to 6.7 square miles as more of western Louisville 
and Standiford Field (now Louisville International Airport) were included. The only businesses that would absolutely not be allowed to obtain EZ certification would be junkyards, hazardous waste operations such as refineries, and adult-entertainment establishments. The Kentucky General Assembly approved the expansion, and preliminary plans for the new zone were released in October 1984. The full Ez expansion would be finalized in early 1985. Figure 2 on the next page shows a fairly accurate map of the expanded and modified EZ. ${ }^{3}$ After County Judge-Executive Mitch McConnel became a U. S. Senator in January 1985, Governor Martha Layne Collins appointed County Clerk Bremer Ehrler to take McConnel's place until the Fall 1985 election. Ehrler was expected to be a caretaker of the EZ until the next county-judge assumed office. He was not the caretaker everyone assumed, and apparently had an EZ agenda of his own.

To the dismay of city leadership and at the urging of state legislators whose districts did not participate in the initial Louisville EZ, Ehrler proposed creating a separate enterprise zone in southern and southwestern Jefferson county (Shafer, 1985). Along with several local banks, Ehrler also put together a $\$ 5.5$ million package to buy and develop land in eastern Jefferson County that would later

3 Figures 1 to 3 come very close to replicating EZ boundaries. There may be some error in these maps due to the fact that EZ boundaries were often drawn at a level below census tract boundaries, such as block groups and actual blocks. Because of the limitations of the mapping system utilized, 1990 census tract boundaries had to be used without further detail being possible. 


\section{Intermediate Enterprise Zone}
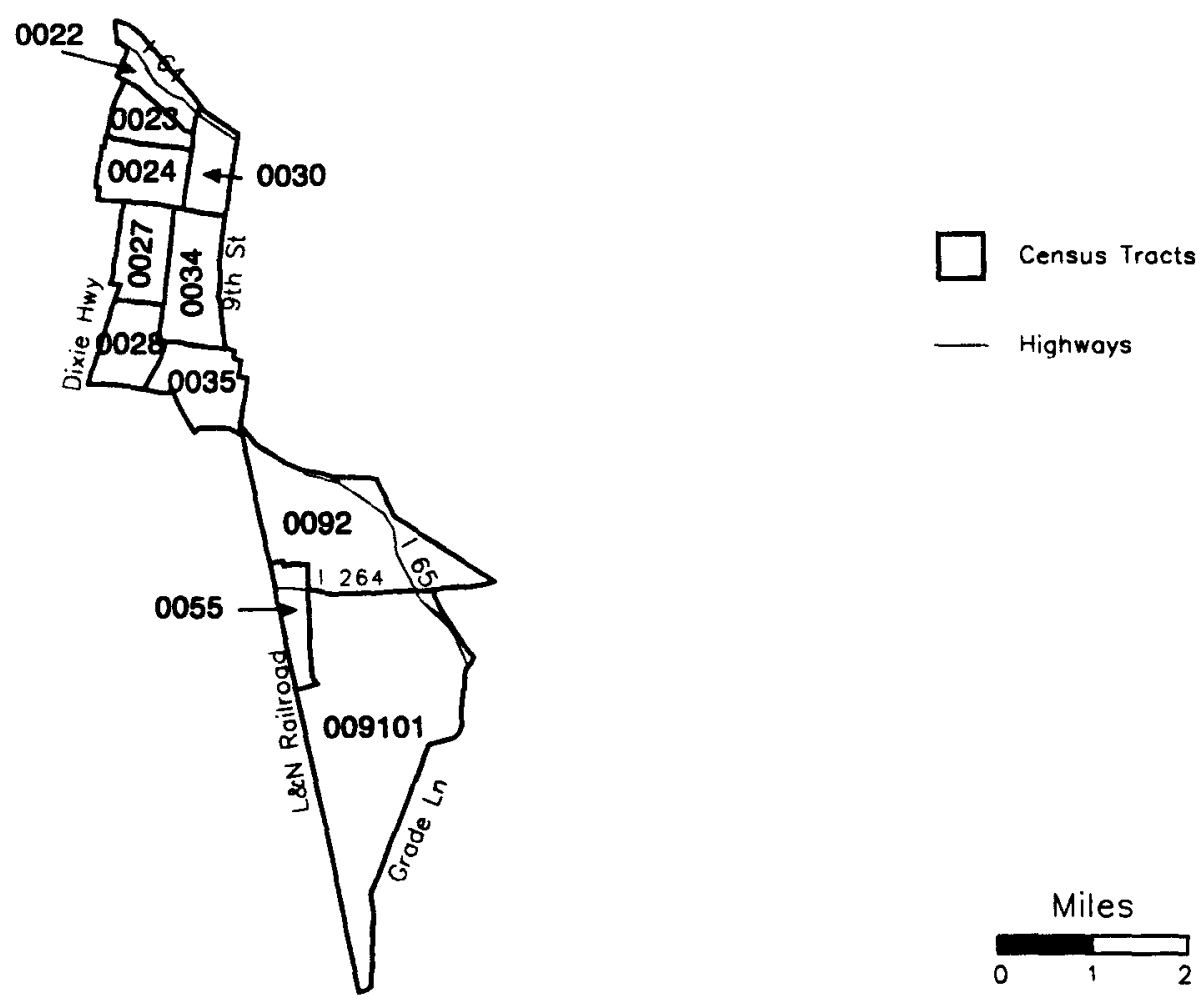

Miles

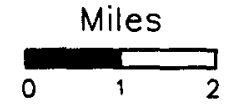

Figure 2

Source: Kentucky State Data Center 
become Anchorage Industrial Park (Shafer, 1985). Ehrler wanted enterprise zone designation for this area as well.

Both moves were considered a threat to the growth and survival of Louisville's EZ, and much political infighting occurred over attempts to create a county EZ. If Jefferson County created its own separate EZ, then having two EZs in the same county would violate state law. The City of Louisville would lose its EZ and Jefferson County would not be able to establish one on its own. ${ }^{4}$

Around the same time in 1985, the City of Shively, after suffering several years of fiscal hardship, tried to annex portions of adjacent unincorporated areas of southwestern Jefferson County. The annexation attempt failed, but Shively got both the city's and the county's attention. In an attempt to pacify Shively officials, a portion of the small suburban city would be allowed to join Louisville's EZ. Shively would be helped by both the city and the county so as to prevent any further annexation attempts (Shafer, 1985).

As an overall compromise, local officials decided to ask the 1986 General Assembly to expand Louisville's EZ into two of the three areas that Ehrler wanted to turn into a separate enterprise zone. A large share of southern and southwestern Jefferson County, including a portion of the City of Shively, would join Louisville's EZ (Shafer, 1986). These new areas

4 Recall that census tracts within an EZ must be contiguous and meet certain criteria to be economically distressed and blighted. The areas that Ehrler wanted to form into a county EZ would not be contiguous with city tracts nor would they be considered economically distressed or blighted (Shafer, 1985). 45 
would include an area south of Standiford Field stretching down to the Gene Snyder Freeway, bordered by Old Shepherdsville Road on the east and an area surrounding I-65 on the west. This area included Fern Valley Road and its chief resident the Louisville Ford Assembly Plant, one of the area's largest employers. Also, to be included were the Rubbertown industrial area in Lake Dreamland and the Riverport Industrial Park located in Pleasure Ridge Park. As a small token of appreciation to the city, some of the eastern side of Louisville's downtown as well as the Phoenix Hill and Butchertown neighborhoods were included in the EZ (see Figure 3, next page, and Figure 4, following page, which shows the full-size Ez's relative size to the rest of the county). Some local political figures argued that Ehrler and Shively officials blackmailed the city into giving them what they wanted in the first place--another tool for economic development. While this interpretation may be incorrect, it is only rational that Shively and county officials would want to promote the interests of their constituents by helping their jurisdictions to create a business friendly environment.

Nevertheless, the city would get something substantial in return. In 1986, Mayor Jerry Abrahamson and the new County-Judge Executive, former Mayor Harvey Sloane, agreed to a City-County Compact that included revenue sharing between the city and the county as well as greater cooperation in running local government services and promoting local 


\section{Current Enterprise Zone (1986)}
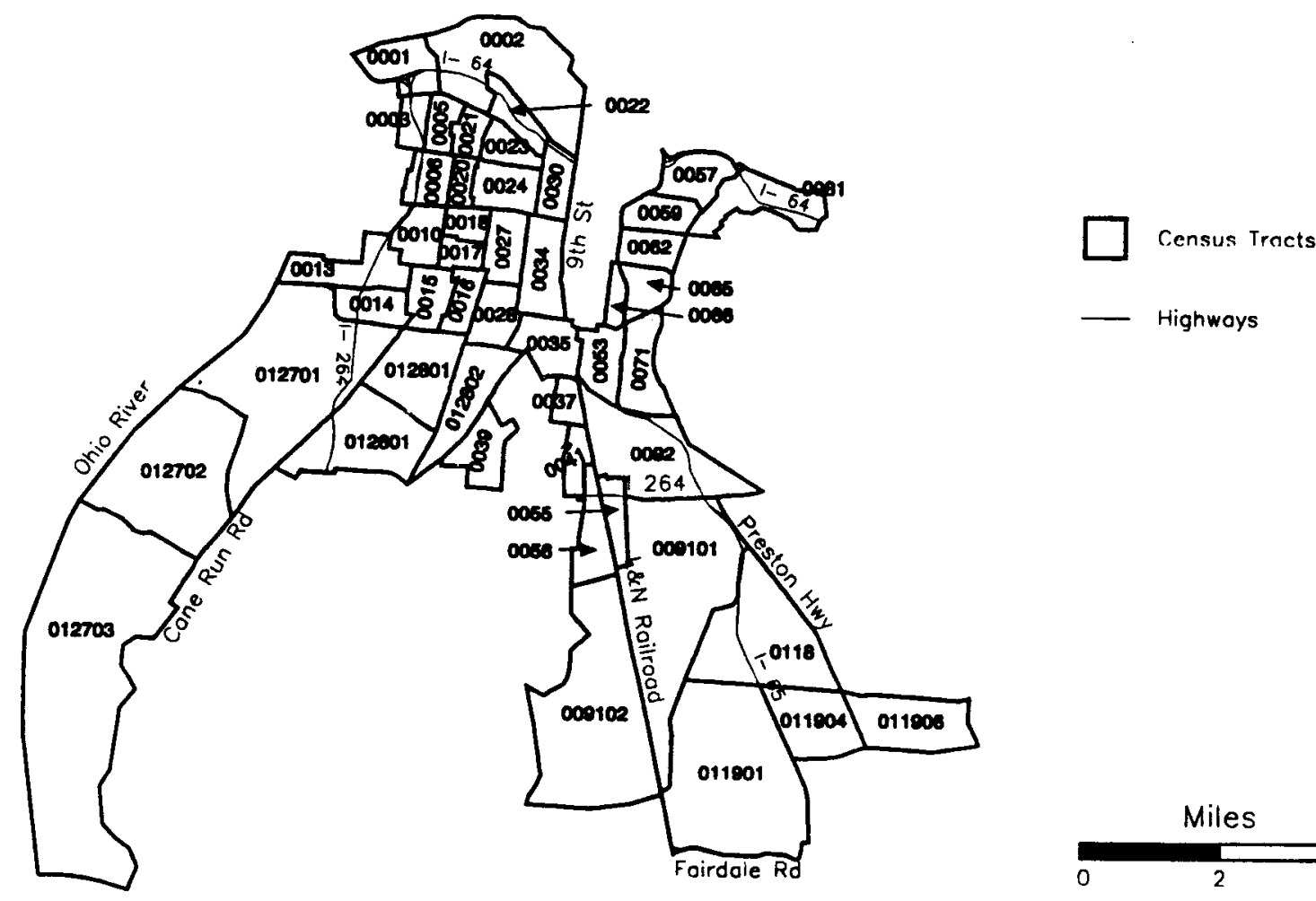

Miles

Figure 3

Source: Kentucky State Data Center 


\section{The Louisville/Jefferson County}

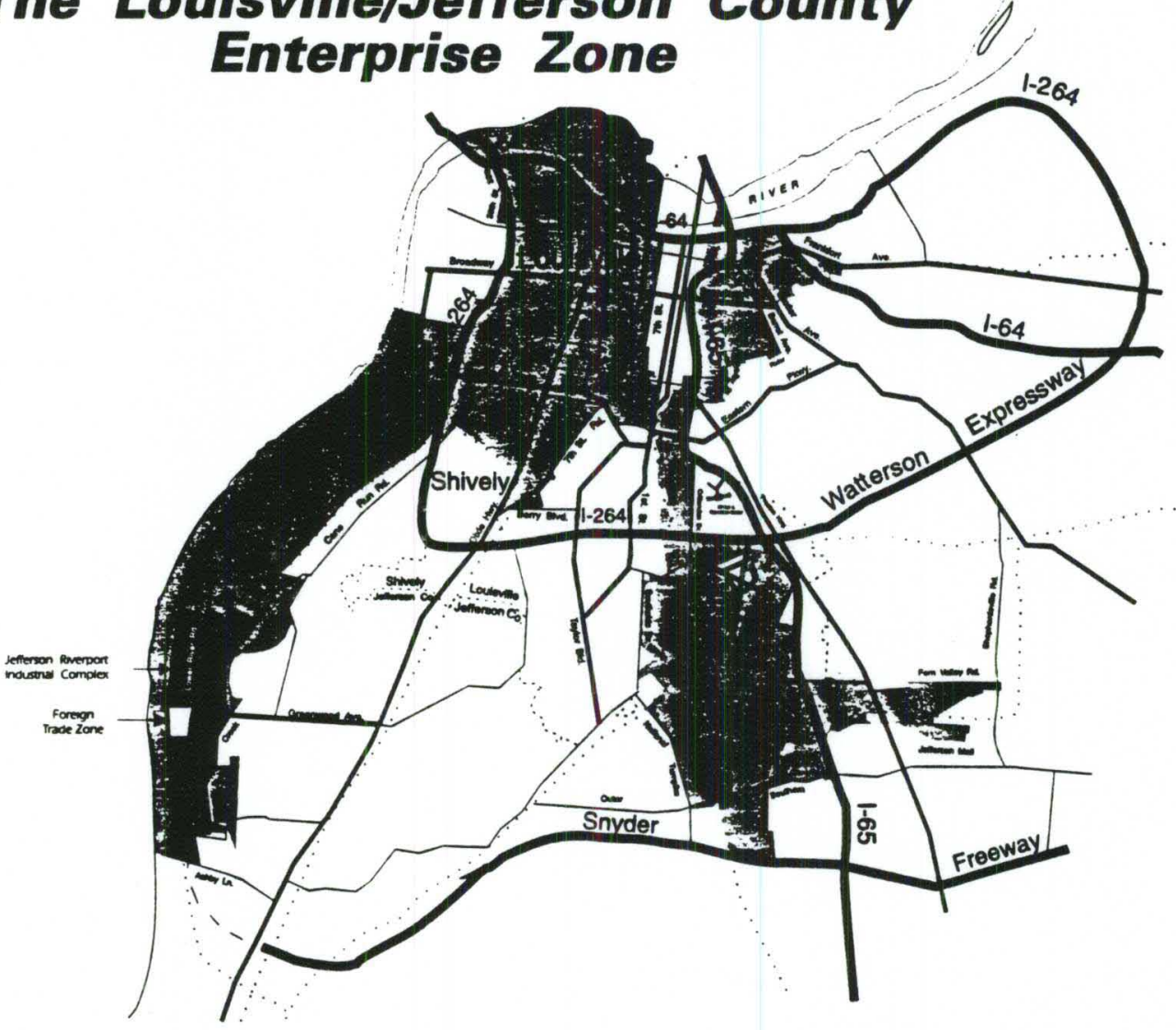

Figure $\quad 4$

Source: Office for Economic Development (OFD) 
economic development. In return for sharing in its rapidly growing occupational tax revenues, the county would now be able to participate in the Louisville EZ. The Compact, along with the EZ expansion, were approved by the 1986 General Assembly with both scheduled to go into effect July, 1986 (Shafer, 1986).

If compromises and new government relationships were necessary to start bringing together a divided community, then the expansion of the Louisville EZ could be justified upon social and political grounds. The city was no longer as desperate as it once was for revenues. Even though $33 \%$ of occupational tax revenues come from city residents, the city was now going to receive $55 \%$ of these revenues. In return, the county would get something to help it with economic development. However, in the process of expanding the zone, local leaders abandoned general EZ theory and principles:

\section{keeping the zone focused on economically distressed and}

physically blighted areas. The new zone was so large, according to critics of the compromise, that the chronically depressed areas that the enterprise zone was supposed to help would probably get lost in the overall growth of the county's economy.

The new EZ would consist of 45.7 square miles and over 60 census tracts mostly sprawling over portions of western, southwestern and southern Jefferson County. Many of the new areas were not economically disadvantaged as defined in House Bill 505. However, if one took all the new census tracts 
added to the zone and lumped them together with all of the old census tracts, then the average of all the census tracts met the standards put forth in House Bill 505 (Davidson, 1992).

In order to observe the law's mandate that all the census tracts had to be contiguous and adjoining, the University of Louisville's main campus was included in the zone, even though it is a non-profit institution and has no permanent year-round residents consistent with the enabling legislation (Davidson, 1992). U of I had to serve as a connection between the eastern and western sides of the $\mathrm{EZ}$.

Just as with the University, Louisville's airport could not legitimately be considered an economically distressed area. Yet because the airport was at one time surrounded by low income neighborhoods, United Parcel Service and other firms doing business near or at the airport, were able to obtain enterprise zone certification (Davidson, 1992). Most importantly, in the rush to provide an economic development program for Louisville and Jefferson County, no real monitoring and evaluation system was set up for Louisville's EZ program. There was no real tracking of the program's costs and benefits. By 1990, the failure to evaluate the Ez program had become a serious political issue in the local press.

\section{The zone Comes under Scrutiny}

In 1990, the Louisville and Jefferson County office for Economic Development (OED) distributed a press release titled 
"The Louisville Enterprise Zone: Louisville's \$1 Billion Success Story." The report touted the accomplishments of Louisville's Ez by stating that "over 9,000 jobs have been created and over 24,000 jobs have been retained" and that Louisville's EZ "became the first Enterprise Zone in the country to reach the $\$ 1$ billion capital investment mark." (Office for Economic Development, 1990, p.1). Despite these impressive numbers, the report did not disclose how they were calculated or arrived at.

On December 1, 1991, the EZ received a scathing review in an article published in Louisville's Courier-Journal (Heath, 1991). Reporter David Heath uncovered abuses in the use of the EZ's motor vehicle usage tax exemption. Some business owners were purchasing luxury cars and registering the cars under the business's name, but using the vehicles for purely personal reasons, thereby escaping any personal property tax liability for the automobiles. Heath's investigation concluded that many of $O E D^{\prime} s$ numbers on jobs created and retained as well as dollar figures for investment in the EZ were greatly inflated. OED never subtracted from their totals firms that went out of business or relocated outside of the zone.

Heath's investigative reporting, also came up with other disturbing revelations. OED record keeping never disclosed whether some jobs would have been created regardless of the presence of the EZ. Some firms locating in the EZ after its creation in 1983 were not even aware of $\mathrm{EZ}$ incentives until 
after being in the zone for a period of time. Also, there was no monitoring of how many disadvantaged workers were actually being hired. One of the goals of the EZ was to help these workers gain employment, but OED could not verify the total number of disadvantaged workers hired. The state's Department for Employment Services did not then, and does not now, check or verify Ez company records.

Finally, in a survey of $O E D^{\prime} s$ listings of the top ten companies that had created the most jobs and investment, Heath found that OED records were greatly in error. Of the top ten companies credited with creating jobs, Heath found that OED overreported the actual number of jobs created by 2,210 . Of the top ten companies credited with creating capital investment, he found that OED overreported by $\$ 132.7$ million. Heath simply called and spoke to company officials in order to find the actual numbers. One of Heath's most interesting conversations was with Humana, Inc. officials. OED credited Humana with creating 1,100 jobs at a new office location on 101 East Main street. When asked if that number was accurate, Humana stated that only around 100 new jobs had been created due to the new downtown offices. The other 1000 new jobs were actually existing employees who were brought in from other offices throughout Jefferson County. Additionally, when asked if the company would have undertaken the renovation of the building necessary to create the new office building regardless of $\mathrm{EZ}$ tax incentives, a company spokesman said "yes." Even though the renovations would have been made 
in any event, over $\$ 600,000$ in sales taxes were lost to the state treasury.

Around the same time, hearings were being conducted in Frankfort on the efficacy of enterprise zone programs throughout the state (Legislative Research Commission (LRC) Memorandum No. 460, 1991). In 1990, the Kentucky General Assembly's Cities Committee created the Subcommittee on Enterprise Zones because of press reports throughout the state that chronicled abuses of EZ incentives. According to the Subcommittee's report, after eight meetings over two years, the Subcommittee "was unable to determine how effective the enterprise zone program has been in creating new economic activity, or how the program's tax exemptions have affected state revenues. The statutes that govern enterprise zones (KRS 154.650 to 154.705 ) have had little review or amendment since they were enacted" (LRC Memorandum No. 460, p. 2).

Because of these findings, the 1992 General Assembly mandated stricter monitoring and reporting on enterprise zone activities throughout the state beginning the in 1992-1993 Fiscal Year. The State Enterprise Zone Authority (part of the Cabinet for Economic Development) was required to submit annual reports on the number of new jobs and investment created within each zone. The Kentucky Revenue Cabinet was also to begin submitting annual reports on the fiscal impacts of enterprise zone tax breaks and incentives.

There were also changes made in EZ incentives. The exemption of usage taxes on automobiles was limited to just 
the first $\$ 20,000$ of value whereas the usage tax exemption for trucks was allowed to stay at $100 \%$ of value. Exemptions for net operating losses were eliminated as well as exemptions on income earned from loans to certified EZ companies. The loss of these incentives were substituted with one that put more emphasis on hiring employees from a targeted workforce--those receiving public assistance for at least 90 days before being hired by a certified company. For each worker hired from this group, Ez companies could claim a tax credit of $10 \%$ of such a worker's annual wages, up to a maximum of $\$ 1500$ per worker. Any unused tax credits could be carried forward for up to five years.

Additionally in 1992, Kentucky's Enterprise Zone program got an unpleasant surprise from the state's Attorney General Office. Assistant Attorney General Ross T. Carter issued an opinion that said Kentucky's zones were chosen arbitrarily in violation of the Kentucky Constitution's ban against special legislation favoring certain jurisdictions over others (Heath, 1992). The opinion further claimed that the EZ law was

special legislation because the zones were not necessarily in the most depressed areas of the state, but simply areas which have applied for special tax benefits; the benefits are given on a "first-come, first-served" basis which arbitrarily denies some needy areas tax relief; and even if a zone becomes a thriving area, businesses in a zone will continues to receive tax breaks for 20 years. Attorney General opinions do not carry the force of law and thus far no one has challenged the 
constitutionality of Kentucky's EZ program. In the meantime, state legislators began to work on refining EZ legislation so that its constitutionality would be difficult to challenge (Heath, 1992). Some legal scholars, however, were increasingly alarmed at how state and local economic development policies were being used by local governments to justify a public purpose (Rubin, 1993 and 1994). In the past, state and local government intervention into the private sector had to be justified by a public purpose--either markets did not provide certain goods (such as roads, bridges, etc.) or markets had to be regulated (health and safety standards, etc.). During the 1980s, state and local tax breaks to businesses were seen as necessary in order to promote economic development since the federal government had decided to play a smaller roll in community development. Many tax incentives and subsidies given to private enterprises were justified legally under the public purpose doctrine. In other words, in many jurisdictions local economic development had attained the same status as providing police and fire protection. In Rubin's (1993 and 1994) opinion, this was not an appropriate use of the public purpose doctrine. Private businesses, it is felt, should not be subsidized or favored in any way through the spending or sacrificing of public tax revenues, such as was done when a new General Motors plant was built in Poletown within the Detroit metropolitan area (Wylie, 1989). 


\section{Summary}

Consistent with the literature reviewed in Chapter 2 and the issues raised in it, the Louisville Ez experience is very similar to others in that the EZ was not carefully planned, implemented or monitored either for job creation and retention, as well as for capital formation and business creation. In reality, political compromises and considerations seemed to drive the evolution of the EZ. The original goals of economic development and community revitalization for a depressed urban area suddenly became just one part of a program that tried to achieve many different goals and objectives. During the entire history of the Louisville EZ, there has never been a comprehensive evaluation of the program's effectiveness in terms of costs and benefits. Nor has any one really tried to establish the number of jobs that would have been created had the $\mathrm{EZ}$ not been in existence. Despite this, the State Enterprise Zone Authority announced on August 13, 1996 that it was considering another expansion of Louisville's EZ from 45.7 to 63 square miles. The main reason given for expanding the zone was that the new area to be included now met the definition of a distressed area (Shafer, 1996) .

All of this is not surprising. According to Rubin and Wilder (1996):

One weakness in the base of knowledge about state enterprise zones is the lack of attention to the planning process as an element in program implementation. The failure to include planning 
process requirements in state legislation that authorizes enterprise zones may critically influence program outcomes; yet this issue is generally not addressed in major studies of the effects of enterprise zones. The omission of planning elements from state enabling legislation for enterprise zones and from subsequent program evaluations should be of special interest to planners (p. 474).

According to the authors, Louisville's EZ would be no different from other EZs in that a plan to implement the goals and objectives of KRS 154 was never created. Without a strategic plan for $\mathrm{EZ}$ implementation, it is not surprising then that the program changed its focus over time. Absent a plan for implementation, it is also not surprising that there never was any real monitoring of program outcomes (Rossi and Freeman, Chapter 4, 1985).

Rubin and Wilder (1996) also note that EZs were created during a time when strategic planning had not yet caught on in the public sector at the state and local level (p. 485). Also given the severity of the recession of the early 1980 s as well as the federal government's withdrawal from state and local matters during the 1980s, it is conceivable that many Ezs were created in a rush to do something, or anything, to address local economic and fiscal problems. That is, EZs could have been created in a vacuum that did not allow for strategic planning or implementation.

In the next chapter, a detailed plan for evaluating the accomplishments of the Louisville zone will be presented. The evaluation plan will utilize cost benefit and shift-share analysis. A quasi-experimental and time-series design will 
allow estimation of whether or not the various incentives produced the results intended by the enabling legislation. 


\section{Methodologies for Evaluation}

\section{Introduction}

Similar to prior studies, the research design used to evaluate the Louisville EZ case uses a multi-method approach. Consistent with Rossi and Freeman (1985, 3rd edition) and Haveman and Margolis $\left(1983,3^{\text {rd }}\right.$ edition), this dissertation follows the basic principles of program evaluation and policy analysis. The main issue here is whether the EZ accomplished any of its goals and objectives and how well it accomplished them. The basis for generating the hypotheses to be tested will come from the goals that were to be achieved by the EZ as articulated in KRS 154.45 .

KRS 154.45 begins as follows:

154.45.001. Purpose of Enterprise Zone Program.The General Assembly hereby finds and declares that the purpose of the Enterprise Zone Program is to revitalize economically depressed areas of the state. It is the intent of the General Assembly to achieve this purpose by adhering to the following goals:

(1) Improve the quality of life of individuals that reside within an enterprise zone by providing employment opportunities, job training, and neighborhood improvement programs;

(2) Encourage economic activity by assisting and maintaining existing business within an enterprise zone;

(3) Encourage economic activity by stimulating the influx of new business within an enterprise zone; and 
(4) Eliminate blighted and deteriorated areas within an enterprise zone that feature chronic abandonment or demolition of residential or commercial structures or property. (p. 412 of Kentucky Revised Statues, emphasis added).

The rest of the legislation includes definitions of what constitutes an EZ, what is a "targeted workforce," etc. (refer back to chapter 3, pages 37-38 and see Appendix). The enabling legislation also specifies what application processes must be undertaken for a locality to become an $\mathrm{EZ}$, as well as identifies the types of incentives that can be offered to firms (see chapter 3, pages 37-39 and Appendix). KRS 154.45 also defines what type of area is eligible for EZ designation:

"(1) Any area of a local government may be designated an enterprise zone that:

a) Has a continuous boundary, and

b) Is an area of pervasive poverty, unemployment, and economic distress.

(2) An area meets the requirements of subsection (1) (b) of this section if:

a) The average rate of unemployment in the area for the most recent eighteen (18) month period for which data is available was at least one and one-half (1.5) times the average national rate of unemployment for that eighteen (18) month period; and

b) At least seventy percent $(708)$ of the residents living in the area have incomes below eighty percent $(80 \%)$ of the median income of the residents of the local government requesting designation of an enterprise zone; or

c) The population of all census tracts in the area decreased by ten percent $(10 \%)$ or more between 1970 and 1980 and the local government requesting designation establishes in writing, to the satisfaction of the authority, that either:

1. Chronic abandonment or demolition of commercial or residential structures exist in the area, or

2. Substantial tax arrearages of commercial or residential structures exist in the area." (p. 416 of Kentucky Revised Statutes, emphasis added). 
Additionally, the legislation created the Enterprise Zone Authority of Kentucky, which was to oversee the administration, implementation and evaluation of Kentucky's enterprise zones. However, the Authority was never given any funding to do an adequate job of overseeing Kentucky's EZs (interview with Sarah Bell, 1996). The Kentucky Revenue Cabinet is also mentioned in KRS 154.45 as being responsible for collecting data on Kentucky's EZs. However, the Revenue Cabinet claimed that it was never given the money to adequately collect data (LRC Memorandum No. 460, 1991). Therefore, there was no real monitoring of the Louisville EZ's performance until amendments were added to KRS 154.45 in 1992, and additional funding was given to various state agencies (interview with Sarah Bell, Deputy Secretary of Kentucky Cabinet for Economic Development, 1996).

In order to evaluate the impact of the Louisville and Jefferson County EZ program, program outcomes and impacts will be assessed by answering the following questions. The questions are posed as general research hypotheses, and were derived from the goals and objectives identified in KRS 154.45. This method of deriving research hypotheses and questions directly from the enabling legislation is consistent with the fundamentals of policy evaluation and impact analysis (Rossi and Freeman, 1985; and Haveman and Margolis, 1983).

1). Did the EZ increase employment at a greater level than what would have been the case had no incentives or regulatory relief been offered to businesses? 
2). Did the EZ stop or slow outward population migration from the zone area?

3). Did the EZ increase employment among disadvantaged and long-term unemployed workers who lived in the EZ area?

4). Did the costs of the EZ program outweigh its benefits? If so, could money used for the $\mathrm{EZ}$ have been used more effectively in other economic development programs?

5). Was the wealth and income of residents within the EZ increased over the years?

6). Did the EZ increase employment and attract capital at a rate greater than those portions of Jefferson County or Jefferson County as a whole that were not in the Ez?

7). Were the goals and objectives of the state legislation which allowed the creation of the EZ accomplished? If they were not accomplished, then why not?

The language appearing in bold print stresses the relationship among the research hypotheses and to the goals and objectives identified in the enabling legislation (KRS $154.45)$.

\section{Methods to be Used}

Several methods will be used to assess the effectiveness of the EZ. The primary research design used is a quasiexperiment as discussed by Cook and Campbell in Quasi-Experimentation (1979). Quasi-experimentation will play a key role in this study because it is essential to compare 
and contrast similar areas within Jefferson County. Areas that received the economic development stimulus of $\mathrm{EZ}$ incentives will be compared to counterpart areas in Jefferson County that did not receive the advantages of $\mathrm{EZ}$ incentives. These counterpart or comparison or control areas were chosen because of their similarity either to the entire EZ or its sub-areas. If the economic incentives accomplished their mission, then one would expect to see changes occurring within the EZ or its component areas that were not occurring in the control areas over a given time period.

For example, if $\mathrm{EZ}$ incentives were successful, then one would expect that unemployment and blight would decrease in the EZ at rates higher than comparable areas not eligible for incentives. Also according to the logic of the legislation, one should see substantial job and business growth as well as new construction in the EZ over time, but not in the control or comparison communities. Such incentives would be expected to reverse the decline previously experienced in an EZ designated area. Perhaps the EZ area could even be expected to overtake those portions of the county not included in the EZ as far as growth rates of job and business creation as well as growth rates of residential and commercial investment. Finally, one would expect to see a stop to the outward migration from an EZ designated area over time.

On the other hand, if incentives did not work, one would expect to see continued economic decline and outward migration from EZ neighborhoods at a rate greater than or equal to that 
experienced by control or comparison areas. Similarly, one would expect to see job and business growth within the Ez to continue to at least remain flat if not continue to decline when compared to other areas of the county which did not receive $\mathrm{EZ}$ incentives.

In order to implement the quasi-experiment, it is necessary to have a pre-test and a series of post-tests, and control communities that are identical in all respects save for the presence of the EZ incentives. In this study, numerous outcome measures spanning the years 1980 to 1996 will be used to evaluate the Ez program. The next few pages give an outline of the outcome measures, data sources and analytical methods to be used in the EZ program evaluation.

\section{Job Creation Analysis}

As mentioned earlier, a shift-share analysis of job creation within the EZ was conducted. Job growth in the EZ was analyzed by controlling for national economic and specific industrial shifts that would influence changes in sectoral employment within the $\mathrm{EZ}$. An important consideration in this analysis was to try to estimate the job growth that would have occurred. in the EZ over the last 13 years regardless of local incentives, but instead due to national and specific industry trends that were occurring throughout the area.

Sectoral job growth in the EZ was compared to job growth in Jefferson County over two equivalent time periods--1980 through 1990 and 1981 through 1994. The approach taken was 
similar to that used in Rubin and Wilder (1989) and Dowall (1996). Also, the rate of growth for the two control areas to be analyzed (the Newburg Area as well as the Bluegrass Industrial Park-Jeffersontown Area) was compared to the job growth of Jefferson County over the same two time periods. Job creation was analyzed by comparing job creation within the Ez to the number of jobs created throughout the county and control group communities over the periods of 1980 to 1990 and 1981 to 1994. Job creation was measured by examining Louisville and Jefferson County office for Economic Development (OED) records, surveys done by the Urban Studies Institute (USI), County Business Patterns data at the zip code level from 1981 to 1994, and from the manipulation of census tract data from the 1980 and 1990 Censuses of Housing and Population by University of Louisville researchers (Coomes and Price, 1994). The last two data sources were used in a shiftshare analysis of EZ job creation following Dowall (1996), and are considered to be the most accurate sources available for estimating net changes in job numbers and industrial composition over a given period of time.

\section{Neighborhood revitalization}

Demographic, employment and occupational changes in the EZ were analyzed and compared to changes in the rest of Jefferson County by looking at data from the 1980 and 1990 Bureau of the Censuses Housing and Population Survey. Data at the tract level were aggregated for the EZ and were compared 
to data at the tract level aggregated for two control group communities within Jefferson County, the rest of Jefferson County outside of the EZ, and Jefferson County as a whole. The purpose of such a comparison was to see if $\mathrm{EZ}$ incentives and the geographic enlargement of the EZ had any effect on the neighborhoods and residents of the EZ during the first 7 years of the program. Changes in demographic patterns in the area of Jefferson County outside of the EZ served as a non-equivalent control communities to see if EZ program interventions had any impact on slowing the decline of neighborhoods within the EZ. The 1980 and 1990 dates served as the pre-test and post-test dates, and were used for timeseries estimates of possible changes.

The two most important control group areas within Jefferson County that were used was the Newburg Area in southeastern Jefferson County and the Jeffersontown-Bluegrass Industrial Park Area in eastern Jefferson County. The Newburg Area was selected because its socioeconomic conditions closely parallel those of EZ neighborhoods, yet this area received none of the same incentives that the $\mathrm{EZ}$ received in order to help the area develop economically. The JeffersontownBluegrass Industrial Park area was selected because it too received none of the incentives that the EZ received and because it was felt that the development and expansion of Louisville's airport within the EZ was similar to creating an industrial park within the EZ. The Jeffersontown-Bluegrass Industrial Park area grew from a mostly rural, underdeveloped 
portion of Jefferson County to an affluent and job-generating edge-city within the county.

Neighborhood revitalization can be best examined by looking at the results of 1980 and 1990 Census data (1980 and 1990 Censuses of Housing and Population). By aggregating data from tracts within the EZ, changes in the data from 1980 and 1990 were compared to demographic and socioeconomic changes that occurred in the control group communities, the rest of Jefferson County as well as Jefferson County in general. This comparison served as a pre- and post-test evaluation with the aggregation of data at the census tract level for the EZ compared to aggregate data at the census tract level for the control communities, the rest of Jefferson County and then compared to Jefferson County as a whole.

\section{Usefulness of EZ incentives to Firms within EZ}

A critical component of many program evaluations is to ask program participants if the interventions used in the program actually made a difference in participants' behavior or decisions. In order to ascertain program usefulness, a survey was administered to 851 firms located within the EZ in July and August of 1996. Among the items included in the survey were questions that asked respondents if they had used any EZ incentives, and if so, to what degree did the incentives make a difference in making hiring and capital investment decisions. The results of the survey conducted by USI during 1996 will indicate how EZ firms evaluated tax 
incentives and their importance. The survey data are used extensively in the cost-benefit analysis of $\mathrm{EZ}$ incentives.

\section{Changes in Residential Property Values}

One way to measure any increase in community well-being within the $\mathrm{EZ}$ is to measure any increases, in the value of residential property. If property values within the Ez did not appreciate at the same rate as property outside of the EZ, or worse, if property values declined, then this would be taken as a sign that the EZ incentives did not help with neighborhood revitalization or development. Changes in residential wealth within the EZ were compared to the control communities, the area of Jefferson County outside of the EZ, and Jefferson County in general. The sources of data utilized for this comparison were the Jefferson County Property Valuation Administrator's (PVA) Office and the 1980 and 1990 Censuses of Housing and Population.

As a way to gauge whether there has been an increase in the wealth of residents in the $\mathrm{EZ}$, records from the Property Valuation Administrator's office were examined to see if property values within the EZ significantly increased when compared to the two control areas, and to all of Jefferson County over the same time period. If there is shown to be no significant difference, then the argument that EZ status helped EZ neighborhoods will be weakened.

Another way to test for possible increases in community wealth or community revitalization within the $\mathrm{EZ}$ is to look at 
the rates of residential and non-residential construction and home mortgage lending within the EZ compared to the control areas and to Jefferson County. Data from the St. Louis Federal Reserve's report for the Home Mortgage Disclosure Act (HMDA data) were used to see if the rate of home lending in the EZ area differed substantially from the control communities and the county. ${ }^{5}$ Again, any significant differences in home lending or new construction undertaken within the Ez compared to other areas over the same time period was used as a possible measure of EZ program success or failure in revitalizing EZ neighborhoods. This is important to assess because one of the primary purposes of the original EZ legislation was to help impoverished, blighted urban areas.

\section{Residential Investment within the $\mathbf{E Z}$}

This part of the EZ evaluation attempted to determine whether EZ incentives played any role (whether directly or indirectly) in creating any new residential construction and development within the EZ when compared to the control communities, the rest of Jefferson County outside of the EZ, and Jefferson County in general. If the EZ incentives had any role in community revitalization, one would expect that mortgage lending activity would have shown an increase greater than that of the control areas, the rest of Jefferson County and Jefferson County in general during the time periods considered.

5 The HMDA data bank will be explained in greater detail in 
The HMDA data bank should show if there was a significant difference between the EZ and the other communities when it comes to home mortgage lending from 1981 to 1994. Increases or decreases in home mortgage lending would also be an indirect indication of construction and reinvestment activity as well.

\section{Ez Costs and Benefits: Job Creation and Capital Investment and Creating Jobs for Disadvantaged Workers}

Finally, and perhaps most importantly, the costs and the benefits of the EZ program were estimated and calculated. Tax losses over the last 13 years due to $\mathrm{EZ}$ incentives were estimated and weighed against all possible EZ benefits derived (tax withholdings from workers employed due to EZ incentives; investment undertaken as a result of $\mathrm{EZ}$ incentives, etc.). The cost-effectiveness analysis of the EZ program is a critical component of the dissertation, for even if the EZ program did cause an increase in investment and job creation beyond what would have been the case in the absence of EZ incentives, and if program costs outweigh program benefits, then one must question the financial success of the program and whether tax dollars could have been put to better use in an alternative economic development initiative.

Obviously, program efficacy has to be gauged according to how cost-effective the program is. If program costs and costs per job created outweigh program benefits and benefits per job created, then the efficacy of the program must be 
doubted.

Using records from OED, the Kentucky Revenue Cabinet (KRC), the Kentucky Legislative Research Commission (LRC), and the USI survey, estimates of EZ costs and benefits from 1983 to 1996 were calculated to see if program costs were offset or outweighed by program benefits. The costs per job created were weighed against the estimated payroll tax revenues generated per job. In doing these calculations, it was important to control for jobs that would have been created regardless of $\mathrm{EZ}$ incentives. The shift-share analysis and survey results mentioned earlier was used to control for this possibility.

The benefits of more capital investment within the EZ were not easily quantified. Often new plant and equipment can lead to the creation of more jobs, or new plant and equipment can lead to labor-saving techniques that can actually eliminate existing jobs. Only a cost per dollar of investment figure can be arrived at using the data available. If we assume that all new investment is beneficial (i.e., it generates jobs), then a low cost per dollar of capital investment could be taken as a sign of $\mathrm{EZ}$ incentives accomplishing their goals. This cost per dollar of investment, however, must be tempered by what businesses would have done had EZ incentives not been in place. To make adjustments for that, one must look at survey results. Also, rates of capital investment in the $\mathrm{EZ}$ were compared to the control communities and to Jefferson County. The benefits of 
attracting more capital cannot be estimated as easily as that for labor. With labor, one can estimate a certain amount of payroll tax revenue that the state will receive. With capital investment, one can only assume that firms undertake investment because of either increased profitability or the possibility of increased profitability due to future expectations.

\section{Other Methods and/or Sources of Data and/or Information}

It should be pointed out that many sources of information interspersed within the methods to be used for program evaluation came from interviews with various government officials, a newspaper reporter, and corporate public relations directors. These interviews will be cited throughout the dissertation. Records, annual reports and press releases from the Louisville and Jefferson County office for Economic Development (OED) were used as a source of data and information. Finally, information and data from news articles in Louisville's The Courier-Journal were used extensively.

\section{Summary}

The following chapters will evaluate the efficacy of the Louisville-Jefferson County Ez by using the methods and data sources discussed above. The next chapter examines how well the EZ program promoted neighborhood revitalization. 
Following that, the next two chapters will assess, through the shift-share method, how well the Ez did in creating jobs. Following the shift-share analysis, the costs and benefits of the EZ program are analyzed.

Finally, in the cost-benefit analysis chapter, data from the Kentucky Revenue Cabinet will be used to determine how many people previously on "public assistance" found jobs due to the EZ program, and how much were the costs per job. A key question here is not so much one of method but whether this component of the program was ever an important one. Preliminary results seem to indicate that this incentive was the least used among the others. 


\section{CHAPTER $V$}

\section{Louisville EZ Performance Evaluation: Neighborhood Revitalization}

\section{Overview}

KRS 154.45 declared the purpose of EZs was to "revitalize economically depressed areas of the state" (p. 412). To accomplish this, the law set forth the goal of improving "the quality of life of individuals that reside within an enterprise zone by providing employment opportunities, job training, and neighborhood improvement programs" and by eliminating "blighted and deteriorated areas within an enterprise zone that feature chronic abandonment or demolition of residential or commercial structures or property" (p. 412, emphasis added).

As the literature review in a previous chapter noted, and as the above quote indicates, neighborhood revitalization has been a central and important goal of almost all EZ programs. This chapter of the study looks at how well the Louisville EZ accomplished neighborhood revitalization and improvement by looking at Census Bureau data, residential investment data and changes in property values within the $\mathrm{EZ}$ compared to another part of Jefferson County, Jefferson County outside of the EZ, and Jefferson County as a whole. 


\section{Evaluating Neighborhood Revitalization using Census Data}

Neighborhood revitalization and quality of life are terms that can be interpreted broadly. Using data from the 1980 and 1990 Censuses of Housing and Population, Tables 5-1 through 5-6 show how the original EZ (3.75 square miles), the first addition to the original $\mathrm{EZ}$ (which made it 6.75 square miles), the third addition to the $\mathrm{EZ}$ (which made it 45.7 square miles) and the total $\mathrm{EZ}$ (referred to as the current EZ in this dissertation) compare to three comparison or control areas: (1) the Newburg area or Newburg, the control community; (2) Jefferson County outside of the Ez; and (3) Jefferson County as a whole. ${ }^{6}$ This was done to make the analysis as close to a quasi-experiment as possible using pretest (1980 Census data) and post-test (1990 Census data) times series data (Cook and Campbell, 1979).

The Newburg area was selected as a control community and is compared to all versions of the $E Z$ because it is one of the poorest areas of Jefferson County, because of its socioeconomic similarity to the EZ areas, and because Newburg received none of the economic development assistance that the EZ communities received. It would not be fair or accurate to directly compare any portion of the $\mathrm{EZ}$ to the rest of Jefferson County or to the county as a whole because of the

6 Data for each area were aggregated from census tracts that existed within each area by Dr. Ken Singleton of the University of Louisville's Urban Studies Institute. 
large differences among the three areas with respect to key socioeconomic variables. However, utilizing both the portion of Jefferson County outside of the EZ and Jefferson County as a whole as comparison communities is necessary. This is because of the need to find out whether any changes in EZ areas simply mirrored changes in the county. That is to say, by comparing the EZ to these two larger areas, one could ascertain as to whether any changes in the EZ could be ascribed to EZ economic development incentives or simply to trends that were occurring throughout the rest of Jefferson County, if not Jefferson County in its entirety. Finally, it must be pointed out that the data come from Census questionnaires administered or completed by place of

\section{residence. ${ }^{7}$}

In looking at Table 1 on the next page, one notices that between 1980 and 1990, the original EZ and the separate census tracts added during the first and second expansions of the EZ (columns 2 and 3 ) as well as the total/current EZ suffered a decline in the number of census respondents reporting an occupation (see bottom line, "N"). The comparison communities--the Newburg area, the county outside of the EZ, and the county overall--reported increases in the number of respondents reporting an occupation. For specific occupational categories, the EZ communities had the most significant declines (5\% or more) in certain occupations than

\footnotetext{
7 The data in Tables 1 through 6 differ from the Census data in the next chapter in that the Census numbers were derived by place of work. 


\begin{tabular}{|c|c|c|c|c|c|c|c|c|c|c|c|c|c|c|c|c|c|c|c|c|c|}
\hline \multicolumn{22}{|c|}{$\begin{array}{c}\text { Table } 1 \\
\text { Occupations }\end{array}$} \\
\hline \multirow{2}{*}{$\begin{array}{l}\text { OUTCOME } \\
\text { MEASURES }\end{array}$} & \multicolumn{12}{|c|}{ ENTERPRISE ZONE COWUNITIES } & \multicolumn{9}{|c|}{ COMPARISON COMUUNITIES } \\
\hline & \multicolumn{3}{|c|}{ ORIGINAL ENTERPRISE ZONE } & \multicolumn{3}{|c|}{$\begin{array}{l}\text { ENTERPRISE ZONE } \\
\text { EXPNSLION, } 1985\end{array}$} & \multicolumn{3}{|c|}{$\begin{array}{l}\text { ENTERPRISE ZONE } \\
\text { EXPANSION, } 1986\end{array}$} & \multicolumn{3}{|c|}{ TOTAL ENTERPRISE ZONES } & \multicolumn{3}{|c|}{ COMPARISON COMMUNITY } & \multicolumn{3}{|c|}{$\begin{array}{c}\text { JEFFERSON COUNTY } \\
\text { loutside } \\
\text { enterprise zone) }\end{array}$} & \multicolumn{3}{|c|}{ JEFFERSON COUNTY TOTAL } \\
\hline Executive/Admin & 3.6 & 2.8 & -0.8 & 6.1 & 3.2 & -2.9 & 4.4 & 5.4 & +1.0 & 4.4 & 5.1 & +0.7 & 8.5 & 7.3 & -1.2 & 11.3 & 12.8 & +1.5 & 10.4 & 12.0 & +1.5 \\
\hline Professional & 5.1 & 7.0 & +1.9 & 3.6 & 5.2 & +1.6 & 6.4 & 6.6 & +0.2 & 6.1 & 6.6 & +0.5 & 8.4 & 7.1 & -1.3 & 13.3 & 14.7 & +1.4 & 12.3 & 13.8 & +1.5 \\
\hline Technical & 1.4 & 1.8 & +0.4 & 1.9 & 3.2 & +1.3 & 1.9 & 3.0 & +2.1 & 1.9 & 3.0 & +1.1 & 2.7 & 3.7 & +1.0 & 2.9 & 3.8 & 0.9 & 2.7 & 3.7 & +1.0 \\
\hline Sales & 5.2 & 9.4 & +4.2 & 5.2 & 7.4 & +2.2 & 6.5 & 8.8 & +2.3 & 6.3 & 8.9 & +2.6 & 10.0 & 9.7 & -0.3 & 11.4 & 13.5 & +2.1 & 16.7 & 13.0 & 2.3 \\
\hline Admin/Clerical & 17.8 & -12.3 & -5.5 & 12.4 & 15.9 & +3.5 & 15.1 & 15.1 & 0.0 & 15.2 & 15.2 & 0.0 & 19.8 & 18.9 & -0.9 & 18.4 & 17.5 & -0.9 & 18.0 & 17.2 & -0.8 \\
\hline Private Service & 2.1 & 2.6 & +0.5 & 1.1 & 0.0 & -1.1 & 1.9 & 0.7 & -1.2 & 1.9 & 0.9 & -1.0 & 0.8 & 1.0 & +0.2 & 0.4 & 0.3 & -0.1 & 0.6 & 0.4 & -0.2 \\
\hline $\begin{array}{l}\text { Protective } \\
\text { Service }\end{array}$ & 1.3 & 2.4 & +1.1 & 0.4 & 1.6 & +1.2 & 1.7 & 1.7 & 0.0 & 1.6 & 1.8 & +0.2 & 1.1 & 1.5 & +0.4 & 1.5 & 1.5 & 0.0 & 1.5 & 1.6 & +0.1 \\
\hline Farming/Forestry & 0.8 & 0.8 & 0.0 & 0.0 & 0.0 & 0.0 & 0.6 & 0.8 & +0.2 & 0.6 & 0.8 & +0.2 & 0.4 & 0.6 & +0.2 & 0.6 & 0.8 & +0.2 & 0.6 & 0.8 & +0.2 \\
\hline Craftsmen & 8.0 & 8.6 & +0.6 & 13.2 & 17.0 & +3.8 & 10.9 & 11.6 & +0.7 & 10.7 & 11.5 & 0.8 & 10.0 & 10.0 & 0.0 & 11.5 & 10.6 & -0.9 & 11.4 & 10.7 & -0.7 \\
\hline Machine-Operators & 14.0 & 11.1 & -3.1 & 23.1 & 16.4 & -6.7 & 17.0 & 12.0 & -5.0 & 17.0 & 12.0 & -5.0 & 15.0 & 10.7 & -4.3 & 10.2 & 6.5 & -3.7 & 11.1 & 7.0 & -4.1 \\
\hline Transportation & 6.9 & 4.5 & -2.4 & 5.1 & 8.6 & +3.5 & 6.6 & 6.5 & -0.1 & 6.6 & 6.4 & -0.7 & 5.2 & 5.2 & 0.0 & 4.2 & 3.7 & -0.5 & 4.5 & 4.0 & -0.5 \\
\hline Laborers & 8.8 & 9.2 & +0.4 & 7.7 & 7.3 & -0.4 & 7.8 & 8.0 & +0.2 & 7.9 & 8.0 & +0.1 & 5.1 & 4.9 & -0.2 & 4.0 & 4.0 & 0.0 & 4.5 & 4.4 & -0.1 \\
\hline $\bar{N}$ & 3425 & 2596 & -24.2 & 1603 & 941 & -41.3 & 34227 & 31610 & -7.6 & 39255 & 35147 & -10.5 & 12284 & 12358 & +0.6 & 260113 & 280970 & +8.0 & 299363 & 316117 & +5.6 \\
\hline
\end{tabular}


did non-Ez areas (e.g., administrative and clerical, machine operators, and other services). On the other hand, when compared to the Newburg area, EZ communities did see modest increases in the percentage of its labor force working in professional, technical, sales and craftsmen occupations. Had EZ incentives been fully effective, however, one would expect to see an increase in all occupational categories as well as an expansion in the total labor force in EZ communities when compared to the Newburg area. By 1990, the Ez incentives would have been in effect for at least six and one-half years. The mediocre performance of the $\mathrm{EZ}$ when compared to the Newburg area indicates a short-run failure of the Ez to accomplish the goals of KRS 154.45.

Table 2 shows home ownership profiles and housing stock statistics for the EZ areas and the four control areas. The numbers do not reflect favorably upon the EZ when compared to the three control and comparison areas. In regard to total occupied housing, owner occupied housing, and renter occupied housing, the EZ communities show percentage decreases in all these areas. There were also declines in both white and black occupied households as well as a decline in overall housing stock for all EZ communities. These numbers seem to support the fact that western, southern and southwestern Jefferson County lost population during the 1980s (Coomes and Price, 1994).

Jefferson County outside of the EZ as well as Jefferson County overall show the reverse of EZ trends during the 1980s. 
Table 2

Housing Ownership Profiles

\begin{tabular}{|c|c|c|c|c|c|c|c|c|c|c|c|c|c|c|c|c|c|c|c|c|c|}
\hline \multirow{3}{*}{$\begin{array}{l}\text { OUTCOME } \\
\text { MEASURES }\end{array}$} & \multicolumn{12}{|c|}{ ENTERPRISE ZONE COWUNITIES } & \multicolumn{9}{|c|}{ COMPARISON COMMUNITIES } \\
\hline & \multicolumn{3}{|c|}{ ORIGINAI ENTERPRISE ZONE } & \multicolumn{3}{|c|}{$\begin{array}{l}\text { ENTERPRISE ZONE } \\
\text { EXPANSION, } 1985\end{array}$} & \multicolumn{3}{|c|}{$\begin{array}{l}\text { ENTERPRISE ZONE } \\
\text { EXPANSION, } 1986\end{array}$} & \multicolumn{3}{|c|}{ TOTAL ENTERPRISE ZONES } & \multicolumn{3}{|c|}{ COMPARISON COASUNITY } & \multicolumn{3}{|c|}{ 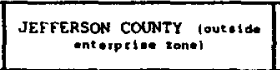 } & \multicolumn{3}{|c|}{ JETEERSON COUNTY TOTNL } \\
\hline & 1980 & 1990 & 8 & 1980 & 1990 & 8 & 1980 & 1990 & 8 & 1980 & 1990 & 8 & 1980 & 1990 & ? & 1980 & 1990 & $\$$ & 1980 & 1990 & t \\
\hline Housing Stock & 5586 & 4733 & -18.3 & 1671 & 1058 & -36.7 & 39303 & 36757 & -6.5 & 46560 & 42548 & -8.6 & 10940 & 11579 & +5.8 & 219222 & 240030 & +9.5 & 265782 & 282578 & +6.3 \\
\hline $\begin{array}{l}\text { Total Occupied } \\
\text { Housing }\end{array}$ & 5043 & 4173 & -17.8 & 2586 & 893 & -43.7 & 35618 & 32733 & -9.5 & 42247 & 37269 & -11.3 & 9930 & 10762 & +8.4 & 205322 & 226869 & +8.9 & 250569 & 264178 & +5.4 \\
\hline $\begin{array}{l}\text { Owner Occupied } \\
\qquad \text { white } \\
\text { Black }\end{array}$ & $\begin{array}{l}1526 \\
n / a \\
n / a\end{array}$ & $\begin{array}{l}1088 \\
59.1 \\
40.1\end{array}$ & -28.7 & $\begin{array}{l}1047 \\
\mathrm{n} / \mathrm{a} \\
\mathrm{n} / \mathrm{a}\end{array}$ & $\begin{array}{c}482 \\
90.0 \\
9.1\end{array}$ & -54.0 & $\begin{array}{l}18900 \\
n / a \\
n / a\end{array}$ & $\begin{array}{l}16968 \\
55.6 \\
44.4\end{array}$ & -10.2 & $\begin{array}{c}21473 \\
n / a \\
n / a\end{array}$ & $\begin{array}{l}18538 \\
38.2 \\
60.3\end{array}$ & -13.7 & $\begin{array}{l}4940 \\
n / a \\
n / a\end{array}$ & $\begin{array}{l}4918 \\
65.3 \\
34.5\end{array}$ & -0.4 & $\begin{array}{c}143996 \\
n / a \\
n / a\end{array}$ & $\begin{array}{c}151852 \\
92.9 \\
6.4\end{array}$ & +5.4 & $\begin{array}{c}165469 \\
n / a \\
n / a\end{array}$ & $\begin{array}{l}170390 \\
89.0 \\
10.4\end{array}$ & +2.9 \\
\hline $\begin{array}{l}\text { Renter Occupied } \\
\text { white } \\
\text { Black }\end{array}$ & $\begin{array}{l}3517 \\
n / a \\
n / a\end{array}$ & $\begin{array}{l}3055 \\
12.8 \\
86.9 \\
\end{array}$ & -13.1 & $\begin{array}{l}539 \\
n / a \\
n / a\end{array}$ & $\begin{array}{c}411 \\
93.7 \\
5.1 \\
\end{array}$ & -23.7 & $\begin{array}{c}16718 \\
n / a \\
n / a\end{array}$ & $\begin{array}{c}25265 \\
41.7 \\
56.5 \\
\end{array}$ & -8.7 & $\begin{array}{c}20774 \\
n / a \\
n / a\end{array}$ & $\begin{array}{c}18731 \\
38.2 \\
60.3 \\
\end{array}$ & -9.8 & $\begin{array}{l}4990 \\
n / a \\
n / a\end{array}$ & $\begin{array}{l}5844 \\
53.5 \\
45.3 \\
\end{array}$ & +17.1 & $\begin{array}{c}64326 \\
n / a \\
n / a\end{array}$ & $\begin{array}{l}75017 \\
81.7 \\
17.2 \\
\end{array}$ & +16.6 & $\begin{array}{c}85100 \\
n / a \\
n / a\end{array}$ & $\begin{array}{l}93748 \\
73.0 \\
25.8 \\
\end{array}$ & +10.2 \\
\hline $\begin{array}{l}\text { White Occupied } \\
\text { owners } \\
\text { Renters }\end{array}$ & $\begin{array}{l}1517 \\
n / a \\
n / a\end{array}$ & $\begin{array}{l}1033 \\
62.2 \\
37.8\end{array}$ & -31.9 & $\begin{array}{l}1451 \\
n / a \\
n / a\end{array}$ & $\begin{array}{l}819 \\
53.0 \\
47.0\end{array}$ & -43.6 & $\begin{array}{c}18419 \\
n / a \\
n / a\end{array}$ & $\begin{array}{c}15798 \\
59.7 \\
40.3\end{array}$ & -14.2 & $\begin{array}{c}21387 \\
n / a \\
n / a\end{array}$ & $\begin{array}{l}17650 \\
59.5 \\
40.5\end{array}$ & -17.5 & $\begin{array}{l}6717 \\
n / a \\
n / a\end{array}$ & $\begin{array}{l}6339 \\
50.7 \\
49.3 \\
\end{array}$ & & $\begin{array}{c}190582 \\
n / a \\
n / a\end{array}$ & $\begin{array}{c}202435 \\
69.7 \\
30.3\end{array}$ & +6.2 & $\begin{array}{c}211969 \\
n / a \\
n / a\end{array}$ & $\begin{array}{c}220085 \\
68.9 \\
31.1\end{array}$ & +3.8 \\
\hline $\begin{array}{c}\text { Black Occupied } \\
\text { Owners } \\
\text { Renters }\end{array}$ & $\begin{array}{l}3515 \\
n / a \\
n / a\end{array}$ & $\begin{array}{l}3099 \\
14.4 \\
85.6\end{array}$ & -11.8 & $\begin{array}{l}127 \\
n / a \\
n / a\end{array}$ & $\begin{array}{c}65 \\
67.7 \\
32.3 \\
\end{array}$ & -48.8 & $\begin{array}{c}17004 \\
n / a \\
n / a\end{array}$ & $\begin{array}{l}16091 \\
46.4 \\
53.6\end{array}$ & -5.3 & $\begin{array}{c}20646 \\
n / a \\
n / a\end{array}$ & $\begin{array}{l}19255 \\
41.3 \\
58.7\end{array}$ & -6.7 & $\begin{array}{l}3106 \\
n / a \\
n / a\end{array}$ & $\begin{array}{l}4344 \\
39.0 \\
61.0\end{array}$ & +39.2 & $\begin{array}{c}16250 \\
n / a \\
n / a\end{array}$ & $\begin{array}{c}22698 \\
43.1 \\
56.9 \\
\end{array}$ & +39.7 & $\begin{array}{c}36896 \\
n / a \\
n / a\end{array}$ & $\begin{array}{l}41953 \\
42.3 \\
57.7\end{array}$ & +13.7 \\
\hline $\begin{array}{l}\text { 8lack Occupied } \\
\text { Housing }\end{array}$ & 69.7 & 74.8 & +5.1 & 8.0 & 7.3 & -0.7 & 47.7 & 49.9 & +2.2 & 48.9 & 51.7 & +2.8 & 31.3 & 40.4 & +9.1 & 7.8 & 10.0 & +2.2 & 14.7 & 15.9 & +1.2 \\
\hline twOTr: : 10 rav chan & chere & & inge 1 & & $\cdots$ & 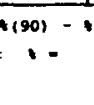 & 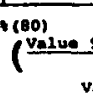 & value ac & e0) & $\times 100$ & & & & & & & & & & & \\
\hline
\end{tabular}


The Newburg area, despite being considered a depressed area, showed an increase in total occupied housing, renter occupied housing, black occupied housing, and an increase in the overall housing stock. The amount of owner-occupied housing in this area remained virtually the same between 1980 and 1990, although the area did see less white occupied housing than it did in 1980. Therefore, the EZ failed to see improvements in home ownership and neighborhood revitalization despite program incentives, whereas the Newburg area, which did not receive the EZ economic development stimulus, faired much better.

Table 3 shows that housing conditions in all EZ communities were, in general, either inferior to those of the Newburg area and comparison communities or basically the same. The percentage of housing units vacant is somewhat higher in the EZ areas than in the others, and the EZ areas have older housing stock than their control and comparison counterparts. Most of the EZ housing stock was built before 1940 whereas most of the control and comparison communities housing stock was built from 1960-69. Reflecting the older (and perhaps less desirable) housing stock in the EZ areas, average housing values are lower in EZ areas than in the comparison communities. Also, for the current EZ or total Enterprise Zone, housing values appreciated $51.1 \%$ between 1980 and 1990 whereas Newburg was not far behind at $43.9 \%$. The rest of Jefferson County and the county as a whole experienced greater home value appreciation (62.7\% and $64 \%$, respectively) during 


\begin{tabular}{|c|c|c|c|c|c|c|c|c|c|c|c|c|c|c|c|c|c|c|c|c|c|}
\hline \multicolumn{22}{|c|}{ Housing Conditions } \\
\hline \multirow{2}{*}{$\begin{array}{c}\text { OOTCONE } \\
\text { MEASURES }\end{array}$} & \multicolumn{3}{|c|}{ onsersue ameronst zome } & \multicolumn{3}{|c|}{ 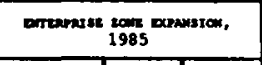 } & \multicolumn{3}{|c|}{ 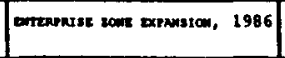 } & \multicolumn{3}{|c|}{ 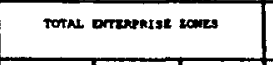 } & \multicolumn{3}{|c|}{ 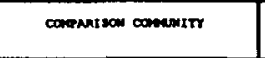 } & \multicolumn{3}{|c|}{$\begin{array}{l}\text { Jernasow cowry loutside } \\
\text { onterprise zone) }\end{array}$} & \multicolumn{3}{|c|}{ Jertensom coumrtr torat } \\
\hline & 1980 & 1990 & 1 & 1980 & 1990 & 1 & 1980 & 1990 & 1 & 1980 & 2990 & 1 & 1980 & 1990 & 1 & 1980 & 1990 & 1 & 1980 & 1990 & 1 \\
\hline I Rentals & 69.7 & 73.7 & +4.0 & 34.0 & 16.0 & +12.0 & 16.9 & 45.3 & -1.6 & 19.2 & 50.3 & +1.1 & 50.3 & 54.3 & +4.0 & 30.9 & 38.7 & .2 .2 & 34.0 & 35.5 & +1.5 \\
\hline I Public Water & 99.9 & 99.5 & -0.4 & 100.0 & 100.0 & 0.0 & 99.1 & 99.5 & +0.4 & 99.3 & 99.5 & +0.7 & 100.0 & 99.9 & -0.1 & 99.7 & 98.3 & +0.6 & 98.0 & 98.5 & +0.5 \\
\hline I without Heat & 4.2 & $0.9^{\circ}$ & -3.5 & 0.0 & 0.0 & 0.0 & 1.7 & 1.2 & -0.5 & 2.0 & 1.1 & -0.9 & 0.0 & 0.2 & +0.2 & 1.1 & 0.2 & +0.9 & 1.3 & 0.3 & -1.0 \\
\hline Incomplete Kitchens & 2.2 & 2.3 & +0.2 & 0.4 & 0.0 & -0.4 & 2.2 & 2.1 & -0.1 & 2.2 & 2.1 & -0.1 & 1.0 & 0.8 & -0.2 & 1.1 & 0.5 & -0.6 & 3.3 & 0.7 & -0.6 \\
\hline I No Telephone & 17.6 & 23.5 & 5.9 & 6.9 & 12.3 & +5.4 & 12.8 & 13.0 & +0.2 & 13.1 & 14.2 & +1.1 & 7.4 & 7.2 & -0.2 & 3.9 & 3.1 & -0.5 & 5.5 & 4.9 & -0.6 \\
\hline Incomplete plumbing & 1.2 & 1.0 & -0.2 & 1.2 & 1.0 & -0.2 & 2.2 & 1.1 & -1.1 & 1.7 & 1.1 & -0.6 & 0.5 & 0.7 & +0.2 & 0.7 & 0.3 & -0.1 & 0.9 & 0.1 & -0.5 \\
\hline I No Bedroom & 2.0 & 2.5 & 0.5 & 0.0 & 0.0 & 0.0 & 1.2 & 2.3 & +1.1 & 1.3 & 2.2 & +0.9 & 0.6 & 1.5 & 0.9 & 1.0 & 1.2 & 40.2 & 1.1 & 2.4 & .0 .3 \\
\hline I One Bedroom or Less & 36.1 & 34.5 & -1.6 & 20.2 & 17.3 & -2.9 & 26.5 & 23.3 & -3.2 & 27.4 & 24.4 & -3.0 & 22.5 & 23.7 & .0 .8 & 15.3 & 16.4 & -0.9 & 17.4 & 15.9 & -1.5 \\
\hline $\begin{array}{l}\text { Period Most Housing } \\
\text { Bullt }\end{array}$ & $84-40$ & $84-40$ & & B4-40 & B1-40 & & $84-40$ & B4-40 & & $60-69$ & $60-69$ & & $60-69$ & $60-69$ & & $60-69$ & $60-69$ & & $60-69$ & $60-69$ & \\
\hline D Bullt before 1940 & 11.9 & 29.4 & -12.5 & 52.0 & 53.7 & +1.7 & 15.3 & 38.4 & -6.9 & 15.0 & 37.7 & -7.3 & 2.4 & 1.4 & -1.0 & 17.9 & 15.1 & -2.8 & 22.7 & 18.5 & -4.2 \\
\hline Avg. House value & $\$ 16571$ & $\$ 26951$ & +62.1 & $\$ 26009$ & $\$ 50316$ & +93.5 & 519883 & $\$ 29840$ & +50.1 & 519971 & $\$ 30180$ & +51.1 & 531333 & $\$ 45084$ & .43 .9 & $\$ 45885$ & 574670 & .62 .7 & 542647 & $\$ 69949$ & +60.0 \\
\hline $\begin{array}{l}\text { Avg. Gross Rent } \\
\text { (uti1ities included) }\end{array}$ & $\$ 100$ & $\$ 174$ & +74.0 & $s 171$ & $\$ 313$ & +83.0 & 5161 & $\$ 281$ & +74.5 & 5151 & $\$ 260$ & +74.8 & $\$ 232$ & $\$ 376$ & +62.1 & $\$ 228$ & 5384 & +68.2 & $\$ 209$ & $\$ 361$ & +72.7 \\
\hline 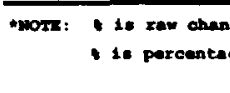 & & & & & & & 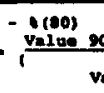 & & & & & & & & & & & & & & \\
\hline
\end{tabular}


this same period. Therefore, appreciation in housing values was pretty much a common trend throughout most of the county during the 1980 s with the EZ neighborhoods being no exception. With this in mind, the ability of $\mathrm{EZ}$ incentives to raise residential wealth and to revive neighborhoods is very doubtful.

One unusual number appearing in the table is the increase of $93.5 \%$ in the value of houses in the census tracts taken in during the first EZ expansion. Perhaps one explanation for this unusual climb in value is due to the condemnation and removal of several lower middle class and lower income neighborhoods during the late 1980 s and early 1990 s in order to expand Standiford Field, now known as Louisville International Airport. ${ }^{8}$ If mostly higher priced homes were left remaining in these tracts, then that would explain such a large jump in average house value between 1980 and 1990. Recall that the first line of Table 2 showed a $36.7 \%$ decline in the housing stock of this area and that the second line of Table 2 showed a $42.7 \%$ decline in occupied housing for these tracts between 1980 and 1990. This aberration could skew the results for the full-size Ez by helping to overstate the rate of home appreciation for the full-size EZ. Appreciation for the full-size EZ may have actually been less than $51.1 \%$

Note that all four columns under Enterprise zone

8 According to Professor John P. Nelson of the Urban Studies Institute, the demolition of Louisville's Highland Park neighborhood began in early 1989 and was nearly finished by 
Communities in Table 3 show increases in the percentage of households without telephones whereas the comparison communities show decreases in this same indicator of substandard living conditions. If owning a telephone is considered a basic component of "quality of life" then the EZ experiment did not seem to accomplish the goal of increasing the quality of life for EZ residents during most of the 1980 s. Table 4 is perhaps the most telling table of this chapter in regard to EZ incentives and EZ performance during the 1980s. Note that while comparison communities lost population during this time period, the loss of population within the EZ communities was even greater.

In looking at the category of education one can see one of the possible reasons why the EZ area was at a comparative disadvantage relative to the control/comparison communities. Between 1980 and 1990, the percentage of high school and college educated people living within the EZ communities went up. Yet, the percentage of those with at least a high school diploma or college degree was still well below that of the control or comparison communities. For example, during the 1980s, the full-size EZ saw an increase in the percentage of its population of high school graduates from $44.5 \%$ to $54.7 \%$ and saw an increase in the percentage of its population of college graduates from $3.6 \%$ to $4.9 \%$. However, each control area had an even higher level of its population classified as high school or college

the time of the 1990 Census. 
Table 4

Demographics and Education

\begin{tabular}{|c|c|c|c|c|c|c|c|c|c|c|c|c|c|c|c|c|c|c|c|c|c|}
\hline \multirow{2}{*}{$\begin{array}{l}\text { OUTCOME } \\
\text { MEASURES }\end{array}$} & \multicolumn{12}{|c|}{ ENTERPRISE ZONE COMUNITIES } & \multicolumn{9}{|c|}{ COMPARISON COMMUNITIES } \\
\hline & \multicolumn{3}{|c|}{ ORIGINAS ENTERPRISE ZONE } & \multicolumn{3}{|c|}{$\begin{array}{l}\text { ENTERPHISE ZONE } \\
\text { EXPANSION, } 1985\end{array}$} & \multicolumn{3}{|c|}{$\begin{array}{l}\text { ENTERPRISE } 2 \text { 2ONE } \\
\text { EXPANSION, } 1986\end{array}$} & \multicolumn{3}{|c|}{ TOTAL ENTERPRISE ZONES } & \multicolumn{3}{|c|}{ COMPARISON COREUNITY } & \multicolumn{3}{|c|}{ 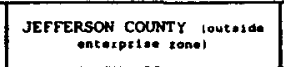 } & \multicolumn{3}{|c|}{ JEFFERSON COUNTY TOTAS } \\
\hline Population & 13247 & 10877 & -17.9 & 3990 & 2303 & -42.3 & 101265 & 86844 & -42.3 & 118502 & 100024 & -15.6 & 26719 & 26439 & -1.0 & 566502 & 564913 & -0.3 & 685004 & 664937 & -2.9 \\
\hline White & 3789 & 2766 & -27.0 & 3713 & 2702 & -44.2 & 50652 & 41710 & -17.7 & 58154 & 46458 & -20.0 & 16111 & 13585 & -15.7 & 511522 & 497853 & -2.7 & 569676 & 544401 & -4.4 \\
\hline Black & 9398 & 8079 & -14.0 & 246 & 183 & -25.6 & 49943 & 43884 & -12.1 & 59587 & 52146 & -12.5 & 10350 & 12581 & +21.6 & 50340 & 61134 & +21.4 & 109927 & 113280 & +3.1 \\
\hline \multicolumn{22}{|l|}{$\begin{array}{l}\text { Age } \\
\text { Distribution }\end{array}$} \\
\hline $0-16$ & 36.1 & 36.7 & +0.6 & 22.5 & 23.5 & +1.0 & 29.3 & 27.3 & -2.0 & 29.9 & 28.3 & -1.6 & 27.6 & 25.8 & -1.8 & 25.0 & 22.2 & -2.8 & 25.9 & 23.1 & -2.8 \\
\hline $17-24$ & 14.7 & 12.0 & -2.7 & 13.6 & 10.9 & -2.7 & 16.4 & 13.1 & -3.3 & 16.1 & 12.9 & -3.2 & 18.5 & 14.1 & -4.4 & 14.5 & 10.5 & -4.0 & 14.7 & 10.8 & -3.9 \\
\hline $25-34$ & 12.8 & 14.6 & +1.8 & 12.1 & 19.9 & +7.8 & 14.3 & 17.0 & +2.7 & 14.0 & 16.3 & +2.8 & 18.7 & 18.6 & -0.1 & 17.5 & 17.7 & +0.2 & 16.9 & 17.5 & +0.6 \\
\hline $35-54$ & $14.6^{\circ}$ & 18.9 & +4.3 & 22.8 & 22.4 & -0.4 & 18.9 & 21.8 & +2.9 & 18.5 & 21.5 & +3.0 & 23.9 & 27.8 & +3.9 & 22.2 & 26.4 & +4.2 & 21.6 & 25.7 & +4.1 \\
\hline $55-64$ & 9.7 & 7.4 & -2.3 & 13.2 & 10.2 & -3.0 & 9.1 & 8.6 & -0.5 & 9.3 & 8.5 & -0.0 & 10.4 & 10.7 & +0.3 & 10.0 & 9.5 & -0.5 & 9.9 & 9.4 & +0.5 \\
\hline $65-76$ & 8.0 & 8.0 & 0.0 & 10.0 & 7.0 & -3.0 & 7.3 & 7.1 & -0.2 & 7.4 & 7.1 & -0.3 & 5.1 & 8.8 & +3.7 & 6.6 & 8.0 & +1.4 & 6.7 & 7.9 & +1.2 \\
\hline \multicolumn{22}{|l|}{ Education } \\
\hline $\begin{array}{l}\text { High } \\
\text { School }\end{array}$ & 40.9 & 43.5 & +2.6 & 42.0 & 53.8 & +11.8 & 45.0 & 55.9 & +70.9 & 44.5 & 54.7 & +10.2 & 67.8 & 72.2 & +4.4 & 69.3 & 77.7 & +3.4 & 65.2 & 74.5 & +9.3 \\
\hline Grad College & 2.6 & 1.7 & -0.9 & 2.5 & 6.3 & +3.8 & 3.8 & 5.2 & +1.4 & 3.6 & 4.9 & +1.3 & 9.4 & 8.5 & -0.9 & 15.3 & 20.0 & +4.2 & 13.8 & 17.9 & +4.1 \\
\hline \multicolumn{22}{|l|}{ Sex } \\
\hline Male & 43.2 & 43.9 & +0.7 & 49.0 & 48.1 & -0.9 & 46.9 & 47.5 & +0.6 & 46.6 & 47.1 & +0.5 & 46.8 & 45.8 & -1.0 & 47.7 & 47.3 & -0.4 & 47.5 & 47.2 & -0.3 \\
\hline Female & 56.8 & 56.1 & -0.7 & 51.0 & 51.9 & +0.9 & 53.1 & 52.5 & -0.6 & 53.4 & 52.9 & -0.5 & 53.2 & 54.2 & -0.5 & 52.3 & 52.7 & +0.4 & 52.5 & 52.8 & +0.3 \\
\hline
\end{tabular}

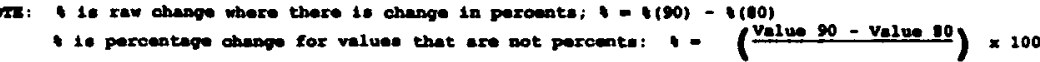


graduates in both 1980 and 1990. In fact, even though the EZ saw an improvement in its "human capital" (more high school and college graduates living in the area), all of the control communities experienced increases as well. These areas were already ahead of the $E 2$ in human capital in 1980 and had stayed ahead by 1990.

With regard to unemployment, Table 5 shows that although unemployment declined throughout most of the $\mathrm{EZ}$ and comparison communities during the 1980s, the overall level of unemployment in percentage terms was still higher in the EZ areas than in the control areas as of 1990. This was pretty much the case whether one was black or white, male or female. The highest levels of unemployment still exist in the original EZ area, the area that was initially targeted for urban redevelopment. For all EZ areas, their unemployment rates of 1990 were still anywhere from one and one-half times to three times the rate of those in the comparison communities despite drops in the unemployment rates from 1980 to 1990. However, the decreases in the unemployment rates in the $\mathrm{EZ}$ communities were not that different in magnitude than those in the comparison/control communities.

Finally, Table 6 shows that while average household and family income rose in the Ez communities, the rates of increase for the comparison communities were even higher. Not only that, but EZ communities were behind their counterparts 


\section{Table 5}

Unemployment statistics

\begin{tabular}{|c|c|c|c|c|c|c|c|c|c|c|c|c|c|c|c|c|c|c|c|c|c|}
\hline \multirow{3}{*}{$\begin{array}{c}\text { OUTCOAE } \\
\text { MEASURES }\end{array}$} & \multicolumn{12}{|c|}{ EMTERPRISE ZONE COAUNITIES } & \multicolumn{9}{|c|}{ COMPARISON CONANITIES } \\
\hline & \multicolumn{3}{|c|}{ ORIGIMAL ENTERPRISE zONE } & \multicolumn{3}{|c|}{$\begin{array}{l}\text { DrTERPRISE zONE } \\
\text { EXPANSION, } 1985\end{array}$} & \multicolumn{3}{|c|}{$\begin{array}{l}\text { ENreaprise zOWE } \\
\text { EXPANSICN, } 1986\end{array}$} & \multicolumn{3}{|c|}{ TOTNL ENTERPRISE ZONES } & \multicolumn{3}{|c|}{ COMPARISON COHANITY } & \multicolumn{3}{|c|}{ 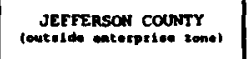 } & \multicolumn{3}{|c|}{ JEFRERSON COUNTY TOTAL } \\
\hline & 1980 & 1990 & 1 & 1980 & 1990 & 1 & 1980 & 1990 & 1 & 1980 & 1990 & 1 & 1980 & 1990 & 1 & 1980 & 1990 & 1 & 1980 & 1990 & 1 \\
\hline Unemployment Rate & 26.1 & 22.9 & -3.2 & 7.6 & 8.3 & +0.7 & 15.2 & 13.0 & -2.2 & 16.3 & 13.7 & -2.6 & 8.7 & 8.1 & -0.3 & 6.6 & 5.1 & -1.5 & 7.9 & 6.1 & -1.8 \\
\hline Males & 27.1 & 23.0 & -4.1 & 10.3 & 7.3 & -2.5 & 15.7 & 12.8 & -2.9 & 16.5 & 13.5 & -3.0 & 9.4 & 9.1 & -0.3 & 6.9 & 5.4 & -1.5 & 8.3 & 6.3 & -2.0 \\
\hline Females & 25.5 & 22.8 & -2.7 & 3.6 & 9.0 & +5.4 & 14.8 & 13.2 & -1.6 & 16.0 & 14.0 & -2.0 & 7.9 & 7.9 & 0.0 & 6.3 & 4.8 & -1.5 & 7.5 & 5.9 & -1.6 \\
\hline White Unemployment & 11.7 & 36.1 & +4.4 & 9.2 & 6.6 & -2.6 & 11.6 & 8.7 & -2.9 & 11.6 & 9.0 & -2.6 & 6.6 & 5.7 & -0.9 & 6.2 & 4.5 & -1.7 & 6.6 & 4.8 & -1.8 \\
\hline Males & 15.0 & 18.3 & +3.3 & 11.8 & 4.0 & -7.8 & 12.2 & 8.9 & -3.3 & 12.3 & 9.2 & -3.1 & 7.3 & 6.0 & -1.3 & 6.5 & 4.8 & -1.7 & 6.9 & 5.1 & -1.8 \\
\hline Eemales & 6.0 & 13.1 & +7.1 & 4.7 & 9.4 & +4.7 & 10.8 & 8.4 & -2.4 & 10.4 & 8.7 & -1.7 & 5.7 & 5.4 & -0.3 & 5.8 & 4.2 & -1.6 & 6.1 & 4.5 & -1.6 \\
\hline Black Onemployment & 30.2 & 26.5 & -3.7 & $0.0^{*}$ & 31.1 & +31.1 & 19.3 & 17.5 & -1.8 & 20.9 & 18.5 & -2.4 & 11.8 & 11.7 & -0.1 & 11.9 & 10.3 & -1.6 & 16.2 & 13.6 & -2.6 \\
\hline Males & 32.8 & 26.7 & -6.1 & 0.0 & 44.2 & +44.2 & 20.1 & 17.8 & -2.3 & 21.6 & 18.3 & -2.3 & 14.1 & 13.5 & -0.6 & 12.7 & 11.6 & -1.1 & 16.9 & 14.5 & -2.1 \\
\hline Females & 28.6 & 26.4 & -2.2 & 0.0 & 0.0 & 0.0 & 18.4 & 17.2 & -1.2 & 20.3 & 18.3 & -2.0 & 9.9 & 10.3 & +0.4 & 11.1 & 9.2 & -1.9 & 16.5 & 12.8 & -2.7 \\
\hline
\end{tabular}

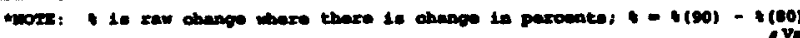

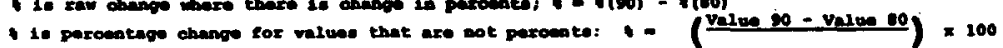

valus 10 
in both 1980 and 1990 when it came to the levels of household and family income. Poverty was worse in the EZ communities in 1980 than in the comparison communities and grew worse during the $1980 \mathrm{~s}$ as the 1990 census data show. The comparison communities only showed negligible increases in poverty during the 1980s (with the exception of Bluegrass) whereas the EZ areas showed larger gains in poverty on average.

In general, Table 6 points out that the EZ communities saw their civilian labor force shrink significantly in comparison to the control communities. Not only did work seem to disappear from these areas but so did workers. Finally, Table 6 shows that the EZ communities had both in 1980 and 1990 a much higher proportion of their population not in the labor force than in the control areas. These six tables do not indicate that any real neighborhood revitalization was taking place in the Ez communities by 1990. In many ways, according to Census data, the EZ communities had fallen behind their non-EZ counterparts. These results imply that EZ incentives were not working as far as helping these targeted areas to grow and prosper much less helping them to hold their own against further decline. 


\begin{tabular}{|c|c|c|c|c|c|c|c|c|c|c|c|c|c|c|c|c|c|c|c|c|c|}
\hline \multicolumn{22}{|c|}{$\begin{array}{l}\text { Table } 6 \\
\text { Economic }\end{array}$} \\
\hline \multirow{3}{*}{ 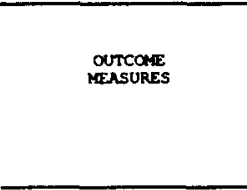 } & \multicolumn{12}{|c|}{ 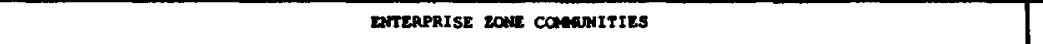 } & \multicolumn{9}{|c|}{ COMPARISON COEAOUITIES } \\
\hline & \multicolumn{3}{|c|}{ 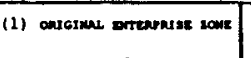 } & \multicolumn{3}{|c|}{ 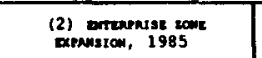 } & \multicolumn{3}{|c|}{ 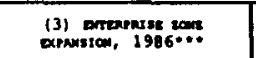 } & \multicolumn{3}{|c|}{ Totre Drevernse some". } & \multicolumn{3}{|c|}{ conovisson comesitr } & \multicolumn{3}{|c|}{$\begin{array}{l}\text { Jerreseow courrt (outside } \\
\text { enterprise zone) }\end{array}$} & \multicolumn{3}{|c|}{ Jerteseow contr totN } \\
\hline & 1980 & 1990 & . & 1980 & 1990 & . & 1980 & 1990 & . & 1980 & 2990 & 1 & 1980 & 1990 & 1 & 1980 & 1990 & 1 & 1980 & 1990 & 1 \\
\hline Avg Housenold Income & 8296 & 11132 & +34.2 & 14710 & 21605 & +46.9 & 12290 & 19849 & +61.8 & 21897 & 18913 & .59 .0 & 16935 & 23987 & +41.6 & 21497 & 37715 & +75.4 & 19879 & 35079 & +76.5 \\
\hline Avg Fanily income & 9354 & 12734 & +36.1 & 16850 & 25851 & .53 .4 & 11290 & 22621 & +50.3 & 13820 & 21635 & .56 .6 & 18613 & 27353 & +47.0 & 24609 & 44162 & +79.5 & 22894 & 41096 & +79.5 \\
\hline - Below Poverty Line & 8.8 & 64.4 & +16.4 & 17.0 & 26.3 & +9.3 & 28.9 & 34.3 & +5.1 & 30.8 & 37.4 & +6.6 & 14.9 & 23.4 & +8.5 & 8.3 & 9.9 & +1.6 & 12.2 & 14.0 & +1.0 \\
\hline $\begin{array}{l}\text { Below } 751 \text { of Poverty } \\
\text { in ne }\end{array}$ & 39.3 & 55.4 & .16 .1 & 10.9 & 22.2 & +11.3 & 21.3 & 26.2 & +4.9 & 23.0 & 29.3 & +6.3 & 10.6 & 16.8 & .6 .2 & 5.7 & 5.9 & +1.2 & 8.6 & 10.0 & +1.4 \\
\hline $\begin{array}{l}\text { I Female Headed } \\
\text { Households with } \\
\text { Dependent Children }\end{array}$ & 15.2 & 12.2 & -3.0 & 4.9 & 16.1 & +11.2 & 21.6 & 17.8 & -3.8 & 23.7 & 20.2 & -3.5 & 28.5 & 18.3 & -0.2 & 8.1 & 7.8 & -0.3 & 10.6 & 9.6 & -1.0 \\
\hline Civilien Lebor force & 4393 & 3621 & -23.4 & 1728 & 1026 & -40.6 & 60285 & 36331 & -9.8 & 16406 & 40721 & -12.3 & 13453 & 13499 & $\cdot 0.3$ & 278663 & 296043 & +6.2 & 325069 & 336764 & .3 .9 \\
\hline $\begin{array}{l}\text { Potential Civic Labor } \\
\text { Force }\end{array}$ & 8730 & 7024 & -19.0 & 3122 & 2765 & -43.5 & 13501 & 64121 & -12.4 & 85353 & 73260 & -14.2 & 19395 & 19946 & +0.3 & 434905 & 146915 & .2 .8 & 520528 & 520175 & -0.0 \\
\hline $\begin{array}{l}\text { Females in Labor rorce } \\
\text { (11) }\end{array}$ & $\begin{array}{l}2323 \\
(52.9)\end{array}$ & $\begin{array}{l}1839 \\
154.71)\end{array}$ & $\begin{array}{c}-20.8 \\
010.81\end{array}$ & $\begin{array}{c}699 \\
(39.9)\end{array}$ & $\begin{aligned} & 469 \\
& 145.71\end{aligned}$ & $\begin{array}{r}-31.9 \\
(+5.6)\end{array}$ & $\begin{array}{r}28123 \\
145.71\end{array}$ & $\begin{array}{l}17537 \\
(48.3)\end{array}$ & $\begin{array}{r}-4.9 \\
(+2.6)\end{array}$ & $\begin{array}{l}21435 \\
(16.2)\end{array}$ & $\begin{array}{l}19945 \\
(18.7)\end{array}$ & $(+2.5)$ & $\begin{array}{l}6435 \\
(17.8)\end{array}$ & $\begin{array}{r}7016 \\
(32.8)\end{array}$ & $1+9.04$ & $\begin{array}{l}121036 \\
(43.4)\end{array}$ & $\begin{array}{l}110555 \\
(197.5)\end{array}$ & ite.i1) & $\begin{array}{r}142471 \\
(43.3)\end{array}$ & $\begin{array}{l}160400 \\
(47.6)\end{array}$ & $\begin{array}{r}+12.6 \\
(+3.8) \\
+3\end{array}$ \\
\hline $\begin{array}{l}\text { Males not in Labor } \\
\text { Force in the Potential } \\
\text { Labor Force }\end{array}$ & 39.4 & 15.9 & +6.5 & 30.3 & 32.4 & +2.1 & 34.8 & 36.8 & +2.0 & 35.1 & 37.5 & +2.4 & 22.3 & 25.9 & +3.6 & 22.0 & 24.4 & +2.1 & 24.1 & 26.2 & +2.1 \\
\hline $\begin{array}{l}\text { Femalas not in Labor } \\
\text { Force in the potential } \\
\text { Labor Force }\end{array}$ & 56.2 & 56.2 & 0.0 & 37.9 & 50.0 & -7.9 & 33.7 & 49.2 & -4.5 & 54.1 & 50.0 & -4.1 & 10.6 & 37.0 & -3.6 & 47.8 & 41.6 & -6.2 & 48.9 & 42.8 & -6.1 \\
\hline \multicolumn{22}{|c|}{ 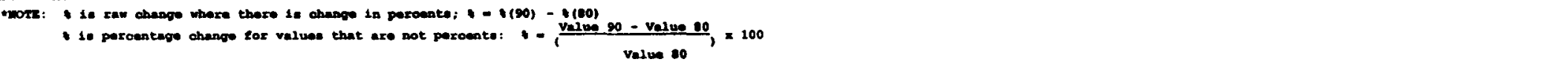 } \\
\hline \#\#gum of fixat throe & & & & & & & & & & & & & & & & & & & & & \\
\hline
\end{tabular}




\section{Evaluating Neighborhood Revitalization using Home Mortgage Disclosure Act Data}

In compliance with the Community Reinvestment Act of 1977 and the Home Mortgage Disclosure Act of 1975, the St. Louis Federal Reserve Branch releases on an annual basis data that show home mortgage lending patterns down to the census tract level within Jefferson County. This data goes back to 1981 with the most recent set of data released in 1994 . It was hypothesized that if $\mathrm{EZ}$ incentives had led to neighborhood revitalization in targeted areas, then one would find that home mortgage lending rates for the $\mathrm{EZ}$ areas would at least match if not exceed those in the control communities, and that the average dollar amounts for such loans would at least be equal to those in the control communities. If EZ communities were blighted and needed a massive rebuilding effort, then the data from the St. Louis Federal Reserve District should show that home building and construction should have taken off after KRS 154.45 was passed in 1982. Two of the goals of the legislation and the incentives embodied in KRS 154.45 were to "[I]mprove the quality of life of individuals that reside within an enterprise zone by providing employment opportunities, job training, and neighborhood improvement programs" and to "[E]liminate blighted and deteriorated areas within an enterprise zone that feature chronic abandonment or demolition of residential or commercial structures or property" (KRS 154.45, p. 412, emphasis added). 


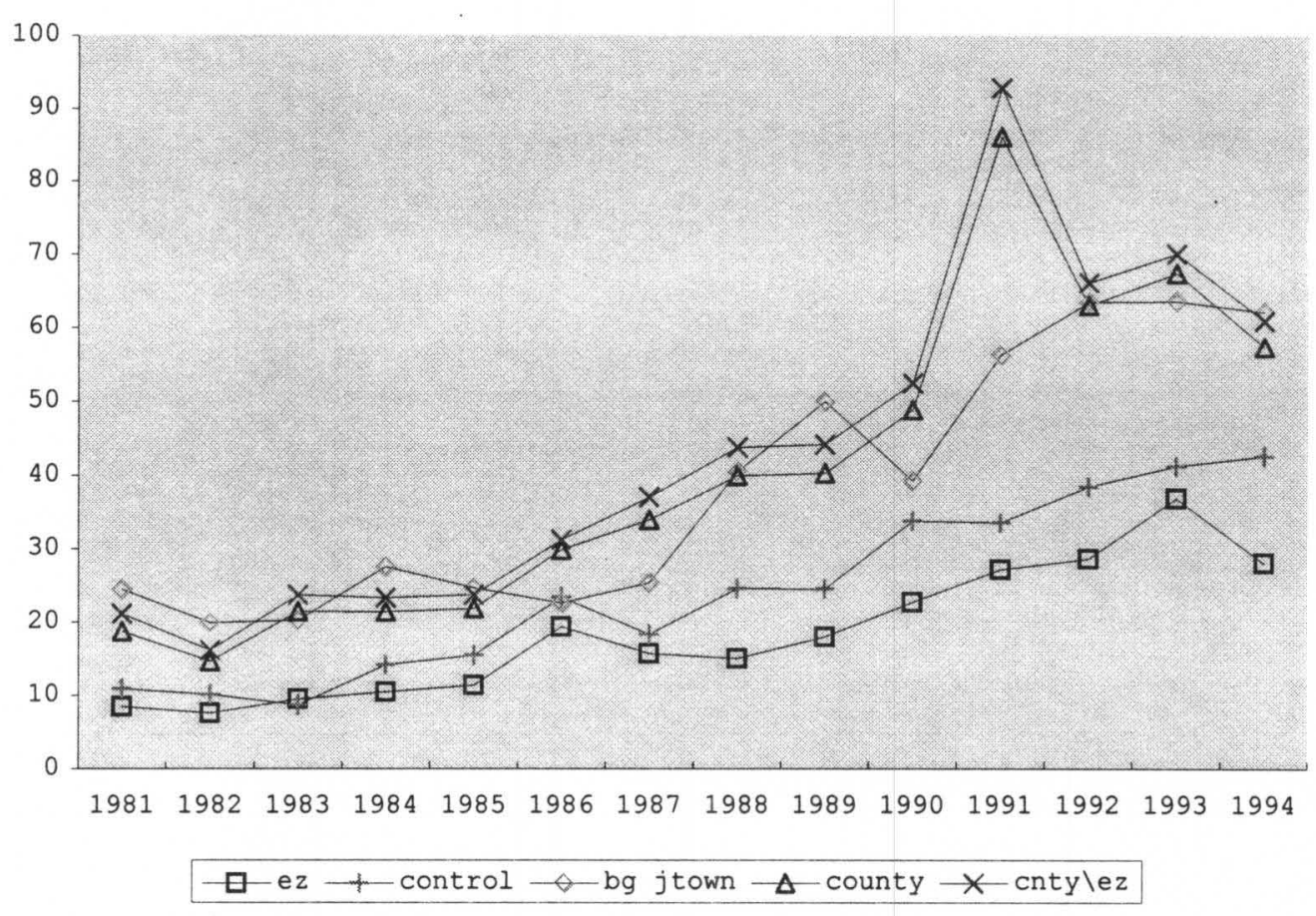

\section{Figure 5}

Figure 5 shows that from 1981 to 1994, all the EZ communities taken together (ez), or the full-size Ez, were behind the control and comparison areas (Newburg or control; Bluegrass and Jeffersontown or bg jtown; the county; and the county outside of the Ez or cnty\ez) when it came to home mortgage lending as a percentage of total home mortgage loans in millions. The volume of loans for the full-size EZ did increase over this time period, but so did the volume for all the comparison areas. This last point is underscored by Figure 6 where it is revealed that even though lending rates did accelerate for the full-size EZ (ez) during this time, the growth rates of mortgage lending for the comparison areas were 
somewhat larger.

Growth Rates of Mortgage Lending

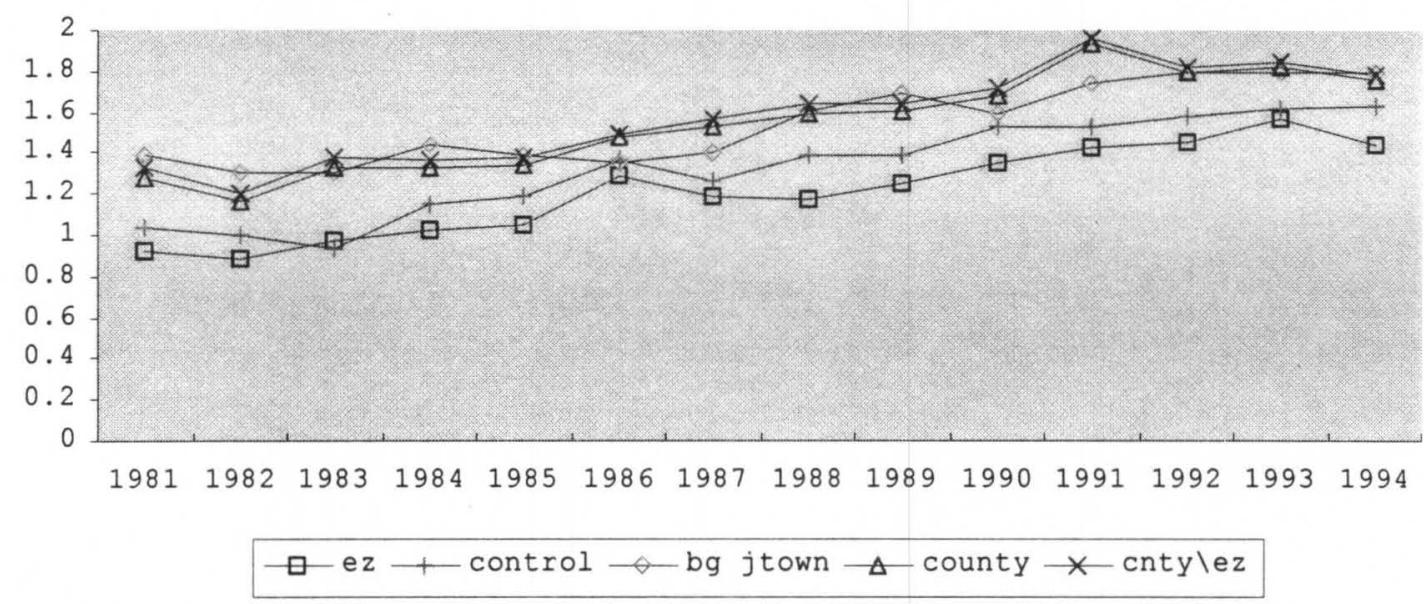

\section{Figure 6}

Next, Figure 7 shows that when comparing the average loan amount within the $\mathrm{EZ}$, the ratio of average home mortgage loan values in the full-size or current EZ to average home mortgage loan values in the comparison areas falls below 1.0 for most of the years between 1981 and 1994. The exception to this is 1983 when the average loan in the EZ exceed the average value of a loan in the Newburg area (cg). Other than that, the current EZ (established in 1986) saw less home mortgage dollars on average than did the county outside of the EZ (ez/balcnty) as well as the county as a whole (ez/all cnty). Only with the Newburg area does the full-size Ez come close to matching average home loan values. 
RATIO OF AVG. LOAN IN CURRENT EZ TO AVG. LOAN AMOUNT IN OTHER AREAS

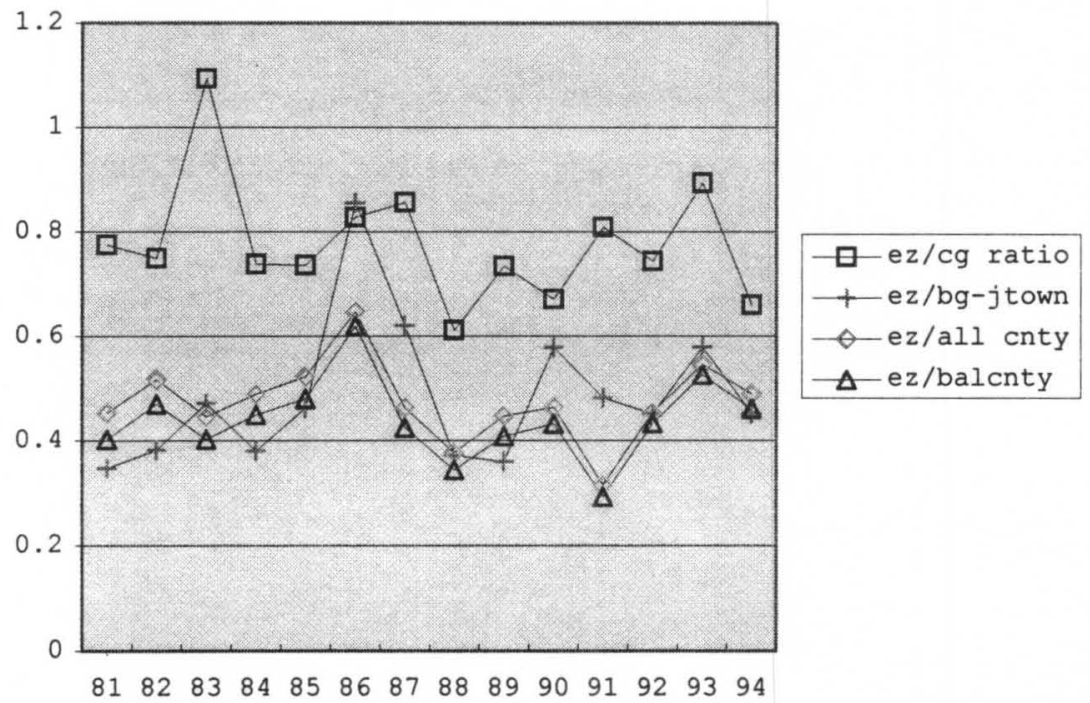

Figure 7

Just as with the Census data, these results do not show the Ez catching up with or surpassing the control (Newburg) or comparison communities when it comes to rates of housing investment or value of investment. The three figures show that lending patterns generally varied to the same degree in the $\mathrm{EZ}$ as it did in the comparison communities, but that the amount of investment in the EZ never came close to what was being invested in Newburg, other parts of Jefferson County, or the county as a whole.

The Census data showed the Ez communities to be behind the comparison communities in regard to housing stock value, housing occupancy and new housing units. Any improvement in 
this situation would have required a dramatic amount of investment in new housing or housing rehabilitation during the 1980 s and early 1990s. The rate of investment would probably have had to be much greater than what these three charts show. Such a low housing investment rate raises the question of whether the neighborhood improvement component of the EZ legislation was ever taken seriously by state and local economic development officials.

\section{Evaluating Neighborhood Revitalization using County Property Valuation Administration Records}

Information obtained from Jefferson County's PVA office allowed calculating increases or decreases in tax assessment values of homes in the $\mathrm{EZ}$ areas and the control areas (Newburg, Jefferson County outside of the EZ, and Jefferson County as a whole). Tax assessment values are not the same as the fair market values of housing used in the Census data. However, if one assumes a high correlation between assessment values and fair market values for housing in general in any given neighborhood, then any increases or decreases in assessment values from one point in time to another may indicate a rise or fall in the fair market values of housing for a particular area.

The local PVA office was able to provide computerized assessment data for the years 1992 through 1996. There are no computerized records before 1992. However, a look at changes in assessment values from 1992 to 1996 would provide the 
opportunity to examine assessment, and indirectly, home value appreciation in the $\mathrm{EZ}$ and control areas beyond the 1980 and 1990 Census data. The previous section showed that this type of revitalization was apparently not significant between 1980 and 1990. Perhaps there are lagged effects with regard to EZ incentives that could not have shown neighborhood revitalization taking place by 1990 .

Before going further, it should be noted that PVA records are not kept according to either zip code or census tract. Instead, the local PVA office has its own geographic configuration of neighborhoods in order to do its job of regularly re-assessing and taxing property values. These neighborhoods are not necessarily defined in the same sense as one may conceive of neighborhoods in general. How residents see their neighborhood may be different from how the PVA defines their neighborhood. Because the PVA is interested in administering and collecting taxes in a cost efficient and effective manner, PVA neighborhoods are mostly clusters of very similar housing within a geographic area.

The average of the assessments for each PVA neighborhood for the five years 1992 to 1996 was averaged. PVA neighborhoods were combined to closely mirror those areas in the $\mathrm{EZ}$ and the control areas and to take the average of the average of the assessments for each assigned neighborhood. Using averages is somewhat flawed because of the risk of a skewed distribution of assessment values within a particular neighborhood. However, median assessment values were not 
available.

PVA records indicate that for the neighborhoods taken in by the original EZ, the average of the mean values of PVA neighborhood housing assessments in that area rose from $\$ 16,787$ in 1992 to $\$ 18,793$ in 1996 . This was an increase of 11.9 응

In those neighborhoods taken in by the first EZ expansion and added to the original EZ neighborhoods (which together constituted Figure 2, the Intermediate Enterprise Zone), the average of the mean values of PVA assessments rose from roughly $\$ 32,727$ in 1992 to $\$ 41,246$ in 1996 for an increase of 26.03\%. Meanwhile, in those neighborhoods taken in by the second EZ expansion in 1986, the average of the mean values of assessments rose from approximately $\$ 32,239$ in 1992 to $\$ 39,892$ in 1996 for an increase of $23.74 \%$. Finally, for the total or full-size EZ, the average of the neighborhood means rose from $\$ 30,437$ in 1992 to $\$ 37,550$ in 1996 for a 23.37용 increase in average values. Clearly, the EZ areas outside of the original EZ as well as the full-size EZ saw a much greater increase over the five year period in homeowner's wealth if one assumes a correlation between assessment values and fair market values.

For the Newburg area, Jefferson County outside of the EZ, and for Jefferson County as a whole, average neighborhood home assessment values also rose between 1992 and 1996 . In Newburg, the average assessment rose from $\$ 38,439$ in 1992 to $\$ 50,667$ in 1996. This was an increase of $31.8 \%$ and was the 
largest increase for all areas examined. The area of the county outside of the EZ saw the average of mean values of assessments rise from $\$ 62,944$ in 1992 to $\$ 75,543$ in 1996 for a 20.02\% increase. During the same time period, PVA records indicate that all of Jefferson County saw the average of the means of home assessment values for all PVA neighborhoods rise from $\$ 60,156$ to $\$ 70,767$. This was a $17.64 \%$ increase in average assessment values.

What does one conclude from this analysis? First, if assessment values are adequately correlated with fair market values, the poorest part of the EZ, the original EZ, saw homeowner's wealth increase the least. This is in stark contrast to one of the poorest areas of the county outside of the EZ, the Newburg area. This area saw the largest average increase in its residential wealth, yet received none of the economic development stimulus or incentives provided by EZ legislation. The Newburg area received no comparable economic development assistance during this time period. Perhaps new subdivisions were started in this area during this time period. This may explain such a large rise in average assessments. However, even this explanation underscores the problems of the original EZ: a lack of new housing development large enough to offset housing stock losses; outward migration; and high unemployment (see Tables 2, 4, and 5). If $E Z$ incentives are working in the original zone area, then they are having a minimal impact at best. In fairness to the EZ area, the full-size EZ as well as 
those areas in the EZ outside of the original zone, did slightly outperform Jefferson County and Jefferson County outside of the $\mathrm{EZ}$ when it came to increases in average assessment values. This could be due to a renewal of housing development in the southwestern part of Jefferson County (Stahl, 1997). During the 1970s and 1980s, southern and southwestern Jefferson County saw little if any new housing communities develop. Most new development during this time period took place in southeastern and eastern Jefferson County, although these areas continue to see robust residential housing development (Stahl, 1997).

However, one cannot say whether $\mathrm{EZ}$ incentives played a key role, if any role, in the increase in new housing development throughout most of the full-size EZ. Based upon three February 19, 1997 Courier Journal articles by Linda Stahl, the 1990s have seen a housing boom throughout all of Jefferson County. The fastest growing area was the $40299 \mathrm{zip}$ code (which includes Jeffersontown and a large part of southeastern Jefferson County), but data based upon new home permits issued from 1992 to 1996 showed that almost every zip code in the county saw an increase in permits taken out for new home construction that was greater than the rate of permits issued in the 1980s (P A1 and CJ Neighborhoods section, p. 1).

The reasons given for the housing boom included a revival in the demand for lower middle income and middle income housing as well as the opening of a major highway, the 
Gene Snyder Freeway. The Snyder was credited with opening up mostly rural-like undeveloped land throughout the outlying areas of Jefferson County. Since a housing boom has been taking place throughout most of Jefferson County throughout the 1990s, it is difficult to make the argument that EZ incentives played a role in higher average assessment values from 1992 to 1996 in the EZ area outside of the original zone. In fact, trends in the full-size Ez seem to be merely reflecting county-wide trends.

\section{Summary}

Based upon the preceding analysis and discussion, it seems that EZ incentives did very little if anything to encourage neighborhood revitalization within targeted areas. The first goal of KRS 154.45 was to improve the quality of life of EZ residents through job training programs and neighborhood redevelopment programs. With the exception of the original EZ area, neighborhood growth and development within the EZ did not generally differ that much from the rest of the county outside of the Ez or Jefferson County as a whole. Improving EZ neighborhoods apparently vanished as a goal as the EZ program became a general economic development tool and lost its focus on alleviating urban problems. 


\section{CHAPTER VI \\ Louisville EZ Performance Evaluation: \\ Job Creation and Retention}

\section{Overview}

Two broad goals of KRS 154.45 (Subchapter 45: Enterprise Zone Development) were to "Improve the quality of life of individuals that reside within an enterprise zone by providing employment opportunities,..." and to "Encourage economic activity by assisting and maintaining existing business within an enterprise zone." (Kentucky Revised Statutes, p. 412).9 These goals were obviously aimed at job creation and retention, usually the most important goals of most if not all enterprise zones (Green, 1991). Whether new jobs were created and/or retained by $\mathrm{EZ}$ incentives, and whether the number of new jobs created and/or retained by $\mathrm{EZ}$ incentives were significant are the issues to be addressed in this part of the evaluation.

According to the Louisville and Jefferson County office for Economic Development (OED), the Louisville EZ is responsible for creating approximately 18,000 new jobs between its inception in 1983 and June 30, 1996. ${ }^{10}$ As noted

9 See the appendix for the full text of KRS 154.45, Subchapter 45: Enterprise Zone Development.

10 The figure 18,000 is from a quote by OED spokesperson Bill Pettison in an August 14, 1996 Courier-Journal article (Sheldon Shafer, p. El). However, if OED annual figures of jobs created are summed, then the number of new jobs created by the EZ from 1983 to June 30,1996 is 19,664. OED attributes this discrepancy to changes made in record-keeping in 1992 .

$$
\text { A survey of EZ certified firms done by the University of }
$$


previously, the accuracy of OED numbers has been called into question. This chapter will attempt to check the accuracy and plausibility of these numbers using shift-share analysis and survey results.

First, an example is necessary to illustrate one of the methods--shift-share analysis--used to evaluate job creation. Tables 7 through 9 (see next several pages) compare Jefferson County's economic growth and changes in its industrial structure to national economic growth and changes in national industrial structure from 1981 to 1994. These tables are the results of a shift-share analysis, a technique used in urban and regional economics to see how much of a region's growth

Louisville's Urban Studies Institute projected a different amount for jobs created--5,760. However, respondents also credited the EZ incentives with saving 3,152 jobs and creating or saving 6,333 jobs. Without regard to incentives, the 851 companies surveyed (out of the approximately 1,200 certified firms) indicated that their workforce had grown by a net of 13,271 employees since the companies had acquired EZ certification. However, not all 851 companies had been certified at the time that the zone had come into existence. Some companies had been certified since 1983 whereas others had only been certified for a couple of years.

Unfortunately, United Parcel Service (UPS) was not interviewed. According. to a phone conversation in October 1996 that I had with Ken Shapero of UPS's Public Relations Office, in 1981 UPS employed 900 workers. As noted earlier in this paper, UPS became part of the EZ in 1986. Ten years later, Shapero reported that UPS employed around 14,000 people, $80 \%$ of whom are part-time workers. Adding 14,000 to the 13,271 jobs that respondents reported would greatly boost the number of jobs created within the $\mathrm{EZ}$ without regard to incentives.

Since there does not appear to be any firm estimate of the number of jobs created due to $\mathrm{EZ}$ incentives, this paper will use OED's figure of 18,000 new jobs created between 1983 and 1996. This gives OED the benefit of the doubt when it comes to establishing a hard number on the jobs created within the EZ from 1983 to 1996. Also, these are the only official numbers that exist. 
Table 7

SHIFT-SHARE ANALYSIS

Jefferson County and United States Economy

Years 1981 to 1994

TPU

other

TOTAL

Employment

1981

1994

\section{Nation}

Agricultural services, etc.

Mining

Contract Construction

Manufacturing

TPU

Wholesale Trade

Retail Trade

F/I/RE

Services

other

TOTAL
Jefferson County

Agricultural services, etc.

Mining

Contract Construction

Manufacturing

Wholesale Trade

Retail Trade

E/I/RE

Services

$\begin{array}{rr}302694 & 586069 \\ 1107726 & 607721 \\ 4286069 & 4709379 \\ 20428330 & 18098123 \\ 4613030 & 5713515 \\ 5260928 & 6365973 \\ 15039998 & 20320266 \\ 5409780 & 7002431 \\ 17814081 & 33253032 \\ 5887766 & 76791 \\ \mathbf{7 4 8 5 0 4 0 2} & 96733300\end{array}$

Employment

1981

1994

1210

1508

479

252

15428

18803

88922

65021

16677

27183

22771

27838

56494

74706

20100

26002

67842

122811

1775

183

291698

364307

Change, 1981-94

Absolute

Percent

$\begin{array}{rr}283375 & 93.62 \\ -500005 & -45.14 \\ 423310 & 9.88 \\ -2330207 & -11.41 \\ 1100485 & 23.86 \\ 1105045 & 21.00 \\ 5280268 & 35.11 \\ 1592651 & 29.44 \\ 15438951 & 86.67 \\ -510975 & -86.94 \\ 21882898 & 29.24\end{array}$

Change 1981-94

Absolute

Percent

$\begin{array}{rr}298 & 24.63 \\ -227 & -47.39 \\ 3375 & 21.88 \\ -23901 & -26.88 \\ 10506 & 63.00 \\ 5067 & 22.25 \\ 18212 & 32.24 \\ 5902 & 29.36 \\ 54969 & 81.03 \\ -1592 & -89.69 \\ 72609 & 24.89\end{array}$

Source: 1981 and $1994 \mathrm{KY}$

and U.S. County Business

Patterns. 
National Growth Effect, Jefferson Co. 1981-94

Industry Employment

\begin{tabular}{|c|c|c|c|c|}
\hline & 1981 & $\star \mathbf{N}$ & $\mathbf{R}$ & $\begin{array}{l}\star R-N \\
=M+S\end{array}$ \\
\hline Agricultural services, etc. & 1210 & 354 & 298 & -56 \\
\hline Mining & 479 & 140 & -227 & -367 \\
\hline Contract Construction & 15428 & 4511 & 3375 & -1136 \\
\hline Manufacturing & 88922 & 26001 & -23901 & -49902 \\
\hline TPU & 16677 & 4876 & 10506 & 5630 \\
\hline Wholesale Trade & 22771 & 6658 & 5067 & -1591 \\
\hline Retail Trade & 56494 & 16519 & 18212 & 1693 \\
\hline $\mathrm{F} / \mathrm{I} / \mathrm{RE}$ & 20100 & 5877 & 5902 & 25 \\
\hline Services & 67842 & 19837 & 54969 & 35132 \\
\hline Other & 1775 & 519 & -1592 & -2111 \\
\hline TOTAL & 291698 & 85292 & 72609 & -12683 \\
\hline
\end{tabular}

$\star_{N}=1981$ County Employment X Nat'l Grovth Rate of 29.248

$\star R-N=M+S$ is the Net Relative Change to be explained by shift-share.

Industry Mix Effect, Jefferson County 1981-94

Industry

breakdown:
Nation

Agricultural services, etc.

Mining

Contract Construction

Manufacturing

TPU

Wholesale Trade

Retail Trade

F/I / RE

Services

other

TOTAL

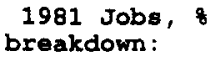

0.40

1.48

5.73

27.29

6.16

7.03

20.09

7.23

23.80

0.79

100.00

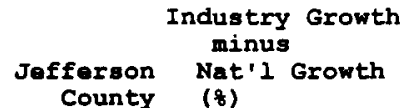

county

0.41

64.38

$0.16 \quad-74.38$

$5.29-19.36$

$30.48 \quad-40.65$

$5.72 \quad-5.38$

$7.81-8.24$

$19.37 \quad 5.87$

$6.89 \quad 0.20$

$23.26 \quad 57.43$

$0.61-116.18$

100.00
Emp. $1981 \quad$ \M

$1210 \quad 779$

$479-356$

$15428 \quad-2987$

$88921-36143$

$16667-897$

$22771-1875$

$56494 \quad 3315$

$20100 \quad 40$

$67842 \quad 38960$

$1775-2062$

$291687-1228$

$\star M=$ Product of previous two columns.

is due to national and industry-specific trends as opposed to 
possible local trends, local initiatives and local competitive advantages. If a region generates more jobs than what national economic and industry-specific (or, industry-mix) growth rates would indicate, then that region could be said to possibly have a competitive advantage within certain industrial sectors (if not all sectors) relative to the rest of the nation (Hoover and Giarratani, 1984, pp. 398-401; and Bendavid-Val, 1991, pp. 67-72). All the data come from the

Table 9

Employment and Components of Employment Change, Jefferson Co., 1981-94

\begin{tabular}{|c|c|c|c|c|c|c|}
\hline & 1981 & 1994 & R N & & $\mathbf{M}$ & $\star \mathbf{S}$ \\
\hline \multicolumn{7}{|l|}{ Industry } \\
\hline Agricultural services, etc. & 1210 & 1764 & 298 & 354 & 779 & -835 \\
\hline Mining & 479 & 254 & -227 & 140 & -356 & -11 \\
\hline Contract Construction & 15428 & 16742 & 3375 & 4511 & -2987 & 1851 \\
\hline Manufacturing & 88922 & 62608 & -23901 & 26001 & -36143 & -13759 \\
\hline TPU & 16677 & 26375 & 10506 & 4876 & -897 & 6527 \\
\hline Wholesale Trade & 22771 & 27147 & 5067 & 6658 & -1875 & 284 \\
\hline Retail Trade & 56494 & 71715 & 18212 & 16519 & 3315 & -1622 \\
\hline$F / I / R E$ & 20100 & 26288 & 5902 & 5877 & 40 & -15 \\
\hline Services & 67842 & 119417 & 54969 & 19837 & 38960 & -3828 \\
\hline Other & 1775 & 102 & -1592 & 519 & -2062 & -49 \\
\hline TOTAL & 291698 & 352412 & 72609 & 85292 & -1228 & -11455 \\
\hline
\end{tabular}

1981 and 1994 U. S. and Kentucky County Business Patterns (U.S. Department of Commerce, 1981 and 1994). Table 7 shows that national employment grew 29.24\% between 1981 to 1994 . However, within major industrial sectors, growth rates varied from a high of $93.62 \%$ in agricultural services, forestry, fisheries, and food processing to a negative growth rate of 
$-45.14 \%$ in mining. All other categories had positive growth rates except for manufacturing $(-11.41 \%)$ and other establishments that were not classified $(-86.94 \%) .{ }^{11}$

Meanwhile, Jefferson County had an overall employment growth rate of $24.89 \%$ during this time period with 72,609 jobs being added to payrolls. Jefferson County job creation closely resembled the nation's when it came to the areas of mining, wholesale trade, retail trade, finance, insurance and real estate (F/I/RE), and services. On the other hand, Jefferson County had over double the growth in the number of jobs created in the area of transportation and public utilities (TPU) than did the nation and had nearly two and a one-half times the number of jobs lost in manufacturing than did the nation $(-26.88 \%$ for Jefferson County versus $-11.41 \%$ for the U. S.). Finally, Jefferson County experienced an increase in jobs in agricultural services, etc. (24.63\%), but this did not come close to national job growth (93.62\%). The top portion of Table 8 shows that if each major industrial sector within Jefferson County grew at the national growth rate of $29.24 \%$ between 1981 and 1994, then the county would have seen 85,292 new jobs generated. This number is designated as " $N$ ", the employment that would have resulted if national trends had been duplicated in the locality during the time period under consideration. The number of jobs that

11 The reason for the dramatic drop in the other category is straightforward. Between 1981 and 1993, the Census Bureau adopted a new Standard Industrial Code (SIC) which created new classifications for businesses. This allowed for establishments previously not classified to be put into a 
existed in 1981 is used as a base for calculating N. " $R$ " is the actual number of jobs created in each sector from 1981 to 1994 (see Table 7). Since this number is 72,609, Jefferson County generated 12,683 fewer jobs than what national trends would have produced (see last column, top half of table 8). This difference of 12,683 is called the "net relative change" that shift-share analysis must explain. In other words, the analysis must explain what industry-specific and local factors prevented Jefferson County from producing jobs at the same rate as the national economy.

The bottom half of Table 8 shows what would be the effects of industry-specific trends and growth rates less or "minus" the overall national growth rate of $29.24 \%$ on local industrial development. In other words, the percentage national growth rates for each industry (see top half of Table 7, last column) less the overall U. S. growth rate of $29.24 \%$ gives the percentages shown in the fourth column of the bottom half of Table 8 . These percentages are then multiplied by the level of employment within each industry in Jefferson County for 1981 to yield " $M$ ", the industry mix effect, that shows the number of jobs that should have been produced had industry-specific growth rates (less the national growth rate) been duplicated in Jefferson County. In total, Jefferson County produced 1,228 fewer jobs than what national industrial trends would have produced had those same trends been duplicated in the county.

major industrial category. 
Finally, Table 9 decomposes the effects of national and industry-specific effects on Jefferson County job growth from 1981 to 1994. "S" is the Local Share Effect or the competitive component of shift-share analysis. The competitive component is possibly the job creation in a region due to any local competitive advantages that may exist in that region which would cause job growth in that region to be higher than what would be expected given national and industry-specific growth trends. The reverse could also be true. If "S" is negative, then the region could have a negative competitive component given national and industryspecific trends.

It should be noted, however, that the reasons why a locality may have a positive or negative competitive component cannot be explained by shift-share analysis (MIT Dictionary of Modern Economics, 1989, p. 386; Blair, 1995, pp. 148-149). This is because $S$ is a residual number. It is the result of subtracting $N$ and $M$ from $R$ (the actual job growth within the locality). As Table 9 shows, when $\mathrm{N}$ and $\mathrm{M}$ are subtracted from R, Jefferson County had a negative competitive component relative to the rest of the nation when it came to job creation from 1981 to 1994. Jefferson County should have produced 11,455 more jobs than it actually did. That is, if national and industry-specific trends had been duplicated in Jefferson County from 1981 to 1994, then an even greater number of jobs would have been created--11,455 more than the 72,609 produced. Despite job gains in agricultural services, 
TPU, construction, wholesale trade and F/I/RE, these gains were not enough to offset losses in other industrial categories, especially in manufacturing, where local conditions are assumed to possibly account for the loss of 13,759 (see column "S") out of the 23,901 actual manufacturing jobs lost (see column "R") between 1981 to 1994. ${ }^{12}$ As Blair (1995, p. 146) writes, "Growth differentials due to the nature of the local environment are termed the competitive component. The mix and competitive components account for regional growth that differs from the national level."

Now that shift-share analysis has been illustrated and explained, the method will now be applied in comparing Ez job growth to job growth in Jefferson County for the periods 1980 to 1990 and from 1981 to 1994. Both the original-size EZ and the current or "full-size" EZ will be compared to Jefferson County job growth. Because the area that comprised the first expansion of the original EZ was so short-lived (a little over one year) and because this area later became part of the larger full-size EZ, an evaluation of this version of the $E Z$

12 These results are interesting because it is during this time period that local governments took on most, if not all, the tasks of economic development because of declining support from the federal government. The results may indicate that creating and then enlarging the EZ, selling economic development bonds and industrial revenue bonds and pursuing other economic development policies (e.g., recruitment of businesses into the local area) may have had little effect on local economic growth. Or, if these economic development policies did have some positive impact, perhaps they were not enough to offset areas where Jefferson County suffered a comparative disadvantage relative to other regions of the country (e.g., inferior schools and universities, an unskilled workforce, etc.). 
will be skipped. The following analysis is similar to that followed by Dowall (1996) in his evaluation of California's Enterprise Zones.

As mentioned earlier, census tracts form the foundation of the Louisville EZ. All tracts must be contiguous and must be in an area that is on average an economically depressed and blighted area. The difficulty in doing a shift-share analysis at a level within the county boundaries lies in the fact that County Business Patterns does not collect firm and employment data at the census tract level. Likewise, the 1980 and 1990 Censuses of Housing and Population do not collect firm and employment data at the tract level. Yet, even though county Business Patterns does not have data at the census tract level, it does have data at the zip code level going back to 1981 (Dowall, 1996). Using a method where zip code areas are matched as closely as possible to areas within the Ez (Dowall, 1996), one could use data from 1981 to 1994 (the most recent data available at the time of the writing of this study) in a shift-share analysis of the EZ. This would provide a 14 year time period for a pre- and post-test analysis with the EZ being in existence for nearly 11 of those 14 years. Also, a recent report prepared for Jefferson County Government estimated the location and number of jobs by census tract for both 1980 and 1990 census boundaries (Coomes and Price, 1994). Using these numbers, a shift-share analysis comparing both versions of the EZ to Jefferson County job creation at the tract level is possible. As the following tables show, both 
data sources indicate the same trends and support each other. Shift-share analysis dictates that a sub-region of a larger area be compared to the larger area (as in comparing Jefferson County to the U. S.) (Bendavid-Val, 1991; Blair, 1995, pp. 145-149). This chapter will compare both EZs (the original and the full-size) to Jefferson County job growth rates over two different time periods. Shift-share analysis would not allow a comparison between either version of the EZ to either the Newburg or Bluegrass Industrial Park areas (the control communities) because all of these areas are subregions of Jefferson County. The county must be used as a point of reference if shift-share analysis is to be done properly. Therefore, the control communities' and the Louisville airport's rate of job growth will be compared to that of Jefferson County's rate in the next chapter. In that way, inferences can be made as to how well the Ez (in its original and current sizes) did in comparison not only to Jefferson county but also in comparison to these other two areas. In this chapter as well as the next, it is assumed that if EZ incentives were working, then one would expect job creation and retention in the $\mathrm{EZ}$ communities and the airport to at least match and/or exceed the rate of job creation and retention in Jefferson County, as well as the Bluegrass and Newburg areas. 


\section{Job Creation in the Original Ez versus the County, 1980 to 1990 and 1981 to 1994}

As noted earlier, the original EZ was 3.75 square miles of commercial and residential property west of Louisville's CBD. The following evaluation of the original EZ's capacity to create jobs covers two parallel time periods because of the use of two different data sources: estimates based on the 1980 and 1990 Censuses of Housing and Population (Coomes and Price) and 1981 and 1994 County Business Patterns data at the zip code level (U. S. Commerce Department, 1981 and 1994). The same two data sources and corresponding time periods will be used throughout the rest of this section of the study while comparing different sub-regions of Jefferson County to the county as a whole.

On the following pages, Tables 10 through 12 compare the original Ez to Jefferson County using data from the 1980 and 1990 Censuses and 1980 and 1990 County Business Patterns (CBP) data for all of Jefferson County. ${ }^{13}$ The top half of Table 10 shows jobs by major industry classification according to the 1980 and 1990 CBPs for the County. Because of the coomes and Price method (1994), some major industry categories have been combined (e.g., Agricultural Services and Mining, TPU and Wholesale Trade, and Services and Government). ${ }^{14}$

13 Aggregate numbers for the county could have derived from the 1980 and 1990 Census data. However, in order to make all tables comparable, the top half of each table will have data from County Business Patterns.

14 Actually, County Business Patterns (CBP) does not disclose the number of jobs in the government sector of our economy. 110 
Between 1980 and 1990, Jefferson County added 37,913 jobs to its jobs base, an increase of $12.78 \%$. Meanwhile, the second part of Table 10 shows that those census tracts that composed the original EZ lost 6,890 jobs between 1980 and 1990, a decrease of $-26.12 \%$. At the end of 1990, EZ incentives would have been in effect for at least six and a half years. Clearly the job losses estimated in the original EZ from 1980 to 1990 do not do much to support the argument that incentives helped to "[I]mprove the quality of life of individuals that reside within an enterprise zone by providing employment opportunities..." or to "[E] ncourage economic activity by stimulating the influx of new business within an enterprise zone..." (KRS 154.45, p. 412 (see appendix)) .

TABLE 10

\section{SHIFT-SHARE ANALYSIS}

Comparison of Original Ez to Jefferson County, 1980-1990

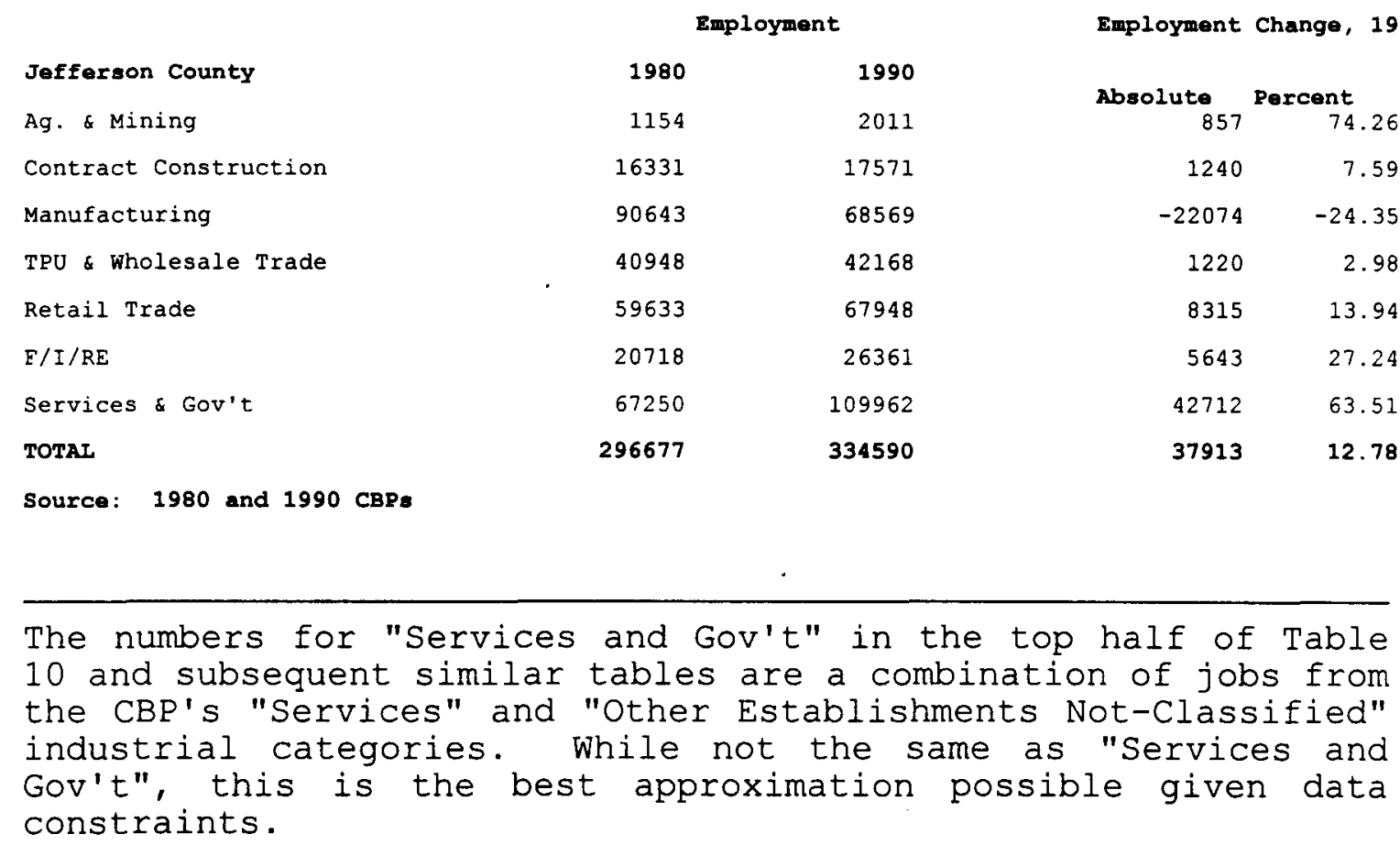


TABLE 10, CONTINUED.

Original Enterprise Zone Area

Ag. \& Mining

Contract Construction

Manufacturing

TPU \& Wholesale Trade

Retail Trade

$\mathrm{F} / \mathrm{I} / \mathrm{RE}$

Services \& Gov't

TOTAL
Employment

1980

$\begin{array}{rr}136 & 44 \\ 740 & 775 \\ 14846 & 9757 \\ 5853 & 3060 \\ 1454 & 1445 \\ 229 & 396 \\ 3125 & 4016 \\ 26383 & 19493\end{array}$

Employment Change 1980-90

Absolute Percentage

$\begin{array}{rr}-92 & -67.65 \\ 35 & 4.73 \\ -5089 & -34.28 \\ -2793 & -47.72 \\ -9 & -0.62 \\ 167 & 72.93 \\ 891 & 28.51 \\ -6890 & -26.12\end{array}$

Source: 1980 and 1990 Censuses of Housing and Population.

In fact the first part of Table 11, column 3, shows that if job growth in the original $\mathrm{EZ}$ had been the same as the county during this period, the EZ would have gained 3,371 jobs. On the other hand, looking at the last column of the

TABLE 11

Jefferson Co. Growth Effect for original EZ, 1980-90

Industry

Ag. Mining

Contract Construction

Manufacturing

TPU \& Wholesale Trade

Retail Trade

F/I / RE

Services \& Gov't

TOTAI
Employment

1980

136

740

14846

5853

1454

229

3125

26383

\begin{tabular}{|c|c|c|}
\hline $\begin{array}{l}N=\text { Employment } \\
1980 x \\
\text { County Growth } \\
\text { Rate }(12.788)\end{array}$ & $\mathbf{R}$ & $\begin{array}{r}\mathbf{R}-\mathrm{N} \\
=\mathrm{M}+\mathrm{S}\end{array}$ \\
\hline 17 & -92 & -109 \\
\hline 95 & 35 & -60 \\
\hline 1897 & -5089 & -6986 \\
\hline 748 & -2793 & -3541 \\
\hline 186 & -9 & -195 \\
\hline 29 & 167 & 138 \\
\hline 399 & 891 & 492 \\
\hline 3371 & -6890 & -10261 \\
\hline
\end{tabular}


TABLE 11, CONT'D

Industry Mix Effect, Enterprise Zone, 1980-90

Distribution of Total

1980 Employment (z)

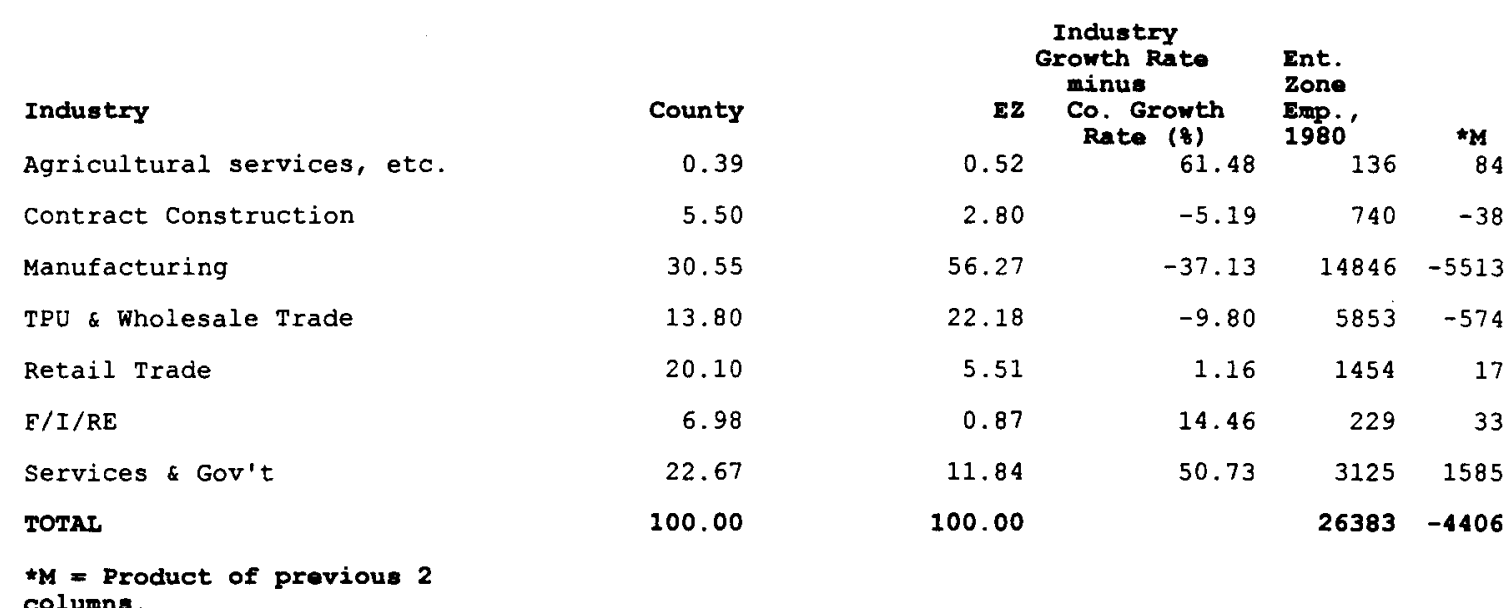

TABLE 12

Employment and Components of Employment Change, Enterprise Zone, 1980-90

Industry

Ag. \& Mining

1980

1990

R N M S

Contract Construction

136

740

Manufacturing

14846

TPU \& Wholesale Trade

5853

Retail Trade

1454

$F / I / R E$

229

Services \& Gov't

3125

TOTAL

26383

$\begin{array}{rrrrr}44 & -92 & 17 & 84 & -193 \\ 775 & 35 & 95 & -38 & -22 \\ 9757 & -5089 & 1897 & -5513 & -1473 \\ 3060 & -2793 & 748 & -574 & -2967 \\ 1445 & -9 & 186 & 17 & -212 \\ 396 & 167 & 29 & 33 & 105 \\ 4016 & 891 & 399 & 1585 & -1093 \\ 19493 & -6890 & 3371 & -4406 & -5855\end{array}$

$S$ is Local Share Effect-arad's competitive component.

$S=R-N-M$

second part of Table 11, the EZ should have lost 4,406 jobs

due to industry-specific trends that existed in the county during this time. On net, the original EZ still should have only lost $1,035(=3,371-4,406)$ jobs. The fact that it lost around six times this number in addition to failing to generate 3,371 jobs is reflected by the $-5,855$ figure in the 
last column of Table $12 .{ }^{15}$ The $-5,855$ is the original Ez's competitive component relative to the rest of Jefferson County. Of the 6,890 jobs lost in this area between 1980 and $1990,5,855$ of these jobs were lost possibly due to some attribute(s) that the EZ had that the rest of Jefferson County did not have or had to a lesser degree (e.g., higher crime rates, a high number of unskilled workers, etc.). Another reason why this area may have been especially hard hit is that when one looks at column 3 of the bottom half of Table 11 one notices that the original EZ had almost twice the percentage of its workforce in manufacturing than did the rest of the county in 1980. Deindustrialization not only hit Jefferson County hard in general, but may have hit certain areas within the county harder than others.

Tables 13 through 15 compare the original EZ to Jefferson County using zip code level data from the U. S. Commerce Department's 1981 and 1994 County Business Patterns (CBP). According to Dowall (1996, p. 365), since 1981 the Census Bureau has been keeping zip code level CBP data for the entire U. S. The data for firms are presented according to zip code within each county at the four-digit SIC level. That is, for a given zip code, the total number of firms in a fourdigit SIC classification is noted along with a breakdown of how many firms in that classification fall into different size categories (e.g., 1 to 4 employees, 5 to 9 employees, 10 to 19 employees, etc., up to those firms with 1000 or more

$\overline{15-5855=-6890-3371}--4406, \underset{114}{\text { or } S=R-N-M .}$ 
employees). The data files do not show how many people are employed within each 4-digit SIC category within each zip, but this number can be estimated by using state-wide or countywide level data.

For the purposes of this study, Dowall's methodology for evaluating the 13 California EZs was adapted by aggregating "the establishment tabulations to the 2-digit level from the 4-digit level of aggregation (4-digit is based on a more

\section{TABLE 13}

\section{SHIFT-SHARE ANALYSIS}

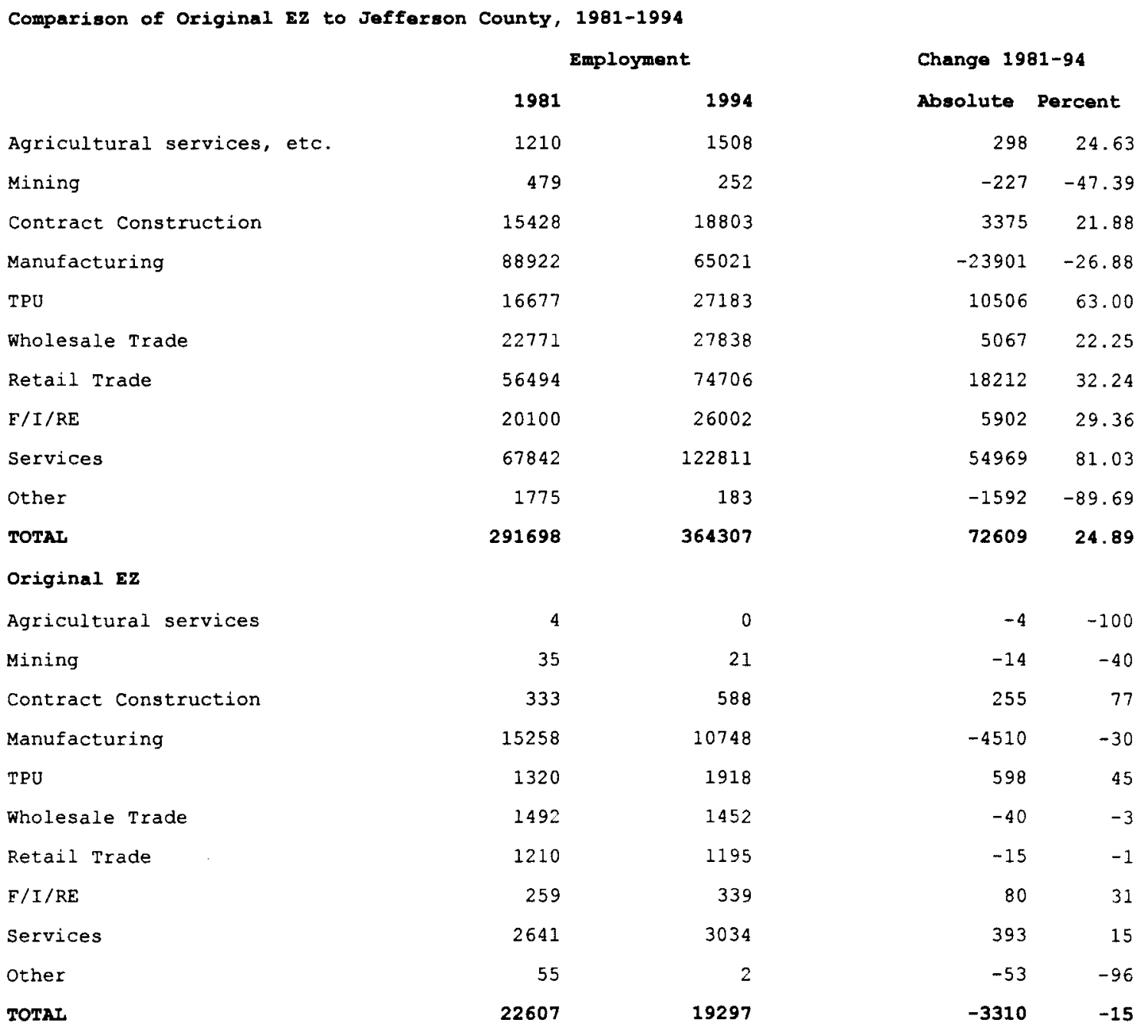

Source: 1981 and $1994 \mathrm{CBPs}$. 
specific breakdown of economic activity than 2-digit)" and by estimating "average employment for each establishment size category by 2-digit SIC category." (p. 365). The estimation of average employment for each establishment size category in this study was done by using County Business Patterns total number of firms and employment state-wide by 2-digit SIC and TABLE 14

County Growth Effect, Original Ez, 1981-94

$\begin{array}{lr}\text { Industry } & \text { Employment, } \\ \text { Agricultural services, etc. } & 3 \\ \text { Mining } & 33 \\ \text { Contract Construction } & 1525 \\ \text { Manufacturing } & 132 \\ \text { TPU } & 149 \\ \text { Wholesale Trade } & 121 \\ \text { Retail Trade } & 259 \\ \text { F/I/RE } & 264 \\ \text { Services } & 55 \\ \text { Other } & 22607 \\ \text { TOTAL } & \end{array}$

1981
35
333
15258
1320
1492
1210
259
2641
55
22607

\begin{tabular}{rrr}
$* \mathbf{N}$ & \multicolumn{1}{c}{$\mathbf{R}$} & $\mathbf{R}-\mathbf{N}=\mathbf{M}+\mathbf{S}$ \\
1 & -4 & -5 \\
9 & -14 & -23 \\
83 & 255 & 172 \\
3798 & -4510 & -8308 \\
329 & 598 & 269 \\
371 & -40 & -411 \\
301 & -15 & -316 \\
64 & 80 & 16 \\
657 & 393 & -264 \\
14 & -53 & -67 \\
$\mathbf{5 6 2 7}$ & $-\mathbf{3 3 1 0}$ & $-\mathbf{8 9 3 7}$
\end{tabular}

${ }_{N} \mathrm{~N}=1981$ Original Ez employment $X$ county growth rate of 24.898 .

$\star_{R}-N=M+S$ : Net relative change to be explained by shift-share analysis.

Industry Mix Effect, Original Ez 1981-1994

\begin{tabular}{|c|c|c|c|c|c|}
\hline \multirow[t]{2}{*}{ Industry } & \multirow[b]{2}{*}{ County } & \multicolumn{2}{|r|}{$\begin{array}{l}\text { Industry } \\
\text { minus } \\
\text { County } \\
\text { Growth }\end{array}$} & \multirow[b]{2}{*}{ EZ Emp. } & \multirow[b]{2}{*}{$\mathbf{M}$} \\
\hline & & $\mathbf{E z}$ & (z) & & \\
\hline Agricultural services, etc. & 0.41 & 0.02 & -0.26 & 4 & 0 \\
\hline Mining & 0.16 & 0.15 & -72.28 & 35 & -25 \\
\hline Contract Construction & 5.29 & 1.47 & -3.01 & 333 & -10 \\
\hline Manufacturing & 30.48 & 67.49 & -51.77 & 15258 & -7899 \\
\hline TPU & 5.72 & 5.84 & 38.11 & 1320 & 503 \\
\hline Wholesale Trade & 7.81 & 6.60 & -2.64 & 1492 & -39 \\
\hline Retail Trade & 19.37 & 5.35 & 7.35 & 1210 & 89 \\
\hline$E / I / R E$ & 6.89 & 1.15 & 4.47 & 259 & 12 \\
\hline Services & 23.26 & 11.68 & 56.14 & 2641 & 1483 \\
\hline Other & 0.61 & 0.24 & -114.58 & 55 & -63 \\
\hline TOTAL & 100 & 100.00 & & 22607 & -5951 \\
\hline
\end{tabular}


by size of firm (Tables $1 b$ and $1 \mathrm{c}$ of Kentucky CBPs).

These estimates of average firm employment using statewide data are then applied to the number of firms identified with each 2-digit SIC and firm size within each zip code within Jefferson County.

Following Dowall (pp. 365-366), I used the estimates of average employment for each firm size category to calculate the average employment for all size of establishment categories for each 2-digit level SIC industry within Jefferson County. Then, similar to Dowall, I estimated employment by size category for each 2-digit SIC category for each zip code within Jefferson County. The estimates were determined by multiplying the average employment estimate of a specific size and 2-digit SIC category by the number of firms in those categories for all 2 digit SIC categories, for all firm sizes and for all zip codes. When total number of jobs for each zip code was summed, the estimates were only off by 1,636 jobs for 1981 and 2,014 jobs for 1994 when compared to CBP totals for Jefferson County for those years.

Tables 13, 14, and 15 pretty much reinforce and parallel the findings of the shift-share analysis of the 1980 and 1990 Census data. Just as with the 1980 to 1990 time period, the original $\mathrm{EZ}^{16}$ experienced negative growth between 1981 and $1994(-15 \%)$ whereas the county experienced a growth rate of

16 The original EZ census tracts closely correspond to the western half of the area covered by the County's 40203 zip code and all of the 40210 zip code. There have been no changes in zip boundaries within Jefferson County over the fourteen year 
24.89․ The original EZ, therefore, did not generate a net gain of jobs over this time frame and did not meet two of the objectives of KRS 154.45--job and business creation and retention.

TABLE 13

Employment and Components of Employment Change, Original EZ 1981-1994

\begin{tabular}{|c|c|c|c|c|c|c|}
\hline & 1981 & 1994 & $\mathbf{R}$ & $\mathbf{N}$ & $\mathbf{M}$ & $s *$ \\
\hline \multicolumn{7}{|l|}{ Industry } \\
\hline Agricultural services, etc. & 4 & 0 & -4 & 1 & 0 & -5 \\
\hline Mining & 35 & 21 & -14 & 9 & -25 & 3 \\
\hline Contract Construction & 333 & 588 & 255 & 83 & -10 & 182 \\
\hline Manufacturing & 15258 & 10748 & -4510 & 3798 & -7899 & -409 \\
\hline TPU & 1320 & 1918 & 598 & 329 & 503 & -234 \\
\hline Wholesale Trade & 1492 & 1452 & -40 & 371 & -39 & -372 \\
\hline Retail Trade & 1210 & 1195 & -15 & 301 & 89 & -405 \\
\hline $\mathrm{F} / \mathrm{I} / \mathrm{RE}$ & 259 & 339 & 80 & 64 & 12 & 4 \\
\hline Services & 2641 & 3034 & 393 & 657 & 1483 & -1747 \\
\hline Other & 55 & 2 & -53 & 14 & -63 & -4 \\
\hline TOTAL & 22607 & 19297 & -3310 & 5627 & -5951 & -2986 \\
\hline
\end{tabular}

Table 14 shows that had the county's growth trend been achieved in the original EZ, 5, 627 jobs would have been created (see top half, third column, "N"). On the other hand, given industry-specific trends, the EZ should have lost 5,951 jobs (see bottom half, last column, "M"). The net effect would have been a job loss of 324 , yet this area actually lost 3,310 jobs. Table 15, Column "S" implies that this difference period 1981-1994. 
of $2,986(=3310-324)$ is possibly due to some competitive disadvantage(s) that the original EZ had relative to the county. As with the Census data, one can assume the same possible causes of such a disadvantage.

\section{Job Creation in the Full-size Ez versus the County, 1980 to 1990 and 1981 to 1994}

The next few pages compare the current 45.7 square-mile EZ, "Full-size EZ", to Jefferson County job creation using the 1980 and 1990 Census data as well as 1980 and 1990 CBP data. Table 16 shows that the full-size $\mathrm{EZ}^{17}$ suffered a small decline in job numbers--1,126 jobs lost, or a $1.09 \%$ drop. Table 17 indicates that had the full-size EZ grown at the county's growth rate, the EZ should have generated 13,226 jobs. Since the industry mix effect shows that the full-size EZ should have lost 3,387 jobs (see last column, bottom of table) the full-size EZ, according,to shift-share analysis, should have generated a net of 9,839 jobs. But since the EZ failed to generate this number of jobs, and instead lost 1,126 jobs, the EZ has a negative competitive component relative to the county. In fact, Column "S" of Table 18 shows that the full-size EZ had a competitive component of 10,965 jobs that "should" have been retained or created. Again, shift-share analysis cannot pinpoint "causality" or explain why the full-

17 This is composed of those census tracts in the original Ez as well as those census tracts added in 1986. 
size EZ suffered from a negative competitive component. One can speculate that perhaps this area suffered from high crime, poor infrastructure, deindustrialization, etc., although maybe not to the same degree as the original Ez.

\section{TABLE 16}

\section{SHIFT-SHARE ANALYSIS}

Comparison of Full-size Ez to Jefferson County, 1980-1990

Jefferson County
Ag. \& Mining
Contract Construction
Manufacturing
TPU \& Wholesale Trade
RetaiI Trade
F/I/RE
Services \& Gov't
TOTAI

TOTAL

Source: 1980 and $1990 \mathrm{CBPs}$

Full-size Ez
Ag. \& Mining
Contract Construction
Manufacturing
TPU \& Wholesale Trade
Retail Trade
F/I/RE
Services \& Gov't

TOTAL

Source: 1980 and 1990 Censuses.
Employment

1980 1990

$\begin{array}{rr}1154 & 2011 \\ 16331 & 17571 \\ 90643 & 68569 \\ 40948 & 42168 \\ 59633 & 67948 \\ 20718 & 26361 \\ 67250 & 109962 \\ 296677 & 334590\end{array}$

Employment 1980 1990

613

5180

40546

17885

11731

2184

25352

103491

687
5722
33155
17783
13331
2759
28928
102365

Change, 1980-90

Absolute Percent

$\begin{array}{rr}857 & 74.26 \\ 1240 & 7.59 \\ -22074 & -24.35 \\ 1220 & 2.98 \\ 8315 & 13.94 \\ 5643 & 27.24 \\ 42712 & 63.51 \\ 37913 & 12.78\end{array}$

Change 1980-90

Absolute Percent

$\begin{array}{rr}74 & 12.07 \\ 542 & 10.46 \\ -7391 & -18.23 \\ -102 & -0.57 \\ 1600 & 13.64 \\ 575 & 26.33 \\ 3576 & 14.11 \\ -1126 & -1.09\end{array}$


TABLE 17

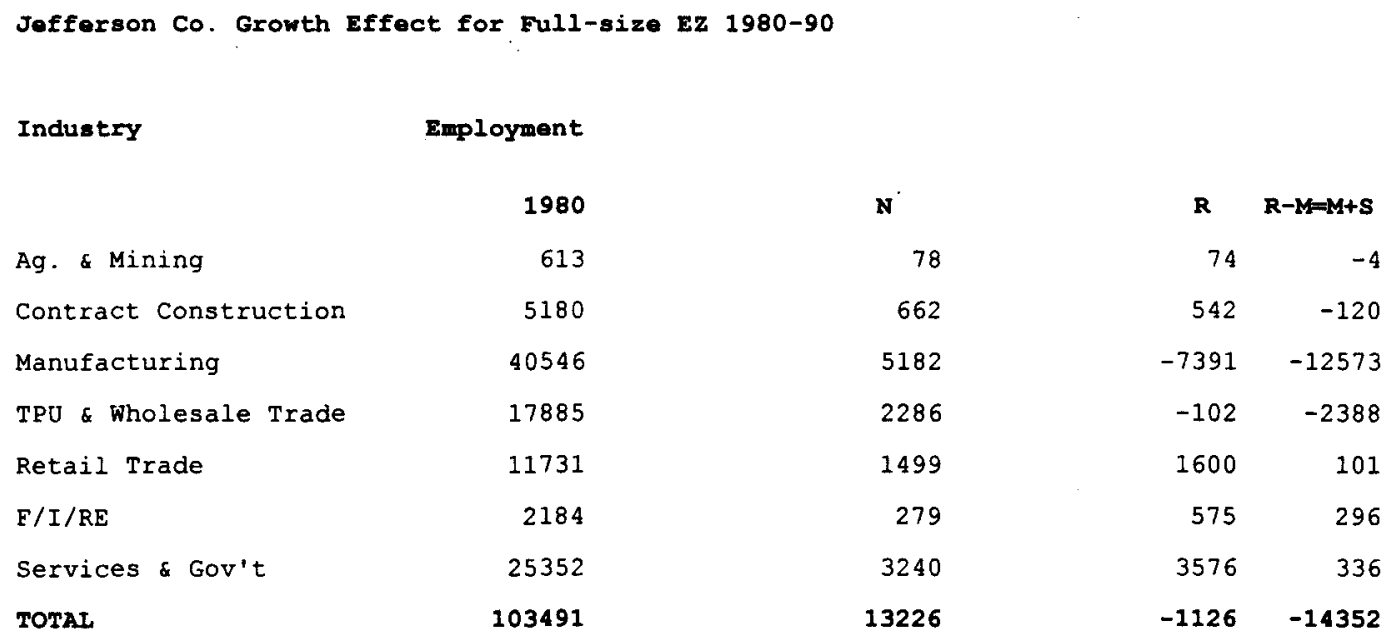

Industry Mix Effect, Full-size Enterprise zone, 1980-90

Distribution of Total

1980 Employment (8)

Industry

Agricultural services,
etc.
Contract Construction
Manufacturing
TPU \& Wholesale Trade
Retail Trade
E/I/RE
Services \& Gov't

TOTAL

Source: 1980 and 1990

\begin{tabular}{|c|c|c|c|c|}
\hline County & $E \mathbf{Z}$ & $\begin{array}{l}\text { Industry Growth } \\
\text { Rate } \\
\text { minus } \\
\text { County Growth } \\
\text { Rate (z) }\end{array}$ & $\begin{array}{l}\text { Ez } \\
\text { Emp. },\end{array}$ & $M$ \\
\hline 0.39 & 0.59 & 61.48 & 613 & 377 \\
\hline 5.50 & 5.01 & -5.19 & 5180 & -269 \\
\hline 30.55 & 39.18 & -37.13 & 40546 & -15056 \\
\hline 13.80 & 17.28 & -9.80 & 17885 & -1753 \\
\hline 20.10 & 11.34 & 1.16 & 11731 & 137 \\
\hline 6.98 & 2.11 & 14.46 & 2184 & 316 \\
\hline 22.67 & 24.50 & 50.73 & 25352 & 12862 \\
\hline 100.00 & 100.00 & & 103491 & -3387 \\
\hline
\end{tabular}


TABLE 18

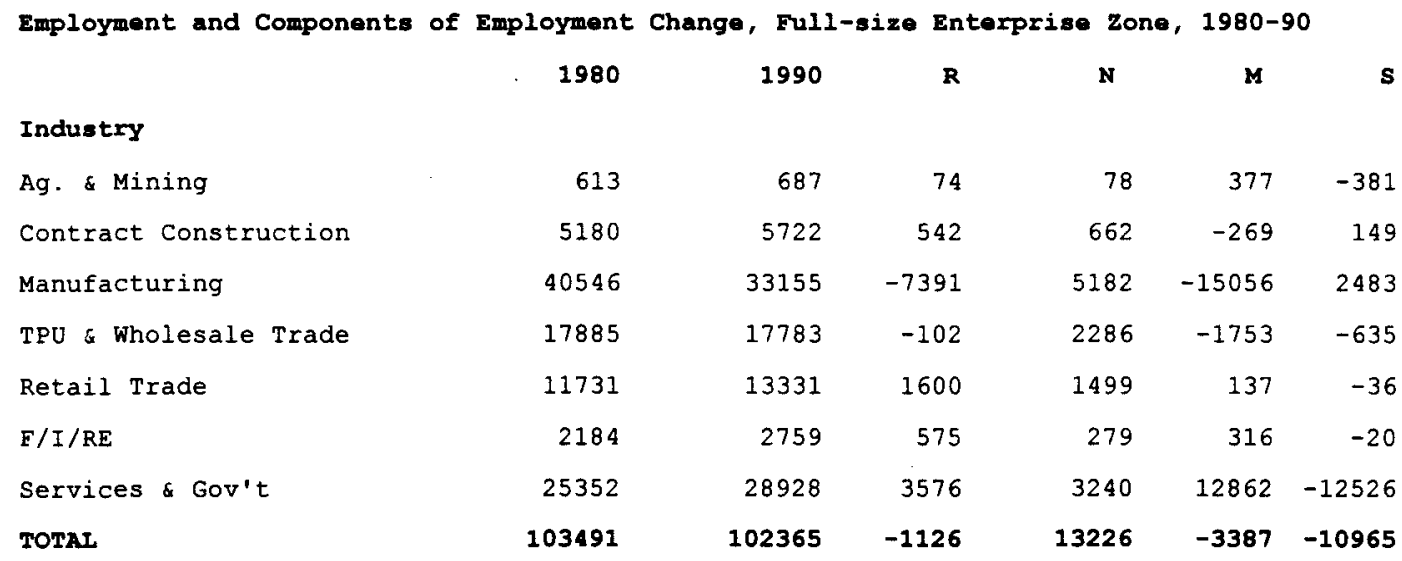

S is Local Share Effect-area's competitive component.

$S=R-N-M$

The same two areas are compared in Tables 19 through 21 using 1981 and 1994 CBP zip code data. ${ }^{18}$ Table 19 indicates that at best the full-size EZ experienced minor economic growth over the fourteen year period $(+3.46 \%)$. Given the previous analysis of these two areas, one can reasonably conclude that economic growth in the full-size Ez during the

18 Job figures for the full-size EZ were estimated by using the Dowall method. Specifically, job estimates for Jefferson County zip codes that fell entirely within EZ boundaries were not truncated, whereas zip codes that partially overlapped EZ boundaries were truncated by one-half or by whatever amount seemed reasonable given comparisons between zip code and census tract maps of the county. This is a crude but necessary adjustment as acknowledged by Dowall (p. 366) because it assumes that all businesses are equally spaced throughout a geographic area.

Specifically, for the purposes of shift share analysis, the full-size Ez took in all of the 40210, 40209, 40219,40221 (Louisville International Airport) and 40292 (University of Louisville) zip codes. It also took in one-half of zip codes 40203, 40204, 40211, 40212, 40213, 40214, 40216, 40217, and 40258. Finally, one-fourth of zip 40272 was included since a portion of Riverport Industrial Park is in this zip code. 
TABLE 19

SHIFT-SHARE ANAYYSIS

Comparison of Full-size Ez to Jefferson County, 1981-1994

Jefferson County
Agricultural services, etc
Mining
Contract Construction
Manufacturing
TPu
Wholesale Trade
Retail Trade
F/I/RE
Services
Other
TOTaL

1981

1994

1210

479

15428

88922

16677

22771

56494

20100

67842

1775

291698

Full-size Ez

Agricultural services

Mining

Contract Construction

Manufacturing

TPU

Wholesale Trade

Retail Trade

$F / I / R E$

Services

other

TOTAL

Source: 1981 and $1994 \mathrm{CBPs}$
Change 1981-94

Absolute Percent

$\begin{array}{rr}298 & 24.63 \\ -227 & -47.39 \\ 3375 & 21.88 \\ -23901 & -26.88 \\ 10506 & 63.00 \\ 5067 & 22.25 \\ 18212 & 32.24 \\ 5902 & 29.36 \\ 54969 & 81.03 \\ -1592 & -89.69 \\ 72609 & 24.89\end{array}$

$\begin{array}{ll}-35 & -12.50\end{array}$

$-74 \quad-77.89$

$3 \quad 0.06$

$\begin{array}{ll}-13455 & -34.27\end{array}$

$2925 \quad 52.41$

$307 \quad 4.48$

$5942 \quad 41.29$

$92 \quad 2.88$

$7724 \quad 53.55$

$\begin{array}{ll}-339 & -91.37\end{array}$

$3090 \quad 3.46$

1980 s and early 1990 s was pretty much non-existent or stagnant despite EZ incentives being introduced in 1983 and then expanded in 1986. Looking at the top half, third column of Table 20, the full-size EZ should have created 22,245 jobs had it grown at the same rate as the county (24.89\%). At the same 
time, the EZ should have lost 9,726 jobs due to the

TABLE 20

County Growth Effect, Full-size EZ, 1981-94

Industry

Employment

1981

Agricultural services, etc.

Mining

Contract Construction

Manufacturing

TPU

Wholesale Trade

Retail Trade

E/I/RE

Services

Other

TOTAL
280

95

4909

39265

5581

6858

14390

3199

14424

371

89372
$\mathbf{N}$

$\mathbf{R}$

$\begin{array}{rrr}70 & -35 & -105 \\ 24 & -74 & -98 \\ 1222 & 3 & -1219 \\ 9773 & -13455 & -23228 \\ 1389 & 2925 & 1536 \\ 1707 & 307 & -1400 \\ 3582 & 5942 & 2360 \\ 796 & 92 & -704 \\ 3590 & 7724 & 4134 \\ 92 & -339 & -431 \\ 22245 & 3090 & -19155\end{array}$

Industry Mix Effect, Full-size EZ 1981-1994

Distribution of Total

1981 Employment $(q)$

Industry

Agricultural services, etc.

Mining

Contract Construction

Manufacturing

TPU

Wholesale Trade

Retail Trade

$F / I / R E$

services

other

TOTAL

\begin{tabular}{rrr} 
County & \multicolumn{2}{c}{$\begin{array}{c}\text { Industry Growth } \\
\text { Rate minus } \\
\text { County Growth Rate } \\
(8)\end{array}$} \\
0.41 & 0.31 & -0.26 \\
0.16 & 0.11 & -72.28 \\
5.29 & 5.49 & -3.01 \\
30.48 & 43.93 & -51.77 \\
5.72 & 6.24 & 38.11 \\
7.81 & 7.67 & -2.64 \\
19.37 & 16.10 & 7.35 \\
6.89 & 3.58 & 4.47 \\
23.26 & 16.14 & 56.14 \\
0.61 & 0.42 & -114.58 \\
100 & 100.00 &
\end{tabular}

$\begin{array}{rr}\text { Emp. } & M \\ 1981^{\prime} & -1 \\ 280 & -69 \\ 95 & -148 \\ 4909 & -20327 \\ 39265 & -2127 \\ 5581 & 2181 \\ 6858 & -181 \\ 14390 & 1057 \\ 3199 & 143 \\ 14424 & 8097 \\ 371 & -425 \\ 89372 & -9726\end{array}$

Source: 1981 and 1994 CBPs.

industry mix effect (bottom half, last column of Table 20). Therefore, the EZ should have seen the creation of at least a net of 12,519 jobs given county and industry mix trends. 
Employment and Components of Employment Change, Full-size EZ 1981-1994

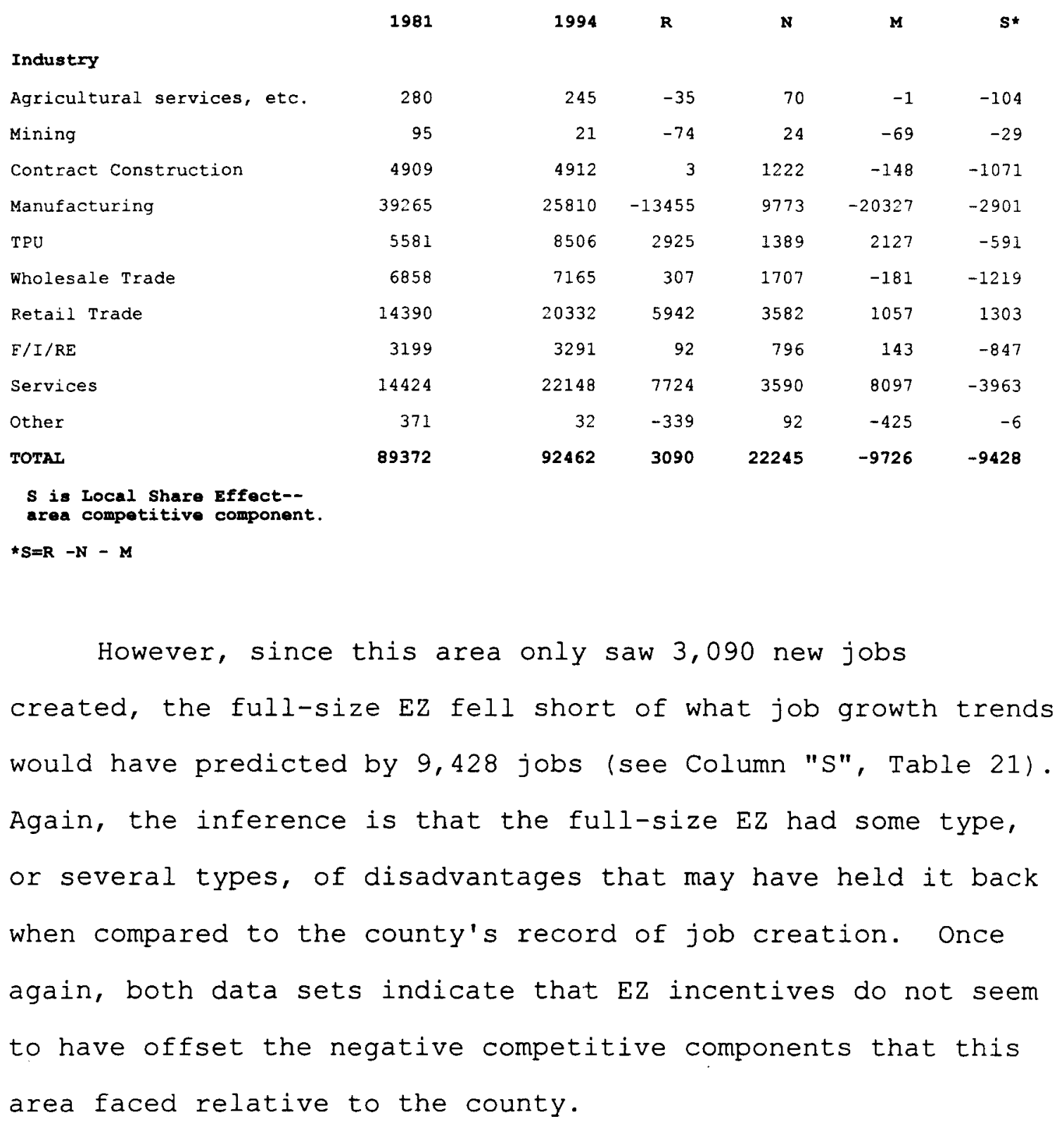

\section{Job Creation in the Airport area versus the County, 1980 to 1990 and 1981 to 1994}

In order to control for any stimulus that $E Z$ incentives had on the growth of Louisville's airport that may have caused 125 
it to grow faster than the rest of the full-size EZ, the following tables were created.

TABLE 22

SHIFT-SHARE ANALYSIS

Comparison of Louisville Airport Area to Jefferson County, 1980-1990

\begin{tabular}{rrrr}
\multicolumn{2}{c}{ Employment } & \multicolumn{3}{c}{$\begin{array}{c}\text { Employment Change, } \\
\text { 1980-90 } \\
\text { Absolute }\end{array}$} & Percent \\
1980 & 1990 & & \\
1154 & 2011 & 857 & 74.26 \\
16331 & 17571 & 1240 & 7.59 \\
90643 & 68569 & -22074 & -24.35 \\
40948 & 42168 & 1220 & 2.98 \\
59633 & 67948 & 8315 & 13.94 \\
20718 & 26361 & 5643 & 27.24 \\
67250 & 109962 & 42712 & 63.51 \\
296677 & 334590 & 37913 & 12.78
\end{tabular}

Source: 1980 and $1990 \mathrm{CBPs}$

\begin{tabular}{|c|c|c|}
\hline \multicolumn{2}{|c|}{ Employment } & \multirow{2}{*}{$\begin{array}{l}\text { Change } \\
1980-90 \\
\text { Absolute }\end{array}$} \\
\hline 1980 & 1990 & \\
\hline
\end{tabular}

Louisville Airport Araa

Ag. \& Mining
Contract Construction
Manufacturing
TPU \& Wholesale Trade
Retail Trade
F/I/RE
Services \& Gov't

TOTAL

Source: 1980 and 1990 Censuses.

$\begin{array}{rrrr}126 & 218 & 92 & 73.02 \\ 1230 & 1507 & 277 & 22.52 \\ 4775 & 3688 & -1087 & -22.76 \\ 3440 & 7293 & 3853 & 112.01 \\ 1479 & 2604 & 1125 & 76.06 \\ 221 & 516 & 295 & 133.48 \\ 2558 & 4395 & 1837 & 71.81 \\ 13829 & 20221 & 6392 & 46.22\end{array}$

Because the airport is somewhat like an industrial park, it was believed that $\mathrm{EZ}$ incentives may have had a greater effect on this area than on other EZ areas. The Census data in Table 22 show the airport growing at a much faster rate than the rest of Jefferson County. This is due in large part to jobs created in TPU and wholesale trade. There were also 
large percentage increases in Ag. and Mining, F/I/RE and Services and Gov't, but nearly half of the new jobs created were in TPU and Wholesale Trade.

\section{TABLE 23}

\begin{tabular}{|c|c|c|c|c|}
\hline Industry & Employment & $\mathbf{N}$ & $\mathbf{R}$ & $R-N=M+S$ \\
\hline & 1980 & & & \\
\hline Ag. \& Mining & 126 & 16 & 92 & 76 \\
\hline Contract Construction & 1230 & 157 & 277 & 120 \\
\hline Manufacturing & 4775 & 610 & -1087 & -1697 \\
\hline TPU \& Wholesale Trade & 3440 & 440 & 3853 & 3413 \\
\hline Retail Trade & 1479 & 189 & 1125 & 936 \\
\hline$E / I / R E$ & 221 & 28 & 295 & 267 \\
\hline Services \& Gov't & 2558 & 327 & 1837 & 1510 \\
\hline TOTAL & 13829 & 1767 & 6392 & 4625 \\
\hline
\end{tabular}

Industry Mix Effect, Louisville Airport Area, 1980-90

Distribution of Total

1980 Employment (z)

Industry

Agricultural services, etc.

Contract Construction

Manufacturing

TPU \& Wholesale Trade

Retail Trade

F/I/RE

Services \& Gov't

TOTAL

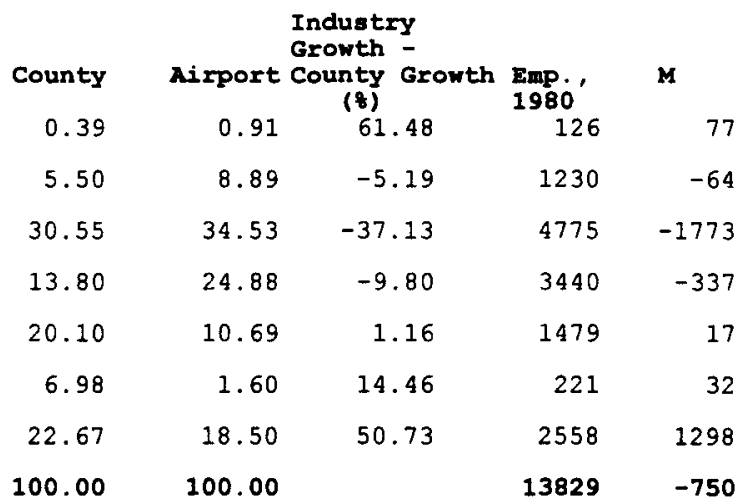

Table 23 shows that the airport created jobs across all industries (with the exception of manufacturing) at a rate greater than the county whereas industry trends show that the airport fell short of generating 750 jobs that should have been created ("M") . 
Finally, Table 24 (next page) shows that the airport had a positive competitive component relative to the county in that 4,486 jobs were created due to the fact that airport job growth rates outperformed the overall county average despite not outperforming industry growth rates. However, it should be pointed out that during this time period of 1980 to 1990, the airport underwent massive reconstruction and expansion. Millions of dollars from the Federal Aviation Administration (FAA) and bonds sold by the Commonwealth of Kentucky financed the construction of a second runway for the airport. This second runway allowed United Parcel Service (UPS) to expand its operations from a nearly 1,000 employees in 1981 to nearly 14,000 by 1994. Therefore, EZ incentives cannot be given full credit for this expansion in jobs at Louisville International Airport.

Finally, the Coomes and Price database, which used 1980 and 1990 Census data, defined the Louisville airport as covering four 1990 census tracts: tracts 55, 91.01, 92, and 119.01. This area is actually slightly larger than the area encompassed by the airport itself and so this may cause the airport job numbers to be slightly larger than if one used the airport's exact boundaries. Perhaps Coomes and Price should have labeled this as the "airport area." 


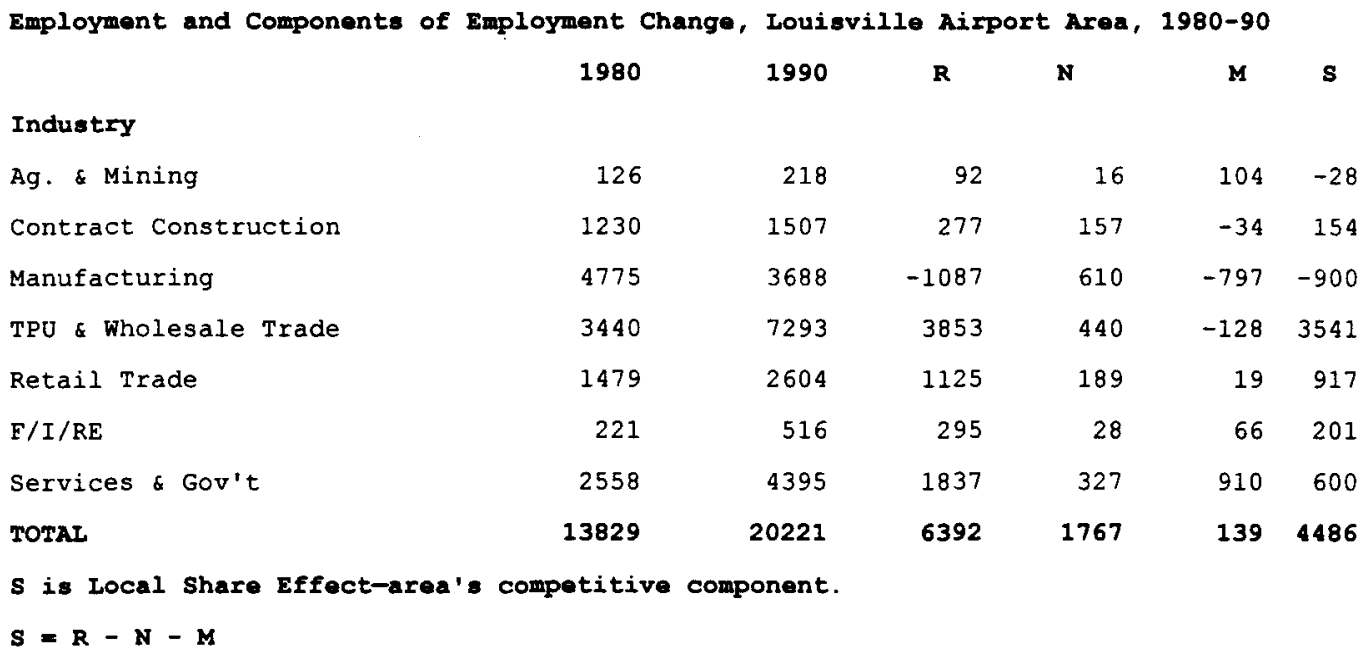

Table 25 uses CBP data at the zip code level to look at job growth in the airport. For zip code purposes, Louisville International Airport has been classified as zip code 40221 for at least the last 16 years (Louisville Branch, U. S. Post Office). The zip code boundary more closely reflects the airport boundaries than the four census tracts used by Coomes and Price. Because of a smaller geographic area covered, Table 25 shows no employment in some major industry categories. This is to be expected because as one goes from a larger area to a smaller area, one expects to find fewer firms. Table 25 shows job growth at a rate better than the other areas examined under the $\mathrm{EZ}$, but this growth rate is still not as good as that of the county's as a whole. 
TABLE 25

SHIFT-SHARE ANALYSIS

Comparison of Louisville Airport to Jefferson County using CBP zip Code Data

\begin{tabular}{|c|c|c|c|c|}
\hline & & & Change 198 & $1-94$ \\
\hline & 1981 & 1994 & Absolute & Percent \\
\hline Jefferson County & & & & \\
\hline Agricultural services, etc. & 1210 & 1508 & 298 & 24.63 \\
\hline Mining & 479 & 252 & -227 & -47.39 \\
\hline Contract Construction & 15428 & 18803 & 3375 & 21.88 \\
\hline Manufacturing & 88922 & 65021 & -23901 & -26.88 \\
\hline TPU & 16677 & 27183 & 10506 & 63.00 \\
\hline Wholesale Trade & 22771 & 27838 & 5067 & 22.25 \\
\hline Retail Trade & 56494 & 74706 & 18212 & 32.24 \\
\hline $\mathrm{E} / \mathrm{I} / \mathrm{RE}$ & 20100 & 26002 & 5902 & 29.36 \\
\hline Services & 67842 & 122811 & 54969 & 81.03 \\
\hline Other & 1775 & 183 & -1592 & -89.69 \\
\hline TOTAL & 291698 & 364307 & 72609 & 24.89 \\
\hline
\end{tabular}

\section{Airport-Entire 40221 zip Code}

Agricultural services, etc.

Mining

Contract Construction

Manufacturing

TPU

Wholesale Trade

Retail Trade

$\mathrm{F} / \mathrm{I} / \mathrm{RE}$

Services

Other

TOTAL

23869

4

0

0

5311

3022

1235

7337

5816

1021

123
Change, 1981-94

Absolute Percent

$\begin{array}{rr}-4 & -100.00 \\ 0 & 0.00 \\ 0 & 0.00 \\ -5056 & -95.20 \\ 15943 & 527.56 \\ 4991 & 404.13 \\ -5258 & -71.66 \\ -4806 & -82.63 \\ -780 & -76.40 \\ -109 & -88.62 \\ 4921 & 20.62\end{array}$

Source: 1981 and 1994 CBPs.

In fact, Table 26 shows the airport should have generated 5,941 jobs if it had grown at the county growth rate, yet it fell short by 1,020 jobs. Despite very strong growth in TPU and wholesale trade, this area lost quite a few manufacturing, retail, F/I/RE, and service jobs. I can only 
County Growth Effect, Louisville Airport, 1981-94

\begin{tabular}{lrrrr} 
Industry & Emp. , & N & \multicolumn{2}{r}{ R-N=M+S } \\
Agricultural services, etc. & 4 & 1 & -4 & -5 \\
Mining & 0 & 0 & 0 & 0 \\
Contract Construction & 0 & 0 & 0 & 0 \\
Manufacturing & 5311 & 1322 & -5056 & -6378 \\
TPJ & 3022 & 752 & 15943 & 15191 \\
Wholesale Trade & 1235 & 307 & 4991 & 4684 \\
Retail Trade & 7337 & 1826 & -5258 & -7084 \\
F/I/RE & 5816 & 1448 & -4806 & -6254 \\
Services & 1021 & 254 & -780 & -1034 \\
Other & 123 & 31 & -109 & -140 \\
TOTAI & $\mathbf{2 3 8 6 9}$ & $\mathbf{5 9 4 1}$ & $\mathbf{4 9 2 1}$ & $\mathbf{- 1 0 2 0}$
\end{tabular}

Industry Mix Effect, Airport

\begin{tabular}{|c|c|c|c|c|c|}
\hline Industry & $\begin{array}{c}\text { Distribution of Total } \\
1981 \text { Employment ( } 8) \\
\text { County }\end{array}$ & Airport & $\begin{array}{l}\text { Industry } \\
\text { - Co. } \\
\text { Growth }\end{array}$ & $\begin{array}{l}\text { Emp. } \\
1981\end{array}$ & $M$ \\
\hline Agricultural services, etc. & 0.41 & 0.02 & -0.26 & 4 & 0 \\
\hline Mining & 0.16 & 0.00 & -72.28 & 0 & 0 \\
\hline Contract Construction & 5.29 & 0.00 & -3.01 & 0 & 0 \\
\hline Manufacturing & 30.48 & 22.25 & -51.77 & 5311 & -2750 \\
\hline TPU & 5.72 & 12.66 & 38.11 & 3022 & 1152 \\
\hline Wholesale Trade & 7.81 & 5.17 & -2.64 & 1235 & -33 \\
\hline Retail Trade & 19.37 & 30.74 & 7.35 & 7337 & 539 \\
\hline $\mathrm{F} / \mathrm{I} / \mathrm{RE}$ & 6.89 & 24.37 & 4.47 & 5816 & 260 \\
\hline Services & 23.26 & 4.28 & 56.14 & 1021 & 573 \\
\hline other & 0.61 & 0.52 & -114.6 & 123 & -141 \\
\hline TOTAL & 100 & 100 & & 23869 & -399 \\
\hline
\end{tabular}

specùlate that airport expansion may have caused many firms in these categories to leave the area. Table 26 also shows that the airport came up short as far as industry mix effects. Because employment growth in the airport did not reflect industry growth trends, the column $M$ indicates that the airport did not see 399 jobs created due to industry trends. 
Finally, Table 27 implies that the airport had a small negative competitive component relative to the county. Overall, job generation, if county and industry growth trends had been replicated in the 40221 zip code, 621 more jobs should have been generated between 1981 and 1994 than was actually created.

TABLE 27

\begin{tabular}{|c|c|c|c|c|c|c|}
\hline Industry & 1981 & 1994 & $\mathbf{R}$ & $\mathbf{N}$ & $\mathbf{M}$ & $\mathbf{S}^{*}$ \\
\hline Agricultural services, etc. & 4 & 0 & -4 & 1 & 0 & -5 \\
\hline Mining & 0 & 0 & 0 & 0 & 0 & 0 \\
\hline Contract Construction & 0 & 0 & 0 & 0 & 0 & 0 \\
\hline Manufacturing & 5311 & 255 & -5056 & 1322 & -2750 & -3628 \\
\hline TPU & 3022 & 18965 & 15943 & 752 & 1152 & 14039 \\
\hline Wholesale Trade & 1235 & 6226 & 4991 & 307 & -33 & 4717 \\
\hline Retail Trade & 7337 & 2079 & -5258 & 1826 & 539 & -7623 \\
\hline$F / I / R E$ & 5816 & 1010 & -4806 & 1448 & 260 & -6514 \\
\hline Services & 1021 & 241 & -780 & 254 & 573 & -1607 \\
\hline Other & 123 & 14 & -109 & 31 & -141 & 1 \\
\hline TOTAL & 23869 & 28790 & 4921 & 5941 & -399 & -621 \\
\hline
\end{tabular}

$\star \mathbf{S}=\mathbf{R}-\mathbf{N}-\mathbf{M}$

s is "local share effect" showing an area's competitive component.

It should be noted, however, that job growth in this area was very uneven. Probably because of UPS, growth in TPU and wholesale trade almost offset job losses in other industries. Also, if firms dislocated due to airport expansion stayed in an area close to the airport or within the EZ, then outcomes from the analysis of airport CBP data may be underestimating job growth in this area. 


\section{Summary}

Overall, it does not appear on the surface that EZ incentives did a great deal to stimulate job growth in the targeted areas (with the possible exception of the airport area). One objection that could be raised against this speculation is that if it had not been for the $\mathrm{EZ}$ incentives, then job losses in the EZ (whether in the original EZ or the full-size EZ) would have been even worse. There is, of course, no direct way to refute this possible outcome. In fact, OED claims that EZ incentives helped to create 18,000 new jobs between 1983 and 1996. It has never said whether these 18,000 jobs were "net" of jobs lost. However, OED cannot say that these were net jobs gained because the data herein show this to be impossible. However, the results above do not appear consistent with OED's claim that the EZ is a "\$1 Billion Success Story" (OED Press Release, 1990).

Also, if it can be shown that other areas in Jefferson County similar to the $\mathrm{EZ}$ had attained job growth rates greater than the EZ during the same time period, and if these areas had done so without any type of government intervention, assistance and/or incentives, then the OED claim about success would be further questioned. Consistent with the logic of quasi-experimentation, such comparisons would be in order. The next chapter examines these issues in more detail. 


\section{Job Creation in Control and Comparison Communities}

\section{Job Creation in the Newburg Area versus Jefferson County, 1980 to 1990 and 1981 to 1994}

As mentioned in Chapter 4 and in the previous chapter, it is important to and consistent with the logic of quasiexperimentation to compare changes in the full-size Ez and its component parts to other areas in Jefferson County and to Jefferson County as a whole. Since these other areas did not receive the economic development stimulus of $\mathrm{EZ}$ incentives, it is important to establish whether other areas comparable to the EZ areas changed similarly over time when compared to the EZ.

For that reason, the Newburg area was chosen as a control area to be compared to the $\mathrm{EZ}$ because of its socioeconomic and demographic similarities to the original Ez. Using 1980 and 1990 Census data again, Table 28 shows that the Newburg area saw mild job loss between 1980 and 1990 (a decline of just .31\%). This, of course, is far behind the county's overall growth rate of $12.78 \%$. But it is better than what the census data show for both the original and full-size Ez during the same time period. ${ }^{19}$ If job growth in the Newburg area had

19 Recall that census tracts that comprised the Newburg Area were included as a control area to be compared to EZ areas because of the socioeconomic profile of the area and because 134 
been the same as the county's from 1980 to 1990, then Newburg should have gained 4,367 jobs (Table 29, column 3, top half). At the same time, the industry mix effect shows that because of the Newburg area's industrial composition in 1980, it should have lost 5,609 jobs (Table 29, last column, bottom half). This is probably due to the high concentration of manufacturing jobs within Newburg in 1980: 57.71\% of Newburg's workforce was in manufacturing whereas the county had $30.55 \%$ in manufacturing (Table 29, bottom half, columns 2 and 3 ).

Table 30 shows that because Newburg lost only 106 jobs when it should have lost a net of $1,242(=4,367-5,609)$ jobs, the area had a positive competitive component of $1,136 \quad(=1,242$ - 106) jobs. Newburg was able to "cut its losses" by experiencing job growth in all of the other industrial sectors outside of manufacturing. In this way, the Newburg area was at least able to remain static rather than decline like both versions of the EZ. More importantly, it was able to do so without any economic development stimulus like EZ incentives.

the Newburg area received none of the economic development stimulus or treatment that either the original or full-size EZ received. 
SHIFT-SHARE ANALYSIS

Comparison of Newburg Area to Jefferson County, 1980-1990

Jefferson County

Employment

Change 1980-90

Absolute Percent

Industry

\section{0}

1154

Ag. \& Mining

Contract Construction

16331

90643

40948

59633

20718

67250

296677

1990

TPO \& Wholesale Trade

Retail Trade

F/I/RE

Services \& Gov't

TOTAL

Source: 1980 and $1990 \mathrm{CBPs}$

$1980 \quad 1990$

Newburg Area

Ag. \& Mining

Contract Construction

105

1355

203

Manufacturing

TPU \& Wholesale Trade

Retail Trade

19718

1570

4261

14346

3820

5203

4982

$F / I / R E$

Services \& Gov't

1098

1200

3810

6557

TOTAX

34167

34061

Source: 1980 and 1990 Censuses.

\section{Absolute Percent}

$\begin{array}{rr}857 & 74.26 \\ 1240 & 7.59 \\ -22074 & -24.35 \\ 1220 & 2.98 \\ 8315 & 13.94 \\ 5643 & 27.24 \\ 42712 & 63.51 \\ 37913 & 12.78\end{array}$

Change 1980-90

Absolute Percent

$\begin{array}{rr}98 & 93.33 \\ 215 & 15.87 \\ -5372 & -27.24 \\ 942 & 22.11 \\ 1162 & 30.42 \\ 102 & 9.29 \\ 2747 & 72.10 \\ -106 & -0.31\end{array}$

TABLE 29

Jefferson Co. Growth Effect for Newburg Area, 1980-90

\begin{tabular}{|c|c|c|c|c|}
\hline Industry & $\begin{array}{r}\text { Employment } \\
1980\end{array}$ & $\begin{array}{l}N=\text { Employment } 1980 \times \\
\text { County Growth } \\
\text { Rate }(12.78 \%)\end{array}$ & $\mathbf{R}$ & $\mathrm{R}-\mathrm{N}=\mathrm{M}+\mathrm{S}$ \\
\hline Ag. \& Mining & 105 & 13 & 98 & 85 \\
\hline Contract Construction & 1355 & 173 & 215 & 42 \\
\hline Manufacturing & 19718 & 2520 & -5372 & -7892 \\
\hline TPU \& Wholesale Trade & 4261 & 545 & 942 & 397 \\
\hline Retail Trade & 3820 & 488 & 1162 & 674 \\
\hline $\mathrm{F} / \mathrm{I} / \mathrm{RE}$ & 1098 & 140 & 102 & -38 \\
\hline Services \& Gov't & 3810 & 487 & 2747 & 2260 \\
\hline TOTAL & 34167 & 4367 & -106 & -4473 \\
\hline
\end{tabular}


TABLE 29, CONTINUED.

Industry Mix Effect, Newburg Area, 1980-90

Distribution of Total

1980 Employment (8)

Industry

Agricultural services, etc.

Contract construction

Manufacturing

TPU \& Wholesale Trade

Retail Trade

F/I/RE

Services \& Gov't

TOTAL

\begin{tabular}{rrrrr} 
County & \multicolumn{3}{c}{$\begin{array}{c}\text { Industry Growth minus } \\
\text { County Growth }\end{array}$} & $\begin{array}{l}\text { Nowburg } \\
\text { Emp... } \\
1980\end{array}$ \\
0.39 & 0.31 & 61.48 & 105 & $\mathbf{M}$ \\
5.50 & 3.97 & -5.19 & 1355 & -70 \\
30.55 & 57.71 & -37.13 & 19718 & -7322 \\
13.80 & 12.47 & -9.80 & 4261 & -418 \\
20.10 & 11.18 & 1.16 & 3820 & 44 \\
6.98 & 3.21 & 14.46 & 1098 & 159 \\
22.67 & 11.15 & 50.73 & 3810 & 1933 \\
100.00 & 100.00 & & 34167 & -5609
\end{tabular}

TABLE 30

Employment and Components of Employment Change, Newburg Area, 1980-90

$\begin{array}{lrrrrrr} & \mathbf{1 9 8 0} & \mathbf{1 9 9 0} & \mathbf{R} & \text { N } & \text { M } & \text { S } \\ \text { Industry } & & & & & & \\ \text { Ag. \& Mining } & 105 & 203 & 98 & 13 & 65 & 20 \\ \text { Contract Construction } & 1355 & 1570 & 215 & 173 & -70 & 112 \\ \text { Manufacturing } & 19718 & 14346 & -5372 & 2520 & -7322 & -570 \\ \text { TPU \& wholesale Trade } & 4261 & 5203 & 942 & 545 & -418 & 815 \\ \text { Retail Trade } & 3820 & 4982 & 1162 & 488 & 44 & 630 \\ \text { F/I/RE } & 1098 & 1200 & 102 & 140 & 159 & -197 \\ \text { Services \& Gov't } & 3810 & 6557 & 2747 & 487 & 1933 & 327 \\ \text { TOTAI } & 34167 & 34061 & -106 & 4367 & -5609 & 1136\end{array}$

$S$ is Local Share Effect-area's competitive component.

$\mathbf{S}=\mathbf{R}-\mathbf{N}-\mathbf{M}$

Tables 31 to 33 show a slightly different story for the Newburg Area. Since half of the Newburg area is in zip code 40218 and the other half is in zip 40219, I divided the number of jobs for each industrial sector for each zip code by two and then combined the resulting numbers. This is a crude method of approximation since it assumes that jobs are equally 
distributed geographically throughout a zip code, but it is the only way to arrive at a rough job estimate for the area. Also, the estimate for the total number of jobs for the Newburg area shows wide variation between the estimates given by CBP zip code data and the census data. In addition to using the step mentioned in the previous paragraph in order to arrive at job figures for Newburg, the Dowall method that I followed estimated that in 1981 the total number of jobs in Newburg was 12,560 . For 1980, the Census data show that this area had a total of 34,167 jobs. Despite the fact that 1981 was a recession year, an economic downturn could not explain this great of a drop in the number of jobs from one year to the next. So far, the two methods have rendered numbers that were reasonably close, given that two different data sets are being analyzed. With regard to the Newburg area, perhaps the Dowall method does not accurately reflect actual job conditions in 1981 and 1994 because of the crudeness of having to arbitrarily divide zip codes into halves. By arbitrarily splitting both zip codes in half, the actual job performance of the Newburg area may not be accurately reflected in tables 31 to 33 since Newburg is only a small portion geographically of both zip codes when the two zip codes are combined. However, despite the fact that the CBP zip code numbers for the Newburg area for 1981 and 1994 do not correspond very well with the Census data, there may be some patterns that the data show that are worth examination. ${ }^{20}$ Interestingly, Table

20 Also, notice that both the 1981 and 1994 CBP zip code 138 
31 shows that between 1981 and 1994 the Newburg area saw the development of 2,900 new jobs for a growth rate of 23.09 응

TABLE 31

SHIFT-SHARE ANALYSIS

Comparison of Newburg Area to Jefferson County using CBP zip Code Data

\begin{tabular}{rrrr}
\multicolumn{2}{c}{ Employment } & \multicolumn{3}{c}{ Change 1981-94 } \\
1981 & 1994 & Absolute & Percent \\
& & & \\
1210 & 1508 & 298 & 24.63 \\
479 & 252 & -227 & -47.39 \\
15428 & 18803 & 3375 & 21.88 \\
88922 & 65021 & -23901 & -26.88 \\
16677 & 27183 & 10506 & 63.00 \\
22771 & 27838 & 5067 & 22.25 \\
56494 & 74706 & 18212 & 32.24 \\
20100 & 26002 & 5902 & 29.36 \\
67842 & 122811 & 54969 & 81.03 \\
1775 & 133 & -1592 & -89.69 \\
291698 & $\mathbf{3 6 4 3 0 7}$ & $\mathbf{7 2 6 0 9}$ & $\mathbf{2 4 . 8 9}$
\end{tabular}

Jefferson County

Agricultural services, etc.

Mining

(n)

Contract Construction

Manufacturing

TPU

Wholesale Trade

Retail Trade

F/I/RE

Services

other

Change 1981-94

Newburg Area--Part 40218 and part 40219 zip Codes

Agricultural services
Mining
Contract Construction
Manufacturing
TPU
Wholesale Trade
Retail Trade
F/I/RE
Services
Other

2555

960

883

5695

$702 \quad 706$

2347

TOTAL

45

12560

3701

5

15460

Absolute Percent

Source: 1981 and 1994 CBPs.

$$
\begin{array}{rr}
-18 & -21.69 \\
-20 & -100.00 \\
-45 & -4.81 \\
-567 & -18.16 \\
299 & 45.23 \\
261 & 41.96 \\
1672 & 41.56 \\
4 & 0.57 \\
1354 & 57.69 \\
-40 & -88.89 \\
2900 & 23.09
\end{array}
$$

This growth rate is only slightly below the county's growth

numbers are less than half those of the Coomes and Price data for each year. Therefore, there is at least some proportionality when it comes to the discrepancies between the data sets. 
rate of $24.89 \%$. Growth in TPU, wholesale trade, retail trade and services more than offset losses in agriculture, mining, construction and manufacturing.

\section{TABIE 32}

County Growth Effect, Newburg Area, 1981-94

Industry
Agricultural services, etc.
Mining
Contract Construction
Manufacturing
TPU
Wholesale Trade
Retail Trade
F/I/RE
Services
Other
TOTAL
Industry Mix Effect, Nowburg
Wholesale Trade
Retail Trade
F/I/RE
Services
Mather
Mining
Contract Construction
TPufacturing

Emp. , 1981

83

20

935

3122

661

622

4023

702

2347

45

12560

$\begin{array}{rrr}\mathbf{N} & \mathbf{R} & \mathbf{R}-\mathbf{N}=\mathbf{M}+\mathbf{S} \\ 21 & -18 & -39 \\ 5 & -20 & -25 \\ 233 & -45 & -278 \\ 777 & -567 & -1344 \\ 165 & 299 & 134 \\ 155 & 261 & 106 \\ 1001 & 1672 & 671 \\ 175 & 4 & -171 \\ 584 & 1354 & 770 \\ 11 & -40 & -51 \\ 3126 & 2900 & -226\end{array}$

\section{Area}

Distribution of Total

1981 Employment (q)

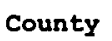

0.41

0.16

5.29

30.48

5.72

7.81

19.37

6.89

23.26

0.61

100

\section{8)}

Nowburg

Industry County Growth (8)

$\begin{array}{rr}\begin{array}{r}\text { Employment } \\ 1981\end{array} \\ 83 & -0.2 \\ 20 & -14.5 \\ 935 & -28.1 \\ 3122 & -1616.3 \\ 661 & 251.9 \\ 622 & -16.4 \\ 4023 & 295.7 \\ 702 & 31.4 \\ 2347 & 1317.6 \\ 45 & -51.6 \\ 12560 & 170\end{array}$

Table 32 shows that had this area grown at the county's growth rate, it should have produced 3,126 jobs (third column, 
top half). And the industry mix effect shows that it should have generated 170 new jobs between 1981 and 1994 (bottom half, last column). Finally, Table 33 shows that Newburg

TABIE 33

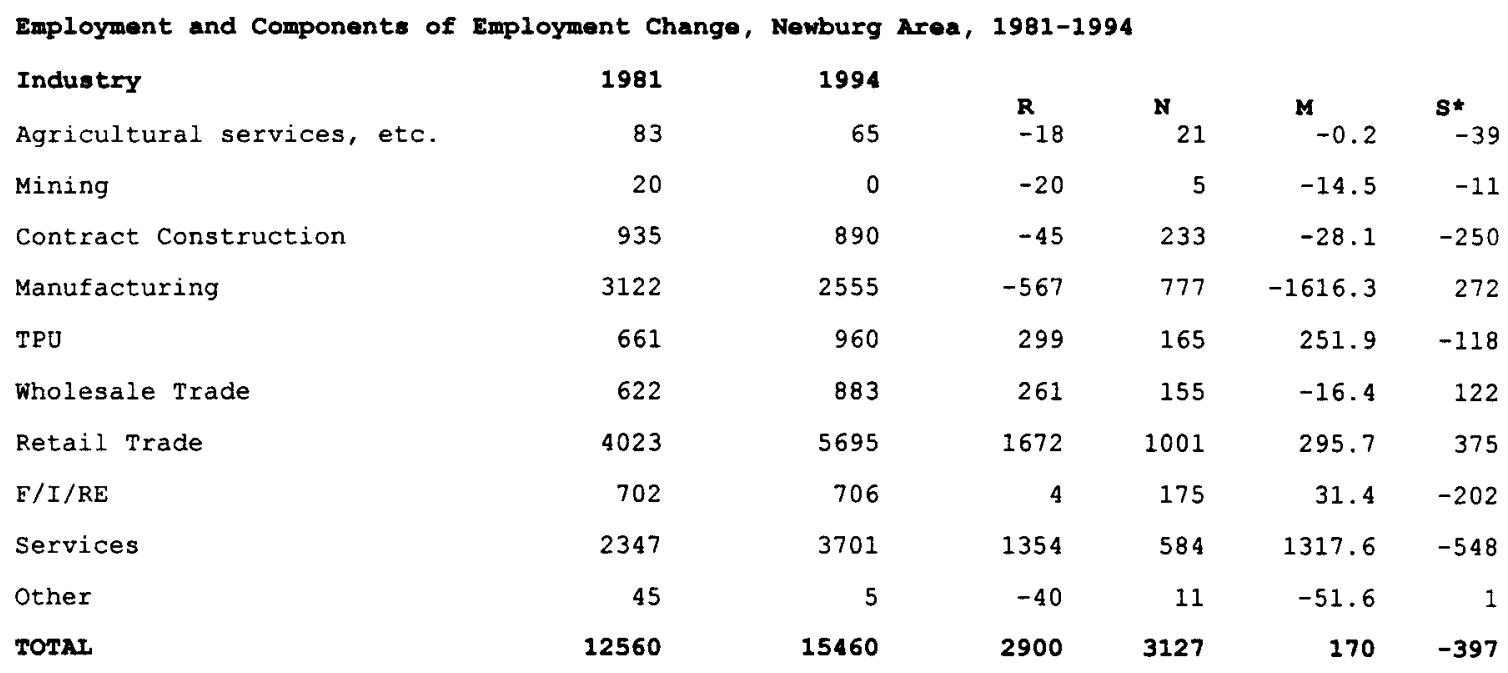

$\star S=R-N-M$

$S$ is "local share effect" showing an area's competitive component.

a negative competitive component relative to the county by failing to generate 397 jobs that it should have. This number results from the addition of 3,127 and 170 jobs ( $N$ and $M$ ) minus the actual number of jobs created--2,900 ("R").

Despite differing numbers and slightly different outcomes when it comes to competitive component, I believe that Tables 31 through 33 basically show the same thing that the Census data show. The Newburg area essentially "held its own" during the 1980s and early 1990s. That is, it either came close to matching county and industry specific growth rates, or Newburg gained just enough new jobs to roughly offset the 
jobs that it lost. This seems to have occurred despite the fact that the type of incentives offered in the $E Z$ were not offered in the Newburg area. In fact, there are no economic development incentives in place that have targeted the Newburg area. This is especially important when comparing Newburg to the original EZ. Free market forces seem to have done a better job of helping Newburg hold its own than Ez incentives did in trying to revitalize the original EZ.

How then could an area that is one of the poorest in Jefferson County (and probably the poorest outside of the City of Louisville) outperform the EZ, especially the original EZ? Most importantly, is the comparison to Newburg methodologically justified? With regard to the first question, it should be noted that there are several industrial parks in the Newburg area that are located not far from Interstate 65 and Louisville International Airport. Also, both the CBP zip code data as well as the Census data show that retailing and services grew dramatically in this area. The Newburg area takes in or is adjacent to major thoroughfares such as Bardstown Road, Newburg Road, Poplar Level Road, Indian Trail Lane, Preston Highway, Old Shephardsville Road and Outer Loop. These roads/highways have seen the proliferation of new shopping centers, restaurants, and a large shopping mall (Jefferson Mall) over the last 20 years or so. It is possible that suburban sprawl due to cheap and available land is largely responsible for this, despite the fact that the Newburg area is a lower middle class to 
lower income area. However, as Schmenner (1982) points out, taxes and regulation are only two of many considerations that a business mulls over when it decides on a location.

With regard to the second question, perhaps the accessibility to major roadways and the availability of cheap land helped the Newburg area to outperform the EZ. This may mean that despite the dour socioeconomic and demographic profiles of Newburg, it may not be fair to compare it to the EZ, especially the original EZ, because of these possible local competitive advantages. However, land is also cheap in the original EZ (see the analysis in Chapter 5), and the original $\mathrm{EZ}$ is close to Louisville's central business district as well as major interstate highways and bridges. Therefore, there must be other reasons why the EZ did not perform as well as Newburg. These reasons will be discussed in the concluding chapter of this dissertation.

\section{Job Creation in the Jeffersontown-Bluegrass Industrial Park Area versus Jefferson County, 1980 to 1990 and 1981 to 1994}

The Jeffersontown-Bluegrass Industrial Park area was included as a comparison/control community because of the possible effects that the Louisville airport expansion could have on the $\mathrm{EZ}$. Because the Bluegrass area received no incentives like the EZ or the airport area, it was chosen as a control area to be juxtaposed to the development in the airport area. Although the airport is not an industrial park, it was the closest comparison area within the EZ to Bluegrass 


\section{Industrial Park.}

The Bluegrass area shows the strongest generation of job growth compared to any area that has been looked at so far, including Louisville International Airport. Both data sets (Census and CBP data at the zip code level) show that this area not only outperformed both versions of the $E Z$, but also outperformed Newburg, Jefferson County as a whole, and the U.S. when it came to job growth rates.

Using Census data, Table 34, next page, shows that total job growth in this area was a phenomenal $94.07 \%$ between 1980 and 1990. Every major industrial classification experienced significant job growth, including manufacturing ( $+70.1 \%)$. This table shows that "Bluegrass" grew at almost 8 times the county growth rate and that each industrial sector within the Bluegrass area grew faster than each sector for the entire county with the exception of agriculture and mining.

It is not surprising then that the first part of Table 35 shows that at a county growth rate of $12.78 \%$, the Bluegrass area would have been expected to produce only 1,037 jobs (column 3). However, this area actually saw a gain of 7,635 jobs (column 4). Also, according to the industry mix effect, Bluegrass should have only gained 139 jobs due to industry-specific trends within Jefferson County (second part, 
SHIFT-SHARE ANATYSIS

Comparison of Bluegrass Industrial Park Area to Jefferson County, $1980-1990$

Industry
Ag. \& Mining
Contract Construction
Manufacturing
TPU \& Wholesale Trade
Retail Trade
F/I/RE
Services \& Gov't

TOTAL

Source: 1980 and $1990 \mathrm{CBPs}$

\begin{tabular}{|c|c|c|c|c|}
\hline \multirow[b]{2}{*}{ Industry } & \multicolumn{2}{|c|}{ Employment } & \multicolumn{2}{|c|}{ Change, $1980-90$} \\
\hline & 1980 & 1990 & Absolute & Percent \\
\hline Ag. \& Mining & 1154 & 2011 & 857 & 74.26 \\
\hline Contract Construction & 16331 & 17571 & 1240 & 7.59 \\
\hline Manufacturing & 90643 & 68569 & -22074 & -24.35 \\
\hline TPU \& Wholesale Trade & 40948 & 42168 & 1220 & 2.98 \\
\hline Retail Trade & 59633 & 67948 & 8315 & 13.94 \\
\hline$F / I / R E$ & 20718 & 26361 & 5643 & 27.24 \\
\hline Services \& Gov't & 67250 & 109962 & 42712 & 63.51 \\
\hline TOTAL & 296677 & 334590 & 37913 & 12.78 \\
\hline \multicolumn{5}{|l|}{ Source: 1980 and $1990 \mathrm{CBP}$} \\
\hline & \multicolumn{2}{|c|}{ Employment } & \multicolumn{2}{|c|}{ Change $1980-90$} \\
\hline & 1980 & 1990 & Absolute & Percent \\
\hline \multicolumn{3}{|l|}{ Bluegrass Industrial Park } & \\
\hline Ag. \& Mining & 169 & 228 & 59 & 34.91 \\
\hline Contract Construction & 649 & 1035 & 386 & 59.48 \\
\hline Manufacturing & 2147 & 3652 & 1505 & 70.10 \\
\hline TPU \& Wholesale Trade & 1304 & 3571 & 2267 & 173.85 \\
\hline Retail Trade & 1600 & 2971 & 1371 & 85.69 \\
\hline $\mathrm{F} / \mathrm{I} / \mathrm{RE}$ & 454 & 1150 & 696 & 153.30 \\
\hline Services \& Gov't & 1793 & 3144 & 1351 & 75.35 \\
\hline TOTAL & 8116 & 15751 & 7635 & 94.07 \\
\hline
\end{tabular}

Source: 1980 and 1990 Censuses.

last column). Finally, Column $S$ of Table 36 shows that the Jeffersontown-Bluegrass Industrial Park area's competitive component is $+6,459$ jobs. This can be interpreted to mean that of the 7,635 jobs gained in this area between 1980 and $1990,6,459$ of those jobs were created possibly because of some competitive advantage(s) that Bluegrass had over the rest of the county. County and industry mix effects can only account for 1,176 out of the 7,635 new jobs. From 1980 to 1990, the workforce in this area almost doubled by growing from 8,116 to 15,751 according to the Census data. 
TABLE 35

\begin{tabular}{|c|c|c|c|c|}
\hline $\begin{array}{l}\text { Jefferson Co. Growth Effect } \\
90 \\
\text { Industry }\end{array}$ & $\begin{array}{l}\text { for Bluegrass } \\
\text { Employment }\end{array}$ & Industrial Park Area & $1980-$ & \\
\hline & 1980 & $\mathbf{N}$ & $\mathbf{R}$ & $\begin{array}{l}R-N \\
=M+S\end{array}$ \\
\hline Ag. \& Mining & 169 & 22 & 59 & 37 \\
\hline Contract Construction & 649 & 83 & 386 & 303 \\
\hline Manufacturing & 2147 & 274 & 1505 & 1231 \\
\hline TPU \& Wholesale Trade & 1304 & 167 & 2267 & 2100 \\
\hline Retail Trade & 1600 & 204 & 1371 & 1167 \\
\hline$F / I / R E$ & 454 & 58 & 696 & 638 \\
\hline Services \& Gov't & 1793 & 229 & 1351 & 1122 \\
\hline TOTAL & 8116 & 1037 & 7635 & 6598 \\
\hline
\end{tabular}

Industry Mix Effect, Bluegrass Industrial Park Area, 1980-90

Distribution of Total

1980 mployment (8)

Industry

Ag. and Mining

Contract Construction

Manufacturing

TPU \& Wholesale Trade

Retail Trade

F/I/RE

Services \& Gov't

TOTAL

\begin{tabular}{rrr} 
& & \multicolumn{1}{r}{ Industry- } \\
County & Bluegrass & County \& \\
0.39 & 2.08 & 61.48 \\
5.50 & 8.00 & -5.19 \\
30.55 & 26.45 & -37.13 \\
13.80 & 16.07 & -9.80 \\
20.10 & 19.71 & 1.16 \\
6.98 & 5.59 & 14.46 \\
22.67 & 22.09 & 50.73 \\
100.00 & 100.00 &
\end{tabular}

1980

Emp. M

$169 \quad 104$

$649-34$

$2147 \quad-797$

$1304-128$

$1600 \quad 19$

$454 \quad 66$

$1793 \quad 910$

$8116 \quad 139$ 
TABLE 36

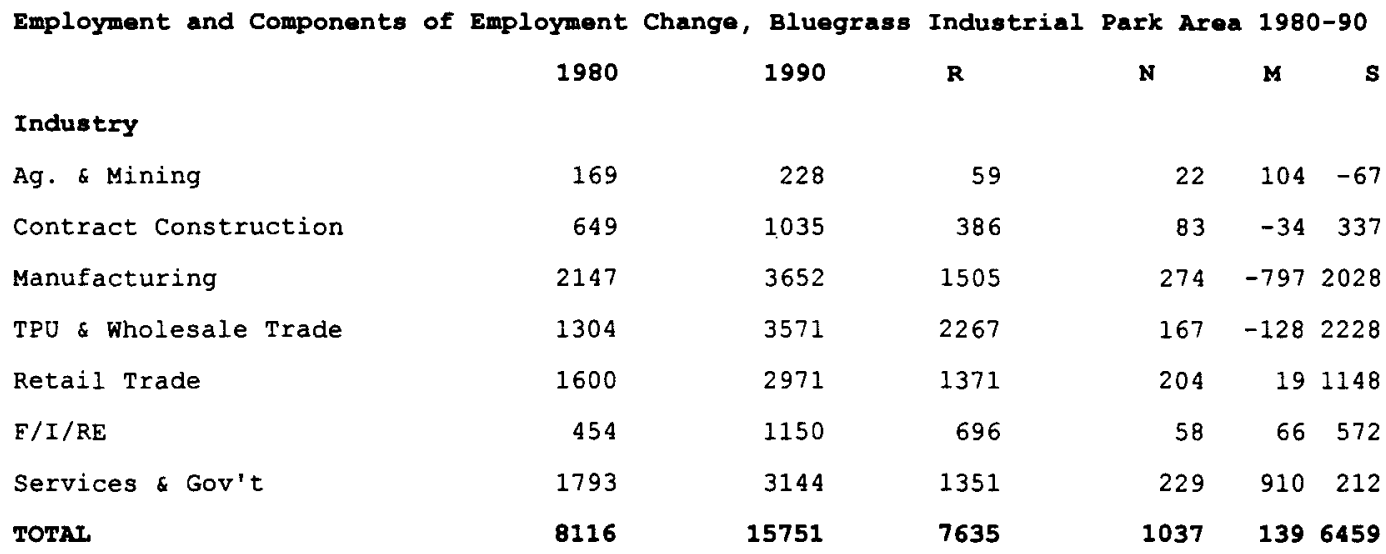

$S$ is Local Share Effect-area's competitive component.

$S=R-N-M$

Shift-share analysis of the Bluegrass area using CBP zip code level data basically corroborates and reinforces the analysis using the Census data. Table 37, part 2, shows that the area experienced a net gain of 8,005 jobs from 1981 to

TABLE 37

SHIFT-SHARE ANALYSIS

Comparison of Bluegrass Industrial Park Area to Jefferson Co. using CBP zip Code data.

\begin{tabular}{|c|c|c|c|c|}
\hline & & & Change, 19 & $981-94$ \\
\hline & 1981 & 1994 & Absolute & Percent \\
\hline Jefferson County & & & & \\
\hline Agricultural services, etc. & 1210 & 1508 & 298 & 24.63 \\
\hline Mining & 479 & 252 & -227 & -47.39 \\
\hline Contract Construction & 15428 & 18803 & 3375 & 21.88 \\
\hline Manufacturing & 88922 & 65021 & -23901 & -26.88 \\
\hline TPU & 16677 & 27183 & 10506 & 63.00 \\
\hline Wholesale Trade & 22771 & 27838 & 5067 & 22.25 \\
\hline Retail Trade & 56494 & 74706 & 18212 & 32.24 \\
\hline $\mathrm{F} / \mathrm{I} / \mathrm{RE}$ & 20100 & 26002 & 5902 & 29.36 \\
\hline Services & 67842 & 122811 & 54969 & 81.03 \\
\hline Other & 1775 & 183 & -1592 & -89.69 \\
\hline TOTAL & 291698 & 364307 & 72609 & 24.89 \\
\hline
\end{tabular}


TABLE 37, CONTINUED.

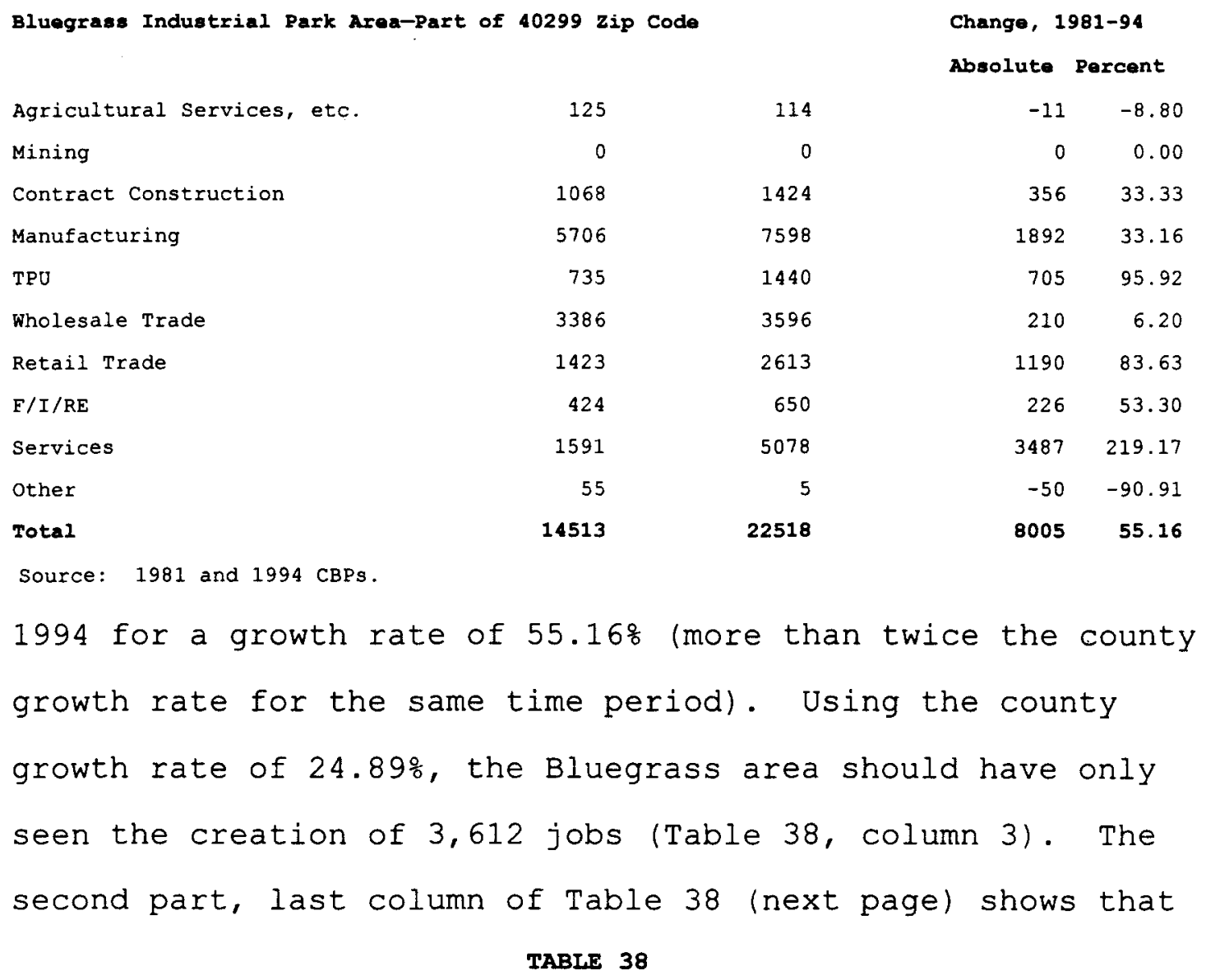

County Growth Effect, Bluegrass Industrial Park Area, 1981-94

Industry

Employment

Agricultural Services, etc.

Mining

Contract Construction

Manufacturing

TPU

Wholesale Trade

Retail Trade

F/I/RE

Services

Other

Total

$$
\begin{array}{r}
\text { Employment } \\
1981
\end{array}
$$

125

0

1068

5706

735

3386

1423

424

1591

55

14513
N

31

0

266

1420

183

843

354

106

396

14

3612
R

$\mathrm{R}-\mathrm{N}=\mathrm{M}+\mathrm{S}$

$\begin{array}{rr}-11 & -42 \\ 0 & 0 \\ 356 & 90 \\ 1892 & 472 \\ 705 & 522 \\ 210 & -633 \\ 1190 & 836 \\ 226 & 120 \\ 3487 & 3091 \\ -50 & -64 \\ 8005 & 4393\end{array}$


Table 38, CONTINUED.

Industry Mix Effect, Bluegrass Industrial Park Area

Distribution of Total

1981 Employment (q)

Industry

County

Bluegrass

Agricultural Services, etc.

0.41

0.86

0.16

0.00

Mining

5.29

7.36

30.48

39.32

Manufacturing

5.72

5.06

TPU

Wholesale Trade

7.81

23.33

Retail Trade

19.37

9.81

F/I/RE

6.89

2.92

Services

23.26

10.96

other

0.61

0.38

Total

100

100

$\begin{array}{rrr}\begin{array}{r}\text { Industry- } \\ \text { County \& }\end{array} & \begin{array}{r}\text { Emp. } \\ 1981\end{array} \\ -0.26 & 125 & -0.3 \\ -72.28 & 0 & 0.0 \\ -3.01 & 1068 & -32.2 \\ -51.77 & 5706 & -2953.9 \\ 38.11 & 735 & 280.1 \\ -2.64 & 3386 & -89.3 \\ 7.35 & 1423 & 104.5 \\ 4.47 & 424 & 19.0 \\ 56.14 & 1591 & 893.1 \\ -114.58 & 55 & -63.0 \\ & 14513 & -1842\end{array}$

Source: 1981 and 1994 CBPs.

the Bluegrass area should have lost 1,842 jobs due to the county's industry mix effect. Yet the negative industry mix

TABLE 39

\begin{tabular}{|c|c|c|c|c|c|c|}
\hline $\begin{array}{l}\text { Employment and Components of } \\
1981-94 \\
\text { Industry }\end{array}$ & $\begin{array}{c}\text { Employment } \\
1981\end{array}$ & $\begin{array}{c}\text { Change, Bluegrass } \\
1994\end{array}$ & $\begin{array}{l}\text { Industrial } \\
\mathbf{R}\end{array}$ & $\begin{array}{l}\text { Park } \\
\text { N }\end{array}$ & Area, & *s \\
\hline Agricultural Services, etc. & 125 & 114 & -11 & 31 & -0.3 & -42 \\
\hline Mining & 0 & 0 & 0 & 0 & 0 & 0 \\
\hline Contract Construction & 1068 & 1424 & 356 & 266 & -32.2 & 122 \\
\hline Manufacturing & 5706 & 7598 & 1892 & 1420 & -2953.9 & 3426 \\
\hline TPU & 735 & 1440 & 705 & 183 & 280.1 & 242 \\
\hline Wholesale Trade & 3386 & 3596 & 210 & 843 & -89.3 & -543 \\
\hline Retail Trade & 1423 & 2613 & 1190 & 354 & 104.5 & 731 \\
\hline $\mathrm{F} / \mathrm{I} / \mathrm{RE}$ & 424 & 650 & 226 & 106 & 19 & 102 \\
\hline Services & 1591 & 5078 & 3487 & 396 & 893.1 & 2198 \\
\hline Other & 55 & 5 & -50 & 14 & -63 & -1 \\
\hline Total & 14513 & 22518 & 8005 & 3613 & -1842 & 6235 \\
\hline
\end{tabular}

$S$ is Local Share Effect-area's competitive component.

$\star S=R-N-M$ 
effect was not enough to slow down growth in the Bluegrass area. In seeing 8,005 jobs created between 1981 and 1994, Bluegrass could claim that 6,235 of those jobs were created due to some possible competitive advantage(s) that it had over the county (Column S, Table 39).

Once again, " $S$ " is only a residual number and there are limits as to what can be inferred from its sign (positive or negative) and its magnitude. Nevertheless, both data sets are saying that after controlling for county growth trends and industry-specific trends, for whatever reason, the Jeffersontown-Bluegrass Industrial Park area was a net job gainer in the 1980 s and early 1990s. One could infer from the Census data that around $85 \% \quad(=6,459 / 7,635 \times 100)$ of the new jobs created in this area were possibly due to some unique feature(s) special to the area. Almost the same could be argued using the $\mathrm{CBP}$ data. Around $78 \%(=6,235 / 8,005 \times 100)$ of the new jobs gained in the Bluegrass area between 1981 and 1994 could have possibly been gained due to some attributes of Bluegrass that made it desirable for job and business growth. It seems unlikely that such robust job growth results could have been caused by random chance.

What has caused the Jeffersontown-Bluegrass Industrial Park area to grow at such a fast pace over the years? Why did it greatly outperform the EZ and the airport, much less Jefferson County? As mentioned earlier, Schmenner (1982) and others who have studied business site location decisions have found that tax incentives and regulatory relief are only two 
of a long list of factors that businesses consider when making decisions. In fact, many firms may be willing to locate to a relatively high taxing and regulatory jurisdiction if these burdens are offset by such factors as a high amount of local amenities, low crime rates, good schools and colleges, and an educated, skilled labor force.

With regard to the Bluegrass area, it must be remembered that it did not receive any type of economic development stimulus similar to that received by the Ez or the airport. It appears reasonable to argue that private market forces had a great impact on this area. News reports indicate a phenomenal growth in housing in this area over the last two decades because of an abundance of undeveloped and available land (Stahl, 1997 and Stahl, 1997). Also, one can see rapid growth in this area from the Census Bureau data shown in Chapter 5. Over the last two decades, the City of Jeffersontown, home of Bluegrass Industrial Park, has gone from a semi-rural, underdeveloped portion of eastern Jefferson County to what would now be called an edge-city. Legally, Jeffersontown is a fourth-class city as defined by the Kentucky Constitution. It has its own police, fire, sanitation and public works departments just like many larger cities in the Commonwealth. As with other portions of eastern Jefferson County, this area has grown dramatically over the last 20 years or so (Coomes and Price, 1994). As mentioned in an earlier footnote, OED claims that 18,000 new jobs were created in Louisville's EZ between July 
1983 and June 1996 (Shafer, 1996). However, if OED figures from EZ Annual Reports of jobs created are summed, then the number of new jobs created by the EZ from 1983 to June 30, 1996 is 19,664 . OED attributes this discrepancy to changes made in record-keeping in 1992 .

A survey of Ez certified firms done by the University of Louisville's Urban Studies Institute (USI) projected a different amount for jobs created--5,760. However, respondents also credited the $\mathrm{EZ}$ incentives with "saving" 3,152 jobs and creating or saving 6,333 jobs. Without regard to incentives, the 851 companies interviewed indicated that their workforce had grown by a net of 13,271 employees since the companies had acquired EZ certification. However, not all 842 companies had been certified at the time that the zone had come into existence. Some companies had been certified since 1983 whereas others had only been certified for a couple of years.

\section{Unfortunately, United Parcel Service (UPS) was not} interviewed. According to a phone conversation in October 1996 that I had with Ken Shapero of UPS's Public Relations Office, in 1981 UPS employed 900 workers. As noted earlier in this dissertation, UPS became part of the EZ in 1986. Ten years later, Shapero reported that UPS employed around 14,000 people, $80 \%$ of whom are part-time workers. Adding 14,000 to the 13,271 jobs that respondents reported would greatly boost the number of jobs created within the EZ without regard to incentives. 
Since there does not appear to be any firm estimate of the number of jobs created due to EZ incentives, this analysis will use OED's figure of 18,000 new jobs created between 1983 and 1996. This gives OED the "benefit of the doubt" when it comes to establishing a hard number on the number of jobs created within the EZ from 1983 to 1996. Also, these are the only official numbers that exist. This number along with other possible figures for job creation and/or retention will be used in a later chapter that evaluates the costeffectiveness of the EZ.

Finally, according to analysis of the USI survey data, only $26.5 \%$ of the survey's respondents said that the EZ incentives had helped to save jobs, and a little less than half of the respondents (48.5\%) said that $\mathrm{EZ}$ incentives had helped to create new jobs. These percentages lend some credence to the results that $\mathrm{EZ}$ incentives can be credited with only creating and/or saving 6,333 jobs. This number would only be at best one-third of OED's claim of 18,000 jobs created and thousands of more jobs saved (which in 1990 was supposed to have been 24,000 jobs (OED Press Release, The Louisville Enterprise Zone: Louisville's $\$ 1$ Billion Success Story, 1990)). ${ }^{21}$ Certainly, the results of the survey seem to

21 OED annual reports only gave numbers for jobs saved or retained for only a handful of years out of their thirteen fiscal year (FY) reports (FYs 1983-84 to 1995-96). For FY 1987-88, OED claims that EZ incentives helped to retain 11,646 jobs. For FYs 1989-90, 1992-93, 1994-95, and 1995-96, OED claims that $\mathrm{EZ}$ incentives helped to retain $6,003,1,653,282$, and 528 jobs, respectively. There are no job numbers given for other fiscal years, so there is no hard cumulative number for the number of jobs retained due to $\mathrm{EZ}$ incentives over the 153 
further diminish the claims of success by OED.

\section{Summary}

In looking back at the results of analyses conducted in Chapters 5 and 6 as well as this chapter, there are strong and reasonable doubts about how well the EZ program did with regard to economically revitalizing the full-size Ez or any portion of it. Chapter 5 showed that EZ areas, especially the original EZ, failed to improve socially and economically at a rate better than the Newburg area. Chapter 6 showed that, with the exception of the Louisville airport, not even strong job growth throughout Jefferson County was enough to pull most of the EZ area beyond a stagnant level of job growth at best. And in regard to the airport, there were probably important factors other than EZ incentives that helped it to grow. Finally, this chapter showed that two areas which did not receive $\mathrm{EZ}$ incentives at least matched or outperformed $\mathrm{EZ}$ counterparts when it came to job growth, thus suggesting that market forces might have been as effective, if not more effective, than any type of economic development policy intervention.

With this in mind, the issue of the cost-effectiveness of the Ez program must be analyzed. For even if program goals were not completely met, perhaps program costs could be justified for whatever small gains were made in the EZ when 
compared to program benefits. That is to say, if one argues that things could have been worse in the EZ area from 1983 to 1996 without the intervention of EZ incentives, then the program could be called a modest success, especially if program benefits outweighed program costs. 


\section{Costs and Benefits of the EZ and an Analysis of How Well it Helped Disadvantaged Workers}

\section{Introduction}

At the heart of program evaluation is an assessment of the cost-effectiveness of any policy intervention (Gramlich, 1981; Haveman and Margolis, 1983; Rossi and Freeman, 1983, Ch. 8; Stiglitz, 1988, Ch. 10; Schofield, 1987; and Weimer and Vining, 1992, Ch. 9). This chapter examines the costs and benefits associated with the Louisville and Jefferson County EZ program when it comes to job creation and retention and capital investment. Monitoring and evaluation are important components in the program planning process. Outcomes should be measured against costs to see if the program is performing efficiently and effectively. High costs that indicate program inefficiency can lead to either relevant changes, or to the formulation of a completely different program if costs are deemed too high for given outcomes.

One problem consistently noted in the literature on the analysis of program cost-effectiveness is the difficulty of measuring outcomes in governmental and non-profit programs. There are issues of program externalities, shadow-pricing, opportunity costs and equity to name but a few (Stiglitz, 1988). For instance, the direct benefits to recipients and costs of many government welfare programs such as AFDC are 
well-documented. But it is much more difficult to measure the gain to society as a whole for such a program. In fact, the belief by many that welfare programs yield fewer benefits to society, if any, than was previously believed when these programs were first created, has led to a movement to drastically curtail these programs and their funding. Therefore, cost-effectiveness analysis outside of the private sector can be a very complicated and politicized undertaking. With regard to the Louisville and Jefferson County EZ program, the problems of weighing program costs and benefits are compounded by the lack of monitoring and data collection done by EZ authorities. The lack of monitoring provisions were discussed in detail earlier in Chapter 3. Because monitoring and data collection were not fully and adequately undertaken until mid-1992, data for all but four of the total years considered in this study are either not available or incomplete. For these reasons, many assumptions and estimates had to made in order to come up with the dollar amounts used in the cost-effectiveness analysis presented in this chapter.

Finally, since perhaps the biggest reason for creating EZs was to provide jobs for the urban poor (Hall, 1977), the ability of the EZ program to generate such jobs will be evaluated by looking at that portion of the EZ program that granted tax credits for firms that hire "disadvantaged workers." These issues were described earlier in Chapters 3 and 4 .

It appears from the analysis thus far that the EZ 
program has not been a good generator of net new jobs, with perhaps the exception of the Louisville airport. ${ }^{22}$ Also, the EZ program has not been completely successful with regard to the social and economic revitalization of $\mathrm{EZ}$ neighborhoods when compared to a control community. The rest of this chapter will try to establish whether the costs incurred in EZ program implementation were at least matched if not offset by any benefits derived from the program.

\section{EZ Program Costs}

As outlined in Chapter 3, EZ certified firms were granted fee and tax waivers in return for engaging in certain hiring practices and/or investment practices. Among the incentives were the following: 1) tax exemptions for capital gains; 2) special net operating loss write-offs from business income taxes; 3) exemptions on state motor vehicle usage taxes; 4) waiver of state sales taxes on the purchase of building materials, equipment, and machinery; and 5) waiver of local government inspections, building and permit fees.

Table 40 shows the estimated tax revenue losses resulting from EZ firms taking advantage of capital gains exemptions: $\$ 520,310.19$. This incentive was eliminated by July, 1992. As the table shows, it is estimated that only around a half million dollars was lost to this incentive. Perhaps this is because 10 years (1983 to 1992) is not enough

22 Recall that the airport received millions of dollars of money from both state and federal sources in order to grow and expand. These expenditures were not a part of either the EZ 
time for a significant amount of capital appreciation in many assets. In any event, it was recommended that the incentive be dropped because it did not seem to be making a significant contribution to capital formation or job creation ( $L R C$ Memorandum, No. 460, 1991).

The only definite number for this table was for the Fiscal Year (FY) 1987-88 as determined by the Kentucky Revenue Cabinet (LRC Memorandum, No. 460). Because records for other years were not kept, and since the incentive was abolished by the time that better monitoring of the program was in place, estimates for other years in Table 40 were determined by multiplying the FY 1987-88 amount $(\$ 75,957.69)$ by a GDP deflator listed in the 1992 and 1995 editions of the Statistical Abstract of the United States (U. S. Commerce Department, 1992 and 1995). ${ }^{23}$ For the first fiscal year after FY 1987-88, an estimate for FY 1988-89 was calculated by multiplying $\$ 75,957.69$ by the GDP deflator number for FY $1988-$ 89. Then $\$ 78,966.00$ was multiplied by the deflator for the next year in order to get the following year's estimated amount. This iteration was used up to FY 1991-92. For fiscal years before FY 1987-88, an estimate for FY 1986-87 was calculated by multiplying $\$ 75,957.69$ by the GDP deflator for that year (FY 1986-87). Then the $\$ 75,957.69$ was multiplied by the deflator for the previous year, and so on until FY 1983-

program or the EZ legislation.

23 The base year for the deflator is 1987 . This, of course, assumes that the EZ grew at a rate comparable to real U. S. Gross Domestic Product. This was probably not so, but absent any other method of estimation, this was the best technique 
86. Also, as in other similar tables in this chapter, estimates for the first three FYs were divided by seven in order to reflect the original zone's small size. ${ }^{24}$

TABLE 40

Estimated taxes lost to capital gains exemptions

(Incentive was eliminated in 1992)

$\begin{array}{lll}\begin{array}{l}\text { Fiscal } \\ \text { Year }\end{array} & \text { Amount } & \text { GDP Deflator } \\ & & \\ 1983-84 & \$ 9,548.97 & 0.88 \\ 1984-85 & \$ 9,874.50 & 0.91 \\ 1985-86 & \$ 10,200.04 & 0.94 \\ 1986-87 & \$ 73,678.96 & 0.97 \\ 1987-88 & \$ 75,957.69 & 1.00 \text { Base Year } \\ 1988-89 & \$ 78,996.00 & 1.04 \\ 1989-90 & \$ 82,793.88 & 1.09 \\ 1990-91 & \$ 86,591.77 & 1.14 \\ 1991-92 & \$ 92,668.38 & 1.22 \\ & & \end{array}$

SOURCES: A dollar amount for FY 1988-89 was determined by the Legislative Research Commission with assistance from the Kentucky Revenue Cabinet. Because records for other years were not kept, estimates for other years were determined by adjusting the FY 1988-89 amount by a GDP deflator (1995 statistical Abstract of the U. S. and

1992 statistical Abstract of the U.S.). Because of the zone's small size during the first three fiscal years of its existence, estimates for FYs 1983-84 to 1985-86 were multiplied by oneseventh. This was a crude but necessary procedure.

Table 41 shows the estimated state tax revenues lost due to EZ certified businesses being allowed to deduct net operating losses (NOL) at full value over the 20 year life of

available.

24 This is a crude yet necessary adjustment. As the zone grew and became more geographically dispersed, the sheer number of businesses eligible to participate in the EZ sky-rocketed. Some adjustment had to be made for the first two EZs small sizes: 3.75 and 6.75 square miles, respectively. 160 
the EZ, that is until the year 2003. For most firms, these losses are usually capped and can only be carried forward for a certain period of time. Allowing such losses to be matched against future net profits was supposed to allow fledgling companies a chance to grow and thrive after incurring initial net losses. Since most new businesses incur net losses in their first few years, this provision of the law was enacted to encourage entrepreneurship.

Like Table 40, the only available and certain dollar figure for Net Operating Loss Carryforward was for FY 1987-88. Therefore, the same estimation procedures used in Table 40 were also used in Table 41.

\section{TABIE 41}

Estimated Net Operating Loss Carryforward (write-offs)

(incentive was eliminated in 1992)

Fiscal

Yar

$1983-84$

$1984-85$

1985-86

1986-87

1987-88

1988-89

1989-90

1990-91

1991-92

TOTAL

\section{Amount}

$\$ 725,607.02$

$\$ 750,343.61$

$\$ 775,080.23$

$\$ 5,598,717.80$

$\$ 5,771,874.00$

$\$ 6,002,749.00$

$\$ 6,291,342.70$

$\$ 6,579,936.40$

$\$ 7,041,686.30$

$\$ 39,537,337.06$
GDP Deflator
0.88
0.91
0.94
0.97
1.00 Base year
1.04
1.09
1.14
1.22

SOURCE: Estimates based upon Kentucky Revenue Cabinet and Legislative Research Commission disclosed amount for FY 1988-89.

Other years were estimated by using a GD deflator with a base year of 1987 on the

FY 1988-89 dollar amount (1995 statistical Abstraç of the United states, Table 771,

p. 505 and 1992 Statistical Abstract of the United States, Table 752, P. 481).

Also, for the first three fiscal years, estimates were reduced by one-seventh

because of the zone's original small size. No records existed for other years,

so this method was employed. 
Estimated tax revenues lost due to this provision of the EZ law were considerable: $\$ 39,537,337.06$ over a 9 year period. Despite the fact that this incentive was originally seen as encouraging small business formation, it too was eliminated as a tax incentive at the end of FY 1991-1992. The Kentucky State Legislature's subcommittee looking into the state EZ program felt that while this aspect of the EZ law may have been helping small business formation, there was also the possibility and some evidence in the local press (Heath, 1991) to suggest that large, already well-established corporations were taking advantage of this incentive. It was also felt that there was no direct way to link the costs of this incentive with actual job creation (LRC Memorandum, No. 460).

Table 42 shows the estimated costs of motor vehicle taxes foregone by the state because of EZ incentives. Because the Kentucky Revenue Cabinet only had the actual dollar amounts and the number of vehicles exempted for FY 1988-89 and FYs 1991-92 to 1994-95, it was necessary to estimate the data and dollar values for other years by first calculating the approximate percentage that EZ vehicles were of all vehicles registered in Jefferson County for the years for which we had solid numbers. For the years given, the average was approximately $.33 \%$ of $1 / 3$ of $1 \%$. The number of vehicles exempted from either full or partial motor vehicle usage taxation for the years for which we had no number of vehicles was then estimated by multiplying .0033 by the total number of registered motor vehicles in Jefferson County for those years 
(Source: 1985, 1990 and 1994 Kentucky Handbook of Economic Statistics). Because of poor EZ administration and data collection, this was a crude but necessary method of estimation.

Once the number of exempted $\mathrm{EZ}$ vehicles were estimated (see Number of Vehicles) the amount of taxes lost per vehicle was calculate (Taxes lost per Vehicle). Using the actual number of vehicles for the four years for which there were data (FYs 1991-95), taxes lost per vehicle for those four years was calculated by dividing the actual amount of taxes foregone by the number of vehicles. Next, an amount for the taxes lost per vehicle was estimated for FY 1990-91 by dividing taxes lost per vehicle for FY 1991-92. For FY 198990 the same was done but the resulting number was multiplied by $5 / 6$. This was done because state sales taxes were raised from 5 cents per dollar to 6 cents per dollar on July 1, 1990. Therefore, an adjustment had to be made because there was a change in tax rates.

Taxes lost per vehicle for FY 1989-90 were then adjusted downward by 1.08 in order to arrive at a value for 1988-89. This method was repeated for each year until FY 1985-86 and before. For these periods, each number calculated was divided by 7 in order to adjust for the size of the EZ during this time period.

Finally, the Taxes Foregone for each FY in Table 42 were derived by multiplying the Number of Vehicles by Taxes lost per Vehicle. Next, these amounts were summed to arrive at 
$\$ 13,911,208.60$. Recall from Chapter 3 that this provision of the EZ law was amended so that beginning in July 1992 only the first $\$ 20,000$ of passenger vehicle (e.g., sedans, station wagons, etc.) values were exempted from the tax. This was done because some business owners in the EZ had registered high priced luxury cars for their personal use in the name of their business and had not been paying any taxes on these cars (Heath, 1991). In that case, and if such abuses of the law were widespread, then the dollar amounts estimated for the years prior to 1991 may actually be higher.

TABLE 42

\begin{tabular}{|c|c|c|}
\hline $\begin{array}{l}\text { Fiscal } \\
\text { Year }\end{array}$ & $\begin{array}{l}\text { Number of } \\
\text { Vehicles }\end{array}$ & Taxes Foregone \\
\hline $1983-84$ & 217 & $\$ 87,212.30$ \\
\hline $1984-85$ & 208 & $\$ 90,700.48$ \\
\hline $1985-86$ & 211 & $\$ 98,912.58$ \\
\hline $1986-87$ & 1486 & $\$ 752,346.94$ \\
\hline $1987-88$ & 1504 & $\$ 822,387.20$ \\
\hline $1988-89$ & 1538 & $\$ 908,440.00$ \\
\hline $1989-90$ & 1555 & $\$ 991,623.50$ \\
\hline $1990-91$ & 1528 & $\$ 1,262,892.00$ \\
\hline $1991-92$ & 1882 & $\$ 1,679,835.00$ \\
\hline $1992-93$ & 1590 & $\$ 1,521,022.00$ \\
\hline $1993-94$ & 1613 & $\$ 1,635,806,00$ \\
\hline $1994-95$ & 1447 & $\$ 1,915,507.00$ \\
\hline $1995-96 *$ & 1500 & $\$ 2,144,523.60$ \\
\hline
\end{tabular}

$\begin{array}{lll}\begin{array}{l}\text { Taxes } \\ \text { lost }\end{array} & \begin{array}{l}\text { Tot. MV } \\ \text { Jeff Co. } \\ \text { Per } \\ \text { Vehicle }\end{array} & \begin{array}{l}\text { Registered } \\ \text { \& of Co. } \\ \text { Registered }\end{array} \\ \$ 401.90 & 460394 & \\ \$ 436.06 & 441767 & \\ \$ 468.78 & 447654 & \\ \$ 506.29 & 450296 & \\ \$ 546.80 & 455739 & \\ \$ 590.50 & 456306 & 0.34 \% \\ \$ 637.70 & 471131 & \\ \$ 826.50 & 462694 & \\ \$ 892.58 & 464596 & 0.40 \% \\ \$ 956.62 & 463575 & 0.34 \% \\ \$ 1,014.14 & 464697 & 0.35 \% \\ \$ 1,323.78 & 445855 & 0.32 \% \\ \$ 1,429.68 & & \end{array}$

Avg. . $33 \%$

TOTAL

$\$ 13,911,208.60$

* Number of vehicles for this year is estimated.

Source: Kentucky Revenue Cabinet, Dept. of Motor Vehicles and $K_{Y}$. Handbook of Economic statistics.

The next table shows the estimated amount of sales taxes lost due to exemptions on the purchase of building materials, 
equipment, and machinery. The Kentucky Revenue Cabinet . provided dollar amounts for actual sales taxes lost for FYs 1991-92, 1992-93, 1993-94 and 1994-95. There were no records for other years.

As an approximation of the taxes lost for other years, the following method was used. First, the amount of actual taxes lost for each of the four years was divided by the amount of sales taxes collected for Jefferson County for each of those same four years (Source: Kentucky Revenue Cabinet's Annual Report). When averaged, sales taxes lost each year due to EZ incentives as a percentage of all Jefferson County sales taxes was around $3.05 \%$

Next, sales taxes lost for other years were calculated by multiplying .0305 by the total sales taxes collected in Jefferson County for those years. The only year for which an amount was not reported was for FY 1987-88. Taxes for this year were estimated by averaging sales tax collections for FYs 1986-87 and 1988-89. Finally, sales taxes lost for FY 1995-96 was estimated by averaging the sales taxes lost for the four previous fiscal years. Total sales tax revenues for Jefferson County for FY 1996-96 were arrived at by dividing this estimate of sales taxes lost $(\$ 10,218,415.00)$ by .0305 . When added, the total amount of taxes foregone due to sales tax waivers from FY 1983-84 to FY 1995-96 was estimated at $\$ 91,218,145.39$.

The methodology employed to arrive at the numbers displayed in Table 43 was a crude but necessary one given the 
sparse data collected by the Commonwealth of Kentucky. It should also be noted that this incentive was the only original incentive to remain unchanged since 1982 .

TABLE 43

Estimated Sales Taxes lost due to exemptions on the purchase of building materials, equipment and machinery.

\begin{tabular}{lr} 
Fiscal & \multicolumn{2}{l}{$\begin{array}{l}\text { Sales taxes 10st } \\
\text { in Ent. Zone }\end{array}$} \\
& \\
$1983-84$ & $\$ 749,989.02$ \\
$1984-85$ & $\$ 830,037.40$ \\
$1985-86$ & $\$ 947,012.10$ \\
$1986-87$ & $\$ 6,754,709.83$ \\
$1987-88 \star$ & $\$ 7,095,013.70$ \\
$1988-89$ & $\$ 7,435,317.63$ \\
$1989-90$ & $\$ 8,105,150.73$ \\
$1990-91 \star \star$ & $\$ 8,208,727.97$ \\
$1991-92$ & $\$ 11,852,997.00$ \\
$1992-93$ & $\$ 12,490,748.00$ \\
$1993-94$ & $\$ 6,976,430.00$ \\
$1994-95$ & $\$ 9,553,597.00$ \\
$1995-96$ & $\$ 10,218,415.00$ \\
& \\
Total & $\$ 91,218,145.39$
\end{tabular}

Total state sales taxes

for Jefferson Co.

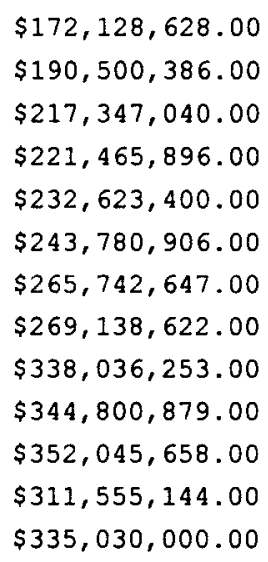

3.518

3.628

$1.98 \%$

3.078

AVG : $3.05 \%$

Source: Kentucky Revenue Cabinet and estimates based on Rev. Cabinet data. *No data for sales taxes collected in Jefferson Co. for FY 87-88 was ever compiled according to Gene Brown of Rev. Cabinet.

Dollar values are estimates.

* Sales tax rate raised from 5 cents to 6 cents per dollar on July 1, 1990.

Besides these incentives, the state was also doing things in the Louisville EZ which may have had an impact upon local economic development. Table 44 shows a listing of Kentucky Economic Development Bonds issued by the state which were for projects located in the EZ. Although not part of the 
EZ program, these bonds must be considered as a possible stimulus to EZ job creation and retention. Therefore, they should be added to the costs of job creation and retention within the EZ. By the same token, the airport project funded by these bonds could be considered an overall public good or asset.

TABLE 44

Kentucky Economic Development Bonds used in Enterprise zone Area

Year Issued

1984
1986
1990
1990
1991
1991
1991
1992
1992
1993
1993
1994
Total
Amount

$$
\begin{array}{r}
\$ 10,500,000.00 \\
\$ 3,000,000.00 \\
\$ 300,000.00 \\
\$ 1,000,000.00 \\
\$ 1,000,000.00 \\
\$ 50,000,000.00 \\
\$ 725,000.00 \\
\$ 250,000.00 \\
\$ 500,000.00 \\
\$ 750,000.00 \\
\$ 2,170,000.00 \\
\$ 600,000.00 \\
\$ 70,795,000.00
\end{array}
$$

Project Name

Louisville Airport

Riverport Industrial Part

Riverport Industrial Park

Washington Apparel Group

Henry Vogt Machine Co.

Louisville Airport

Monfort, Inc.

B. F. Goodrich $\mathrm{Co}$.

Kroger

Kroger

Ford Motor Co.

Hillerich and Bradsby

Source: Dan Jacovitch, Kentucky Legislative Research Commission.

Unfortunately, despite repeated attempts to collect data from the LRC and other state agencies on the amount of interest paid on these bonds as well as attempts to determine which amounts had been retired and which were still outstanding, I had to settle upon the face value of the bonds as an economic development cost. Therefore, these figures can be considered a low estimate.

Notice that $\$ 60,500,000$ of the $\$ 70,795,000$ in bonds issued was devoted to the development of Louisville International Airport. Along with millions of dollars of Federal Aviation Administration funding, such an infusion of 
money enabled the airport to add an extra runway and other new facilities. Referring back to the shift-share analysis of Chapter 6, this probably provides an explanation of why the airport did better than the rest of the EZ when it came to job creation. Also, the addition of this runway allowed UPS to expand and hire more workers. It is doubtful that EZ incentives alone would have been enough to allow UPS to grow from roughly 1,000 employees in 1981 , to 8,412 in 1990 , and to nearly 14,000 by september 1996, approximately one year after the second runway was opened (interview with UPS public relations, $10 / 7 / 96)$. In fact, UPS's decision to stay and hire more workers in the Louisville area was primarily based on the condition that Louisville's airport was to be expanded and enhanced (interview, 1996).

Finally, it should be noted that in addition to $\mathrm{EZ}$ incentives and development bonds, the Commonwealth of Kentucky also has various other incentives at its disposal in order to recruit new firms to the state or to help existing firms in the state. The Kentucky Industrial Development Act and the Kentucky Job Development Act were passed by the 1992 General Assembly. These acts contained incentives that allowed companies payroll tax credits for workers hired. However, according to Kentucky Cabinet for Economic Development records, out of the millions of dollars authorized for companies to take the tax credit, only a little over $\$ 3,000$ in credits have been claimed to date. Perhaps many firms are waiting to take the tax credits when earnings become higher, 
but this is only speculation.

In addition to state incentives, KRS 154.45 allowed each EZ designated area a certain amount of latitude in offering their own local incentives. As mentioned in Chapter 3, the City of Louisville and Jefferson County waive or discount inspections, permits and license fees for certified EZ firms. Table 45 shows estimates of what the city has foregone in fee revenues over the years: $\$ 569,194.94$.

TABLE 45

Estimates of Building Permit Fees Foregone, 1983-96

Fiscal Year

1983-84

$1984-85$

$1985-86$

$1986-87$

$1987-88$

$1988-89$

$1989-90$

$1990-91$

$1991-92$

1992-93

1993-94

1994-95

1995-96

TOTAI
Amount

$\$ 2,597.95$

$\$ 2,952.22$

$\$ 3,244.20$

$\$ 24,154.92$

$\$ 24,906.10$

$\$ 24,906.10$

$\$ 25,902.35$

$\$ 28,233.56$

$\$ 29,997.71$

$\$ 81,647.25$

$\$ 90,965.25$

$\$ 166,001.66$

$\$ 63,685.67$

$\$ 569,194.94$
GDP Deflator

.88

.91

.94

.97

1.00

1.04

1.09

Source: City of Louisville Department of Inspections, Permits and Licenses (IPL) provided dollar amounts for FYs 1990-91 to 1995-96. Other years were estimated using GDP deflator numbers used in Tables $8-1$ and 8-2. Once again, the estimates for the first three years of the EZ were divided by seven to reflect the small size of the original Ez.

The total estimated amount of $\$ 569,199.08$ is probably close to being correct because paul Nicholson of IPL said in June 1996 interview that Ez permit fee waivers and discounts had cost IPL about $\$ 40,000$ to $\$ 50,000$ per year on average since the EZ began in 1983 .

Because of a lack of diligent record-keeping, actual dollar amounts for revenues foregone are only known for FYs 1990-91 to 1995-96. The other figures listed in Table 45 are estimates based upon the GDP deflator used in previous tables. The amount for FY 1990-91 was divided by 1.09 to arrive at $\$ 25,902.49$ for FY 1989-90. Then the estimated amount for FY 1989-90 was divided by the GDP deflator for the previous year 
in order to arrive at the estimated amount of fees foregone for FY 1988-89. The same process was repeated until an estimate was created for FY 1986-87. Then the estimated amount for FY 1987-88 was multiplied by the GDP deflator of $.97 .{ }^{25}$ Then this amount was multiplied by the previous year's deflator in order to arrive at the previous fiscal year's estimate, and so on, until FY 1983-84. As with other tables, the estimates for the first three fiscal years were lowered by dividing the estimates by 7. Again, this was done to reflect the small size of the EZ during its first 3 years.

As can be seen, the amount of revenues and fees lost due to this incentive have not been very large when compared to the costs of other incentives. In fact, in an interview with Paul Nicholson of the Louisville and Jefferson County Department of Inspections, Permits and Licenses, very few certified firms within the EZ take advantage of this incentive. He could not speculate as to why this was so (interview, June, 1996). The estimated total amount of fees foregone, $\$ 569,199.08$, also seems consistent with Nicholson's estimate that $\mathrm{EZ}$ incentives have cost the Department of Inspections, Permits, and Licenses anywhere from $\$ 40,000$ to $\$ 50,000$ per year on average.

Table 46 takes information from the previous tables in this chapter as well as other data and gives the total

${ }^{25}$ When calculating back in time, numbers for years after the base year have to be divided by GDP deflator numbers. After the base year is reached, estimates are then multiplied by GDP deflator numbers that are less than 1.00 in order to discount values. 
estimated costs associated with EZ economic development. The accuracy of such estimates are questionable because of a lack of data and cooperation provided by state and local officials. However, these figures represent the best estimates possible based upon records available.

Before going further, some of the amounts in Table 46 need elaboration. By looking at City of Louisville budget documents, it was estimated that $\$ 532,725$ had been spent on

\section{TABLE 46}

Estimated Total Enterprise zone Costs, 1983-96

Expenditures and/or Revenues Foregone

Administration and Overhead

Economic Development Bonds

Inspection, Permit and License Fees foregone

Sales Taxes lost due to exemptions on the purchase of building materials, equipment, and machinery

Motor Vehicle Usage Taxes foregone

Net operating Loss Carryforward

Taxes lost due to Capital Gains exemptions

Taxes Foregone on exempted interest income earned from loans to other businesses in the $\mathrm{EZ}$ Tax credits for hiring disadvantaged workers

TOTAL

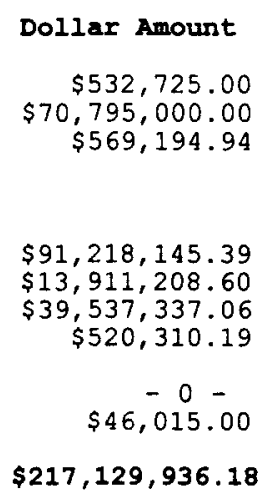

$\$ 217,129,936.18$

administration and overhead for the EZ. This is a very low amount given the size of the zone, but it is a reasonable estimate because the staffing of the Louisville Ez program has mostly consisted of just two people over the past 14 years. Such a small staff probably accounts for the lack of recordkeeping and attention to detail that was necessary to adequately monitor the Ez program.

The category Taxes foregone on exempted interest income earned from loans to other businesses in the $\mathrm{EZ}$ shows a zero amount because, according to all records reviewed, this incentive never was used. Apparently, there was no lending of 171 
money from one Ez firm to another.

Finally, the amount of $\$ 46,015$ for Tax Credits for

hiring disadvantaged workers came directly from Kentucky

Revenue Cabinet reports. This incentive was started in July, 1992, and was intended for the EZ program to put a greater emphasis on job creation for the long-term unemployed or for those who had been on some type of public welfare for at least 90 days. Despite the fact that the original 1982 legislation was supposed to help such workers, a specific incentive to hire such workers was not implemented until 10 years later. This incentive consists of a $\$ 1,500$ tax credit per disadvantaged worker hired. This tax credit can be taken at any time within a 5 year period after the worker is hired. The amount $\$ 217,129,936.18$ was estimated to be the total costs of EZ economic development incentives. One could question whether the amount for economic development bonds should be included in this list because capital expenditures via bonds are not called for in the EZ enabling legislation. However, to ignore the effects of these economic development bonds would be to ignore the effects of job creation and retention through government expenditure policies. One must control for the impact of these expenditures. Therefore, it was decided to include the face value of the bonds as an EZ cost. 26

26 In looking at municipal budgets showing bond issues and expenditures by the City of Louisville and Jefferson County during this same time period, I could find no evidence of either of the two governments issuing debt or spending money for local economic development projects. Instead, both 
If, according to OED estimates, approximately 18,000 new jobs were created due to EZ incentives (Shafer, 1996); and if around 24,000 jobs were retained due to the EZ from 1983 to 1990 (1990 OED Press Release); and if 21,193 jobs were retained due to $\mathrm{EZ}$ incentives from 1989 to 1994 (1995 OED Press Release), then getting a firm number for the total number of new jobs created as well as jobs saved from these sources is problematic.

Table 47 shows that if one totals up all the new jobs created according to OED Annual Reports from 1983 to 1996, then that number is 19,664 , not 18,000 . Also, OED has never clarified how much overlap there exists between the number of jobs saved between 1983 and 1990 (24,000) and the number of jobs saved between 1989 and 1994 (21,193). However, OED's 1995 Press Release did claim that the total number of jobs created and/or saved was 32,981 from 1989 to 1994 (1995 OED Press Release, p. 2). This figure was composed of 11,788 jobs created and 21,193 jobs saved. If one were to add 6,212 jobs to the 11,788 jobs cited, this would bring the total amount of jobs created to the 18,000 cited in a Courier Journal article (Shafer, 1996). Adding 6,212 to 32,981 to bring the total number of jobs created and/or saved due to EZ incentives to 39,193. This would also mean that the costs per job created and/or saved would be roughly $\$ 5,540(=\$ 217,129,936.18 / 39,193)$. Is this cost too high or too low? The best way to gauge this is to compare it to the benefits per job created and/or saved. 


\section{EZ Program Benefits}

Table 47 provides an estimate of the possible tax revenues generated by new jobs created by $\mathrm{EZ}$ incentives. As pointed out in an earlier chapter, OED claims that roughly 18,000 jobs were created due to the EZ program. However, Table 47 shows that when one uses OED annual reports and sums the number of reported jobs created in each of those annual reports, the number of new jobs is 19,664. Nevertheless, I will use the 19,664 number in order to estimate Ez financial

TABLE 47

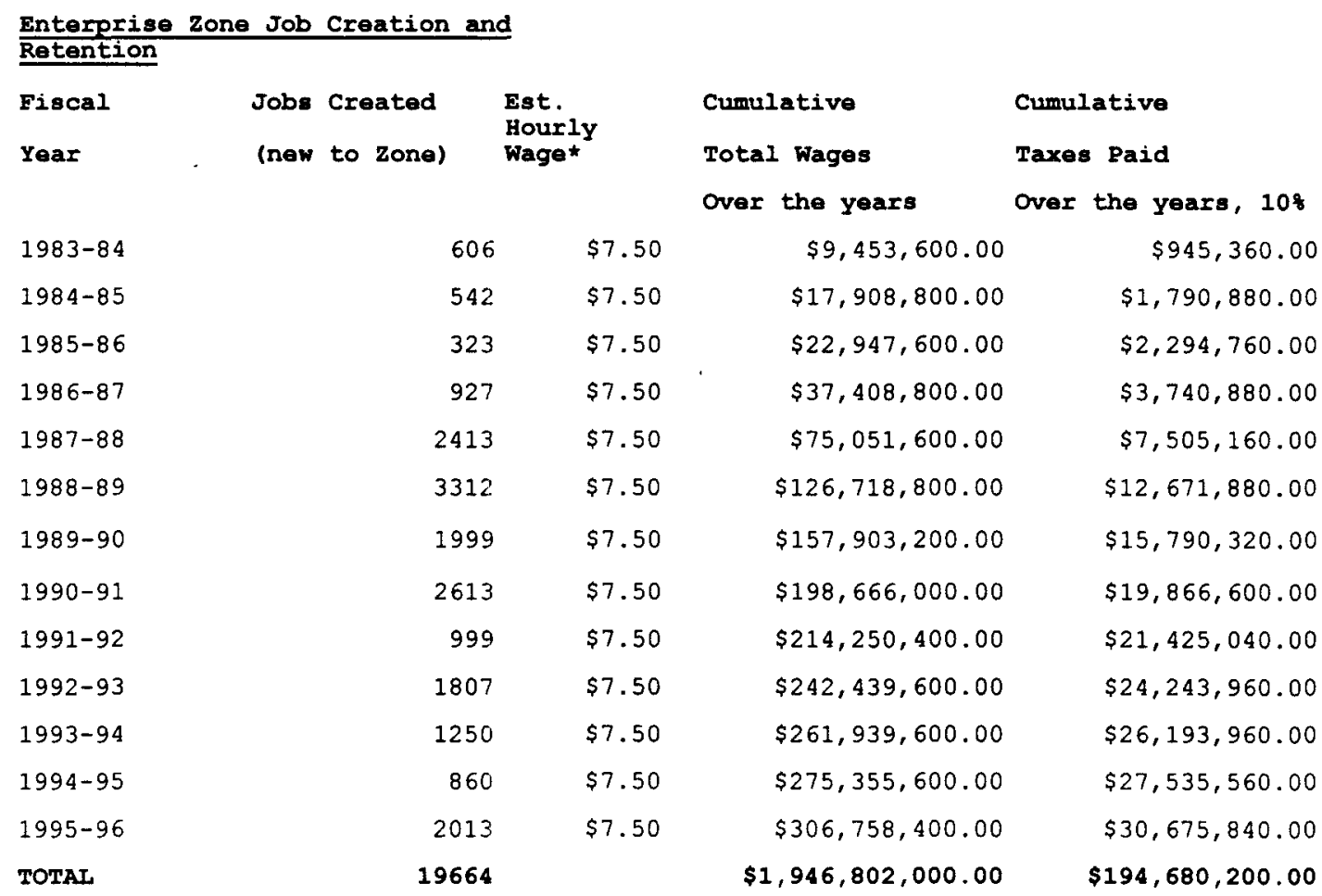

public housing, roads, parks, etc. 174 
TABLE 47 ,

CONTINUED.

Cumulative

Total Wages

(jobs saved)

Fiscal Year

1983-84

1984-85

1985-86

1986-87

1987-88

1988-89

1989-90

1990-91

1991-92

1992-93

1993-94

1994-95

1995-96

TOTAL

Jobs
Retained*
0
0
0
0
11646
0
6003
0
0
1653
0
282
528
20112

Cumulative

Taxes paid from

jobs saved

(estimated 10\%)

$\$ 0.00$

$\$ 0.00$

$\$ 0.00$

$\$ 0.00$

$\$ 181,677,600.00$

$\$ 181,677,600.00$

$\$ 275,324,400.00$

$\$ 275,324,400.00$

$\$ 275,324,400.00$

$\$ 301,111,200.00$

$\$ 301,111,200.00$

$\$ 305,510,400.00$

$\$ 313,747,200.00$

$\$ 2,410,808,400.00$
Cumulative Total

Taxes paid from

jobs saved and

created.

$\$ 945,360.00$

$\$ 1,790,880.00$

$\$ 2,294,760.00$

$\$ 3,740,880.00$

$\$ 25,672,920.00$

$\$ 30,839,640.00$

$\$ 43,322,760.00$

$\$ 47,399,040.00$

$\$ 48,957,480.00$

$\$ 54,355,080.00$

$\$ 56,305,080.00$

$\$ 58,086,600.00$

$\$ 62,050,560.00$

$\$ 435,761,040.00$

*Assumes $\$ 7.50 /$ hour because 1995 OED report stated that this was avg. wage across all industries. KY. Revenue Cabinet reported that avg. hourly wage for FY 93-94 and FY 94-95 were only $\$ 7.63$ and $\$ 8.00$, respectively.

* *These are the only years for which oED gave numbers for jobs

retained. The TOTAL number, however, is close to a 1990 OED report

which claims that between 1983 and $1990, \mathrm{EZ}$ incentives had helped to

retain 24,000 jobs. In 1995 , OED issued a report claiming that the $\mathrm{Ez}$

had helped to save around 21,000 between 1989 and 1994 . However,

neither of these two reports listed jobs retained by fiscal year.

Source: Louisville and Jefferson Co. Office for Economic Development (OED) .

benefits. 27

Table 47 assumes that each job created was full-time, year-round, and paid $\$ 7: 50$ per hour. OED claims that on average $E Z$ wages are $\$ 7.50$ per hour, although the presence in the Ez of some high paying firms such as Ford Motor Company may skew this number upward. OED also claims that all of the

27 The discrepancy between the two numbers is probably due to either some firms being de-certified between the time of the last OED annual report and the time of OED spokesperson Pettison's proclamation that the EZ should be credited with creating 18,000 jobs or due to revisions made for previous years. 
jobs it counts are full-time and year-round (interview with Paul MCGowan of OED, 9/96). According to surveys of firms by USI, it is estimated that around $95 \%$ of all their workers are full-time. The surveys did not ask about average pay. Therefore, OED claims were used to obtain the estimates in Table 47 .

Making generous assumptions based upon the information above (that is, that each worker worked 40 hours per week, 52 weeks per year, and earned $\$ 7.50$ per hour) this means that the typical EZ worker earned \$15,600 per year from 1983 to 1996. According to Coomes and Kornstein (1996, p.28), these annual earnings are far below what typical Louisville metro area nonmanufacturing and manufacturing jobs paid in 1993: approximately $\$ 23,000$ for non-manufacturing and roughly $\$ 38,000$ for manufacturing. Even though OED may claim that EZ incentives helped to create around 18,000 new jobs, the quality of pay for these new jobs may be debatable when compared to how well others are paid throughout the metropolitan area. In fact, by today's standards, one who earns $\$ 15,600$ per year would be living at or below the poverty line if he or she had any non-working dependents.

The typical EZ worker like all workers in Jefferson County would have to pay city, county, and Jefferson County Public School occupational taxes of $2.2 \%$. Such a person would also probably be in Kentucky's lowest income tax bracket of $4 \%$ and would qualify for the state's low income tax credit. Kentucky state sales taxes of 6 cents on the dollar would also 
hit this person hard. However, if one assumes that a person at this income level spends a large portion of his or her budget on food, then the sales tax burden is probably not as onerous since food is not taxed. With all this in mind, Table 47 assumes that each person employed due to EZ incentives paid to the state and local governments approximately 10 of of his or her income in taxes.

In cumulative terms, Table 47 shows that given jobs created and retained, state and local governments should have received $\$ 435,761,040$ in taxes from EZ workers from 1983 to 1996. Taking this amount and dividing by the estimated number of jobs created and/or retained, one obtains a benefit per job of around $\$ 11,118$. This is a little more than double the amount calculated for the cost per job created and/or retained- $-\$ 5,540$. On the basis of this cost per job to benefit per job comparison, one could conclude that the EZ program was a success. Benefits appear to outweigh costs by over two to one. The program appears cost-effective using this simple criteria.

Table 48 shows the amount of private capital investment that OED claims that EZ incentives helped to attract (1983 to 1996 OED Annual Reports). The dollar amounts suggest an extraordinary amount of business investment in the EZ from 1983 to 1996. If one were to compute EZ costs per dollar of investment, then only $\$ 0.14(=\$ 217,129,936.18 / \$ 1,545,248,477)$ was spent or foregone in tax revenues due to EZ incentives in order to attract this volume of capital. This is a very small 
amount.

If all of this capital investment resulted in net job creation (i.e., more jobs were created by capital than replaced or supplanted by capital investment), and if all of this investment helped increased the profitability of EZ firms, then the state would have received even more taxes paid on business profits and wages than if $\mathrm{EZ}$ incentives had not been in place. There exists no data to either support or refute this claim. However, if business tax receipts were increased, then the EZ benefits in Table 47 would be even larger in dollar value. Also, if any of this investment was taxable property, then property tax receipts would also be expected to rise, thereby boosting the total amount of $\mathrm{EZ}$ benefits in dollar terms.

\section{TABLE 48}

\section{Private Capital Investment}

$\begin{array}{lr}\text { Fiscal Year } & \text { Dollar Amounts } \\ 1983-84 & \$ 9,250,000.00 \\ 1984-85 & \$ 13,840,000.00 \\ 1985-86 & \$ 3,830,000.00 \\ 1986-87 & \$ 66,730,000.00 \\ 1987-88 & \$ 432,000,000.00 \\ 1988-89 & \$ 185,640,000.00 \\ 1989-90 & \$ 273,400,000.00 \\ 1990-91 & \$ 190,585,652.00 \\ 1991-92 & \$ 63,499,000.00 \\ 1992-93 & \$ 91,921,132.00 \\ 1993-94 & \$ 68,800,000.00 \\ 1994-95 & \$ 38,556,087.00 \\ 1995-96 & \$ 107,196,606.00 \\ \text { TOTAI } & \$ 1,545,248,477.00 \\ \text { SOURCE: Louisville } & \text { and Jefferson County office for Economic Development Annual }\end{array}$


It should be noted that the greatest portion of private capital investment listed in Table 48 occurred through EYs 1987-88 to 1990-91. This time period roughly corresponds to the time period when Louisville's airport was undergoing a massive expansion. Along with this expansion, UPS expanded its operating facilities on the airport's premises. This may account for the large dollar amounts of private capital investment during this time period. If so, it would seem that the airport received a disproportionate amount of both private and public investment dollars relative to the EZ. ${ }^{28}$

\section{Caveats on EZ Job Creation and Retention as well as EZ Capital Investment}

The preceding cost-benefit analysis can be criticized on several grounds. In a survey done by USI during the summer of 1996, around $67 \%$ of all EZ certified firms were interviewed regarding $\mathrm{EZ}$ incentives and the usefulness of these incentives to the firms. Table 49 gives a brief synopsis of survey findings. As mentioned at the close of Chapter 7, when it came to hiring practices, survey respondents indicated that incentives had only directly helped to create 5,760 new jobs. Also, respondents credited the EZ incentives with "saving" just 3,152 jobs and creating or saving 6,333 jobs. Without regard to incentives, the 851 firms interviewed indicated that their workforce had grown by a net of 13,271 employees since the companies had acquired EZ certification. To repeat a

28 Unfortunately, OED does not keep summary records of where 179 
caveat from Chapter 7 , it should be remembered that not all firms interviewed had been certified at the time that the zone had come into existence. Some companies had been certified since mid-1983 whereas others had only been certified for a couple of years.

With regard to capital investment, on average $77 \%$ of the firms interviewed said that they would have undertaken capital investment regardless of EZ incentives. Therefore, some

Table 49

USI Survey Results of $851 \mathrm{Ez}$ certified firms*

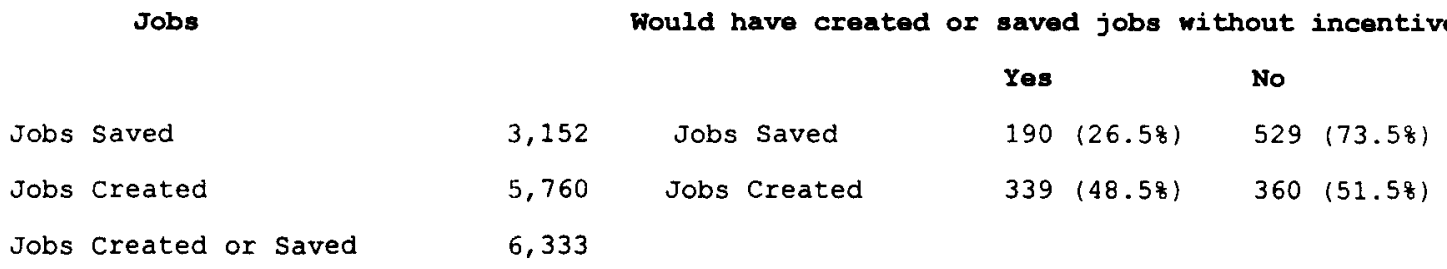

Investmant

New or used equipment

Motor Vehicles

Construction and Buildings
Would have done investment anyway?

$\begin{array}{lllll} & \text { Yes } & \text { No } & \\ 569 & (818) & 137 & (198) \\ 393 & (778) & 116 & (238) \\ & 389 & (75 \%) & 132 & (258) \\ & 1,351 & (778) & 385 & (238) \\ \begin{array}{l}\text { Total and Average } \\ \text { of "Yes" and "No' } \\ \text { Answers }\end{array} & & & & \end{array}$

\$Note: Survey number do not always add to 842 because not all firms interviewed used all incentives available.

portion of the $\$ 1.5$ billion in investment in Table 48 might have been carried out any way. However, it is possible that the average of $23 \%$ of the respondents who said that one or more incentives made a difference in investment decisions may 
have made the bulk of the $\$ 1.5$ billion in investment. There is no way to know for sure how much of this investment is due to what portion of the EZ certified firms. But, just as with business location, Schmenner (1981), Blair (1995) and others point out that tax considerations are only one of many considerations in capital investment decisions. Investment decisions are generally made with regard to future expectations about long-term firm profitability, adequate financing, changes in technology, etc. As mentioned previously, United Parcel Service (UPS) was not interviewed. If one adds UPS's 14,000 jobs to the 13,271 jobs that respondents reported, this would greatly boost the number of jobs created within the EZ without regard to incentives. However, it should be remembered that more than half of UPS's positions are part-time. Also, probably not all UPS employees live within the EZ. If these jobs have been counted by OED as jobs created and/or retained within the $\mathrm{EZ}$, then the benefits suggested by Table 47 would be significantly diminished.

The USI survey also suggests other problems with Table 47. Table 49 shows that only $26.5 \%$ of the survey's respondents said that the $\mathrm{EZ}$ incentives had helped to save jobs, and just $48.5 \%$ said that EZ incentives had helped to create new jobs. If these percentages are reflective of the over 1,200 Ez certified firms, then the benefits indicated in Table 47 could be further diluted. That is, a good portion of the number of jobs created and/or saved could be overstated. Respondents indicated that $\mathrm{EZ}$ incentives were responsible for 
creating and/or saving 6,333 jobs. These firms apparently created only a third of the 18,000 new jobs created. Without interviewing the other 400 or more EZ certified firms, there is no way to know whether there could be more jobs to add to the 6,333 job figure.

Next, there is the problem in survey research of respondents often not being candid in their answers to questions no matter how hard the researcher tries to control for this possibility. There could be a portion of respondents le.g., a portion of the $48.5 \%$ of those firms interviewed who said that incentives had made a difference in hiring new workers) who intentionally overstated the EZ program's impact out of their fear of possibly losing Ez tax benefits. If this is true, then claims regarding $\mathrm{EZ}$ job creation and retention as well as capital investment could be further deflated. Additionally, some of the assumptions made in Table 47 may have been far too generous. To assume that all the jobs created were full-time and year-round is probably an overstatement, especially because of UPS's presence in the EZ. Also, even if the jobs mentioned in Table 47 were year-round and full-time, the amount of taxes paid by the typical worker earning the average $\$ 15,600$ salary may be overstated. If a taxpayer can itemize deductions, then occupational taxes and other local payroll taxes withheld are deductible from one's state income tax. If many of these workers were able to itemize, then the amount that they would have paid in state income taxes would have been reduced. More importantly, if 
most of these workers had dependents or any other forms of deductions, their tax liability would have been reduced substantially. In fact, if one considers all of the possible deductions, exemptions and tax credits available to such lowincome taxpayers, then many of these workers may have received from the state a complete or nearly complete tax refund on all taxes withheld during the year. This possibility would also greatly reduce the amount of benefits, in terms of taxes paid to the state, due to the Ez program.

In fairness to the EZ program, it could be argued that, even if EZ benefits are overstated in Table 47, creating and saving jobs probably prevented many workers from having to rely upon social welfare programs which may have cost the state more than the costs associated with the EZ program. However, given the average low pay of the EZ jobs, the EZ program cannot exactly claim to have moved many people into the ranks of the middle class. Instead, the average salary of $\$ 15,600$ per year would generally be considered a pay level for the working poor. Certainly this would not have been enough to help those in the original Ez neighborhoods for whom KRS

\subsection{5 was originally intended.}

More importantly, recall Tables 10 and 13 regarding the original EZ, and Tables 16 and 19 regarding the full-size EZ. Using Coomes and Price data, Table 10 showed a decline in the number of jobs in the original EZ between 1980 and 1990 . Table 13, using CBP zip code level data, also showed a decline between 1981 and 1994 for the same area. For the full-size 
EZ, Table 16, based on Coomes and Price data, showed a small decline in employment from 1980 to 1990 whereas Table 19 using CBP data showed a small increase in employment from 1981 to 1994. Considering the data in these four tables, one can only conclude that jobs created by EZ incentives were jobs that merely offset job losses within the full-size Ez. The original Ez did not even do that well. Ironically, it was the original Ez that most closely resembled the type of areas targeted for EZ incentives in KRS 154.45 .

The tables in Chapter 5 also question the benefits indicated in Tables 47 and 48 . Those tables showed all EZ communities losing population and workers. Was a sizable portion of the new jobs created and/or saved in the Ez given to residents outside of the EZ? Was any new business investment undertaken in the Ez barely enough to offset disinvestment within the EZ? These tables raise that possibility. If this is true, then several of the original goals of KRS 154.45 were not met regardless of how one weighs program costs and benefits.

Additionally, the tables in chapters 5,6 and 7 indicate that not one segment of the $\mathrm{EZ}$ grew at rates comparable to the control areas. Even if program benefits did outweigh program costs, EZ growth and quality of life did not match growth and quality of life in areas that did not receive the same economic development stimulus. One must then question what factors led these others areas to grow faster than the EZ despite these areas not receiving $\mathrm{EZ}$ incentives. Could the 
over $\$ 217$ million in incentives have been better spent? I will have more to say on this in the next chapter.

Finally, it should be pointed out that federal dollars used to expand and rebuild Louisville's airport were not included in the costs of the EZ program. However, one could argue that, just as with state funds, these costs should be taken into account since these funds were used in an area that was part of the EZ. Just as with state expenditures, federal expenditures probably provided an economic stimulus to the airport area that EZ incentives could not match. According to a March 23, 1997 Courier-Journal article, total costs for the expansion and enhancement of the airport will probably total $\$ 676$ million when the project is completed (Howington, 1997). This is more than double the original projected costs that were forecasted in 1988. According to the article, many construction expenditures have gone over budget in order to accommodate UPS and neighborhoods affected by UPS and airport operations. The Kentucky Air National Guard base headquarters had to be moved from one part of the airport grounds to another; and a greater number of area residents had to be removed and relocated than was originally anticipated. All of this was done because of increased traffic volume due to a second runway and more UPS shipping flights (Howington, 1997). To be fair to UPS, the article noted that UPS had contributed $\$ 54$ million to airport expansion and renovation. Also, according to state and local officials, the airport expansion has generated around $\$ 85$ million a year in economic 
benefits, including state and local taxes. It is also pointed out in the article that UPS's growth has helped Louisville and Jefferson County attract businesses that rely upon UPS's fast shipping abilities. However, if one adds several hundred million dollars in federal aid to the list of $\mathrm{EZ}$ costs in Table 46, then $\mathrm{EZ}$ costs of job creation would at least equal if not exceed EZ job creation benefits (Table 47). These additional dollars would also greatly increase the ratio of $\mathrm{EZ}$ costs to private capital investment as well. Perhaps the ratio would rise from fourteen cents on the dollar to nearly 50 cents on the dollar.

For example, adding an additional $\$ 600$ million $^{29}$ to the total costs of Table 46 of roughly $\$ 217$ million brings total EZ costs up to approximately $\$ 817$ million. Dividing this number by the estimated 39,193 jobs saved and created yields a cost of $\$ 20,846$ per job created and saved. This is approximately $\$ 9,000$ more than the benefit per job saved or created that was calculated above. Also, this means that the cost of each job saved and/or created was greater than what the typical job in the Ez annually paid: $\$ 15,600$. Clearly, this outcome would not indicate a good return on either federal or state taxpayers dollars.

29 Recall that $\$ 60.5$ million in state bonds have been accounted for in Table 46 . Adding $\$ 600$ million to the total derived in Table 46 would still leave out approximately $\$ 16$ million of the projected total airport costs of $\$ 676$ million. This has been done so as to be cautious in estimating the final costs of airport expansion. 


\section{The EZ and Disadvantaged Workers}

Table 46 showed that between FYs 1992-93 and 1995-96, only $\$ 46,015$ in tax credits for hiring disadvantaged workers had been claimed by EZ companies. EZ certified firms can receive a tax credit of $10 \%$ of a disadvantaged worker's annual salary, up to $\$ 1,500$, for each disadvantaged worker hired and can carry forward such credits for up to five years. A tax credit is more desirable than a tax deduction because tax credits can be taken directly off tax bills whereas a deduction simply lowers a firm's gross income before taxes are assessed.

In KRS 154.45, one of the three possible conditions of becoming an EZ certified firm was to have at least $25 \%$ of a firm's workforce consist of workers who were previously categorized as "disadvantaged" (see Chapter 3 for definition). The 1992 General Assembly did not consider this adequate, so it amended KRS 154.45 to provide businesses with direct tax credits for hiring disadvantaged workers (KRS 154.45, p. 421).

Whether this change in the law worked is either questionable or unknown. If the maximum of $\$ 1,500$ per worker is used, then the amount of $\$ 46,015$ indicates that only about 30 workers have been hired over the previous four fiscal years under this provision of the law. Either that is the case, or many firms have not yet claimed credits for disadvantaged workers that they have hired. Or, they have only claimed a portion of the credits. Businesses do have up to five years 
to take the full tax credit.

Another possibility is that since this provision of the EZ law is relatively new, perhaps many firms are not yet aware of it. If this is true, then it would indicate that OED has done a poor job of promoting this EZ incentive. On the other hand, perhaps many firms are not interested in hiring these types of workers because they have a lack of work experience or skills. If that is the case, then these tax credits would only be used by low-skill, low-wage employers. Using this logic, the small amount of $\$ 46,015$ would possibly indicate that many of these low-skilled, disadvantaged workers are not being hired. Ironically, these are the very people for whom Ez incentives are supposed to help.

In any event, this incentive may see greater usage over the next few years, but for now it does not seem to be working that well, especially for residents of the original EZ. Previous chapters have shown very little progress made in alleviating poverty and unemployment in this area. Creating job opportunities for residents in the original EZ also seems to have been an unfulfilled goal of KRS 154.45. Instead, the tables in Chapter 5 show this area to still be an area of urban poverty. The $\$ 46,015$ in tax credits given for hiring disadvantaged workers may have been better used for something else, such as training people with low job skill levels in order to make them more employable. 


\section{Summary}

The results of $\mathrm{EZ}$ cost-effectiveness analysis done by comparing benefits per job to costs per job, and costs per capital investment must be interpreted cautiously. The caveats mentioned above dilute OED arguments of total EZ success. Most of all, the people for whom the program was supposed to benefit the most--disadvantaged workers--seem to have benefited very little if at all from EZ program initiatives. Also, as pointed out in previous chapters and in this chapter, the area that was originally targeted for EZ incentives and the most hard-pressed for neighborhood revitalization and job creation has shown the least amount of improvement in its social and economic climate.

This especially diminishes OED claims of complete EZ success when one considers what has happened in the control community of Newburg. Although similar in social and economic conditions, Newburg, without EZ incentives, at least was stable during the same time period as the original EZ was still undergoing decline.

The next and final chapter summarizes the findings of all previous chapters and the implications that these findings have for future policy consideration. A thorough critique of EZ program efficacy will be given. It will be shown that the EZ program had many shortcomings because of its failure to plan for and remain focused on its original goals: solving urban blight, poverty and outward migration. 


\section{CHAPTER IX}

\section{Review of Findings: Implications for Research, Theory, and Public Policy}

\section{Summary of Findings}

The preceding chapters have made the case that Louisville and Jefferson County's Enterprise Zone (EZ) cannot be considered a total success. EZ proponents can claim mixed results overall, but results vary widely according to which parts of the EZ are examined and according to the financial conclusions one draws about the cost-effectiveness of the entire program.

The Original EZ

Through the use of Census Data, HMDA data, and PVA data, the analysis showed that the original EZ continued to suffer from poverty, poor housing conditions, outward migration and low property values, as well as sluggish lending activity, despite EZ incentives. The original EZ did show an increase in educational levels and overall household earnings, but these levels were still lower than those of the control area. A shift-share analysis using two different data bases, showed poor job creation performance in the original EZ. To the chagrin of EZ proponents, the community juxtaposed to the original EZ for comparison purposes (Newburg) did quite well in the shift-share analysis presented in Chapter 7 when 
compared to the original EZ. It also faired better than the original EZ despite receiving no economic development assistance.

The outcome measurements showed the original EZ losing residents and jobs whereas a similar area, Newburg, roughly retained its original level of residents and jobs. This was true no matter which time period was used to examine the two areas. What is especially noteworthy is that the Newburg area received no type of economic development stimulus and/or program assistance during any of the time periods considered. Either a single factor or a combination of factors could explain Newburg's stability and the original Ez's stagnation. One can speculate that, even though in 1980 Newburg was roughly similar to the original EZ with regard to social, economic and demographic characteristics, there were events taking place in the original $\mathrm{Ez}$ which made it a less desirable place in which to live, work, and invest, in comparison to Newburg. A higher crime rate and/or a higher level of environmental problems (e.g., brownfields) in the original EZ when compared to Newburg would surely make the original Ez less attractive. Until a locality can solve its problems of high crime and environmental pollution, no amount of tax incentives can generate neighborhood business and job development. Tax incentives alone probably cannot make up for the risks that business firms would incur if they located in a crime-ridden and environmentally hazardous area.

Another possible explanation, which is tied to the 
previous one, is that despite the pre-Enterprise zone program similarities between Newburg and the original EZ, there were and still are problems in the original EZ that only large amounts of government spending, along with tax incentives for businesses, could have solved.

When one looks at KRS 154.45 and the original 3.75 square mile area targeted for EZ program assistance, then the program did not appear to assist those in this impoverished and blighted area to the extent desired in the enabling legislation. This would be a narrow interpretation of the EZ program's efficacy, but it is justified because the original goals and objectives of Kentucky's EZ legislation were intended for economically depressed, urban areas.

\section{Areas outside of the Original EZ and the Full-size EZ}

Looking at the tables in Chapter 5, the full-size EZ showed modest gains in many social and economic conditions, but it still lagged behind the rest of Jefferson County and the Jefferson County as a whole. In the full-size Ez, job generation was at least static, showing no big losses or gains. The exception within the full-size EZ was the airport area. This area showed robust job growth, although as pointed out in other chapters, this job growth may not have occurred solely due to Ez incentives. Finally, Bluegrass Industrial Park also did at least as well as Louisville's airport, and yet Bluegrass received no economic development aid. It appears that the $\mathrm{EZ}$ incentives may have worked to 
some degree in EZ areas outside of the original EZ and the airport. In these areas, it could be claimed that EZ incentives may have played a small but important role in keeping lower middle income areas from sliding into lower class status. Although there is no direct proof, EZ incentives may have helped these areas "hold their own" socially and economically by keeping viable such areas as Rubbertown, Riverport, and the Strawberry Lane industrial area. If this is the case, then perhaps $\mathrm{EZ}$ incentives work best in areas which are neither impoverished or wealthy. Perhaps EZ incentives work best in areas which are on the verge of economic decline, but are above the very lowest levels of poverty and economic deprivation.

When it comes to Louisville's airport, EZ incentives probably only played a very minor and perhaps unimportant role. Instead, it appears that the nearly $\$ 676$ million that has been and/or will be invested in this area has been a major catalyst for job creation. Without building a second runway and new facilities as well as removing several nearby neighborhoods, UPS would not have expanded its operations in Louisville. In fact, the company probably would have relocated to another airport. While UPS has become Jefferson County's largest employer, it must be remembered that most of its nearly 14,000 workers are part-time and earn $\$ 8.00$ per hour (Howington, 1997). 
Cost-Effectiveness

The EZ program, whether small in size or large, appeared to be a financially cost-effective program over the years when one uses the only real data kept by an agency since the EZ began. Using OED data, and the most cautious assumptions possible, EZ incentives may not have helped firms to create and retain, on average, the best-paying jobs in the metro area, but at least the costs of job creation was outweighed by job benefits. Nevertheless, the caveats introduced cast some reasonable doubts about the cost-effectiveness of the EZ program, especially when one introduces what possible effects that federal and state spending had on creating jobs in the Louisville airport area.

Summarizing the research findings, it appears that local economic development officials cannot make the claim that the Ez program was completely and absolutely successful. At best, the evidence shows that job growth in the full-size EZ, with the exception of the airport area, was stagnant during the time periods covered in the analysis. The evidence suggests that local officials can only claim that their estimate of 18,000 new jobs created is a gross number and not a net figure. The same is true for their claim that the EZ incentives retained around 24,000 jobs. Finally, the evidence also strongly suggests that EZ incentives cannot take full credit for airport job growth. There is little doubt that federal and state public investment played a major role, if not perhaps the biggest role, in airport job growth. 
The evidence and arguments presented in this study also suggest that the original EZ probably saw further decline, despite $\mathrm{EZ}$ incentives, for another major reason besides those mentioned above. By expanding the Ez beyond a geographically limited area, the EZ program probably lost its focus as an urban, anti-poverty program and instead became a catch-all economic development program for most of the City of Louisville and for parts of Jefferson County. When interviewed by a Wall street Journal reporter, EZ proponent and theorist stuart Butler was dismayed at how large Louisville's EZ had become since its beginning (Davidson, 1992). Butler said that EZs were never meant to encompass such large geographic areas because to do so would cause an EZ program to lose its urban emphasis. Within just a few years of its inception, Louisville's EZ program completely changed direction without any mandate from state government and without any consideration given to the residents of the original EZ. According to the Wall street Journal article, the EZ was allowed to expand by Kentucky's Enterprise Zone Authority without much deliberation or planning, if any, with regard to the consequences of such action. The EZ was allowed to expand so as to include UPS and Louisville's airport, as well as to make possible the City-County Compact signed in 1986. It appears that the goals and objectives of KRS 154.45 were conveniently overlooked or glossed over in order to pursue other goals and objectives unrelated to urban poverty or blight. 
As indicated in Chapter 3, there never was any real monitoring of EZ program performance until 1992. Adequate planning and program assessment cannot be done without monitoring program outcomes (Rossi and Freeman, 1983; Schofield, 1987). And with regard to program outcomes, the broad goals and objectives of KRS 154.45 were never sufficiently monitored at the local level in order to accurately measure program results. Had local economic development officials identified specific goals to be achieved in the original EZ, perhaps this area's needs would not have become overlooked in the various expansions that occurred after 1983. A specific goal for the original Ez area, for example, might have been to reduce its unemployment by onehalf over the zone's 20 year life span. But nothing so explicit was ever established with regard to the original EZ. The abandonment of the original EZ appears to have been a failure in planning. In this regard, this dissertation confirms much of what Rubin and wilder (1996) found in their studies of EZs throughout the U. S. There are few solid conclusions about the efficacy of many EZs throughout the $U$. S. because so many of them failed to specify program goals and objectives when they were started. Many programs were conceived with little planning, and very little attention was given to monitoring program outcomes, if any outcomes were specified by programs. This is why there appears to be, paraphrasing Rubin and Wilder, a gap between the EZ rhetoric of accomplishments and the Ez reality of accomplishments. 


\section{Contributions of the Research to Economic Development Theory and Public Policy}

\section{Limitations of this Study and Methodological Caveats}

Before making any further policy observations and recommendations, it should be stressed that there were many gaps in the data used in this study. Due to the lack of monitoring of the EZ program by the Commonwealth of Kentucky, many estimates and assumptions had to be made in the costbenefit analysis appearing in Chapter 8. At all times, however, estimates were made cautiously by giving OED the benefit of the doubt, and using their data alone, estimates of E2 program costs and benefits look very good. However, in order to give balance to the analysis, caveats and other considerations were included in Chapter 8 to give the reader a better perspective on the costs and benefits of the EZ program. Based on the evidence in Chapter 8 , it appears that the EZ program was not nearly as cost-effective as one would initially conclude using only OED numbers and data.

Likewise, the shift-share method and data used in Chapters 6 and 7 is not without limitations. As stated before, shift-share analysis cannot explain why an area may have a competitive advantage or disadvantage relative to another area. The number of jobs calculated for "S" (the local share effect) is also only a residual number that is left after county and industry-specific job forecasts are subtracted from the actual number of jobs gained in an area over a specific time period. Just because " $S$ " may be a 
positive number does not guarantee that an area has a competitive advantage relative to another. Random chance, luck, or the selection of a certain beginning and ending year (like 1981 and 1994), may play a role in " $S$ " yielding a certain value. The choice of two other years used in a shiftshare analysis comparing two regions could yield different results than two other years chosen. A researcher is not always in a position to explain why or under what économic circumstances " $S$ " indicates some type of possible competitive advantage or disadvantage that an area may have relative to another.

Additionally with regard to the analysis presented in Chapters 6 and 7, there is the problem of arbitrarily dividing zip codes either in half, or by some fraction in order to arrive at job estimates within certain areas of Jefferson County. The weakness of doing this is the implicit assumption that business firms are evenly and uniformly spread out over a given area. This, of course, is not generally true. Again, this was a crude, yet necessary method, and has been used in other studies.

Finally, the Census data used in Chapter 5 deserve a word of caution. The data appearing in Tables 1 to 6 represent only two years: 1980 and 1990. If data for each year from 1980 to 1990 had been available, it is possible that the results of 1990 Census data may have been misleading. That is, for example, perhaps the original EZ was actually doing quite well up through and including 1989, and then 
things took a turn for a worse. Although very improbable, this is always possible when comparing cross-sectional data at two different points in time, especially over a ten year period.

Nevertheless, the methods used in this study were basically sound and the best ones available. The fact that shift-share analysis using two different data bases and two different points in time (1980 to 1990 versus 1981 to 1994) showed pretty much the same trends lend credence to the idea that one can assume an area has a competitive advantage or disadvantage relative to another. Also, the other data sources and methods generally showed the same trends. Through using various analytic methods, there was direct and indirect confirmation of the conclusions made in this study. More importantly, the multiple methods and data sources showed consistent patterns and trends, thus reinforcing the conclusions reached.

I would argue that the support garnered for the conclusions of this dissertation through a multi-method approach make this study a unique contribution to the study and evaluation of enterprise zones. This characteristic, along with the comprehensive nature of the study, make it different from others conducted so far. The literature on EZs mostly show just one method applied in an EZ evaluation in order to assess one outcome-either job creation, investment, or some other objective. This dissertation has looked at every possible aspect of the Louisville EZ and has tried to 
judge its efficacy by using more than one method and one outcome measurement. The findings and methods used improve both our understanding of EZs and how to study them.

\section{Policy Implications and Problems}

Since the Louisville and Jefferson County EZ program was and probably still is a program without a clear focus, and since its performance has been mixed, all things considered, it must be asked: What could have been done to make the program better, provided that it was possible to have made it better? Even if implemented correctly, there is always the possibility that the EZ program would not have been enough to do the job KRS 154.45 intended it to do. Based on the results of my research, the following policy recommendations appear warranted.

First, for the program to at least have had a chance to work, I believe that the size of the EZ should not have been changed. The targeted area should have remained geographically small, urban, and in desperate need of economic assistance. The communities included in the Ez after its start in 1983 were not as bad off socially and economically as the original, targeted area. This fact probably diverted attention from the initial target of $\mathrm{EZ}$ incentives. However, retaining the focus on the original geographic area may not have been enough for the goals and objectives of KRS 154.45 to have been realized. As mentioned before, tax incentives and regulations are only one part of a whole group of 
considerations that businesses contemplate when making hiring, investment, and location decisions (Schmenner, 1982; and Blair, 1995). In order to revitalize an area like the original EZ, high-paying jobs would have had to have been created in the area. These jobs usually require high skill and educational levels, things that the original Ez still lacks to this day. Therefore, it is doubtful that, even if the boundaries of the original EZ had not changed, the EZ program would have been successful.

Making business costs as low as possible would certainly have been advantageous to the original EZ. In fact, if local economic development officials really wanted to take a supplyside approach to developing the original EZ, then one possible incentive may have been to eliminate all state and local taxes on EZ certified firms, including taxes on business profits.

But, once again, making an area attractive based upon low costs of doing business is not enough to encourage economic growth. If this were true, then Mississippi would be the fastest growing state in the U. S. Yet it is well known that it is one of the poorest states in the country. Thus, one policy implication of this study is that tax incentives and/or low tax rates alone are not enough to revitalize an impoverished area. This has been known for quite some time (Schmenner, 1982), but local economic development officials, in their rush to start an EZ program, ignored this important principle of economic development.

Instead, other things must be done to make an area ready 
for economic growth. An educated and skilled workforce is an advantage, as well as amenities that make the quality of life in an area good. To have accomplished this in the original EZ, innovative educational policies and crime prevention programs would be necessary, and these programs would probably have been very costly. It would also have meant cultivating a workforce in an area where a generation of adults have grown up without steady work, if any work at all. In this type of environment, creating a quality workforce would have been a very expensive and a long-run undertaking with no certainty of success. To have pursued such policies in the 1980 s and the 1990s may have also proven politically unfeasible, undoubtedly reminding many people of the controversial programs of the 1960 s and 1970 s.

Interestingly in Britain, enterprise zone policy has changed dramatically. Midway through the Thatcher administration, EZ designated areas were not only granted tax and regulatory relief, but were also given Urban Development Grants (UDGs) in order to help localities refurbish infrastructure, rebuild roads and sewers, and build workforce development centers. Ironically, UDGs appeared in Britain as UDAGS were being eliminated in the United States (Hambleton, 1996). In the U. S., Empowerment Zones and Enterprise Communities (EZ/EC) have been introduced as a replacement for the Reagan era EZ programs for urban areas. The EZ/EC concept is the first real federal urban policy initiative undertaken by the federal government since the 1970s. However, it is 
very modest in its size and goals when compared to the urban initiatives of the 1960 s and 1970s. Only selected cities get to participate in the program. One of the selling points of the EZ/EC program is that it creates partnerships between federal and local governments in carrying out EZ/EC policy, a partnership that was missing from previous federal programs where it was felt that Washington had too much control over urban policy. Like British policy, the EZ/EC initiative relies upon a mixture of tax relief and federal expenditures in order to try to revitalize distressed areas (Hambleton, 1996). So far, there is little known about how well the EZ/EC programs are working. Because it is limited to only a certain number of cities, not all of urban America is benefiting-a major criticism of the program.

One of the implications of studying Louisville and Jefferson County's Enterprise Zone is that state and local leaders have not done a very good job with regard to economic development and to the removal of urban poverty and blight. According to Rubin and Wilder (1996), this has not been an uncommon experience with EZs across the U. S. Poor planning, monitoring, and implementation of EZs caused Rubin and Wilder to conclude that no definite statement can be made as to whether EZs have been successful throughout the U. S. over the past two decades. This dissertation adds to their conclusion by confirming that many problems that plagued other Ezs in the U. S. also caused difficulties for Louisville's EZ.

So it seems that both federal and local government 
initiatives to solve urban problems have been criticized for coming up short on solutions to poverty and urban deterioration. If the federal initiatives of the 1960 s and 1970s did not work, and if the local government policies of the 1980 s and early 1990 s did not assist urban areas, then one cannot expect too much from the clinton administration's EZ/EC program because it attempts to use both levels of government in only selected cities to address urban issues. At best it appears to be a half-hearted attempt to redevelop the most economically depressed areas within cities.

\section{Policy Recommendations and Suggestions for Further Research}

I would like to put forth a simple yet bold proposal to help Louisville and other U. S. cities help the urban underclass. Instead of creating programs that are targeted toward areas and localities, perhaps the focus should be on creating programs that are targeted toward certain groups of people. The tax incentives given by and the tax revenues foregone by Louisville's EZ program may have been better spent by creating a negative income tax for the poor. In fact, perhaps all local and federal government programs would be more effective if this change in emphasis was considered seriously. Despite the controversy surrounding its current and future funding, no one can deny that social security has been a success in that the elderly now constitute the smallest percentage of those living in poverty. As far as an antipoverty program goes, Social security has thus far been a 
success whereas other anti-poverty programs have not. This is probably because social security is targeted toward a specified segment of the population rather than a specified area or region of the country.

The idea of a federal negative income tax has been around for some time (Samuelson, 1973, pp. 810-812). It has supporters who span the political and economic philosophical spectrum: from the likes of Keynesian economist James Tobin to the libertarian and Monetarist economist Milton Friedman. Other supporters have included Barry Goldwater, Richard Nixon and George McGovern. It has and still is used in various European nations. Instead of a negative income tax, some have suggested that it be called an "incentive-guaranteed-income" plan (p. 811). The closest thing to a negative income tax that exists now is the earned-income tax credit (EITC). However, negative income tax (NIT) proponents argue that the EITC does not go far enough.

How would a negative income tax program work? Those individuals or families with no income receive a guaranteed minimum income that is pre-determined. Individuals or households with an income level below some break-even level receive payments, with the level of payment being related to their level of income. They are not taxed on their earnings, but instead receive transfer payments to get them up to the guaranteed minimum income level. After an individual or a family begins to earn income above their guaranteed minimum income, they only then begin to make tax payments on their 
income, although the tax is progressive (i.e., to pay a great amount of taxes they would have to earn a great deal more). For example, let us assume that the federal government establishes that the guaranteed minimum income for a family of four is $\$ 18,000$ per year. A family of four with no income would receive $\$ 1,500$ per month. A family of four with an income of $\$ 9,000$ per year would receive a negative income tax payment of $\$ 750$ per month. Once a family of four begins to earn more than $\$ 18,000$ a year, each dollar earned over $\$ 18,000$ would be taxed at a tax bracket appropriate for that level of income.

Nobel-prize winning economist Paul Samuelson (1973) writes:

\footnotetext{
"Yet how can these aids be given them [the poor] so as not to deter their efforts and incentives? Here is where the negative income tax provides a great improvement over those welfare programs that deprive people of all assistance the moment they even get a poor job. (And, of course, those on assistance know this very well and are thus deterred from trying to improve their position.) .... [T] he formula for the negative income tax is gauged to leave the poor with more income after they have used their own efforts to raise their private earnings by a thousand dollars, or even by a dollar....

The paramount advantages of the negative income tax are many.

1. It can replace much of present welfare assistance that destroys incentives.

2 . It can help to equalize minimum levels of well-being over all the diverse regions of the United States.

3. It is less demeaning to the poor.

4. It can be simply administered by the Internal Revenue Service." (pp. 811-12).
}

A guaranteed income and NIT plan could be paid for by either reallocating money from current urban programs and 
anti-poverty programs to a NIT program, or by a modest. increase in gasoline taxes, or by doing both. ${ }^{30}$ This could be done without increasing the federal budget deficit. It would be a fairer and more humane way of changing urban assistance than by sticking to the old way of doing welfare (which was abolished in 1996), or by handing over welfare programs to state governments. I cite the welfare debate because of its importance to urban constituents.

The NIT would also do more to help the urban poor and underclass than CDBGs, UDAGs, public housing, mass transit systems or other programs which require state and local middlemen to implement the policies of the federal government. Bureaucratic "overhead" consumes a large portion of the costs of these policies. It is also a better alternative to alleviating urban poverty than what some advocates think that a national industrial policy would yield (Leigh, 1994). Such a policy would never work in the U. S. just as it has not worked in various other nations. Finally, if state and local governments cannot do economic development correctly, what makes one think that they can adequately provide assistance to the urban underclass?

The NIT proposal has been criticized on many grounds.

\footnotetext{
${ }^{30}$ American economists are quick to point out that Americans pay very little for gasoline compared to their European counterparts. When Presidential candidate Bob Dole proposed reducing federal gasoline taxes, most economists retorted that our gasoline taxes were in fact too low. Although a somewhat regressive tax, a gasoline tax increase would generate a huge amount of revenues in a short time period because short-run demand (several years) for gasoline is very price inelastic (Pindyck and Rubinfeld, 1995, pp. 32-37). 
To defend it in detail and to outline a plan for its implementation would be beyond the scope of this dissertation. However, with modern technology, computer monitoring, and bank debit cards, it seems that now is the time that new research should be done on the practical implementation of the NIT. New pilot projects would be in order. Some would argue that the NIT proposal would make the IRS too large. But the IRS would only grow in proportion to, maybe perhaps less than in proportion to, the amount by which other government agencies, such as welfare programs, the Economic Development Administration, HUD, etc., would shrink.

Even at the state level, the NIT could do much to help Kentucky's urban poor and working poor in general. Kentucky now ranks number one as far as its tax burden on the poor (Hawpe, 1996). Poor people are taxed at a higher rate in Kentucky than in any other state (Multistate Tax Commission, cited in Hawpe, 1996). No wonder there is so little incentive to work for those people with low skills and low educational levels. Instead of experimenting with EZs, perhaps Kentucky and other states with income taxes should try pilot NIT programs.

If one took the roughly $\$ 217$ million used in Chapter 8 as the conservative cost estimate for $\mathrm{EZ}$ program costs and divided this amount by 13 (for FYs 1983-84 to 1995-96), an average of $\$ 16,692,308$ per year could have been paid to qualified, low-income households in the original Ez. These are the households that were supposed to have been helped by 
KRS 154.45, but never really were. According to Table 6, in 1990, 64.4\% of all households in the original Ez were below poverty level. This percentage of the total occupied housing in the original $\mathrm{EZ}, 4,173$ in Table 2 , means that $2,687 \quad(=.644$ $\mathrm{X} 4$, 173) households lived below poverty in 1990 in this area. Had $\$ 16,692,308$ been given to these households in the form of a negative income tax, then the average income of each household would have risen by $\$ 6,212$, assuming that all households were the same and had the same needs. Adjustments in NIT payments would have to be made in order to account for variations in household size and earnings. This additional $\$ 6,612$ in income to each household would have raised average household income in the original EZ from around $\$ 11,132$ in 1990 to over $\$ 17,000$ per household.

Although this increase in income would not make the residents of this area middle class, at least it would give them the additional income needed to perhaps stimulate some new business activity in the area. Such additional income could also be used to take vocational education or community college classes. Perhaps it would also allow some families to become first-time home buyers. If this occurred, perhaps the neighborhood revitalization envisioned in KRS 154.45 would finally become a reality.

Critics can argue that these poor households would not know what to do with the additional money, and that the money would probably be squandered on drugs, alcohol and other illicit activities. My response would be that such socially 
deviant behavior is already occurring in this area. The extra income would be an incentive for those who want to better their lives. Those who would use the NIT to engage in illegal activities would lose benefits and suffer the consequences of their illegal or socially undesirable pursuits.

Others will say that such a plan is purely redistributive and only makes welfare a bigger problem. If one considers all the other welfare programs and agencies eliminated by adopting a NIT, the costs of welfare could actually go down, not up. Also, there are incentives built into the program to encourage participants to earn more money. This is not to say that the NIT will solve all the problems of the urban poor and urban areas. Public safety and education will still have to be promoted vigorously in Louisville and other urban areas as a way to help solve our problems. Better education is important for the urban poor to gain upward mobility. However, at least adopting the NIT would get the federal, state and local governments out of the business of local economic development. The NIT would allow state and local governments to concentrate on the services that they are supposed to do--public safety, education, sanitation, and other basic services. Constitutionally, these are the only areas on which they should be concentrating. 
BIBLIOGRAPHY

211 


\section{BIBLIOGRAPHY}

Ames, David, Nevin Brown, Mary Helen Callahan, Scott Cummings, Sue Marx Smock and Jerome Ziegler. 1992. "Rethinking American Urban Policy." Journal of Urban Affairs, Vol. $14(3 / 4)$, pp. 197-216.

Anderson, Martin. 1964. The Federal Bulldozer: A Critical Analysis of Urban Renewal, 1949-1962. Cambridge, MA: MIT Press.

Armstrong, Regina B. 1981. "The Enterprise Zone Concept: Fiscal and Urban Policy Issues. City Almanac, Vol. $16(1)$, pp. 11-15.

Bartik, Timothy. 1992. Who Benefits from State and Local Economic Development Policies? Kalamazoo, MI: W. E. Upjohn Institute.

Bell, Sarah. Personal Interview, March 6, 1996. Kentucky Revenue Cabinet, Frankfort, KY.

Bendavid-Val, Avrom. 1991. Regional and Local Economic Analysis for Practitioners, Fourth Edition. New York: Praeger Press.

Bendick, Jr., Marc and David W. Rasmussen. 1986. "Enterprise Zones and Inner-City Economic Revitalization." In George E. Peterson and Carol W. Lewis, editors, Reagan and the Cities, pp. 97-129. Washington, D. C.: Urban Institute Press.

Birdsong, Bret. 1989. Federal Enterprise Zones: A Poverty Program for the 1990s? Washington, D. C.: The Urban Institute.

Blair, John P. 1995. Local Economic Development: Analysis and Practice. Thousand Oaks, CA: Sage Publications.

Bluestone, Barry and Bennett Harrison. 1982. The Deindustrialization of America: Plant Closings, Community Abandonment, and the Dismantling of Basic Industry. New York: Basic Books, Publishers.

Brock, William R. 1988. Welfare, Democracy, and the New Deal. New York: Cambridge University Press.

Bromley, Rosemary and Richard Morgan. 1985. "The Effects of Enterprise Zone Policy: Evidence from Swansea." Regional Studies, Vol. 19(5), pp. 403-313.

Bromley, Rosemary and Joan Rees. 1988. "The First Five Years of the Swansea Enterprise Zone: An Assessment of Change." Regional Studies, Vol. 22(4), pp. 263-75. 
Buchanan, James M. 1960. "Social Choice, Democracy, and Free Markets." In James M. Buchanan, editor, Fiscal Theory and Political Economy-Selected Essays, pp. 75-89. Chapel Hill, NC: University of North Carolina Press. - 1965. "An Economic Theory of Clubs." Economica, vol. 32, pp. 1-14.

Butler, Stuart. 1981. Enterprise Zones: Greenlining the Inner Cities. New York: Universe Books.

- 1991. "The Conceptual Evolution of the Enterprise Zones." In Roy E. Green, editor, Enterprise Zones: New Directions in Economic Development, pp. 2740. Newbury Park, CA: Sage Publications.

- 1992. Testimony before the Subcommittee on Select Revenue Measures, Committee on Ways and Means, House of Representatives, U. S. Congress. $102^{\text {nd }}$ Congress, $1^{\text {st }}$ Session, June 25 and July 11.

Clarke, Susan E. 1982. "Enterprise Zones: Seeking the Neighborhood Nexus. Urban Affairs Quarterly, Vol. $18(1)$, pp. 53-71.

Congressional Digest. 1985. "Is the Proposed Reagan Enterprise Zone Program A Sound Approach to the Nation's Urban Problems?" May, pp. 139-59.

Cook, Thomas D. and Donald T. Campbell. 1979. QuasiExperimentation: Design and Analysis Issues for Field Settings. Boston, MA: Houghton Mifflin Co.

Coomes, Paul A. and Michael Price. 1994. Jefferson County Forecasts of People, Jobs, and Housing: 1995 to 2020. Louisville, KY: Published by Cornerstone 2020 .

Coomes, Paul A. and Barry Kornstein. 1996. 1995 Macro Performance Indicators. Louisville, KY: Study funded by National City Bank.

Cowden, Richard. 1992. Testimony before the Subcommittee on Economic Stabilization, Committee on Banking, Finance and Urban Affairs, House of Representatives, U. S. Congress, $2^{\text {nd }}$ Session, February 20.

Cummings, Scott and Michael Price. 1990. Race Relations in Louisville: Southern Racial Traditions and Northern Class Dynamics. Policy Paper Series Monograph, Urban Research Institute. Louisville, KY: University of Louisville. 
Dabney, Dan. 1988. Enterprise Zones and their Relationship to Business Location Decisions. Unpublished Ph. D. Dissertation, University of Texas.

Davidson, Joe. 1992. "An Enterprise Zone Just Grows and Grows around Louisville, Ky." The Wall Street Journal, August 26, pages $A 1$ and $A 2$.

Dowall, David E. 1996. "An Evaluation of California's Enterprise Zone Programs." Economic Development Quarterly, Vol. 10(4), pp. 352-68.

Erickson, Rodney A., Susan W. Friedman, and Richard E. McCluskey. 1989. "Enterprise Zones: An Evaluation of State Government Policies." Report to the U. S. Economic Development Administration. State College, PA: The Pennsylvania State University Center for Regional Business Analysis.

Erickson, Rodney A. and Susan W. Friedman. 1991. "Comparative Dimensions of State Enterprise Zone Policies." In Roy E. Green, editor, Enterprise Zones: New Directions in Economic Development, pp. 155-176. Newbury Park, CA: Sage Publications.

Estes, Ralph and M. Jeff Hamond. 1992. Enterprise Zones: $A$ Critical Analysis. Briefing Paper. Washington, D. C.: Center for the Advancement of Public Policy and the Institute for Policy Studies. July.

Feldstein, Martin S. 1969. "The Effects of Taxation on RiskTaking." Journal of Political Economy, Vol. 77, pp. $755-64$.

- 1979. "Does the United States Save Too Little?" American Economic Review, Papers and Proceedings, Vol. 87, pp. 116-21.

Friedman, Milton. 1962. Capitalism and Freedom. Chicago: University of Chicago Press.

Funkhouser, Richard and Edward Lorenz. 1987. "The Fiscal and Employment Impacts of Enterprise Zones." Atlantic Economic Journal, Vol. 15(2), pp. 62-76.

Gaffikin, Frank and Barney Warf. 1993. "Urban Policy and the post-Keynesian State in the United Kingdom and the United States." International Journal of Urban and Regional Research, Vol. 17(1), pp. 67-87.

Galbraith, John Kenneth. 1976. The Affluent Society, Third Edition, Revised. Boston, MA: Houghton Mifflin Co. 
Glickman, Norman J. 1984. "Economic Policy and the Cities: In Search of Reagan's Real Urban Policy." Journal of the American Planning Association, Vol. 50(4), pp. 471478 .

Glover, Glenda. 1993. Enterprise Zones: Incentives are not Attracting Minority Firms." Review of Black Political Economy, Vol. $22(1)$, pp. 73-99.

Goldsmith, William W. 1982. "Bringing the Third World Home." New Society for Working Papers, Vol. 9 (March/April), pp. 24-30.

Gramlich, Edward M. 1981. Benefit-Cost Analysis of Government Programs. Englewood Cliffs, NJ: PrenticeHall.

Green, Roy. 1991. Enterprise Zones: New Directions in Economic Development. Newbury Park, CA: Sage Publications.

Gunther, William D. and Charles G. Leathers. 1987. "British Enterprise Zones: Implications for U. S. Urban Policy." Journal of Economic Issues, Vol. 21(2), pp. 885-93.

Hall, Peter. 1977. "Green Fields and Grey Areas." In Proceedings of Royal Town Planning Institute Annual Conference, Chester. London: Royal Town Planning Institute.

1982. "Enterprise Zones: A Justification." International Journal of Urban and Regional Research, Vol. 6(3), pp. 416-421.

Hambleton, Robin. 1996. "Empowerment Zones and UK Urban Policy: Competing in the Urban Regeneration Game." Paper presented at the Urban Affairs Association Annual Conference, New York, March 13-16.

Harrison, Bennett. 1982. "The Politics and Economics of the Urban Enterprise Zone Proposal: A Critique." International Journal of Urban and Regional Research, Vol. 6(3), pp. 422-428.

Harrison, Bennett and Sandra Kanter. 1978. "The Political Economy of States' Job-Creation Business Incentives. Journal of the American Institute of Planners, Vol. $44(4)$, pp. 424-35.

Haveman, Robert H. and Julius Margolis. 1983. Public Expenditures and Policy Analysis, Third Edition. Dallas: Houghton Mifflin Co. 
Hawkins, Benjamin M. 1984. "The Impact of the Enterprise Zone on Urban Areas." Growth and Change, Vol. 15(1), pp. 35-40.

Hawpe, David. 1996. "Alms for rich, courtesy of working poor." The Courier-Journal, April, 21, page D1.

Heath, David. Personal interview, January 30, 1996. CourierJournal Building, Louisville, KY.

Heath, David. 1991. "Enterprise Zones: A Hollow Promise." The Courier-Journal, December 1 , pages $A 1$ and A18.

- 1992. "Kentucky Enterprise Zones' Legality

Questioned: Attorney General's Office Says Aiding 10 Areas Arbitrary." The Courier-Journal, May 16, page B12.

Heller, Walter W. 1966. New Dimensions of Political Economy. Cambridge, MA: Harvard University Press.

Hicks, John R. 1967. Critical Essays in Monetary Theory. Oxford: Oxford University Press.

Hoover, Edgar M. and Frank Giarratani. 1984. An Introduction to Regional Economics, Third Edition. New York: Alfred A. Knopf Publishers.

Howington, Patrick. 1997. "Innovation helps meet airport's rising costs." The Courier-Journal, March 23, pages E1 and $E 4$.

Hughes, Jonathan and Louis P. Cain. 1994. "Chapter 17: Industrialization and Urban Growth." American Economic History, Fourth Edition. New York: HarperCollins College Publishers.

1994. "Chapter 25:

The Great Depression and the New Deal." American Economic History, Fourth Edition. New York: HarperCollins Publishers.

- 1994. "Chapter 29:

Tertiary Sector and the Labor Force." American Economic History, Fourth Edition. New York: HarperCollins Publishers.

Humburger, Edward. 1981. "The Enterprise Zone Fallacy. Journal of Community Action (September/October), pp. 2028. 
Jacobs, Susan and Michael Wasylenko. 1981. "Government Policy to Stimulate Economic Development: Enterprise Zones. In N. Walzer and D. L. Chicoine, Financing State and Local Government in the 1980s: Issues and Trends. Cambridge, MA: Oelgeschlager, Gunn, and Hain.

Jones, Earl R. 1985. Enterprise Zones Programs and Neighborhood Revitalization: The First Two Years. Urbana, IL: University of Illinois.

1987. "Enterprise Zones for the Black Western Journal of Black Studies, Vol. 11(1), pp. 1-10.

Kemp, Jack. 1982. "A Case for Enterprise Zones." Nation's Business, November, pp. 54-56.

1989. "Enterprise Zones: Restoring Hope to America's Inner Cities." Testimony before the Subcommittee on Economic Stabilization, House Committee on Banking, Finance and Urban Affairs, South Bronx, New York, April 3.

- 1992. Testimony before the Subcommittee on Economic Stabilization, Committee on Banking, Finance and Urban Affairs, House of Representatives, U. S. Congress. $102^{\text {nd }}$ Congress, $2^{\text {nd }}$ Session, February 20.

Kentucky Cabinet for Economic Development. 1985, 1990 and 1994 Kentucky Handbook of Economic Statistics.

Frankfort, KY: Kentucky State Government.

Kentucky Legislative Research Commission. 1991. Report of the 1990 Enterprise Zones in Kentucky, Research Memorandum No. 460. Frankfort, KY: Kentucky State Government.

Kentucky Revised Statutes. 1994 Edition. Kentucky Revised Statues, Subchapter 45: Enterprise Zone Development. Pages 412-423.

Keynes, John Maynard. 1936. The General Theory of Employment, Interest and Money. New York: Harcourt, Brace and Co.

Koebel, C. T. and John Remington. 1988. "Strike City Revisited." Urban Resources, Vol. 4(3), pp. 72-76.

Ladd, Helen and Fred C. Doolittle. 1982. "Which Level of Government Should Assist the Poor?" National Tax Journal, September, pp. 385-99. 
Laffer, Arthur. 1979. "Statement Prepared for the Joint Economic Committee, May 20." In Arthur Laffer and Jan P. Seymour, editors, The Economics of the Tax Revolt: A Reader, pp. 75-79. New York: Harcourt Brace Jovanovich.

Leigh, Nancey Green. 1994. Stemming Middle-Class Decline: The Challenges to Economic Development Planning. New Brunswick, NJ: Center for Urban Policy Research.

Levitan, Sar and Elizabeth Miller. 1992. Enterprise Zones: A Promise Based on Rhetoric. Occasional Paper. Washington, D. C.: Center for Social Policy Studies, George Washington University.

Litster, Elaine. 1990. California Enterprise Zones: Assessment of Enterprise Zone Effectiveness and the Resulting Impact on Business Location and Employment. Unpublished Master's thesis. Department of Urban Planning, University of California at Los Angeles.

Louisville and Jefferson County office for Economic Development Annual Reports. 1983 to 1996. Published by City of Louisville and Jefferson County Fiscal Court.

Louisville and Jefferson County Office for Economic Development. 1990. The Louisville Enterprise Zone: Louisville's $\$ 1$ Billion Success Story. January 23 Press Release by OED.

The Louisville/Jefferson County Enterprise Zone. June 21 Press Release.

Massey, Doreen. 1982. "Enterprise Zones: A Political Issue." International Journal of Urban and Regional Research, Vol. 6(3), pp. 429-34.

Massey, Steve. 1985. "Manufacturing's Disappearing Act May Put Pinch on Pocketbooks." The Courier-Journal, January 6, pages $\mathrm{E} 1$ and $\mathrm{E} 3$.

McGowan, Paul. Personal interview, September 26, 1996. Office for Economic Development, Louisville, KY.

Mier, Robert. 1982. "Enterprise Zones: A Long Shot." Planning, Vol. 48 (April), pp. 10-14.

Mikesell, J. 1982. Fiscal Administration: Analysis and Application for the Public Sector. Homewood, IL: Dorsey Press.

The MIT Dictionary of Modern Economics, Third Edition. Edited by David W. Pearce. Cambridge, MA: MIT Press. 
Mounts, Richard. 1981. "Urban Enterprise Zones: Will They Work?" American Review of Public Administration, Vol. $15(1)$, pp. 86-96.

Murray, Charles. 1984. Losing Ground: American Social Policy, 1950-1980. New York: Basic Books.

Musgrave, Richard A. 1959. The Theory of Public Finance: A Study in Public Economy. New York: McGraw-Hill Co.

Nelson, Arthur C. and Robert W. Whelan. 1988. "Do Enterprise Zones Make a Difference: Survey Research Results of Louisiana's Rural Enterprise Zones." Paper presented at the $18^{\text {th }}$ Annual Meeting of the Urban Affairs Association, St. Louis, MO, March 9-12.

Nelson, John P. Personal interview, March 14, 1997. Urban Studies Institute. Louisville, KY.

Nicholson, Paul. Personal interview, June 28, 1996. Louisville and Jefferson County Department of Inspections, Permits, and Licenses, Louisville, KY.

Norman, Phil and Ben Z. Hershberg. 1984. "Industrial Exodus leaves behind a Residue of Economic Problems." The Courier-Journal, January 29, pages A1 and A22.

Oates, Wallace E. 1977. "An Economist's Perspective on Fiscal Federalism." In Chapter 1, Wallace E. Oates, editor, The Political Economy of Fiscal Federalism. Lexington, MA: Lexington Books.

O'Huallachain, Breandan and Mark A. Satterwaite. 1992. "Sectoral Growth Patterns at the Metropolitan Level: An Evaluation of Economic Development Incentives." Journal of Urban Economics, Vol. 31(1), pp. 25-58.

Okun, Arthur M. 1981. Prices and Quantities. Washington, D. C.: The Brookings Institution.

o'Sullivan, Arthur. 1993. Urban Economics, Second Edition. Boston, MA: Irwin Publishers.

Papke, Leslie E. 1993. "What Do We Know About Enterprise Zones?" In James M. Poterba, editor, Tax Policy and the Economy, pp. 37-72. Cambridge, MA: MIT Press.

- 1994. "Tax Policy and Urban Development: Evidence from the Indiana Enterprise Zone Program." Journal of Public Economics, Vol. 54(1), pp. 37-49.

Peirce, Neal R., Jerry Hagstrom, and Carol Steinbach. 1979. Economic Development: The Challenge of the 1980s. Washington, D. C.: Council of State Planning Agencies. 
Peterson, Paul. 1981. City Limits. Chicago: University of Chicago Press.

Pindyck, Robert S. and Daniel L. Rubinfeld. 1995. Microeconomics, Third Edition. Englewood Cliffs, NJ: Prentice-Hall.

Pressman, J. L. and Aaron Wildavsky. 1980. Implementation. Berkeley, CA: University of California Press.

Rossi, Peter and Howard Freeman. 1983. Evaluation: A Systematic Approach, Third Edition. Beverly Hills, CA: Sage Publications.

Rosen, Harvey. 1992. Public Finance, Third Edition. Boston, MA: Irwin Publishers.

Rubin, Barry M. and Margaret G. Wilder. 1989. "Urban Enterprise Zones: Employment Impacts and Fiscal Incentives." Journal of the American Planning Association, Vol. 55(4), pp. 418-431.

Rubin, Barry M. and C. Kurt Zorn. 1985. Sensible State and Local Economic Development." Public Administration Review, Vol. 45(2), pp. 333-39.

Rubin, Dale F. 1993. "Constitutional Aid Limitation Provisions and the Public Purpose Doctrine." St. Louis University Public Law Review, 12(1): pp. 143-67.

- 1994. "The Public Pays, the Corporation Profits: The Emasculation of the Public Purpose Doctrine and a Not-for-Profit Solution." University of Richmond Law Review, 28(5): 1311-46.

Rubin, Marilyn and Regina B. Armstrong. 1989. "The New Jersey Urban Enterprise Zone Program: An Evaluation." Report prepared for the New Jersey Department of Commerce, Energy and Economic Development, July.

Rubin, Marilyn, Steven A. Brooks, and Richard W. Buxbaum. 1992. "Indiana Enterprise Zones: A Program Evaluation for 1989 and 1990. Report prepared for the Indiana Department of Commerce, October.

Ruffin, Roy and Paul Gregory. 1994. Principles of Macroeconomics, Fifth Edition. New York: HarperCollins Publishers.

Saint Louis Federal Reserve Branch District, Home Mortgage Disclosure Act Data Bank. 1981 to 1994. St. Louis: Federal Reserve Board of Governors. 
Samuelson, Paul A. 1973. Economics, Ninth Edition. New York: McGraw-Hill Book Co. - 1975. Foundations of Economic Analysis, Second Edition. Cambridge, MA: Harvard University Press.

Savitch, Hank and Ronald Vogel. 1996. Report to the Jefferson County Fiscal Court on Final Recommendations of the Jefferson County Governance Project. Report prepared for County Commissioner Daryl Owens.

Schlesinger, Jr., Arthur M. 1958. "Chapter 16: The Rise of Federal Relief." The Age of Roosevelt, Volume 2: The Coming of the New Deal. Boston, MA: Houghton Mifflin, Co.

Schofield, J. A. 1987. Cost-Benefit Analysis in Urban and Regional Planning. London: Allen and Unwin.

Schulman, Robert. 1987. "A Splitsville Called Louisville." Urban Resources, Vol. 4(2), pp. Lo1-Lo6 (insert).

Seyfried, William L. 1990. The Impact of Enterprise Zones on Local Economies. Unpublished $\mathrm{Ph}$. D. dissertation. Purdue University.

Shafer, Sheldon. 1984. "Rezoning planned for 12,000 tracts in Enterprise Zone." The Courier-Journal, October 10, pages $B 1$ and $B 4$. 1985. "Panel to recommend urban enterprise
zone expansion." The Courier-Journal, January 23, page
B1.

- 1985. "Plan would triple size of Enterprise Zone." The Courier-Journal. August 23, page C2.

- 1985. "Extend Enterprise Zone into County, panel says." The Courier-Journal, August 29, page B4.

- 1985. "County taxes option on 550 acres to lure major industry, jobs." The Courier-Journal, November 27 , page A1.

- 1986. "Economic development efforts are hampered until legislature acts." The Courier-Journal, February 3, pages B1 and B4.

- 1986. Fiscal Court OKs expansion of enterprise zone." The Courier-Journal, December 10, page $B 3$. 
1996. Business Enterprise Zone May Grow:

Downtown, key industrial areas would be part of

expansion." The Courier-Journal, August 14, page E1.

Shapero, Ken. Telephone interview, October 11, 1996, Louisville, KY.

Solow, Robert W. 1970. Growth Theory. Oxford: Oxford University Press.

Spulber, Nicolas. 1989. Managing the American Economy: From Roosevelt to Reagan. Bloomington, IN: Indiana

University Press.

Sridhar, Kala Seetharam. 1996. "Tax Costs and Employment Benefits of Enterprise Zones." Economic Development Quarterly, Vol. 10(1), pp. 69-90.

Stahl, Linda. 1997. "New homes sprout at boom-town rate." The Courier-Journal, February, 19, page A1.

- 1997. "Taylorsville Road emerges as latest housing hot spot." The Courier-Journal, Neighborhoods, page 1 .

Stein, Herbert. 1996. The Fiscal Revolution in America: Policy in Pursuit of Reality, Second Edition. Washington, D. C.: The AEI Press.

Stewart, Kay. 1983. "Sloane favors area near downtown for enterprise zone." The Courier-Journal, March 23, page B1.

Stiglitz, Joseph. 1988. Economics of the Public Sector, Second Edition. New York: W. W. Norton Co. Publishers.

Tabb, William K. 1984. "The Failures of Urban National Policy." In William K. Tabb and Larry Sawers, editors, Marxism and the Metropolis, Second Edition. New York: Oxford University Press.

Tabb, William K. and Larry Sawers. 1978. Marxism and the Metropolis, First Edition. New York: Oxford University Press.

Talbot, Jonathan. 1988. "Have Enterprise Zones Encouraged Enterprise? Some Empirical Evidence from Tyneside." Regional Studies, Vol. 22(6), pp. 507-514.

Tiebout, Charles M. 1956. "A Pure Theory of Local Expenditures." Journal of Political Economy, Vol. 64, pp. 415-24. 
U. S. Bureau of the Census, County Business Patterns for Kentucky, 1970 through 1994 editions. Washington, D. C.: Department of Commerce.

County Business Patterns for the United States, 1980, 1981, 1990, and 1994 editions. Washington, D. C.: Department of Commerce.

, 1980 Census of Population and Housing. Washington, D. C.: Department of Commerce. 1983 County-City Data Book. Washington, D. C.: Department of Commerce.

, 1988 County-City Data Book. Washington, D. C.: Department of Commerce.

, 1990 Census of Population and Housing. Washington, D. C.: Department of Commerce.

U. S. Department of Housing and Urban Development. 1986. State-Designated Enterprise Zones: Ten Case Studies. Washington, D. C.: Dept. of Housing and Urban Development.

Vaughn, Roger J. 1979. State Taxation and Economic Development. Washington, D. C.: Council of State Planning Agencies.

Ward, Joe. 1996. "Appliance Park union leader to retire." The Courier-Journal, November 27, page C1.

Walton, John. 1982. "Cities and Jobs and Politics." Urban Affairs Quarterly, Vol. 18 (September), pp. 5-17.

Weimer, David and Aidan Vining. 1992. Policy Analysis: Concepts and Practice, Second Edition. Englewood Cliffs, NJ: Prentice-Hall, Inc.

Weiner, Stuart E. 1984. "Enterprise Zones as a Means of Reducing Structural Unemployment." Economic Review, March, pp. 3-16.

Wilder, Margaret G. and Barry M. Rubin. 1996. "Rhetoric versus Reality: A Review of Studies of State Enterprise Zone Programs." Journal of the American Planning Association, Vol. 62(4), pp. 473-491.

Wilson, Cynthia. 1996. "Station Park: Urban Planning at Work." The Courier-Journal, April 7, pages E1 and E2.

Wilson, James Q. 1966. Urban Renewal: the Record and the Controversy. Cambridge, MA: MIT Press. 
Wilson, William Julius. 1987. The Truly Disadvantaged: The Inner City, the Underclass, and Public Policy. Chicago: University of Chicago Press.

Wilson, William Julius. 1996. When Work Disappears: The World of the New Urban Poor. New York: Alfred A. Knopf, distributed by Random House.

Wylie, Jeanie. 1989. Poletown: A Community Betrayed. Urbana, IL: University of Illinois Press. 
APPENDIX

225 
gages, leases, assignments, loans, and all other matters relating to its fi. nancial operations. Copies of the audit shall be distributed to all members of the board, the Governor, and the Kentucky Legislative Research Commission and shall be made generally available to the public for inspection. (Enact. Acts 1990, ch. 105, \& 18, effective March 20, 1990.)

Compiler's Notes. This section was formeriy compiled as KRS 154B.134.

\section{SUbchapter 45. EnTERPRISE ZONE Development}

154.45-001. Purpose of Enterprise Zone Program. - The General Assembly hereby finds and declares that the purpose of the Enterprise Zone Program is to revitalize economically depressed areas of the state. It is the intent of the General Assembly to achieve this purpose by adhering to the following goals:

(1) Improve the quality of life of individuals that reside within an enterprise zone by providing employment opportunities, job training, and neighborhood improvement programs;

(2) Encourage economic activity by assisting and maintaining existing business within an enterprise zone;

(3) Encourage economic activity by stimulating the influx of new business within an enterprise zone; and

(4) Eliminate blighted and deteriorated areas within an enterprise zone that feature chronic abandonment or demolition of residential or commercial structures or property. (Enact. Acts 1982, ch. 131, \& 1, effective July 15,$1982 ; 1986$, ch. 30 , \& 1, effective July 15, 1986; 1992, ch. 35 , \& 1, effece tive July 14, 1992.)

Compiler's Notee This section wal for mety compiled as KRS 154.650.

Kentrechy Bench Bar. Toberste, The Impact of Kentucky's Present Constitution Upon Burineses Growth \& Developmenth, Volume 61, No. 3, Summer 1987 Ky. Bench \& Ber 21.

Kentweky LaT Journal. Kentucky Law Survey, Whiteaide, Taration, 71 Ky. LN. 479 (198283).

Northers Kentucls Law Review. Note, Feeing the Economic Challenges of the Bighties - the Kentucky Conetitution and Hayes v. The State Property and Buildings Commisaion of Kentucky, 15 N. Ky. L. Rev. 645 (1988).

Optinions of Attorney General. Public'a intereat in monitoring the sctivities of Enter. prive Zone Authority to determine if the buginewese certified for the rones qualify for the benefite received by virtue of their invest. ments and the number of jobs they claim to create, outweighe those buaineseces' interest in maintaining the confidentiality of infor. mation relating to capital inveatments and employment figures for busineeses located in enterpries rones; therefore, to the extent that the requested informntion does not relate to the buaineeses' personal financial anta, but merely reflects their compliance with the re quirements for certification under K::3 154.45-010(7), such information ahould prop. exty be disclosed under subdivision (1)(a) af KRS 61.878. OAG 91-105.

Limitation of the benefits under the onter prien soees program to ten areas celected by the enterpriee sone authority does in fact cose for a epecial status on these areas denying benefits they receive to other areas aimilariy situnted; since unique besefits are provided to deaignated areas having no natural and reasonable banis to distinguish them from other similarly viturated areas, and aines the lepialntion in question exempte certain dip tricts from the operation of general lawe, the legialation is both local and special in charno ter, and thus violative of sections 59 and 60 of the Constitution of Kentuctsr, therefors, the following cections ase unconstitution r vloenl

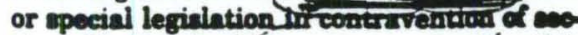
tions 69 and 60 of the state constitution: thin section, KDS 154.45-020, 154.45-080, 154.45-040, 154.45-060, 154.45-070, and 154.45.000; furthermore, although Hous Bill 66, [Act 1992, ch. 35] enacted by the 1992 General Aseombly, makes numercos 
changes to various provisions in the enter- fice did not find that it affected the conciusion prive zone statutes the Attorney General's of- of unconstitutionality. OAG 92-86.

154.45-010. Definitions for KRS 154.45-020 to 154.45-110. - As used in KRS 154.45-020 to 154.45-110, unless the context otherwise requires:

(1) "Authority" means the Enterprise Zone Authority of Kentucky;

(2) "Enterprise zone" means an area designated by the authority to be eligible for the benefits of KRS 154.45-020 to 154.45-110;

(3) "Establishment" means a single physical location where business is conducted or where services or industrial operations are performed;

(4) "Existing business" means a person, corporation, or other entity engaged in the active conduct of a trade or business at a location within the enterprise zone prior to the date the authority designated the area as an enterprise zone;

(5) "Local government" means a city, county, urban-county government, or charter county government;

(6) "New business" means a person, corporation, or other entity who was not engaged in the active conduct of a trade or business in the enterprise wne prior to the date the authority designated the area as an enterprise wne, and who becomes engaged in the active conduct of a trade or business within the enterprise zone after the date the authority designated the area as an enterprise zone;

(7) "Qualified business" means an existing business or new business that his been certified by the authority to have at least fifty percent (50\%) of its employees performing substantially all of their services within an enterprise zone and meeting one (1) of the following criteria:

(a) With a new business employing at least twenty-five percent (25\%) of the business's employees from the targeted workforce; or

(b) With an existing business creating new activity within the enterprise wone of not less than a twenty percent (20\%) increase in the number of employees or by a twenty percent (20\%) increase in capital investment within eighteen (18) months from the date of application for certification as a qualified business. Businesses that are certified based upon an increase in employees shall employ at least twenty-five percent (25\%) of the new employees from the targeted workforce.

(8) "Qualified employee" means an employee of a qualified business; and

(9) "Targeted workforce" means Kentucky residents:

(a) Who reside within an enterprise zone; or

(b) Who have been unemployed for at least ninety (90) days or who have received public assistance benefits, based on need and intended to alleviate poverty, for at least ninety (90) days prior to employment with a qualified buainess.

(c) For the purpose of this subsection, "Kentucky resident" means a person who has resided in the Commonwealth for at least ninety $(90)$ days. (Fnact. Acts 1982, ch. 131, § 2, effective July 15, 1982; 1986, ch. 30, \& 2, effective July 15, 1986; 1992, ch. 35, \& 2, effective July 14, 1992.)

Compiler's Notee. This rection was formeriy compiled as KRS 154.655.

Kentucky Lav Jouraal Kentucky Law Survey, Whiteaide, Tarration, 71 Ky. LJ. 479 (1982-83).

Optnions of Attorney General. Public's interest in monitoring the activities of Enter- prive Zone Authority to determine if the buaineanes certified for the rones qualify for the benefits received by virtue of their inveets ments and the number of jobs they einim to create, outweighs those businesese' interest in maintaining the confidentinility of infor. mation relating to capital investment and 
employment figures for businesees located in enterprise zones, therefore, to the extent that the requested information does not relate to the businesses' personal financial data, but merely reflects their compliance with the re- quirements for certification under subecetion (5) (now (7)) of this section, such information should properiy be disclosed under rubdivi. sion (1)(a) of KRS 61.878. OAG 91-105.

154.45-020. Application for designation as enterprise zone - In. terlocal governmental agreement - Application to amend boundaries of existing zone - Joint applications. - (1) A local government may, by act of the local legislative body, designate an area within its juris. diction to be an economically depressed area. The local government may then make written application to the authority to have the area declared to be an enterprise zone. The application shall include a description of the location of the area and other information the authority may require.

(2) Two (2) or more local governments may, by an act of each respective legislative body, designate an area within their collective jurisdictions to be an economically depressed area. After each local government has enacten the proper ordinances designating the area to be economically depresad in? the purpose of applying to the authority for designation as an enterpersts zone, each legislative body shall enter into an interiocal governmental agreement. The agreement shall be governed by the provisions of the Inter. local Cooperation Act, KRS 65.210 to 65.300, and shall include:

(a) The establishment of a joint board to administer the enterprise rone that shall be comprised of representatives from each local government;

(b) A statement establishing the joint board for the life of the enterprise zone;

(c) A statement establishing uniform local incentives that shall be fered by each local government;

(d) A statement establishing financial support by each local governmemt for the administration of the joint boand; and

(e) Other requirements that may be established by the authority.

(3) A local government with an existing enterprise zone may apply to the authority to amend the boundaries of the existing zone for the purpose of joining with other local governments. A local government applying to croes? jurisdictional boundaries to amend the area of an enterprise zone shail" comply with the provisions of subsection (2) of this section and KRS 154.45-030.

(4) Upon approval of the interiocal governmental agreement pursuant to KRS 65.210 to 65.300, two (2) or more local governments may make written application to the authority to have the area declared an enterprise rone. The application shall inciude a description of the area and other informen tion the authority may require.

(5) Upon receipt of an application, the authority shall review the application to determine if the area described in the application qualifies to be designated an enterprise rone.

(6) The authority shall complete its review within one hundred twenty (120) days of receipt of the application, but may extend this time period an additional sixty (60) days if necessary. If the authority denies the application, it shall inform the local government of the fact in writing along with reasons for the denial. (Enact. Acts 1982, ch. 131, \& 3, effective July 15, 1982; 1986, ch. $30, \& 3$, effective July 15,$1986 ; 1992, c h .35, \& 3$, effective,
July $14,1992$. 
Compiler' Notes. This rection was formeriy compiled as KRS 154.660.

Bentucky Lav Journal. Kentucky Law Survey, Whiteside, Taration, 71 Ky. LN. 479 (1982-83).

Opinions of Attorney General Limita. tion of the benefits under the enterprise noes program to ten areas selected by the caterprise sone authority does in fact confer a ppecial status on theme areas, denying benefits they recaive to other areas aimilariy situated; since unique benefits are provided to decignated areas having no natural and reacoable basis to dirtinguish them from other similarly situnted arean, and since the legit lation in question exempts certain distriet from the operation of general lawe, the legitlation is both local and special in chrracter, and thus violative of sections 59 and 60 of the Constitution of Kentucky, therefore, the following sections are unconstitutional local or special legialation in contravention of tions 69 and 60 of the state constitution: KRS 154.45-001. this section, 154.45-030, 154.45-040, 154.45-050, 154.45-070, and 154.45-090; furthermore. although House Bill 66. [Acts 1992, ch. 35] enacted by the 1992 General Assembly, makes numerous changes to various proviaions in the enters priee sone statutes the Attorney Geseral's office did not find that it affected the coneiunion of unconstitutionality. OAG $92-86$.

154.45-030. Boundary changes effective upon written approval of anthority - Contents of application - Requirements for authority? approval. - (1) A local government may make written application to the authority for purposes of amending the boundaries of an existing enterprise wne. A boundary change to an existing enterprise zone shall not become effective until after written approval has been granted by the authority.

(2) A local government applying to the authority for an amendment to the boundaries of an existing enterprise zone shall certify in writing the following information:

(a) The proposed area for amendment is contiguous to the existing rone;

(b) The proposed area for amendment independently meets the requiremonts established by KRS 154.45-040; and

(c) A statement documenting the reasons the local government is seeking to amend the boundaries of its existing enterprise zone. A detailed map showing original boundary lines and proposed boundary line changee ahail be attached to the application.

(3) Prior to granting approval for amending the boundaries of an existing enterprise zone, the authority shall verify and document in writing the following:

(a) How amending the boundaries of the existing zone will comply with the goals established pursuant to KRS 154.45-001;

(b) The local government's commitment and incentives to be offered to support the expanded enterprise zone;

(c) If two (2) or more local governments are involved, that each local government has met the requirements of KRS 154.45-020;

(d) The local government's attempt to utilize available buildings and properties within the existing zone; and

(e) Unforeseen circumstances or overriding economic factors that have oceurred since the designation of the original zone that necessitate amending the boundaries of the existing zone. (Enact. Acts 1986, ch. 30, \& 4, effective July 15, 1986; 1992, ch. 35, \& 4, effective July 14, 1992.)

Compiler's Notes. This section was for marly compiled as KRS 154.662 .

Opinions of Attorney General. Limita. tion of the bencits under the enterprive sones program to ten areas seilected by the enterprive sone authority does in fact confer a epecial status on these areas, denying bene- fits they receive to other areas aimilarty aito ated; aince unique benefite are providad to denignated areas having no natural and reasonable barin to distinguish thom from other similariy aituated areas, and tines the lexilation in quention exempte certain dintricte from the operntion of reaner lawn, the legie 
lation is both local and special in character. and thus violative of sections 59 and 60 of the Constitution of Kentucicy; therefore, the following sections are unconstitutional local or special legisiation in contravention of sections 59 and 60 of the state constitution: KRS 154.45-001. 154.45-020, this section. $154.45-040,154.45-050,154.45-070$, and
154.45-090: furthermore, although House Bill 66, (Acts 1992, ch. 35) enacted by the 1992 General Assembly, makes numerrous changes to various provisions in the entar. prise rone statutes the Attorney General's office did not find that it affected the conciunion of unconstitutionality. OAG 92-86.

154.45-040. Areas eligible for designation as enterprise zone. (1) Any area of a local government may be designated an enterprise zone that:

(a) Has a continuous boundary, and

(b) Is an area of pervasive poverty, unemployment, and economic distress.

(2) An area meets the requirements of subsection (1)(b) of this section if:

(a) The average rate of unemployment in the area for the most recent eighteen (18) month period for which data is available was at least one and one-half $(1-1 / 2)$ times the average national rate of unemployment for that eighteen (18) month period; and

(b) At least seventy percent (70\%) of the residents living in the area have incomes below eighty percent (80\%) of the median income of the residents of the local government requesting designation of an enterprise zone; or -

(c) The population of all census tracts in the area decreased by ten percent (10\%) or more between 1980 and 1990 and the local government requesting designation establishes in writing, to the satisfaction of the authority, that either:

1. Chronic abandonment or demolition of commercial or residential structures exist in the area, or

2. Substantial tax arrearages of commereial or residential structures exist in the area. (Enact. Acts 1982, ch. 131, \& 4, effective July 15, 1982; 1992, ch. 35, \& 5, effective July 14, 1992.)

Compiler's Notee. This section was formeriy compiled as KRS 154.665.

Kentueky La Journal. Kentucky Law Survey, Whitecide, Taration, 71 Ky. L.J. 478 (1982-83).

Optnions of Attorney General Limita. tice of the benefits under the enterprise rones program to ten areas seiected by the enterprise sone authority does in fact confer a special etatus on these areas, denying benefits they receive to other areas similarty aituated; since unique benefits are provided to decignated areas having no natural and reasonable basis to distinguinh them from other similarly situated areas, and since the legie lation in question exempts certain dietricts from the operation of genernl lawe, the lepir Intion is both loenl and apecinl in chnrecter. and thus violative of acetions 59 and 60 of the Constitution of Eeatucly, therefore, the following sections are uneonetítutional loeni or opecial legialation in contravention of sec. tions 69 and 60 of the state conetitution: KR:S 154.45-001, 154.45-020, 154.45-030, this tion, 154A5-050, 154.15-070, and 154.46-090: furthermore, although Hous Bill 66. (Acte 1992, ch. 35) enacted by the 1992 Generel Anesmbly, make numerous changes to various provisions in the enterprive sose etatutes the Attornery Geseral's office did not find that it affected the conciusion of unconetitutionst. ity. OAG 9286.

154.45-050. Number of enterprise zones limited - Preferred areas - Etect of revocation - Retention of certification and eligibility for tax exemption after removal of designation. - (1) In addition to the seven (7) existing state enterprise zones, the authority may designate three (3) additional state enterprise rones by December 31, 1988. In deciding 
which areas should be designated as enterprise zones the authority shall give preference to:

-

(a) Local governments that have documented the greatest commitment to the goals established pursuant to KRS 154.45-001;

(b) Areas with the highest levels of poverty, unemployment, and general distress; and

(c) Areas that have the greatest support from the local government seeking designation, the community, residents, local business, and private organirations, taking into account the resources available to the local government.

(2) Designation of an area as an enterprise zone shall remain in effect during the period beginning on the date of designation and ending on $\mathrm{De}$ cember 31 of the twentieth year following designation.

(3) The authority shall remove the designation of an area as an enterprise zone if the area no longer meets the criteria for designation as set out in KRS 154.45-020 to 154.45-110 or by administrative regulation adopted by the authority pursuant to KRS 154.45-020 to 154.45-110. The authority shall establish by administrative regulation a procedure for revocation of the designation of an enterprise zone. The authority shall ensure that local governments shall be notified in writing of the authority's intent. and reasons for considering revocation of the designation. The authority shall establish a reasonable time frame within which the local government may correct the problems cited by the authority to avoid revocation of the enterprise zone designation.

(4) A local government that has had an enterprise zone designation revoked shall be prohibited from applying for future enterprise zone deaigna. tions for at least five (5) years. The authority may, by administrative regulation, extend the time frame that a local government is prohibited from participating in the enterprise zone program.

(5) If the authority revokes the designation of an enterprise zone, it ahall immediately begin reviewing the applications of local governments seeking an enterprise zone and designate a new area as an enterprise zone as soon as possible.

(6) If the authority removes the designation of an area as an enterprise zone pursuant to this section, the qualified businesses within the area ahall retain certification and shall remain eligible to receive tax exemptions pursuant to KRS 154.45-090 until December 31 of the twentieth year from the date of the original designation of the area as an enterprise zone. $=$ (Enact. Acts 1982, ch. 131, \& 5, effective July 15, 1982; 1986, ch. 30, \& 5, effective July 15, 1986; 1992, ch. 35, \& 6, effective July 14, 1992.)

Compilar's Notea. This section was for mexiy compiled as KRS 154.670.

Optnions of Attorney General Limitation of the benefits under the enterprise zoses program to ten areas selected by the enterpriee sone authority does in fnet confer a apecial status on these areas, denying benefits they receive to other areas aimilariy aituated; since unique benefits are provided to deaignated areas having no natural and reacoable basis to distinguish them from other cimilariy situnted areas, and aince tho legie. Lation in question exempte certain distriets from the operation of general lawe, the legis. lation is both local and apecial in character. and thus violative of rections 69 and 60 of the Conetitution of Kentucly; therefios. the following sections are uneonetitutional loeal or special legirlation in contravention of sectioss 59 and 60 of the etate conetitution: RaS 154.45-001, 184.45-020, 184A5-030, 154.45-040, thit rection, 154.45-070, and 154.45-090; furthermere, although Howe Bill 66. (Act 1992, ch. 35) enacted by the 1992 General Aseembly, matee numerven changes to various provisions in the enter pribe sose atatutes the Attorney General's of fice did not find that it affected the conciunion of unconititutionality. OAG 92-86. 
154.45-060. Enterprise Zone Authority of Kentucky - Member. ship - Terms - Meetings - Compensation - Staff. - (1) For the purposes of carrying out the provisions of KRS 154.45-020 to 154.45-110, there is hereby created the Enterprise Zone Authority of Kentucky consist ing of eleven (11) members. The authority shall be appointed as follows: one (1) member appointed by the Governor from a list of three (3) persons nominated by the Labor Management Advisory. Council; one (1) member appointed by the Governor from a list of three (3) persons nominated by the Kentucky League of Cities; one (1) member appointed by the Governor from a list of three (3) persons nominated by the Kentucky Association of Counties; one (1) member appointed by the Governor who is qualified to represent the interests of Kentucky's small business community; one (1) member appointed by the Governor from a list of three (3) persons nomi. nated by the AFL-CIO of Kentucky; two (2) members appointed by the Governor to serve at large; one (1) member appointed by the Governor from a list of five (5) persons nominated by the secretary of the Cabinet for Economic Development; the secretary of the Cabinet for Economic. Development or his designee; the secretary of the Revenue Cabinet or his deaigien; and the secretary of the Cabinet for Human Resources or his deaignea.

(2) Authority members shall serve a term of four (4) years and, except forthe secretary of the Cabinet for Economic Development, the secretary of the Revenue Cabinet, and the secretary of the Cabinet for Human Reeources, shall not be eligible to succeed themseives.

(3) The authority shall meet at least four (4) times per year. A majgrity of the total authority memberahip shail be required to deaignate an area as an enterprise zone and to certify businiesses as qualified busineseses. The authority shall keep official minutes of all meetings. All members shrll sarve until such time as their successors are qualified and appointed. Encti member of the authority shall receive one hundred dollars (\$100), not to exceed tweive hundred dollars $(\$ 1,200)$ per calendar year, as compensation for attending official meetings of the authority. Bach member of the anthority shall be reimbursed for travel expenses actually incurred in the discharge of his duties on the authority.

(4) The Cabinet for Economic Development shall serve as staff for the authority and carry out the administrative duties and functions as directed by the authority. (Enact. Acts 1982, ch. 131, \& 6, effective July 15, 1982; 1986, ch. 30, \& 6, effective July 15, 1986; 1992, ch. 35, \& 7, effective July 14, 1992.)

Compllare Notes. The proviaions of thi ection by whieh the Speatrer of the Houne of Representatives and the President Pro Tem of the Senter are made members of the $\mathrm{Ep}$ tirspries Zose Autherity were deciared unecen. titutionel in Legialative Resenreh Comm'n exel. Prather v. Brown, 664 8. W 2d 907 (KY. 1984).

This section was formecily compiled a IRS 184.675.

Ientueky Law Journal. Kentuely Iaw Survey, Whiteaida, Taration, 71 Ky. LW. 476 (1882-83).
Optnions of Atiorney Goneral Sines the members of the Enterprive Zone Antherity are etate officess they must exsecut the eath of ofice prescribed by Conet o 22.3. OAC $82-129$.

Sines the tarms of KRS 154.001 to 154.100 clearly indicate that members of the Buter

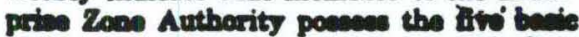
elements required in order to entablich thintr position as a public office and a tate cilis. the Governor eannot appoint county and eity officers to the authority without violating Coant of 168 and EDSS 61.080; thendions the 
In matucky municipal league and the Kento eseociation of counties must submit the

然

i.

T. Conetitutionality.

Statutes, such as this section, in which the epeaker of the House and the President Pro - 4 p.m of the Senate are made members of cerIlin boards, are invalid because such consti-

154.45-070. Duties of authority. - The authority shall administer the provisions of KRS 154.45-020 to 154.45-110, and shall:

(1) Establish by administrative regulation a process to monitor compliince by local governments and qualified businesses with the provisions of the Enterprise Zone Program; $\quad \therefore . . . . .4 \%$

(2) Initiate contact and fully cooperate with the Revenue.Cabinet in the collection of information to determine the fiscal impact of enterprise sone f tar exemptions on state revenues;

(3) Report to the General Assembly no later than October 1 annually regarding:

(a) The authority's method of monitoring the Enterprise Zone Program; ifor. (b) Information on the fiscal impact of enterprise zone tax exemptions on itate revenues;

(c) The authority's method of reviewing local incentives:

(d) Information on the number of qualified businesses per zone;

(e) Information on the number of requests for amendments to sone boundaries and the number of amendments granted and denied; and (f) Recommendations requiring state legislative action;

(4) Revoke designation of an area as an enterprise zone pursuant to the provisions of KRS 154.45-050.

(5) Prohibit the certification of businesses in an enterprise rone if the local government has been notified in writing by the authority of the anthority's intent to revoke the local government's designation as an enterprise zone. The prohibition of certification of businesses shall continue until the authority officially revokes the local government's enterprise zone derignation, or notifies the local government in writing that the problems cited by the authority have been corrected and the enterprise zone deaignation shall not be revoked;

(6) Offer technical assistance and job training assistance to local governments, qualified businesses, and neighborhood enterprise association corporations; and

(7) Aggresaively review local incentives and commitments on an annual basis. (Enact. Acts 1982, ch. 131, \& 7, effective July 15, 1982; 1986, ch. 30, \& 7, effective July 15, 1986; 1992, ch. 35, \& 8, effective July 14, 1992.)

Compilar's Notee This eection was formeriy compiled as KRS 154.680.

Fentucky Law Journal. Kentucky La Survey, Whiteaide, Taration, 71 KY. LN. 479 (1982-83).

- Oplnions of Attorney General. Limitatica of the benefits under the enterpries soses program to ten areas selected by the enterprise sone autherity does in fact confer a opecial statns on thees areas denying beavfite they receive to other areas aimilarty aitur. ated, since unique benefite are provided to deaignated areas having no natural and rear. consble banis to distinguish them from other similarly aitunted arean, and sines the locir lation in quention exempts certain dintrict from the operation of general lawn, the legit lation is both local and opecial in charneter, 
and thus violative of sections 59 and 60 of the Constitution of Kentucky; therefore, the following sections are unconstitutional local or special legislation in contravention of sections 59 and 60 of the state constitution: KRS 154.45-001, 154.45-020, 154.45-030, 154.45-040, 154.45-050, this section, and
154.45-090; furthermore, although Hown Bill 66, (Acts 1992, ch. 35) enseted by the: 1992 General Assembly, mates numerven changes to various provisions in the onten prise zone statutes the Attorney General's of fice did not find that it affected the conclusion of unconstitutionality. OAG 9286 .

154.45-080. Master business license. - (1) The authority shall estab. lish and design for public display a master business license that shall cen tify that the qualifying business has obtained all necessary state agency permits, licenses, certificates, approvals, registrations, charters, or an. other form of permission required by law to engage in business in an enter prise zone.

(2) The authority shall provide information and asaistance to permom desiring to locate and engage in business in an enterprise zone regarding. the state licenses, permits, certificates, approvals, registrations, charter. and any other forms of permission required by law to engage in businese the Commonwealth.

- (3) Responsibility for determining if requested licenses, permits, certin : cates, approvals, registrations, charters, or other form of permisaion rer; quired by law shall be issued to a qualified business, shall remain with ing agency legally authorized to issue the license. (Enact. Acts 1982, ch. 11:5 \& 8, effective July 15, 1982; 1986, ch. 30, \& 8, effective July 15, 1986; 199: ch. $35, \& 9$, effective July 14,1992 .)

Compilex's Notes This section was for merty compiled as KRS 154.685. 154.45-090. Tax advantages, credits, and exemptions for qualified: businesses. - (1) A new business, or an existing business certified on:th is basis of employee expansion, shall be eligible to receive the tax advanta 7 ? provided for in this section if the qualified business maintains the percedif age of targeted workforce employees required by KRS 154.45-010(7) for the entire time it is certified as a qualified business in the Enterprise Zotit Program.

(2) Building materials used in remodeling, rehabilitation, or new chith gtruction within an enterprise zone shall be exempt from sales and tares provided for in KRS Chapter 139.

(3) New and used equipment and machinery purchased and used hy qualified business within an enterprise rone shall be exempt from salti... use taxes provided for in KRS Chapter 139. Equipment and machinery ma? be moved in and out of an enterprise zone for business purposes only. If addition, it may not become a permanent fixture at another location and may be only temporarily located elsewhere for maintenance, mechanical failure, or emergency short term replacement.

(4) Commercial vehicles as defined in KRS 186.050, purchased and used by a qualified business solely for business purposes, shall be exempt from the motor vehicle usage tax imposed by KRS 138.460. , ... ...

(5) Motor vehicles not considered commercial vehicles pursurint to KRS 186.050, purchased and used by a qualified business solely for busine-1. purposes, shall be exempt from the motor vehicle usage tax limited to the first twenty thousand dollars $(\$ 20,000)$ of the "retail price" of the vehicle as defined in KRS 138.450 . 
16)

6) Motor vehicles or motor trucks purchased by a qualified business for the purpose of being leased to a customer for a period greater than ninety iO) days shall not be exempt from the motor vehicle usage tares provided for in KRS 138.460 .

14.(7) A qualified business shall be allowed a credit against the tax leviea pursuant to KRS 141.040 equal to ten percent (10\%) of wages paid to each amployee who has been unemployed for at least ninety $(90)$ days or who has recived public assistance benefits, based on need and intended to alleviate poverty, for at least ninety $(90)$ days prior to employment with the qualified business, up to fifteen hundred dollars $(\$ 1,500)$ per employee. Any unused crodit may be carried forward for up to five (5) years.

(8) A local government may, by an act of the local legislative body, lovy 5 . ad valorem tax rate of one-tenth of one cent (\$.001) upon each one hnndred dollars (\$100) of value on qualified property within an enterprise we regardless of the rates provided for in KRS Chapter 132. (Fnact. Acts 1982, ch. 131, \& 9, effective July 15, 1982; 1986, ch. 30, \& 9, efiective July 115, 1986; 1986, ch. 431; \& 8, effective July 15, 1986; 1988, ch. 118, \& 2 , effective July 15, 1988; 1992, ch. 35, \& 10, effective July 14, 1992.)

's.

* Compilex's Noter. This section was fors meriy compiled as KRS 154.690.

- Kentucky Bench Bar. Tobergte, The Impect of Kentuchy/s Present Constitution Upon Buninese Growth \& Development. Volfr... 61. No. 3, Summer 1987. KY. Bench \& Ber 21.

Bentrock Lav Journal Kentueky Law f gurvey, Whiteside, Taration, 71 KY. LN. 479 (19e2-83).

Opinions of Attorney Gemeral Limita.

filt of the besefits undes the enterpries

noes program to ten areas celocted by the

coterprise sone authority does in fiet confar a opecial status on theee areas, denying besefits they recaive to other areas aimilariy tito.

ot aince unique benefit are provided to

deaimated arees having no nntoural and rea.

inanablo basis to dintinguish them from other

sio

154.45-100. Neighborhood entarprine ansocintion corporation-. Istablishment - Certification - Lnind owned by state and loenl sop ferrments to be leaped to corporation - Tar exemption. I (1) Individuals reaiding in an enterprise cone may establish a neighborm hood enterprise association corporation. There shall be one (1) corporation! fir each geographic neighborhood area which shall be defined by the ineor. porating reaidents.

(2) The incorporating reaidents shall draft a charter and bylawe for the association suitable for doing business in corporate form. The charter and bylaws shall describe the geographic neighborhood area to which the incorporating association applies, the manner in which a stock intereot in the corporation shall be offered to each reaident of the neighborhood, contrin provisions for amendment by a majority of stochholders, and authorise the corporation to engage in business only within the particular zone in which the neighborthood area of the corporation is located.

5.: (3) The incorporating residents ahall send to:all residents of the corport. tion's neighborhood area: 
(a) An explanation of the proposed new corporation and their rights.in it:

(b) A copy of the corporate charter and bylaws; and

(c) An offer of the stock interest to which each particuiar resident is entitled without charge.

(4) The board of directors of the corporation may, upon approval of a majority of the members of the local legislative body of appropriate jurisdic. tion, apply to the authority for certification as a neighborhood enterprise association corporation. The authority shall not grant the status unless the corporation has complied with the requirements of this section and other requirements as may be adopted by the authority by administrative regula. tion. Upon granting certification, the authority shall place the corporation's charter and bylaws in a public file. The authority shall have power to revoke or suspend certification, or any of the leases issued under subsection (5) of this section, if the corporation fails to continue to comply with the requirements of this section. The authority shall give technical assistance to zone reaidents attempting to start corporations.

(5) Property within the neighborhood area of a certified corporation that is owned by the state or a local government and that is not in current use by the government shall be leased to the corporation. The term of the lease shall not be less than ninety-nine (99) years and the full amount of rental fees under the lease shall not exceed one dollar (\$1). The lease may be renewred upon expiration if the corporation has continuousiy complied with the requirements of this section.

(6) A certified corporation shall be exempt from state and local taration during the life of the zone in which it is located. (Enact. Acts 1982, ch. 131. 8 11, effective July 15, 1982; 1986, ch. 30, \& 11, efiective July 15, 1986; 1992, ch. 35, \& 11, effective July 14, 1992.)

Compilex's Notee This section was for mects compiled as KRS 154.700.

Kentroiks Law Journal Keatuchy Law
Survey, Whitedide, Taration, 71 KY. L.J. 470 (1982-83).

154.45-110. Duties of Revenue Cabinet - Report to General Asembly on fiscal impact of Enterprise Zone Program. - (1) The Rew nue Cabinet shall initiate contact and fully cooperate with the authority. in the collection of information to determine the fiscal impact of enterprise zone tar exemptions on state revenues.

(2) Report to the General Assembly no later than October 1 annually reganding:

(a) The cabinet's method of monitoring the Enterprise Zoine Program:

(b) Information on the fiscal impact of enterprise zone tax exemptions on state revenues; and

(c) Recommendations requiring state legislative action.

(3) The Revenue Cabinet shall by administrative reguintion amend its sales and use tax return to collect fiscal information on qualified businesses within an enterprise zone for purposes of reporting to the General Assembly.

(4) The Revenue Cabinet shall promulgate administrative regulations to establish a process for the collection of $\operatorname{tax}$ information relating to enterprise zone tax exemptions. (Enact. Acts 1986, ch. 30, \& 12, efiective July 15 , 1986; 1992, ch. 35, \& 12, effective July 14, 1992.) 
Compiler's Notes. This section was for-

perly compiled as KRS 154.705.

154.45-120. Cabinet for Human Resources to verify employmentinformation of qualified businesses. - The Cabinet for Human Rocources shall verify employment information relating to the hiring requirements of qualified businesses to select and maintain employees from thi targeted woricforce. The Cabinet for Human Resources shall fully cooperat with the authority in the development of a system to monitor employment information supplied by qualified businesses. (Enact. Acts 1992, ch. 35; 13, effective July 14, 1992.)

\section{Subchapter 50. Industrinl Development:}

15450-020. Legislative findings of fact - Purpose of KRS $15450-020$ to $154.50-030$. - (1) It is hereby found, determined, and doclared as a legislative finding of fact that the general welfare of the citisens of the Commonwealth is directly related to the economic and emplosment opportunities available to them, and it is the legitimate business of the Kentucky state government to provide to the maximum extent practicable, the impetus for and assistance to economic development in the Commonwealth through the provision of monetary assistance to industrial entrities for industrial improvement projects which will directly and prorimately cause the improvement and retention of industry and employment in the Commonwealth.

(2) It is hereby further found, determined, and declared as a legisiative finding of fact that the improvement and retention of manufactoring, procosaing, and assembling facilities will procimately result in:

(a) The creation or retention of employment opportunities; or

(b) The creation or retention of tax revenues to the Commonwealth, as a taring entity, which would not be available to the citizens of the Common. wealth or received by the Commonwealth but for the improvement and retention of the facilities and which creation or retention of employment opportunities or tax revenues are hereby found, determined and declared to constitute receipt of value by the Commonvrealth for the monetary aniftance which it may provide pursuant to KRPS 154.50-020 to 154.50-050 to industrial entities undertaking industrial improvement projects located in this state.

(3) It is the purpose of KRS $154.50-020$ to $154.50-030$ to promote and forter the gainful employment, business, and economic development opportunities and general welfare of the citivens and residents of the Commonwealth which will reoult in the alleviation or prevention of unomployment and the general stability of the economy of Kentucky. This purpoes will be accomplished by the creation of the authority to enable the Commonwealth to provide monetary asaistance to industrial entities, for the improvement : and retention of industrial manufacturing, processing, or assembling facilities in the Commonwealth which, in return, will create or retain employment opportunities for citizens of the Commonwealth or will create or rotain tar revenues. The authority granted by KRS $154.50-020$ to $154.50-030$ and the purposes to be accomplished by KRS 154.50-020 to $154.50-030$ are hereby declared to be public purposes for which public money may be expended. (Fnact. Acts 1990, ch. 306, \& 2, efiective July 13, 1990.) 
VITA

Thomas E. Lambert was born in Louisville, Kentucky on December 10, 1959. He attended St. Denis Catholic Grade School and graduated from Bishop David High School in June, 1977. He then received a B. A. with Honors from the University of Louisville in December 1980, and later earned a M. B. A. from the University of Louisville in August, 1986. While working for the University of Kentucky Community College System, he received a M. S. in Economics from the University of Kentucky in August, 1993.

Over the years he has taught classes in business management, economics, and remedial mathematics at the University of Louisville, Jefferson Community College, and Indiana University Southeast.

In his final year of graduate studies, he served as Vice-President of the University's Graduate Student Council as well as a Senator in the University's Student Government Association.

He plans a career in either academia or public administration after completing his duties as a Graduate Research Assistant at the University of Louisville. 